\title{
Air Emissions Inventory for the Idaho National Engineering and Environmental Laboratory Calendar Year 1998 Emissions Report
}

S. K. Zohner

October 1999 


\section{DISCLAIMER}

This report was prepared as an account of work sponsored by an agency of the United States Government. Neither the United States Government nor any agency thereof, nor any of their employees, make any warranty, express or implied, or assumes any legal liability or responsibility for the accuracy, completeness, or usefulness of any information, apparatus, product, or process disclosed, or represents that its use would not infringe privately owned rights. Reference herein to any specific commercial product, process, or service by trade name, trademark, manufacturer, or otherwise does not necessarily constitute or imply its endorsement, recommendation, or favoring by the United States Government or any agency thereof. The views and opinions of authors expressed herein do not necessarily state or reflect those of the United States Government or any agency thereof. 


\section{DISCLAIMER}

Portions of this document may be illegible in electronic image products. Images are produced from the best available original document. 


\begin{abstract}
This report presents the 1998 calendar year update of the Air Emission Inventory for the Idaho National Engineering and Environmental Laboratory (INEEL). The INEEL Air Emission Inventory documents sources and emissions of nonradionuclide pollutants from operations at the INEEL. The report describes the emission inventory process and all of the sources at the INEEL, and provides nonradionuclide emissions estimates for stationary sources.
\end{abstract}




\section{SUMMARY}

During the fall of 1989, the Air Emission Inventory (AEI) was initiated at the Idaho National Engineering and Environmental Laboratory (INEEL) as a result of the Environmental Oversight and Monitoring Agreement between the State of Idaho and the Department of Energy Idaho Field Office, and a request from the Idaho Division of Environmental Quality. The AEI documents sources and specified emissions of nonradionuclide pollutants at the INEEL. The AEI report summarize (for specified pollutants) individual emissions and grouped emissions to show the INEELs total emissions.

The AEI is updated annually to reflect the previous year's emissions, changes in operating sources, and inventory refinements. The current update of the AEI data reflects calendar year 1998 (CY-1998) operations. The AEI System, an ORACLE-based database system, maintains the emissions inventory. The INEEL contractors and their associated facilities provide information to the AEI System to reflect annual operations. The annual update of information is utilized to calculate air emissions for the INEEL.

The inventory presently maintains approximately 10,500 vents, and of those vents, approximately 650 are possible emission sources. Emission source types range from conventional fuel combustion and storage sources to nuclear reactor and research facility exhausts. The AEI System uses the U.S. Environmental Protection Agency's (EPA) Compilation of Air Pollutant Emission Factors (AP-42) calculations to estimate emissions for many of the general sources. The air contaminants reported include nitrogen oxides, sulfur oxides, carbon monoxide, volatile organic compounds, particulates, hazardous air pollutants (HAPs), trace elements, polynuclear aromatic hydrocarbons (PAH), speciated organic compounds and various organic compounds.. Primary nonradionuclide emissions from sources at the INEEL for 1998 are presented in the table below.

A listing of all the significant and not significant emission sources are provided for each area at the INEEL. The AEI is now individually reporting only those sources that have a specified emission limit associated with them. Those sources that do not have a related emission limit are identified and grouped according to various categories. The emissions associated with each group at the INEEL are estimated and discussed. The summation of the emissions from the individual sources and the INEEL groups provide the total INEEL emission estimates. These descriptions and methodologies are discussed in Sections 3 and 4. 
Table 1. Summary of emissions greater than 5 pounds at the REEL for calendar year 1998.

\begin{tabular}{|c|c|c|}
\hline Chemical & ton/yr & $\mathrm{lb} / \mathrm{yr}$ \\
\hline Nitrogen oxides & $5.4 \mathrm{E}+02$ & $1,086,613$ \\
\hline Carbon monoxide & $2.8 \mathrm{E}+02$ & 569,708 \\
\hline Sulfur oxides & $1.8 \mathrm{E}+02$ & 362,414 \\
\hline VOCNM & $5.1 E+01$ & 101,485 \\
\hline PM-10 & $3.2 \mathrm{E}+01$ & 63,608 \\
\hline Nitric acid & $2.2 E+01$ & 44,000 \\
\hline VOC-methane & $1.1 E+01$ & 22,000 \\
\hline Carbon tetrachloride & $2.7 \mathrm{E}+00$ & 5,400 \\
\hline Hydrochloric acid & $2.0 \mathrm{E}+00$ & 4,000 \\
\hline 1,1,1-Trichloroethane & $2.0 \mathrm{E}+00$ & 3,930 \\
\hline Total Organic Compounds & $4.0 \mathrm{E}-01$ & 800 \\
\hline Chloroform & $1.0 \mathrm{E}-01$ & 200 \\
\hline Formaldehyde & $9.9 \mathrm{E}-02$ & 197 \\
\hline Lead & $8.0 \mathrm{E}-02$ & 160 \\
\hline Methyl alcohol & $7.0 \mathrm{E}-02$ & 140 \\
\hline Methylene chloride & $7.0 \mathrm{E}-02$ & 139 \\
\hline Propylene & $7.0 \mathrm{E}-02$ & 139 \\
\hline Trichloroethylene & $6.7 \mathrm{E}-02$ & 134 \\
\hline Toluene & $4.0 \mathrm{E}-02$ & 80 \\
\hline VOC vapors & $4.0 \mathrm{E}-02$ & 80 \\
\hline Benzene & $2.9 \mathrm{E}-02$ & 59 \\
\hline Magnesium & $2.8 \mathrm{E}-02$ & 56 \\
\hline Mercury & $2.4 \mathrm{E}-02$ & 48 \\
\hline Hexane & $2.3 \mathrm{E}-02$ & 46 \\
\hline Chromium & $1.2 \mathrm{E}-02$ & 25 \\
\hline Acetone & $1.0 \mathrm{E}-02$ & 20 \\
\hline Hydrofluoric acid & $1.0 \mathrm{E}-02$ & 20 \\
\hline Xylene & $8.0 \mathrm{E}-03$ & 16 \\
\hline Cyanide & $6.5 \mathrm{E}-03$ & 13 \\
\hline Acetaldehyde & $6.5 \mathrm{E}-03$ & 13 \\
\hline Manganese & $4.3 \mathrm{E}-03$ & 8.5 \\
\hline Nickel & $4.2 \mathrm{E}-03$ & 8.4 \\
\hline Selenium & $4.0 \mathrm{E}-03$ & 7.9 \\
\hline Naphthalene & $3.1 \mathrm{E}-03$ & 6.1 \\
\hline Cadmium & $2.5 \mathrm{E}-03$ & 5.0 \\
\hline
\end{tabular}


Principle Chemical

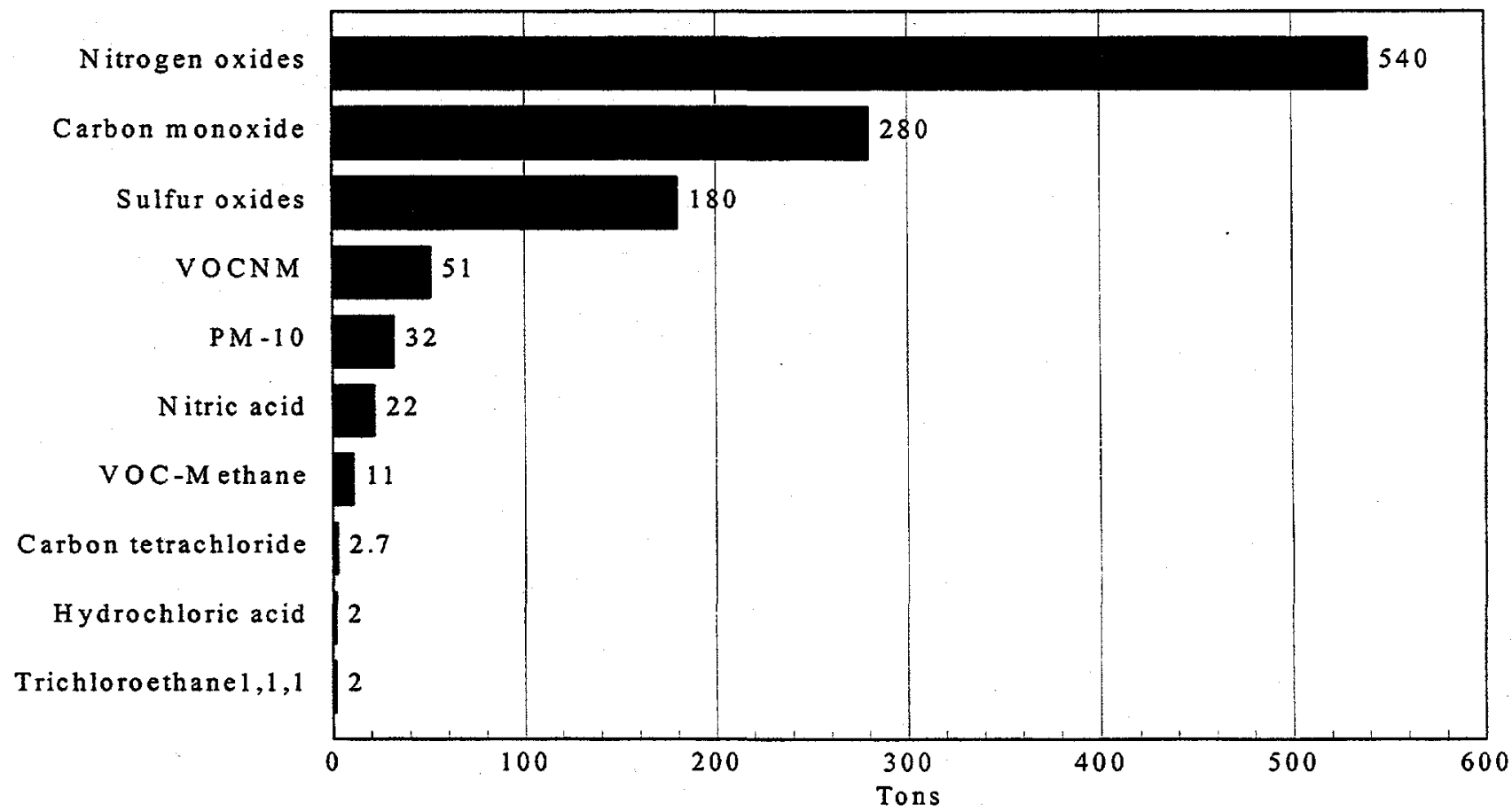

Chemical

Carbon tetrachloride Hydrochloric acid

Trichloro ethane $1,1,1$

TOC

Chloroform

Form aldehyde Lead

Methyl alcohol Methylene Chloride

Propylene

Trichloroethylene

Toluene

VOC vapors

Benzene

Magnesium

Mercury

Hexane

Chromium

Acetone

Hydrofluoric acid

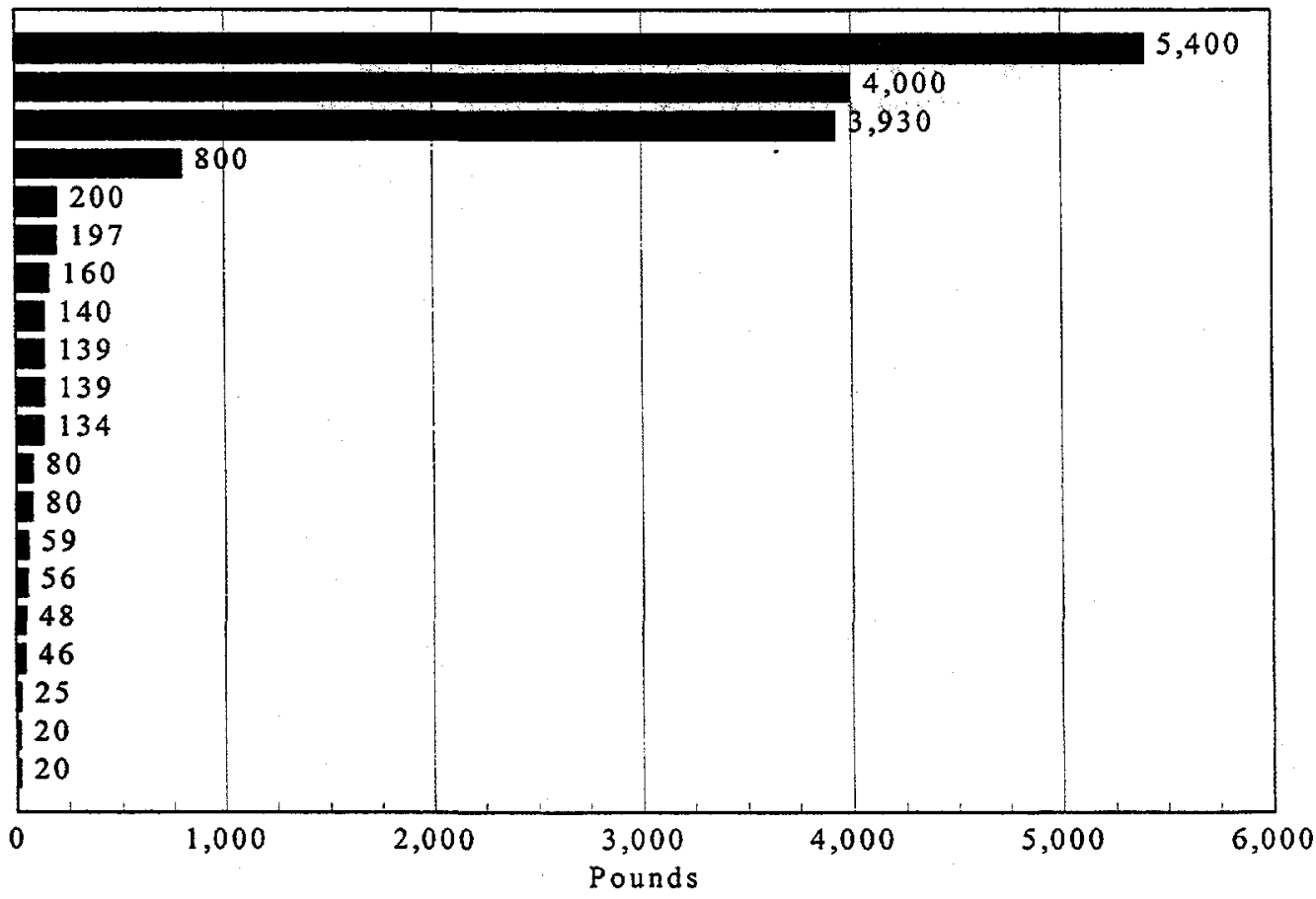

Figure 1. Summary of major INEEL emissions for 1998 greater than 20 pounds. 
Some of the more notable differences in the 1998 AEI compared to the 1997 AEI are as follows:

1. The INTEC New Waste Calciner was operational from January through mid-April. The 1998 AEI will show decreased emissions of $\mathrm{NO}_{\mathrm{X}}, \mathrm{VOC}$-nonmethane and nitric acid from 1997 when the Calciner operated for half the year. The VOC-nonmethane emissions are mostly (over $99 \%$ ) from the kerosene fuel used at the Calciner.

2. For 1998 calculations for engines and boilers used emission factors found in the current edition of AP-42, Compilation of Air Pollutant Emission Factors, EPA. This change has resulted in the addition of metals, speciated organic compounds and various other organic compounds to the list of emitted pollutants. Speciate factors were still used for some emissions in engines and boilers due to a technical coordination oversight.

3. Coordination with other INEEL emission reports is an ongoing feature of the AEI. Difficulties arise where specific emission reports meet various regulatory requirements. This is the case with the EPCRA report. Considerable effort has been given to review these emission reports and coordinate emissions estimates whenever possible.

4. The AEI does not include emissions from the following sources: mobile equipment (cars, buses), ozone depleting substances, landfarming (VOC), sewage and sewage treatment, drinking water (chlorine, demineralizer and ion exchange treatments). Detailed information on sources that are not reported may be found in section "2.7 Exempt Insignificant Activities".

5. For the first time small portable fuel burning equipment emissions are included in this emission report.

6. Landfill emissions were included in this years AEI. 


\section{ACKNOWLEDGEMENTS}

This year, the Air Emission Inventory Report was the result of the cumulative effort of various people and the contractors at the Idaho National Engineering and Environmental Laboratory: Argonne National Laboratory West; Lockheed Martin Idaho Technologies; and Bechtel Bettis, Incorporated. Special thanks are made to the Area Specific Coordinators for their diligence in supporting the inventory process. 


\section{CONTENTS}

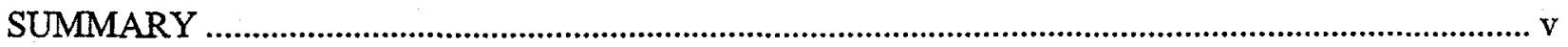

1. INTRODUCTION

2. AIR EMISSION INVENTORY PROCESS................................................................................. 3

2.1 Air Emission Inventory Phase I ....................................................................................... 3

2.1.1 Acquisition of Existing Data..................................................................................... 3

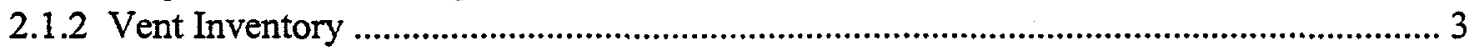

2.1.3 Vent Classification................................................................................................. 3

2.1.4 Existing Permits ................................................................................................... 4

2.2 Air Emission Inventory Phase II ............................................................................................ 4

2.3 Air Emission Inventory Phase III............................................................................................. 7

2.4 Air Emission Inventory Annual Update................................................................................. 7

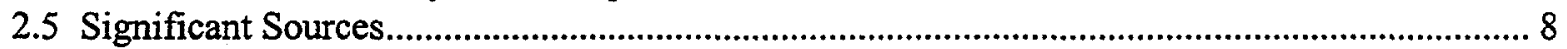

2.6 Not Significant Sources.................................................................................................................. 8

2.7 Exempt Insignificant Sources ............................................................................................ 10

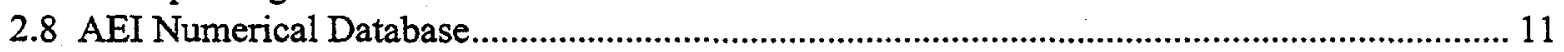

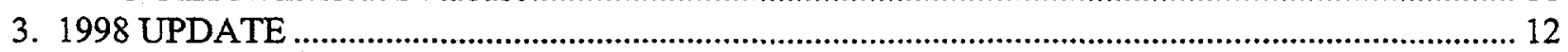

3.1 INEEL Site-wide Changes ............................................................................................... 12

3.2 Argonne National Laboratory-West.................................................................................. 13

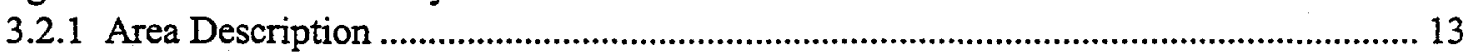

3.2.2 Significant Source Descriptions ..................................................................................... 13

3.2.2.1 Emergency/Standby Equipment................................................................................ 13

3.2.2.2 Diesel Fuel Storage Tanks ....................................................................................... 13

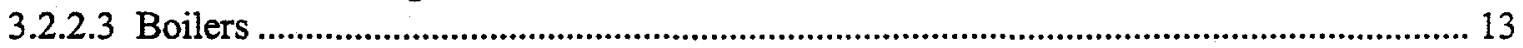

3.2.2.4 Fuel Conditioning Facility .......................................................................................... 15

3.2.2.5 Paint Booth............................................................................................................ 15

3.2.3 Not Significant Sources..................................................................................... 15

3.2.4 Summary of ANL-W Emissions ................................................................................ 17

3.2.5 Summary of ANL-W Changes.......................................................................... 18

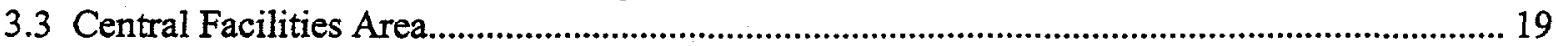

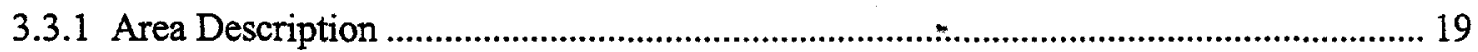

3.3.2 Significant Sources............................................................................................... 20

3.3.3 Not Significant Sources............................................................................................ 23

3.3.4 Summary of CFA Emissions................................................................................ 28

3.3.5 Summary of CFA Changes ................................................................................ 28

3.4 Idaho Nuclear Technology and Engineering Center ............................................................ 30

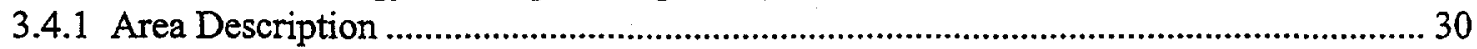

3.4.2 Significant Source Description ............................................................................... 32

3.4.3 Not Significant Sources............................................................................................. 34

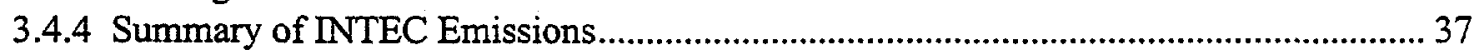

3.4.5 Summary of INTEC changes ........................................................................................ 38

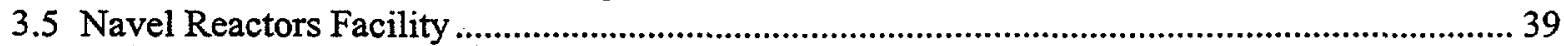

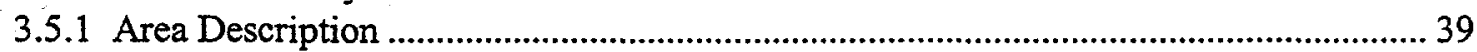

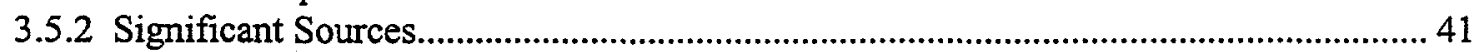

3.5.3 Not Significant Sources......................................................................................... 41

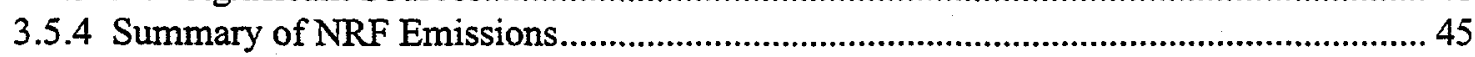




\section{CONTENTS}

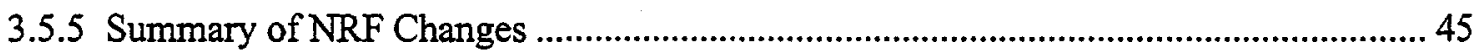

3.6 Power Burst Facility ......................................................................................................... 47

3.6.1 Area Description .................................................................................................. 47

3.6.2 Significant Source Descriptions..................................................................................... 54

3.6.3 Not Significant Sources............................................................................................. 55

3.6.4 Summary of PBF Emissions .................................................................................. 56

3.6.5 Summary of PBF Changes ......................................................................................... 57

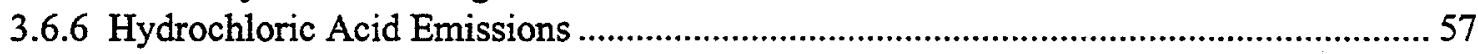

3.7 Radioactive Waste Management Complex .................................................................................5 58

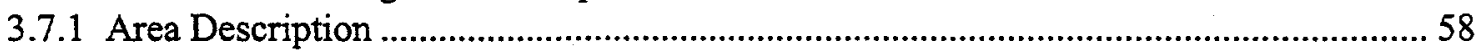

3.7.2 Significant Source Descriptions.................................................................................. 58

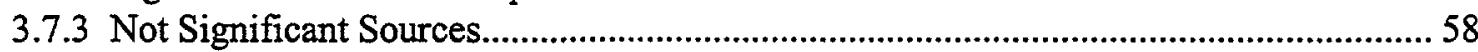

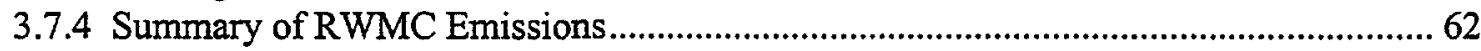

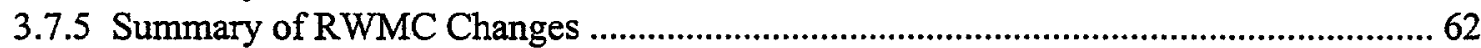

3.7.6 Carbon Tetrachloride and Trichloroethane Emissions ...................................................63

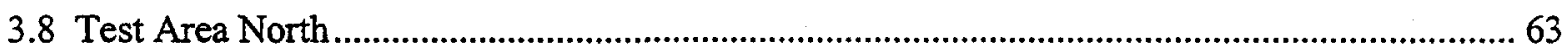

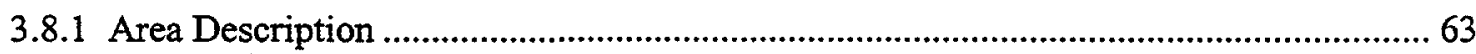

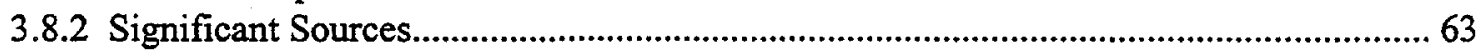

3.8.3 Not Significant Sources................................................................................................... 69

3.8.4 Summary of TAN Emissions ...................................................................................... 71

3.8.5 Summary of TAN Changes.................................................................................. 72

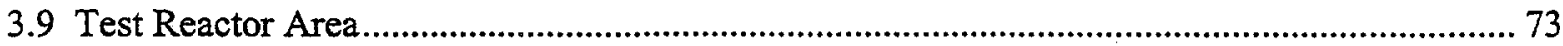

3.9.1 Area Description .................................................................................................. 73

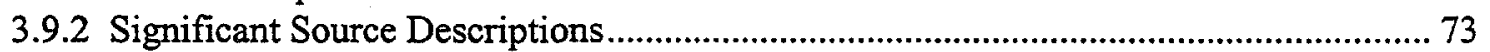

3.9.3 Not Significant Sources...................................................................................... 74

3.9.4 Summary of TRA Emissions ............................................................................. 77

3.9.5 Summary of TRA Changes …………………………............................................. 78

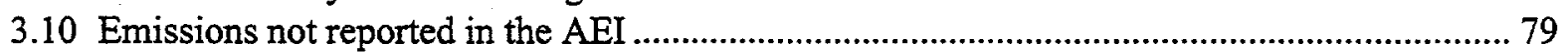

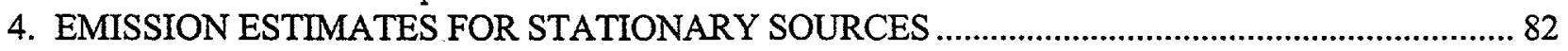

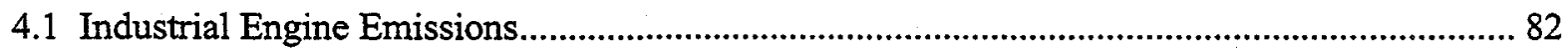

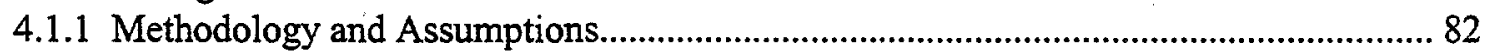

4.1.2 Calculations Performed by the Database ....................................................................... 83

4.1.3 LMITCO Grouped Sources...................................................................................... 83

4.1.4 Emission Estimates for Non Boiler Fuel Burning Grouped Sources.............................. 84

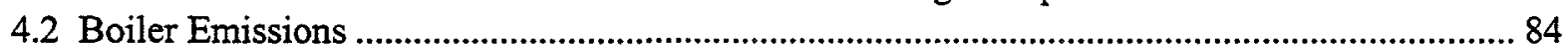

4.2.1 Methodology and Assumptions.................................................................................... 84

4.2.2 Calculations Performed by the Database …………….................................................... 86

4.3 Propane Burning Equipment .................................................................................................... 86

4.4 Laboratory Fumehood Calculations ..................................................................................... 87

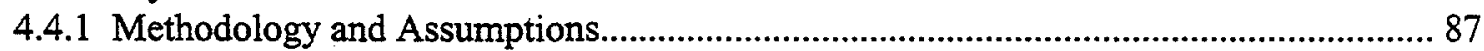

4.5 Organic Tank Emissions Calculations Methodology .......................................................... 88

4.5.1 Methodology and Assumptions............................................................................ 88

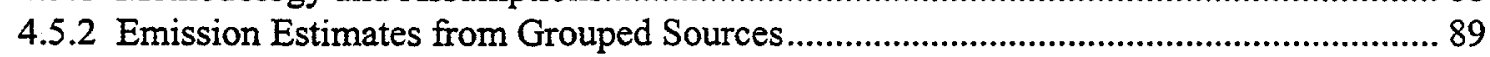

4.6 Painting Operations Calculations ..................................................................................... 90

4.6.1 Methodology and Assumptions................................................................................ 90

4.6.2 Grouped Painting Sources....................................................................................... 91 


\section{CONTENTS}

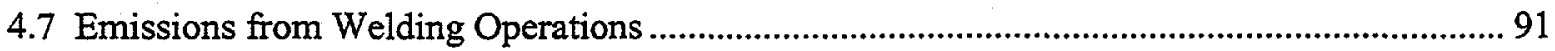

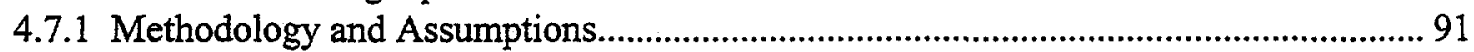

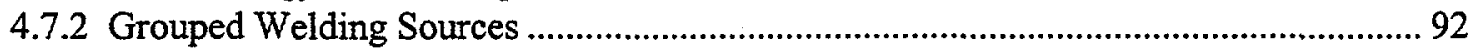

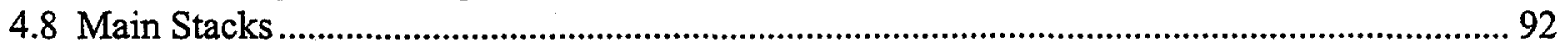

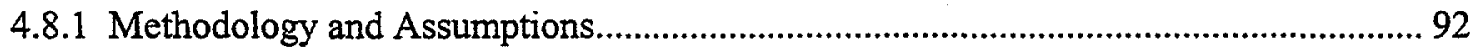

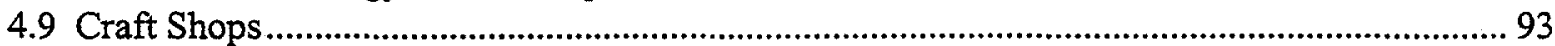

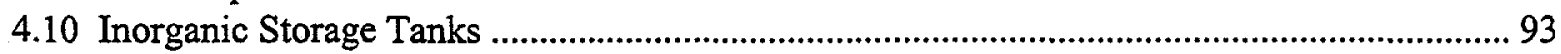

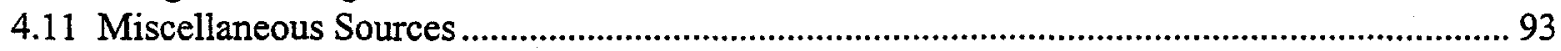

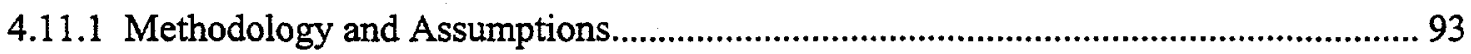

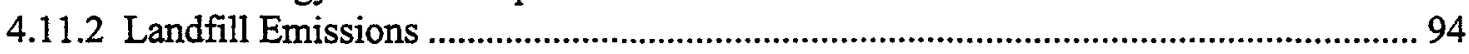

4.11.3 Emissions Reported Under Federal Regulations .................................................... 94

4.12 Hazardous Air Emissions For The INEEL .............................................................................. 95

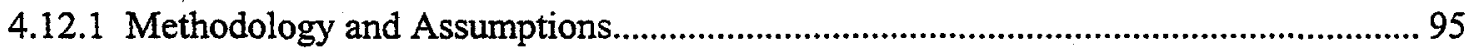

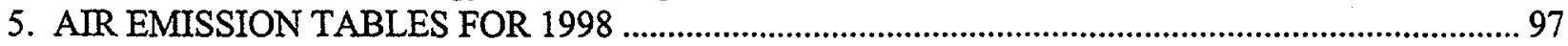

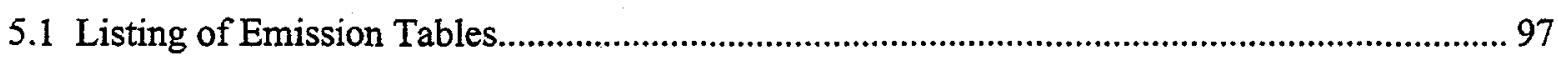

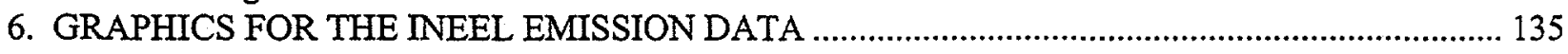

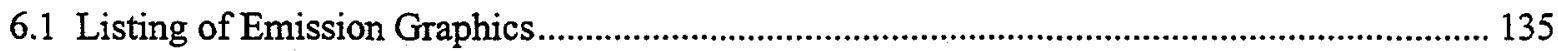

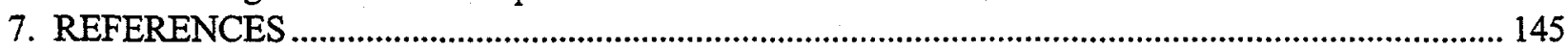

Appendix A Hazardous Air Pollutant List ............................................................................................. A 


\section{FIGURES}

1. Summary of major INEEL emissions for 1998 greater than 20 pounds............................................ vii

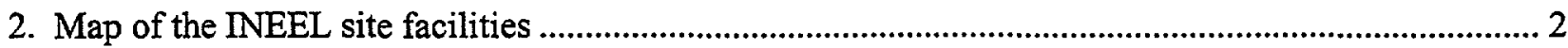

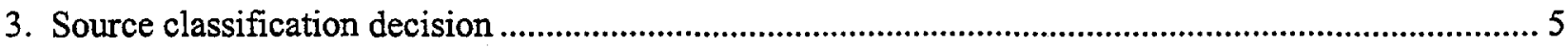

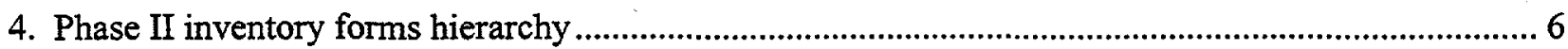

5. Area plot plan of Argonne National Laboratory West...................................................................... 14

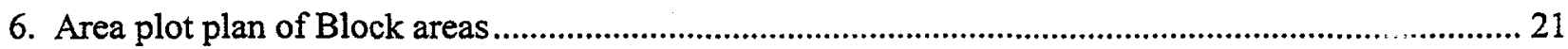

7. Area plot plan of the Central Facilities Area ...................................................................................... 22

8. Area plot plan of the Idaho Nuclear Technology and Engineering Center.......................................... 31

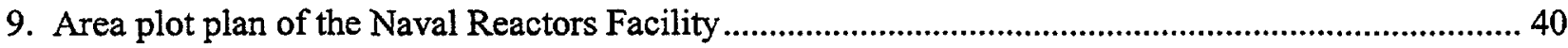

10. Area plot plan of the Power Burst Facility.................................................................................... 48

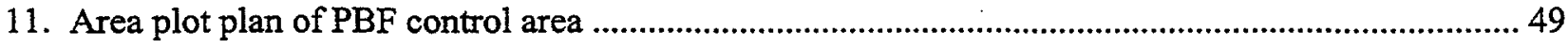

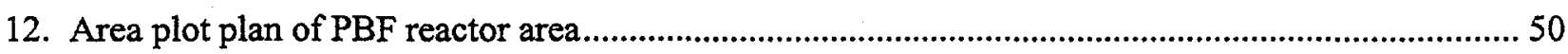

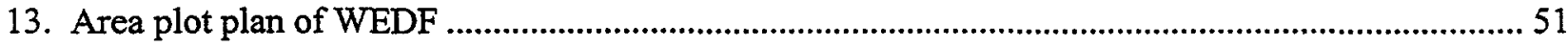

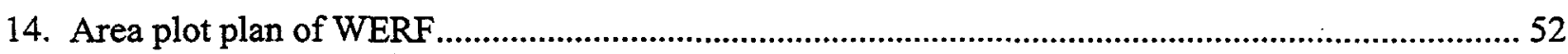

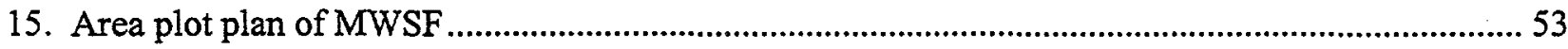

16. Area plot plan of the Radioactive Management Complex ............................................................. 61

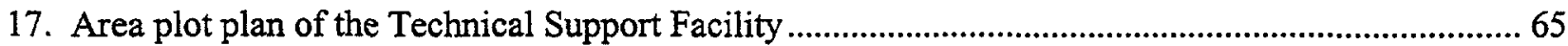

18. Area plot plan of Loss of Fluid Test and Specific Manufacturing Capability Area .......................... 66

19. Area plot plan of Water Reactor Research Test Facility ............................................................67

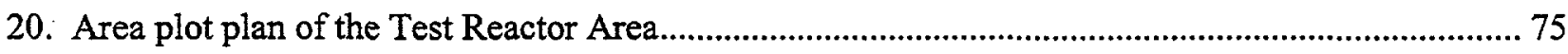

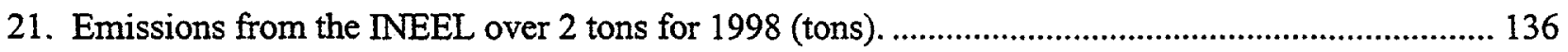

22. Emissions from the INEEL from 100 to 6,000 pounds........................................................... 137

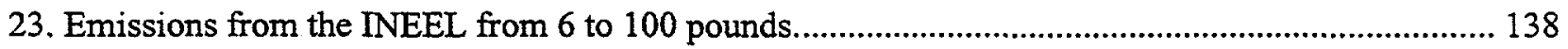

24. Emissions from the INEEL from 0.80 to 6 pounds....................................................................... 139

25. Emissions from the INEEL from 0.1 to 0.8 pounds................................................................... 140

26 Emissions from the INEEL from 0 to 0.1 pound....................................................................... 141

27 Metal emissions from the INEEL for 1998 (pounds). ............................................................ 142

28 Emissions from small portable engines for 1998 (pounds). ........................................................ 143 


\section{TABLES}

1. Summary of emissions greater than 5 pounds at the INEEL for calendar year 1998 ......................... vi

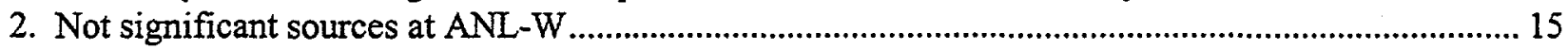

3. Summary of nonradionuclide principal pollutants at ANL-W .............................................................. 17

4. Summary of changes from 1997 to 1998 Air Emission Inventory Report ........................................ 18

5. Significant nonradiological air emission sources at CFA ........................................................... 23

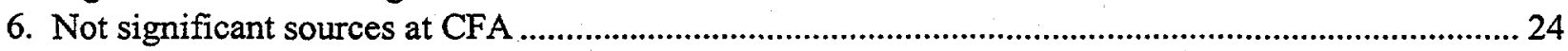

7. Summary of nonradionuclide principal pollutants at CFA ........................................................... 28

8. Summary of source changes at CFA -1997 to 1998 inventory .......................................................29

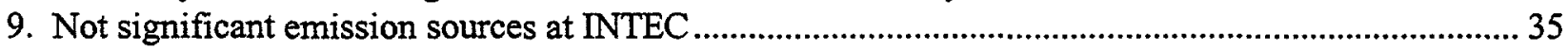

10. Summary of nonradionuclide principle pollutants at INTEC .......................................................... 38

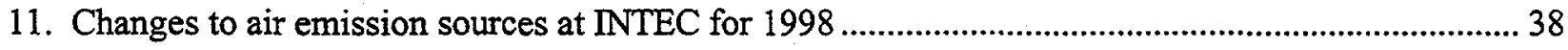

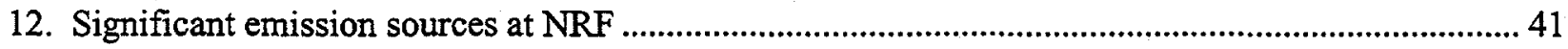

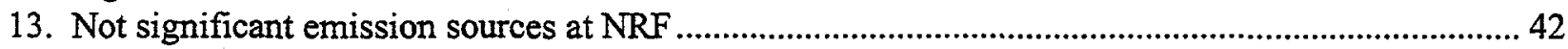

14. Summary of nonradionuclide pollutants from all sources at NRF ............................................45

15. Not significant sources at the Power Burst Facility areas...............................................................5

16. Summary of nonradionuclide principle pollutants at PBF ............................................................5 57

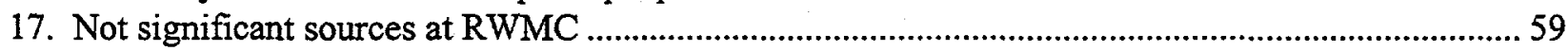

18. Summary of nonradionuclide principal pollutants at RWMC ......................................................62 62

19. Summary of source changes at RWMC - 1997 to 1998 inventory ..................................................62

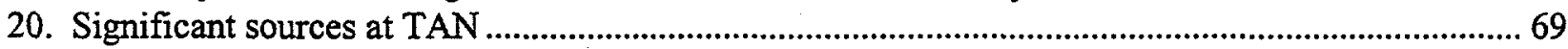

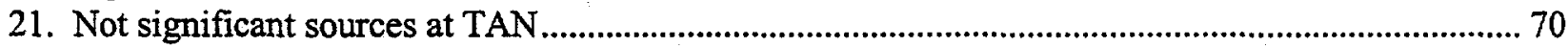

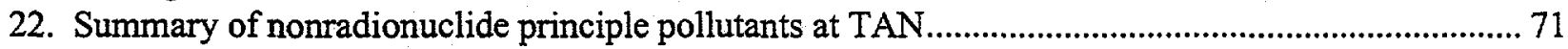

23. Summary of source changes at TAN - 1997 to 1998 inventory ….................................................. 72

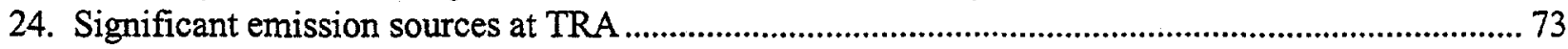

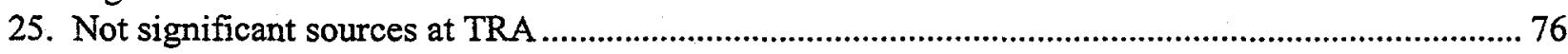

26. Summary of nonradionuclide principle pollutants at TRA ......................................................... 78

27. Summary of source changes at TRA - 1997 to 1998 inventory .................................................... 78

28. Emissions reported under EPCRA regulatios for the INEEL during 1998..................................... 94

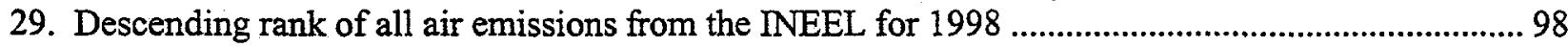

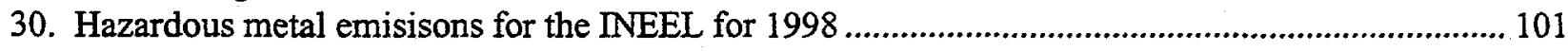

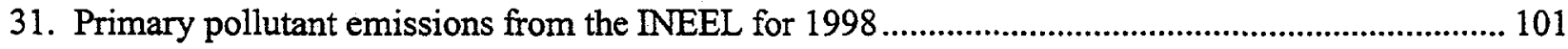

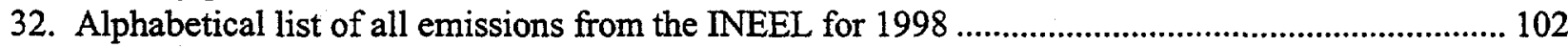

33. Summary of principle pollutant emissions from the INEEL for 1998......................................... 105

34. Summary of each principle pollutant by area for 1998 ........................................................... 107

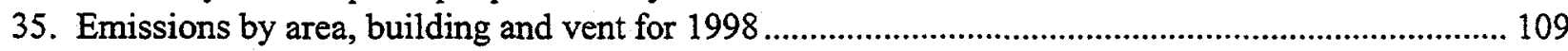

36. Descending rank of emissions for principle pollutants by area, building and vent ....................... 125

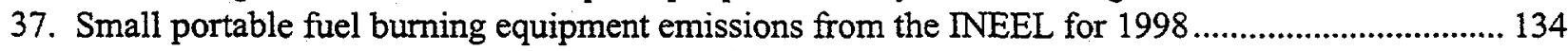





\section{ACRONYMS}

\begin{tabular}{|c|c|}
\hline A1W & NRF Large Ship Reactor \\
\hline $\mathrm{AEI}$ & Air Emission Inventory \\
\hline AFSR & Argonne Fast Source Reactor \\
\hline ANL-W & Argonne National Laboratory - West \\
\hline $\mathrm{AOP}$ & $\begin{array}{l}\text { Application for a Title V Operating Permit for the Idaho National Engineering and } \\
\text { Environmental Laboratory }\end{array}$ \\
\hline APAD & Air Permitting and Applicability Determination \\
\hline AP-42 & EPA Compilation of Air Pollutant Emission Factors \\
\hline ARA & Auxiliary Reactor Area \\
\hline AST & Above ground Storage Tank \\
\hline ATR & Advanced Test Reactor \\
\hline BER & Basic emission rate \\
\hline Bldg & Building \\
\hline BORAX & Boiling Water Reactor Experiment \\
\hline $\mathrm{BRC}$ & Below regulatory concem \\
\hline Btu & British thermal unit \\
\hline $\mathrm{CAA}$ & Clean Air Act \\
\hline CAS & Chemical Abstract Service \\
\hline CFA & Central Facilities Area \\
\hline $\mathrm{cfm}$ & Cubic feet per minute \\
\hline CFR & Code of Federal Regulations \\
\hline CFSGF & Coal-Fired Steam-Generating Facility \\
\hline $\mathrm{CH}$ & Contact handled \\
\hline $\mathrm{Ci}$ & Curie \\
\hline CY & Calendar year \\
\hline DEQ & Division of Environmental Quality \\
\hline DOE & Department of Energy \\
\hline DOE-ID & Department of Energy Idaho Field Office \\
\hline $\mathrm{EB}$ & East Butte \\
\hline EBR-I & Experimental Breeder Reactor I \\
\hline EBR-II & Experimental Breeder Reactor II \\
\hline ECF & NRF Expended Core Facility \\
\hline EDG & Emergency diesel generator \\
\hline EPA & Environmental Protection Agency \\
\hline EPCRA & $\begin{array}{l}\text { Emergency Planning and Community Right-to-Know Act of 1986, also known as Title III of } \\
\text { the Superfund Amendments and Reauthorization Act (SARA) }\end{array}$ \\
\hline ER & Emission rate \\
\hline ETR & Engineering Test Reactor \\
\hline FAST & Fluorinel Dissolution Process and Fuel Storage \\
\hline Fac & Facility \\
\hline FCF & Fuel Conditioning Facility \\
\hline FMF & Fuel Manufacturing Facility \\
\hline
\end{tabular}




\section{ACRONYMS}

$\begin{array}{ll}\text { gal } & \text { Gallon } \\ \text { gr } & \text { grain (equal to 0.0648 grams) } \\ \text { HAP } & \text { Hazardous air pollutant } \\ \text { HEPA } & \text { High-efficiency particulate air } \\ \text { HFEF } & \text { Hot Fuel Examination Facility } \\ \text { hp } & \text { Horse power } \\ \text { HPIL } & \text { Health Physics Instrument Laboratory } \\ \text { HVAC } & \text { Heating ventilation and air conditioning } \\ \text { HPTF } & \text { Howe Peak Transformer Facility } \\ \text { CPP } & \text { Chemical Processing Plant used to designate buildings at INTEC } \\ \text { ICPP } & \text { Idaho Chemical Processing Plant (has been changed to INTEC) } \\ \text { IDAPA } & \text { Idaho Administrative Procedures Act } \\ \text { IET } & \text { Initial Engine Test } \\ \text { IFR } & \text { Integral Fast Reactor } \\ \text { INEEL } & \text { Idaho National Engineering and Environmental Laboratory } \\ \text { INTEC } & \text { Idaho Nuclear Technology and Engineering Center (formerly ICPP) } \\ \text { kW } & \text { Kilowatt } \\ \text { LDHR } & \text { Long Term Decay Heat Removal } \\ \text { LMITCO } & \text { Lockheed Martin Idaho Technologies Company } \\ \text { LNG } & \text { Liquid Natural Gas } \\ \text { LOFT } & \text { Loss of Fluid Test } \\ \text { MCR } & \text { Maximum continuous rating } \\ \text { MDF } & \text { Material Development Facility } \\ \text { MBtu } & \text { Million British thermal units } \\ \text { MTR } & \text { Materials Testing Reactor } \\ \text { MW } & \text { Megawatt } \\ \text { MWSF } & \text { Mixed Waste Storage Facility } \\ \text { NESHAP } & \text { National Emission Standards for Hazardous Air Pollutants } \\ \text { NNRS } & \text { Newport News Reactor Services } \\ \text { NOAA } & \text { National Oceanic and Atmospheric Administration } \\ \text { NOX } & \text { Nitrogen oxides } \\ \text { NRF } & \text { Naval Reactors Facility } \\ \text { NWCF } & \text { New Waste Calcining Facility } \\ \text { PAH } & \text { polynuclear aromatic hydrocarbons } \\ \text { PBF } & \text { Power Burst Facility } \\ \text { PCB } & \text { Polychlorinated biphenyl } \\ \text { PER } & \text { Power Excursion Reactor } \\ \text { PM-10 } & \text { Particulate matter with aerodynamic diameter of 10 micrometers } \\ \text { PRF } & \text { Process Reclamation Facility } \\ \text { PSD } & \text { Prevention of significant deterioration (State of Idaho air quality permit) } \\ \text { psi } & \text { Pounds per square inch } \\ \text { PSU } & \text { Power system upgrade } \\ & \end{array}$




\section{ACRONYMS}

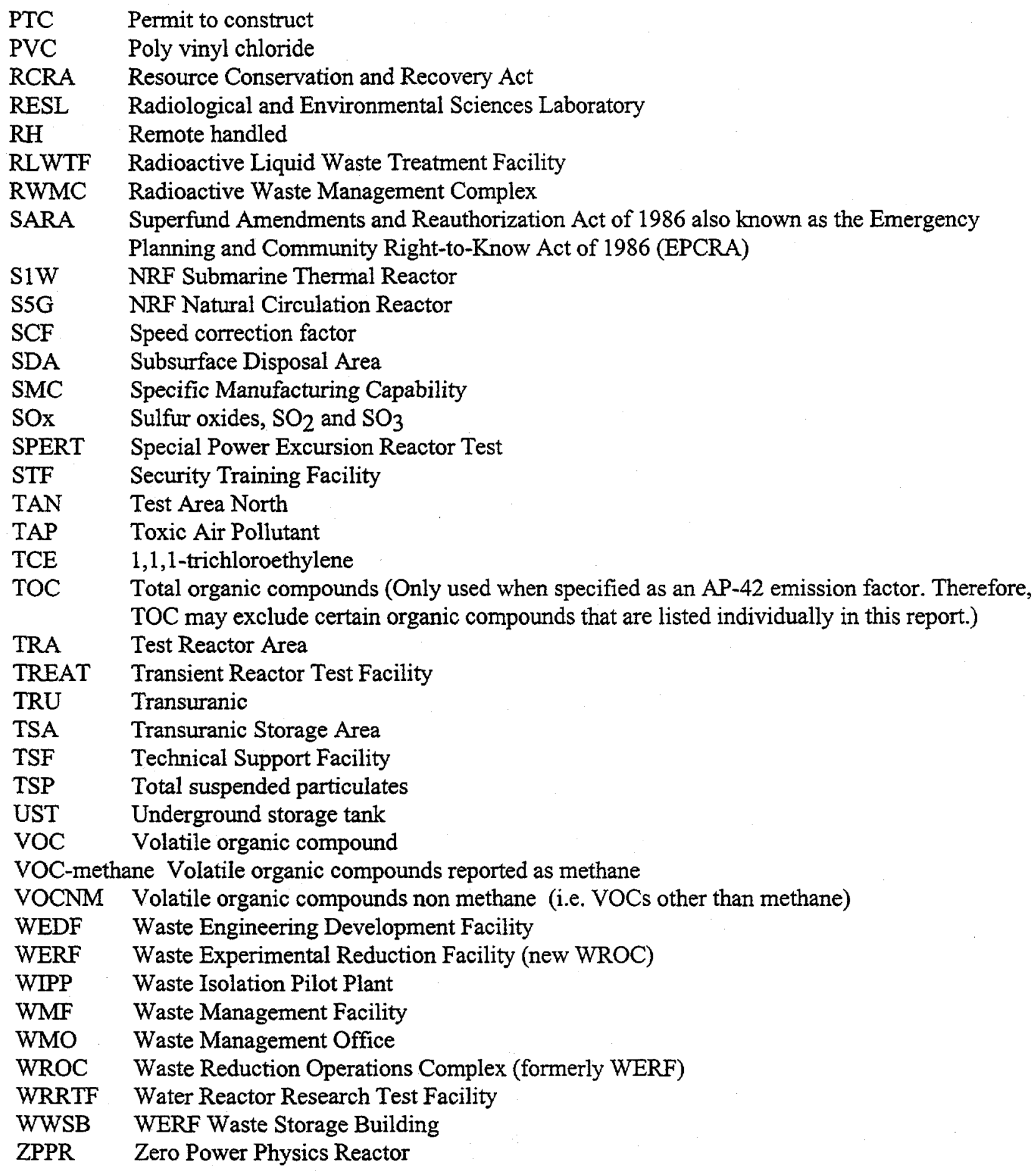




\section{INTRODUCTION}

This report presents 1998 source and emissions data for nonradionuclide pollutants from operations at the Idaho National Engineering and Environmental Laboratory (INEEL). This report describes the emission inventory process used at the INEEL, sources other than insignificant sources, and provides emissions estimates for stationary sources.

The INEEL is an 890 square mile research facility managed by the U.S. Department of Energy (DOE) and contains approximately 600 buildings and 500 other structures. The size and complexity of the INEEL required the development of the Air Emission Inventory System, an ORACLE-based database system, that maintains the emissions inventory. The Air Emission Inventory System utilizes the United States Environmental Protection Agency's (EPA's) Compilation of Air Pollutant Emission Factors (AP42) calculations to estimate emissions for many of the general sources.

Recent changes in state and federal regulations have left PM-10 the only regulated type of general particulate. Where emission factors are available PM-10 factors have generally replaced TSP factors in this report. There are some cases where TSP is still being determined. Rather than report TSP separately from PM-10 the emissions for both of these particulates are being reported as PM-10. This type of summary provides a conservative estimate for PM-10 emissions.

The 1998 Air Emission. Inventory Report includes the following areas at the INEEL (see Figure 2).

1. Argonne National Laboratory-West (ANL-W)

2. Central Facilities Area (CFA)

3. Idaho Nuclear Technology and Engineering Center (INTEC, formerly Idaho Chemical Processing Plant - ICPP)

4. Naval Reactors Facility (NRF)

5. Power Burst Facility (PBF)

6. Radioactive Waste Management Complex (RWMC)

7. Test Area North (TAN)

8. Test Reactor Area (TRA)

9. Miscellaneous Areas

The inventory presently maintains approximately 10,500 vents, and of those vents, approximately 650 are possible emission sources. Emission sources range from conventional fuel combustion and storage sources to nuclear reactor and research facility exhausts. Air contaminants reported in this inventory include nitrogen oxides, sulfur oxides, carbon monoxide, volatile organic compounds (VOCs), hazardous air pollutants (HAPs), and particulates. Emissions of radionuclides are reported in the Idaho National Engineering Laboratory National Emission Standards for Hazardous Air Pollutants (NESHAP) - Annual Report. 
ARA

ANL Auxiliory Reoctor Area

CFA Central Focilities Areo

CTF Contained Test Facility

EBR-1 Experimental Breeder Recctor I

EBR-II Experimental Breeder Reactor II

IET Initial Engine Test

INTEC

MWSF

NOTF

NRF

PBF

RWMC

SMC

STF

TAN

TRA

TREAT

TSF

WEDF

WERF

WRC

WROC

WRRTF

ZPPR

3

Idoho Nucleor Technology and Engineering Center

Mixed Woste Storage Focility

Naval Ordnance Test Focility

Naval Reactors Facility

Power Burst Focility

Rodioactive Waste Management Complex

Specific Manufacturing Copobility

Security Training Focility

Test Area North

Test Reoctor Area

Transient Reactor Test (Facility)

Technicol Support Focility

Waste Engineering Development Facility

Woste Experimental Reduction Focility

Weopons Ronge Complex (Rifle Ronge)

Waste Reduction Operations Complex

Water Reoctor Research Test Focility

J) ( Zero Power Plutonium Reactor 1

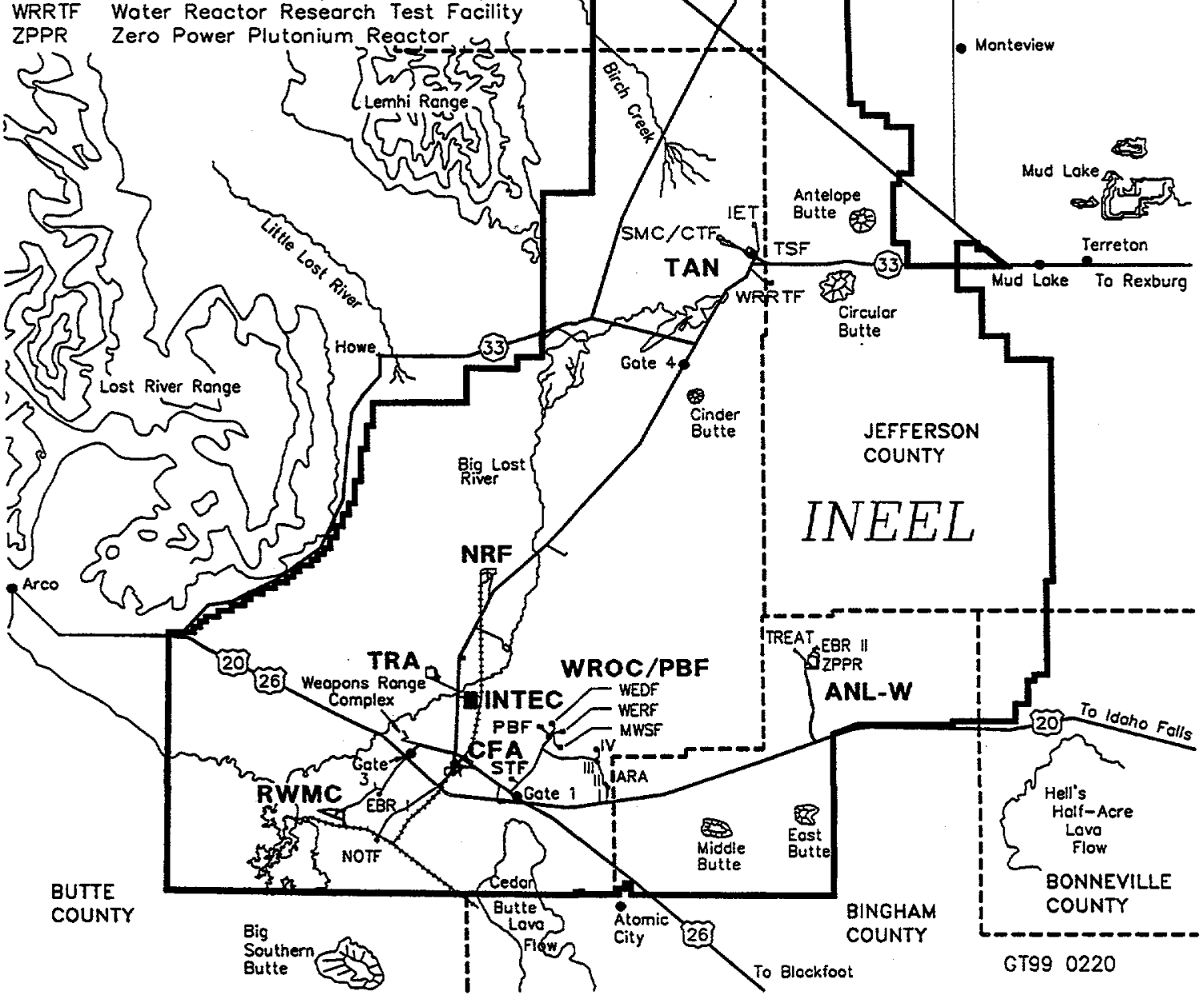

Figure 2. Map of the INEEL site facilities. 


\section{AIR EMISSION INVENTORY PROCESS}

The Air Emission Inventory process was initiated at the INEEL in 1989. In order to evaluate all of the potential sources of air contamination at the INEEL, every vent was inventoried. The process was implemented in three phases (i.e., Phases I, II and III) to ensure comprehensive and accurate data. Data collected from each phase of the inventory process were compiled and managed on an ORACLE-based data management system. Since the initial 1989 inventory process, the Air Emission Inventory System has been redesigned to reflect a production database system.

The INEEL maintains a current inventory of emission sources which reflects any new or upgraded structures, vents, and sources.

\subsection{Air Emission Inventory Phase I}

Phase I of the INEEL Air Emissions Inventory included four activities: identification of potential emission points from existing inventories, surveys of buildings and potential sources, a preliminary classification to eliminate vents that were not potential air pollution sources, and an evaluation of existing air permits and permit applications.

\subsubsection{Acquisition of Existing Data}

Previous air emission inventories were evaluated to determine the usefulness of the compiled data for the initial Air Emission Inventory. Data used from an existing inventory were checked for accuracy by comparing the data collected during the Phase I inventory.

\subsubsection{Vent Inventory}

Standardized forms were developed to collect and organize data.. Building Source Forms were developed to record the survey team members' names, building contact's name, source number, description and location, and any other information available for the source. Any vent considered a potential air pollution source was recorded on a Form 1. Building Summary Forms (Form 2) were developed to list and briefly describe all vents on a building, including those not listed as potential sources of air pollution.

\subsubsection{Vent Classification}

Vents were considered a source if the vent had the potential to emit any criteria pollutants (carbon monoxide, sulfur oxides, nitrogen oxides, particulates, lead, and volatile organic compounds), noncriteria pollutants (asbestos, beryllium, mercury, vinyl chloride, radionuclides, fluorides, sulfuric acid 
mist, hydrogen sulfide, and reduced sulfur compounds), or toxic air pollutants listed in Tables V-A, V-B, and V-C of the draft State of Idaho Guidance Manual for Obtaining a Permit to Construct, Modify or Operate an Air Pollution Source.

Vents that were considered sources included those associated with combustion processes; radiological processes (or vents on radiologically contaminated equipment); chemical process exhausts; storage tank vents; fume hood exhausts; and area sources such as waste piles, evaporation ponds, and lagoons. If a vent was considered a potential source of air pollutants, it became part of the Phase II inventory.

\subsubsection{Existing Permits}

The Phase I inventory gathered all existing Idaho Air Quality Bureau permits and permit applications. Data from the existing permits were incorporated into the Phase II portion of the inventory.

\subsection{Air Emission Inventory Phase II}

Phase II of the inventory included the collection of detailed data for vents identified as potential sources of air contamination in Phase I. Phase II data included operating and engineering parameters necessary for emission calculations, physical location, process descriptions with flow diagrams if necessary and available, and any previously permitted or otherwise documented information concerning potential emissions.

The initial aspects of the Phase II inventory organized the preliminary information for a given area and their corresponding structures. The material included available drawings, data forms, permit applications, and other existing data. Any additional information required to estimate emissions was also collected and included engineering drawings and safety analysis reports, documentation of contacts with equipment manufacturers, and documentation of interviews with shift supervisors, operators, and area landlords.

On completion of data collection, the status of any unknown and out-of-service vents was determined. Unknown vents were changed to either a vent with no emissions, or a potential source of emissions. Many of these inactive vents were permanently out of service while others were only temporarily inactive. A summary of the decision process used to determine the status of unknown vents and whether any estimates needed to be made concerning their emissions or potential emissions is provided in Figure 3.

The data were compiled on a set of inventory forms. The Phase II inventory comprised 16 different data forms, but not all were needed for each source. The Phase II forms were organized into several levels, where each level was divided into increasingly more detailed degrees of data to be collected. Figure 4 is a flow chart diagramming the use of Phase II forms. 
Active source

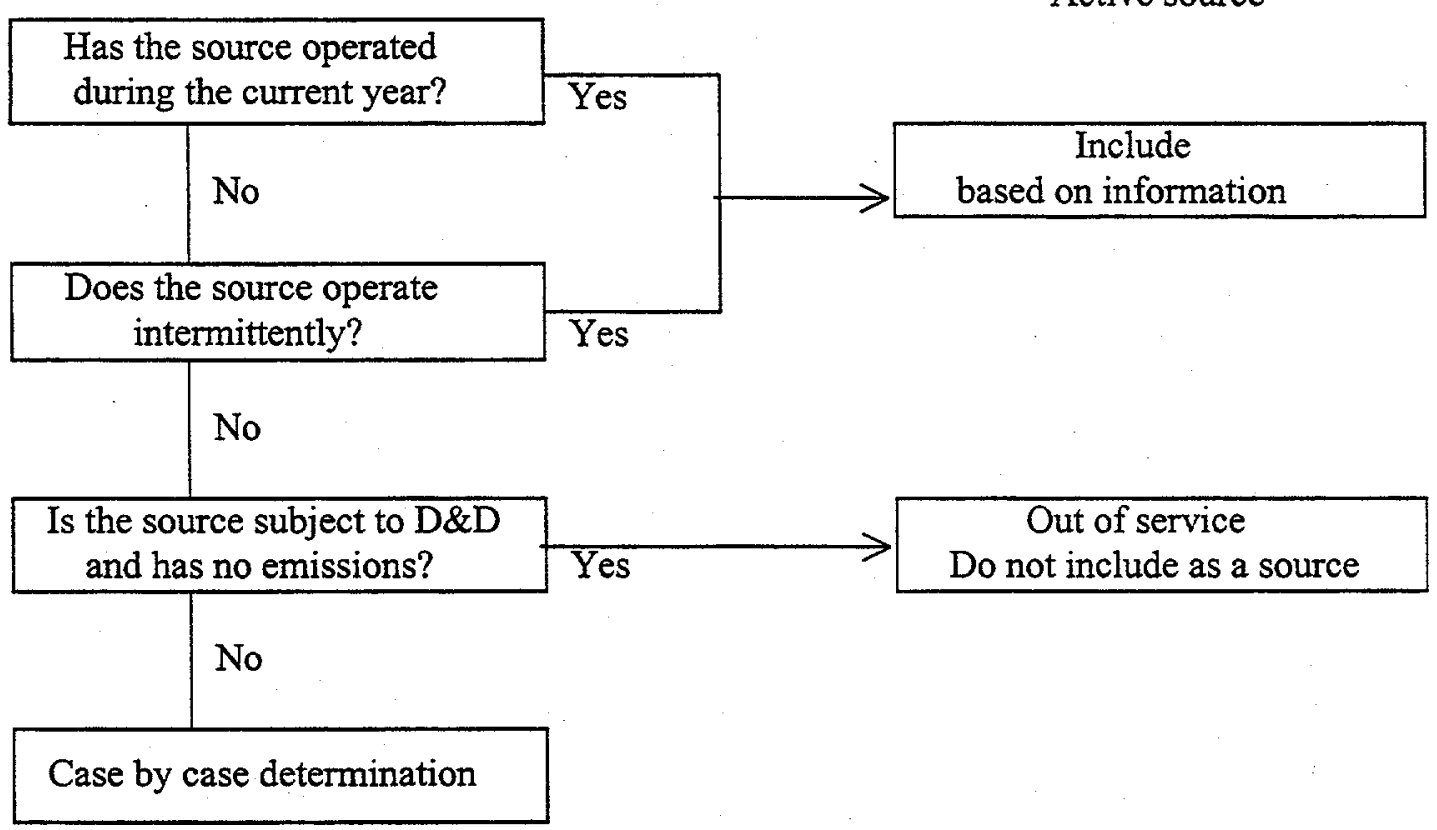

Figure 3. Source classification decision. 


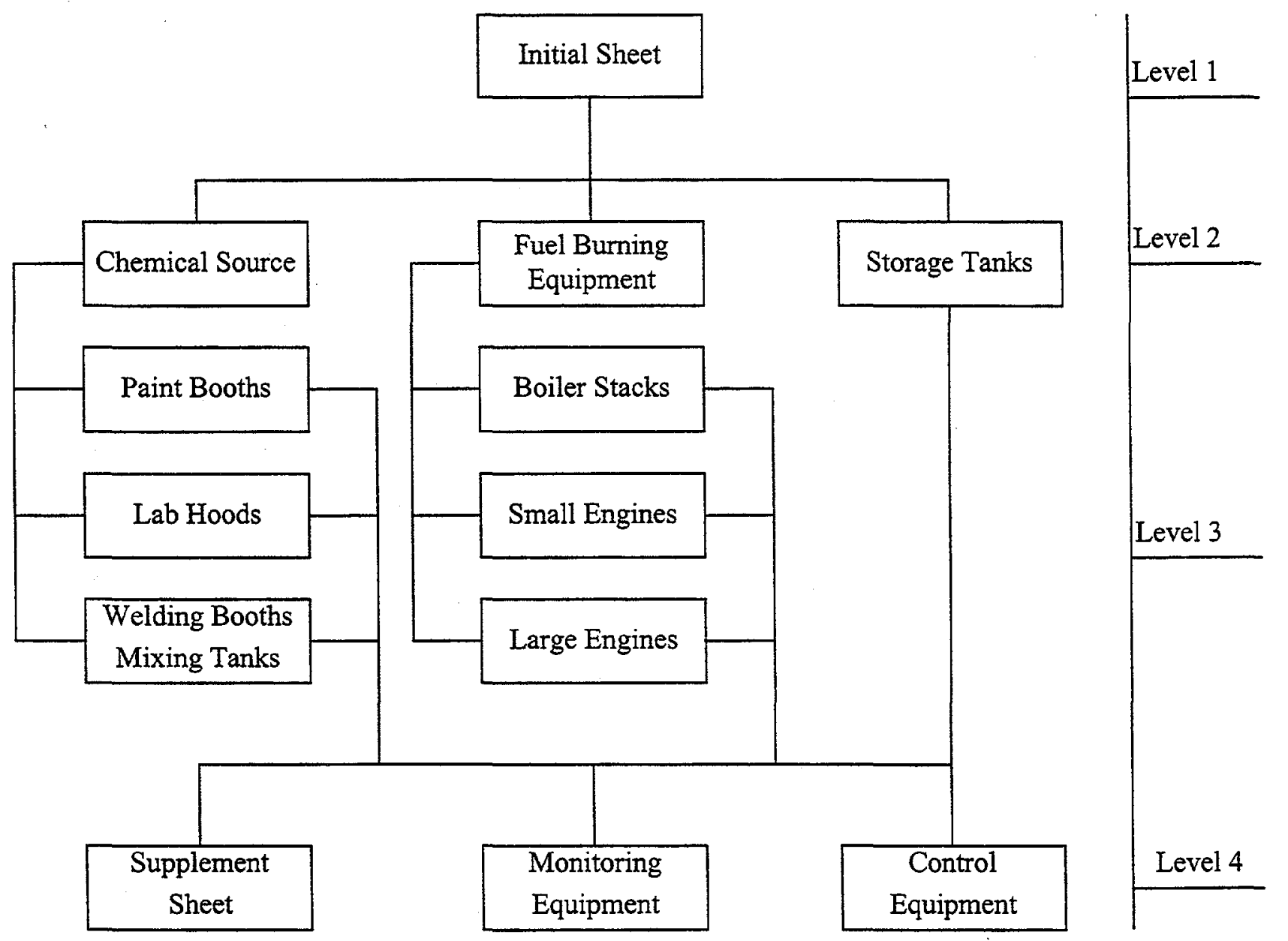

Figure 4. Phase II inventory forms hierarchy. 
Level 1 forms were prepared for every potential source. These forms described the process stack and provided a gross evaluation of the source type. The source type section of the form identifies the appropriate Level 2 form. A Level 2 form is completed depending on the source type. Level 2 forms are supplied for chemical sources, fuel burning equipment, volatile organic liquid storage, and inorganic chemical storage. The Level 2 forms are used to gather source-specific information required for emission estimates. A check box is provided to indicate which Level 3 forms are required.

Level 3 forms compiled information on the chemicals, fuel, and materials used in specific sources. Level 4 is the final tier in the Phase II inventory form classification. This level was used to record information on pollution control equipment, pollution monitoring equipment, and additional information applicable to fume or laboratory hoods and paint booths.

Not all sources could be standardized on these forms and were handled on a case-by-case basis using generic data forms. The generic forms recorded sources whose emissions had to be calculated by hand or were of such an unusual nature that the standardized forms are not applicable.

\subsection{Air Emission Inventory Phase III}

Phase III utilized the data gathered during Phases I and II to estimate the emissions of air pollutants from sources at the INEEL. The development of Phase III included calculating emissions from the following sources:

- Industrial engines

- Laboratories

- Organic storage tanks

- Main stacks
- Boilers

- Painting operations

- Welding operations

- Miscellaneous/generic

The calculations for the above sources involve EPA acceptable methods per Volumes I and II of $\mathrm{AP}-42$ and used several assumptions for each source or used best engineering estimates. Descriptions of the various calculations used to estimate the emissions from the INEEL sources are provided in Section 4 of this report.

\subsection{Air Emission Inventory Annual Update}

The INEEL contractors and their associated facilities are required to provide information into the Air Emission Inventory System to reflect annual operations. The purpose of the annual update is to estimate the emissions for the previous calendar year, reflect current source status, and update information to reflect current operations and area descriptions.

The 1998 AEI continues to follow the AOP description of emission sources. In the past most air pollution sources were individually tracked and their emissions quantified. The AOP categorized sources into significant, not significant, and exempt insignificant. The number of sources that are 
individually reported has been limited to those that have individual emission limits. These emission limits can be from permits, prevention of significant deterioration (PSD) increment consumption, or from justification of not-significance by use of an emission quantity. Those sources that are not individually reported are now included in one of the general site summaries for specified source categories.

Each INEEL contractor provides a coordinator for each operating area. The data to be updated is provided to each responsible area-specific coordinator for data entry. The area-specific coordinators enters the data via computers and the forms are generated by the database. Each form details all the information pertinent to each source.

After the updated information is inputted, the applicable emission calculations are performed. The calculations performed during the update process follow the guidelines and assumptions as presented in the initial Air Emission Inventory report (DOE-ID 1991). Additional assumptions or guidelines are provided where applicable.

The data update process includes deleting sources, adding sources, process changes for sources, recalculating emissions, and adding data to reflect current operations. If a new vent, stack, source, or building has been added since the last survey, Phase I and Phase II forms are used to report the information.

\subsection{Significant Sources}

Significant sources discussed in the AEI are made up of all the state and federal air permitted sources and those sources that do not have permitted requirements and do not qualify as an insignificant or not significant source. Each area description in Section 3 of the AEI provides a list or discussion of its' significant nonradioactive sources. Radioactive sources, which are all significant sources in the AOP, are not listed nor have their radioactive emissions been detailed in this AEI report but are included in the NESHAP annual report for the INEEL. All significant sources are described in the AEI and have their nonradioactive emissions detailed.

\subsection{Not Significant Sources}

Not significant activities are considered not significant based on IDAPA 16.01.01.317.b. These activities will not be required to meet the substantive requirements to the operating permit (IDAPA 16.01.01.314.04.a), and information such as state application forms, descriptions, and compliance plans is not provided. The following is a list of categories of not significant activities applicable to the INEEL.

- Organic storage vessels - Not significant organic storage vessels at the INEEL are used primarily for fuel oil and gasoline storage and occasionally for solvent storage, kerosene, hydrocarbon diluent, or stoddard solvent. Three categories of organic storage tanks are not significant activities at the INEEL:

a tanks smaller than 10,000 gallons (IDAPA 16.01.01.317.b.i (3)

b tanks larger than 10,000 gallons that are underground (IDAPA 16.01.01.317.01.b.i (30) 
c tanks larger than 10,000 gallons that are outside buildings (excluding gasoline) (IDAPA 16.01.01.317.01.b.i (30)

- Inorganic storage tanks - Inorganic storage tanks at the INEEL may be considered not significant based on IDAPA 16.01.01.317.01.b (19), "tanks, vessels, and pumping equipment, with lids, or other appropriate closure for storage or dispensing of aqueous solutions of inorganic salts, bases and acids excluding

$99 \%$ or greater $\mathrm{H}_{2} \mathrm{SO}_{4}$ or $\mathrm{H}_{3} \mathrm{PO}_{4}$

$70 \%$ or greater $\mathrm{HNO}_{3}$

$30 \%$ or greater $\mathrm{HCl}$

More than one liquid phase where the top phase is more than one percent VOCs"

- Stationary fuel burning engines - Equipment at the INEEL that provides emergency or standby power, compressed air, or fire water pumping

- Heaters, boilers - Space heating and hot water heaters using natural gas, propane or kerosene and generating less than five million Btu per hour are not significant based on IDAPA 16.01.01.317.01.b.i (18)

- Furnaces, boilers Any fuel burning equipment for indirect heating or for heating and reheating furnaces using natural gas, propane gas, or liquefied petroleum gas with a capacity less than 50 million Btu per hour input is not significant based on IDAPA 16.01.01.317.01.a.i (1)

- Multi-craft shops - The following activities are classified as not significant. Painting shops using less than two gallons per day. Larger paint shops with less than one ton per year of VOC-nonmethane emissions. Welding shops not using not more than one ton per day of welding rods. Fabrication shops at the INEEL are considered not significant based on IDAPA 317.01.a.i (54) with some restrictions. Other multi-craft shops at the INEEL may include parts cleaning and are considered not significant based on IDAPA 317.01.b.i (30).

- Laboratories - Nonradioactive emissions from analytical and research laboratories at the ENEEL are considered not significant based on IDAPA 16.01.01.317.01.a.i (1) and 16.01.01.220.a. These not significant activities include laboratory equipment used exclusively for chemical and physical analysis, research or education, including ventilating and exhaust systems for laboratory hoods. IDAPA 16.01.01.317.01.b.i (30) considers laboratories not significant if the VOC-nonmethane emissions are below two tons and below one ton limit for any HAP.

Most of these general source categories have subcategories that have varied types of qualifying requirements. Fugitive dust sources such as landfills and borrow or gravel pits associated with an area are listed with their emissions estimates in the AOP but are not quantified annually in the AEI.

The AEI lists all not significant sources individually in their respective area descriptions in Section 3. Those sources that use the justification of not emitting more than a given quantity of pollutant to be classified as a not significant source and those sources that consume part of an allowable increment under the PSD regulations have their individual emissions detailed in this report. Justifications for each source and identification of those sources that consume increment under the PSD regulations are provided in the area volumes of the AOP. Those sources that do not have an individual need to detail their emissions have their emissions grouped together according to the category in which they are grouped. This grouping of emissions provides the INEEL with an envelope for these emission 
calculations without the need to track each source on an individual basis. The descriptions for these emission methodologies are provided in Section 4 of this report.

\subsection{Exempt Insignificant Sources}

Exempt insignificant activities are categorically exempt from all operating permit requirements as allowed by IDAPA 16.01.01.317.01.a. The INEEL uses the categorically exempt insignificant activity list which is tailored to the types of activities that occur at the INEEL. This list does not include any sources that would be subject to an applicable requirement. INEEL activities that fall into one of the categories listed below will not be specifically addressed and emissions associated with these activities will not be tracked so subsequently reported. INEEL categorically exempt insignificant activities include the following activities.

The categories of exempt insignificant sources are as follows:

- Landscaping and ground keeping activities - INEEL landscaping activities include lawn care, plant care, small engine landscaping equipment, weed control, pest control, and general cleanup activities.

- Janitorial activities - INEEL janitorial activities include general cleaning of INEEL structures and areas, general housekeeping, steam sterilizers, and wax application. Application of chemicals for cleaning purposes is included.

- Cafeteria activities - INEEL cafeteria activities are preparation of meals by baking, frying, grilling, or any other means; cleanup of preparation areas; and cleaning of cafeteria utensils and equipment.

- Personal care activities - INEEL personal care activities include lavatory activities, sewage lagoons and pumping stations, sewage treatment and disposal, laundering, and use of personal care items.

- Office activities - INEEL office activities include general office support, printing operations, copy machines, blueprint machines, photographic laboratories, and office solid waste collection.

- Safety activities - INEEL safety activities include safety, emergency response, and fire protection training fires, outdoors firearms practice ranges, relief valves, rupture discs, traffic flares, security training, and salting or sanding of winter road surfaces.

- Maintenance activities - On location, INEEL maintenance activities include general structure maintenance (painting, welding, carpentry), roofing and roofing repair, machining, nonasbestos insulation, equipment cleaning and preservation, fuel burning equipment maintenance and overhaul activities, road maintenance and repair, parking lot maintenance and repair, and vehicle testing, maintenance, and repair.

- Material storage - INEEL material storage includes any clothes containers, storage of laboratory chemicals, solid materials (dust-free handling), solid waste containers, paint storage and battery room exhausts. Material storage also includes storage tanks limited to storage of ' surfactants, lubricants, hydraulic fluid, butane, propane, liquefied petroleum gas, and cooking oils, and RCRA temporary accumulation areas.

- Plant support - INEEL plant support activities include drum handling and sampling, air compressors less than 100 horsepower, sand blasters, oil/water separators, nonprocess drying 
ovens, water treatment (slat bins, chlorination units, demineralizers, ion exchange, and regeneration of demineralizers and ion exchange), material testing, transformers, satellite accumulation areas, and reservoirs and pumping equipment limited to surfactants, lubricants, hydraulic fluid, cooking oils, hot cell window oil, and venting of buildings which house significant an nonsignificant sources/activities that have their own separate vents.

- Medical care activities - INEEL medical activities include storage of medical supplies, use of chemicals to support medical activities, $\mathrm{x}$-ray services, administering medications, and emergency medical operations.

- Portable small (less than $100 \mathrm{hp}$ ) fuel burning equipment - INEEL small portable fuel burning equipment includes equipment available to borrow from the central equipment pool.

The AEI does not list or quantify emissions from sources associated with these categories. However, due to the large number of small portable fuel burning equipment on the INEEL, emissions from these sources have been estimated for the first time in this years report. Section 4 describes the process for determining small engine emissions.

\subsection{AEl Numerical Database}

The AEI data base tracks numbers down to 0.00001 (1.0E-5). There is a lower limit where the data base rounds to zero. Numbers less than $4.9 \mathrm{E}-6$ are rounded to zero by the system. Numbers from 5.0E-6 to $9.9 \mathrm{E}-6$ are rounded up to $1.0 \mathrm{E}-5$. From $1.0 \mathrm{E}-5$ upward the exact number is retained by the system.

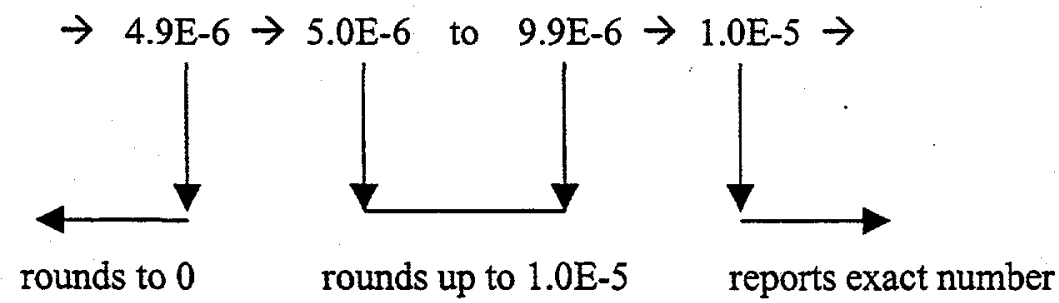

There are occasions where the hourly rate or annual emission of a chemical is less than $5.0 \mathrm{E}-6$. This would cause the system to report zero for the applicable emission. The consequence is that it is possible to have a zero hourly emission rate and yet have an annual total. It may also result in having an hourly emission rate and yet have zero annual emissions. The AEI database will correct this in the future to show all numerical values in scientific notation. 


\section{1998 UPDATE}

\subsection{INEEL Site-wide Changes}

The 1998 AEI for the INEEL reflects changes from the 1997 AEI in reporting and source information updated during preparation of the AOP. These changes occur at sources located in all of the eight functional areas, and are categorically applied to sources where appropriate. Therefore, these categorical changes are summarized herein to eliminate redundancy in the area-specific updates (sections 3.2 through 3.10).

Categorical changes include the following:

Not significant sources of emissions, as described in the INEEL Title V Operating Permit Application and new sources that have been added to the list, will be listed in this inventory. Only those not significant sources that use an emission quantity to justify being not significant will be individually described.

Fuel burning equipment that are PSD consumers have been reported individually in the past. This year all not significant fuel burning sources are being addressed in a grouped area source. The data used in determining emissions is provided in Section 4.1.4 of this report.

Not significant sources that are not individually described, will be included in areas grouped summary for that category of emission sources. There are three area group sources discussed in this report. They are:

Area-GRP-1: All non-boiler fuel burning equipment diesel gasoline

fuel oil

propane

liquid natural gas

Area-GRP-2: Organic storage tanks

Area-GRP-3: Laboratories, fumehoods, paint shops, welding, craft and wood working shops

Emissions from small portable fuel burning equipment are included in this report. These emissions are grouped and the method of estimating their emissions are described in section 4 of this report. Grouping these emissions was necessary because the AEI database currently zeros any emissions less than 1.0E-05. This 1.0E-05 limit in the AEI database will be corrected for next year to report any quantity using scientific notation.

Hazardous air pollutants are identified and emissions are reported as a group for all sources at the INEEL. Emissions from these sources had to be grouped because emissions from each individual source was often small enough that the AEI database would zero the emission. The database will be modified to report all emissions in scientific notation and no zeroing will occur for next years report. 


\subsection{Argonne National Laboratory-West}

\subsubsection{Area Description}

ANL-W is a laboratory facility associated with the INEEL and operated by the University of Chicago for the DOE Chicago Field Office. ANL-W is located near the southeast corner of the INEEL, approximately three miles north of U.S. Highway 20 . ANL-W is presently involved in research and development, waste treatment processes and reactor shutdown activities.

Several facilities shown on the area plot plan of ANL-W (Figure 5) are not included in the Air Emissions Inventory Report because their air emission sources are radiological sources. Radiological sources are covered, and their emissions reported in, the annual INEEL NESHAP report.

\subsubsection{Significant Source Descriptions}

ANL-W has 13 non-radiological sources which are included in the Air Emissions Inventory Report. Of these 13 sources, five are regulated emergency or standby equipment, two are fuel oil storage tanks with holding capacities of greater than 10,000 gallons, four are boilers used to provide saturated steam for site heating and process requirements, one is a permitted facility with VOC emissions of less than 0.1 ton per year, and the last is a permitted paint booth with emission limits of 0.8 ton per year VOC and 0.2 ton per year of TSP and PM-10.

3.2.2.1 Emergency/Standby Equipment. ANL-W , 707-002, 709-008, 709-016, 752A-001, and 768-028 are vent numbers for emergency/standby diesels which are regulated by permit or by a "below regulatory concern" (BRC) letter issued by DEQ. Sources associated with vents ANL-W 707-002, 752A-001, and 768-028 are classified as significant sources because their operations are governed by a BRC letter issued by DEQ. The diesels associated with vents ANL-W 709-008 and 709-016 are classified as significant sources because they are regulated by a PTC/PSD.

3.2.2.2 Diesel Fuel Storage Tanks. ANL-W 755A-001 and 755B-002 are vent numbers assigned to two fixed roof diesel fuel storage tanks holding 100,000-gallons and 60,000-gallons respectively. Fuel in these tanks is used to supply the boilers discussed in 3.2.2.3.

3.2.2.3 Boilers. ANL-W 768-022, $-024,-027$, and -034 are vent numbers assigned to four water tube boilers located in the EBR-II power plant. The boilers provide saturated steam for site heating and process requirements. The site steam system operates at a pressure of between 75 and $200 \mathrm{psig}$ depending on seasonal and system needs. Generally, only one or two boilers are needed to meet system demand; however, during severe weather, a third boiler is needed. A fourth boiler provides flexibility to schedule maintenance and allow system reliability in case of an unexpected problem with one of the other three boilers. 


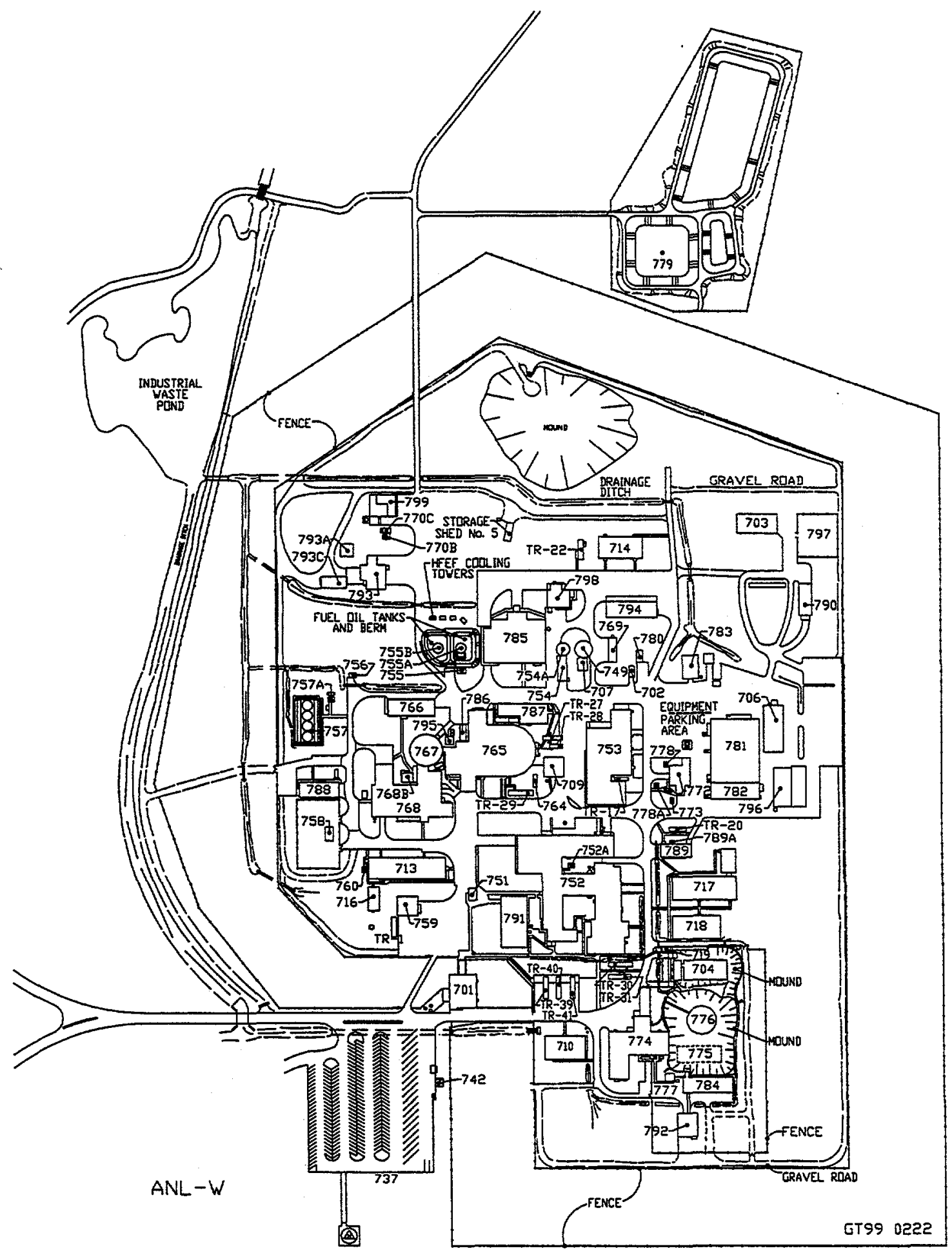

Figure 5. Area plot plan of Argonne National Laboratory-West. 
3.2.2.4 Fuel Conditioning Facility. Prior to the shutdown of the EBR II reactor, the Fuel Conditioning Facility (FCF) was modified and equipped to demonstrate fuel cycle technology. The facility is now being used to apply this technology to high-level nuclear waste remediation research. As part of this operation VOC containing decontamination solvents may be used to decontaminate equipment. VOC emissions from this operation are limited by the PTC/PSD issued for the FCF. FCF emissions are vented via a 200 foot stack (ANL-764).

3.2.2.5 Paint Booth. ANL-W 753-029 is the vent number assigned to a permitted maintenance/utility paint spray booth. Emissions from this source are limited to 0.8 tons/year VOC and 0.2 tons/year TSP and PM- 10 by a PTC.

\subsubsection{Not Significant Sources}

Not significant sources include sources with relatively insignificant emissions and sources with emissions that may be comparable to significant sources but which are not classified as significant (such as emergency diesel equipment which is old enough not to have required a permit). Not significant sources at ANL-W include laboratory fumehoods, paint spray booths which apply less than 2 gallons of paint per day, welding booths which use less than 1 ton of welding rod per day, multi-craft areas which are used for repairs and facility maintenance, emergency/standby diesel equipment, a potable water chlorinating unit, and organic storage tanks with holding capacities of less than or equal to 10,000 gallons.

Table 2. Not significant sources at ANL-W.

\begin{tabular}{llll}
\hline $\begin{array}{c}\text { Bldg } \\
\text { number }\end{array}$ & Building name & $\begin{array}{l}\text { Vent } \\
\text { number }\end{array}$ & \multicolumn{1}{c}{ Description } \\
\hline 701 & Security Bldg & 009 & $143 \mathrm{hp}$ diesel generator \\
& & 012 & $500 \mathrm{gal}$ diesel AST \\
& & 020 & $25 \mathrm{gal}$ diesel storage tank \\
704 & Fuel Manufacturing Facility & 007 & 90 gal diesel storage tank \\
& & 015 & $86 \mathrm{hp}$ emergency diesel generator \\
707 & Fire Pump House & 001 & 280 gal diesel storage tank \\
709 & FCF Safety Equipment Bldg. & 001 & 1,100 gal diesel storage tank \\
& & 009 & 1,100 gal diesel storage tank \\
720 & TREAT Reactor Bldg. & 008 & Multi-craft shop \\
& & 009 & Multi-craft shop \\
& & 017 & $173 \mathrm{hp} \mathrm{diesel} \mathrm{generator}$ \\
& & 018 & $46 \mathrm{hp} \mathrm{diesel} \mathrm{generator}$
\end{tabular}


Table 2. Not significant sources at ANL-W.

\begin{tabular}{|c|c|c|c|}
\hline $\begin{array}{c}\text { Bldg } \\
\text { number }\end{array}$ & Building name & $\begin{array}{l}\text { Vent } \\
\text { number }\end{array}$ & Description \\
\hline & & 021 & 15 gal diesel day tank \\
\hline & & 022 & 10 gal diesel day tank \\
\hline & & 025 & 500 gal diesel AST \\
\hline 721 & TREAT Office Building & 003 & 500 gal diesel storage tank \\
\hline \multirow[t]{2}{*}{725} & Fire Station & 001 & $80 \mathrm{hp}$ diesel generator \\
\hline & & 002 & 500 gal diesel AST \\
\hline \multirow[t]{4}{*}{742} & Gasoline/Diesel Dispensary & 002 & 4,000 gal diesel storage tank \\
\hline & & 005 & 2,300 gal diesel storage tank \\
\hline & & 006 & 2,300 gal gasoline storage tank \\
\hline & & 007 & 3,000 gal diesel storage tank \\
\hline \multirow[t]{2}{*}{752} & Lab/Office Bldg & 004 & Analytical laboratory \\
\hline & & 005 & Analytical laboratory \\
\hline \multirow[t]{2}{*}{$752 \mathrm{~A}$} & Diesel Generator Bldg. & 002 & 50 gal. diesel day tank \\
\hline & & 005 & 500 gal diesel AST \\
\hline 753 & Plant Services Bldg. & 012 & Multicraft shop \\
\hline \multirow[t]{2}{*}{754} & Well Pump House \#1 & 001 & 150 gal diesel storage tank \\
\hline & & 003 & $77 \mathrm{hp}$ diesel generator \\
\hline 754 & Well Pump House \#1 & Fugitive & Potable water chlorinating unit \\
\hline \multirow[t]{4}{*}{768} & Power Plant & 003 & $741 \mathrm{hp}$ diesel generator \\
\hline & & 004 & 500 gal diesel storage tank \\
\hline & & 005 & $10,000 \mathrm{gal}$ diesel storage tank \\
\hline & & 007 & 60 gal diesel day tank \\
\hline $768 \mathrm{~B}$ & Water Chemistry Lab & 001 & Analytical laboratory \\
\hline \multirow[t]{2}{*}{772} & EBR-II Engineering Lab & 001 & Machining, weld area \\
\hline & & 022 & Analytical laboratory \\
\hline \multirow[t]{2}{*}{774} & ZPPR Support Wing & 001 & $166 \mathrm{hp}$ diesel generator \\
\hline & & 002 & 25 gal diesel day tank \\
\hline \multirow[t]{2}{*}{782} & Machine Shop & 001 & Welding area \\
\hline & & 028 & Welding area \\
\hline
\end{tabular}


Table 2. Not significant sources at ANL-W.

\begin{tabular}{llll}
\hline $\begin{array}{c}\text { Bldg } \\
\text { number }\end{array}$ & Building name & $\begin{array}{l}\text { Vent } \\
\text { number }\end{array}$ & \multicolumn{1}{c}{ Description } \\
\hline 785 & HFEF & 009 & Mineral spirit overflow tank \\
& & 015 & 500 gal diesel storage \\
& & 017 & 525 hp emergency diesel generator \\
788 & EBR-II Maintenance Shop & 013 & Spot weld hood \\
& & 014 & Spot paint \\
789 & EBR-II Engineering Lab & 001 & Multi-craft area \& analytical lab \\
798 & RLWTF & 007 & 30 gal diesel day tank \\
& & 008 & 27 hp emergency diesel generator \\
799 & SPF & 016 & 150 gal diesel storage tank \\
& & 017 & $192 \mathrm{hp} \mathrm{diesel} \mathrm{generator}$ \\
\hline
\end{tabular}

\subsubsection{Summary of ANL-W Emissions}

Totals of pollutant emissions from significant sources at ANL-W during 1998 are summarized in Table 3.

Table 3. Summary of nonradionuclide principal pollutants at ANL-W.

\begin{tabular}{|c|c|c|}
\hline \multirow[b]{2}{*}{ Pollutant } & \multicolumn{2}{|c|}{ Emissions } \\
\hline & $\begin{array}{c}\text { Hourly } \\
\text { lb/hr }\end{array}$ & $\begin{array}{c}\text { Annual } \\
\text { ton } / \mathrm{yr}\end{array}$ \\
\hline Carbon monoxide & $1.0 \mathrm{E}+01$ & $1.8 \mathrm{E}+00$ \\
\hline Nitrogen oxides & $4.4 \mathrm{E}+01$ & $7.3 E+00$ \\
\hline$P M-10$ & $2.5 \mathrm{E}+00$ & $3.7 \mathrm{E}-01$ \\
\hline Sulfur oxides & $8.1 E+01$ & $5.0 \mathrm{E}+01$ \\
\hline VOC - nonmethane & $2.5 \mathrm{E}+01$ & $2.0 E+00$ \\
\hline
\end{tabular}




\subsubsection{Summary of ANL-W Changes}

Differences between information presented in the 1997 and 1998 AEI are summarized in Table 4.

Table 4. Summary of changes from 1997 to 1998 Air Emission Inventory Report.

\begin{tabular}{lll}
\hline Emission point & Changes to the 1998 Inventory & Description \\
\hline $701-012$ & 500 gal diesel AST replaces 300 gal UST & Tank replacement \\
$720-025$ & 500 gal AST replaces 1000 gal UST & Tank replacement \\
$752 \mathrm{~A}-005$ & 500 gal AST replaces 500 gal UST & Tank replacement \\
& & \\
Sources Added to AEI & \\
$725-001$ & Added & $80 \mathrm{hp}$ diesel generator \\
$725-002$ & Added & 500 gal diesel AST \\
\end{tabular}




\subsection{Central Facilities Area}

\subsubsection{Area Description}

CFA is located in the southern part of the INEEL, roughly 2.5 miles north of U.S. Highways 20 and 26. The original facilities at CFA were constructed during 1940 through 1950 and were used to house Naval Gunnery Range personnel and later National Reactor Testing Station personnel. The facilities have since been modified to fit the changing needs of the INEEL and now provide four primary types of functional space: craft, office, service, and laboratory.

The craft areas consist primarily of four multicraft shops, as well as warehouses for craft materials storage. Craft activities include painting, welding, carpentry, machining, and other related crafts needed to support INEEL operations.

Office space is provided for administrative, scientific, and engineering personnel, particularly those associated with labs and service groups. Services at CFA are provided for the support of the INEEL and include bus and vehicle maintenance, equipment mechanics, equipment operation, radio and alarm shops, telecommunication facilities, cafeterias, service stations, fuel distribution, facility maintenance, instrument calibration, and training. Laundry and respirator decontamination activities were discontinued in June 1993.

The CFA Landfill Complex is estimated to be a fugitive source of particulate. The CFA landfill services all of the INEEL, disposing only industrial and commercial wastes and asbestos in proper containers. During 1993, the INEEL Landfill Complex relocated disposal activities within the complex from the CFA Landfill III Extension to the area associated with the bulky waste pit. Dirt moving activities, soil piles, and vehicle travel at the landfill are estimated to contribute particulate to the atmosphere. Petroleum contaminated media (PCM) soil landfarming is also a source of fugitive emissions at the Landfill Complex.

The EPA computer model, LandGEM, was used to calculate emissions from CFA landfill in 1998. The estimated emissions were based on arid AP-42 factors with codisposal, hazardous and nonhazardous waste. The modeling showed that emissions at the CFA landfill are small and are expected to decrease yearly. For the first time emissions of individual HAPs and VOCs were reported down to 0.00013 pounds (which was mercury). The nonmethane organic carbon release was 534 pounds for 1998. This NMOC includes all the HAPs and VOCs.

Laboratory activities include sample preparation or analysis, health physics support, materials testing, and instrument calibrations. Chemistry and engineering laboratories are used for both research and analysis.

Figure 6 presents an area plot plan of the INEEL and shows the location of the facilities. Figure 7 presents an area plot plan of CFA. 


\subsubsection{Significant Sources}

The more significant emission sources at CFA are the large boilers used to produce steam for most of the buildings, and the dust collection system at the craft shop. All boilers at CFA burn No. 2 fuel oil, and most have a propane ignition. Most boilers provide space heating only and typically do not operate during the summer months ${ }^{a}$.

CFA-690 (RESL) facility is considered to be a significant source for radionuclides as well as the CFA-625 fumehoods. Radiological emissions are shown in the annual NESHAP report rather than the air emissions inventory.

The RESL facility (CFA-690) contains several analytical laboratories and a few environmental laboratories. The laboratories perform the radioisotope analysis of soil and organic samples. These labs generally have two or three hoods per room that vent to large stainless steel stacks. The primary emissions from RESL are acids that are used to digest the samples and then are boiled away as part of the analytical procedure.

a Note: CFA - 617 process steam currently inactive - propane boiler for laundry facility. Note: All boilers must undergo off-season preventative maintenance and associated operational periods of time. 


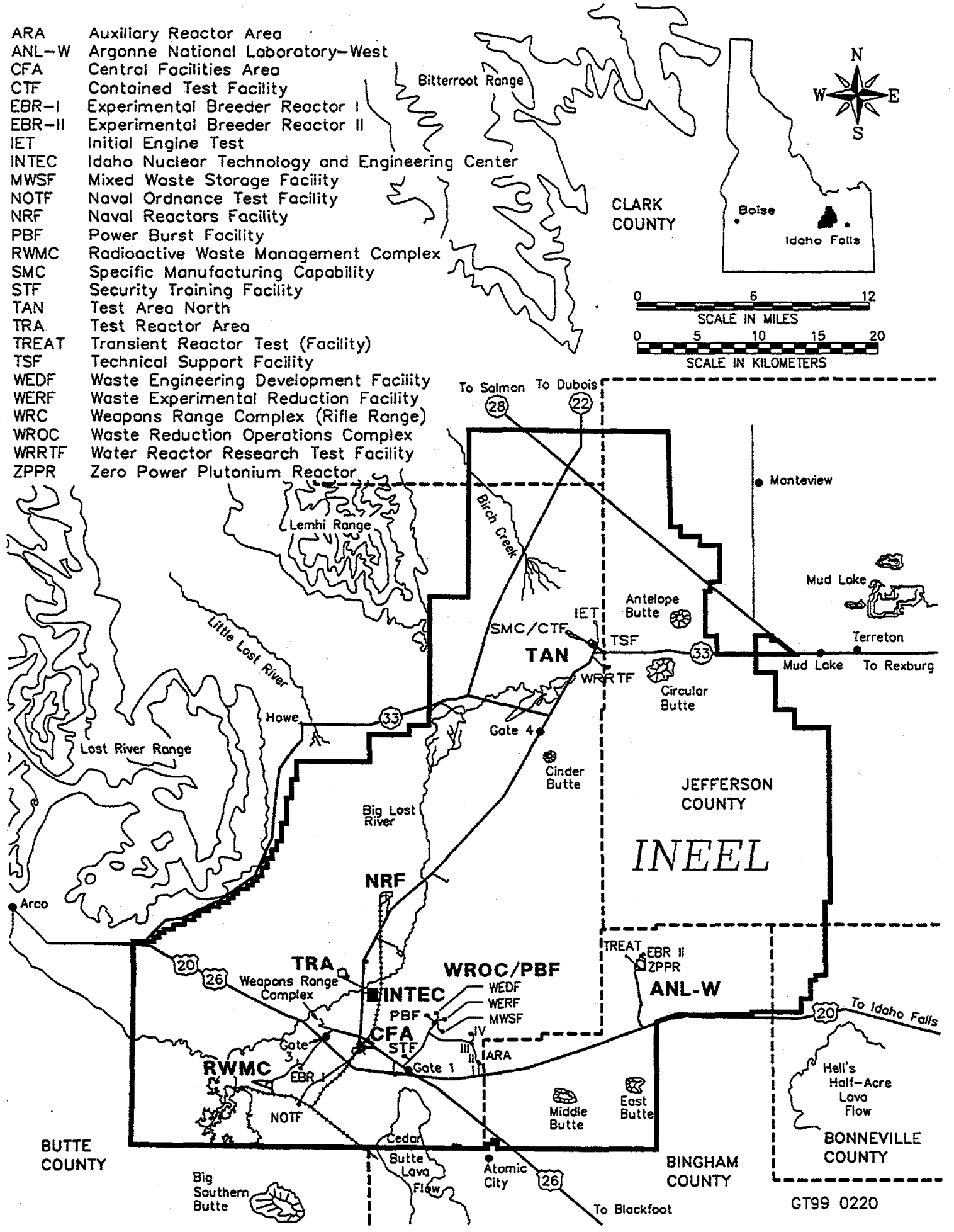

Figure 6. Area plot plan of Block areas. 


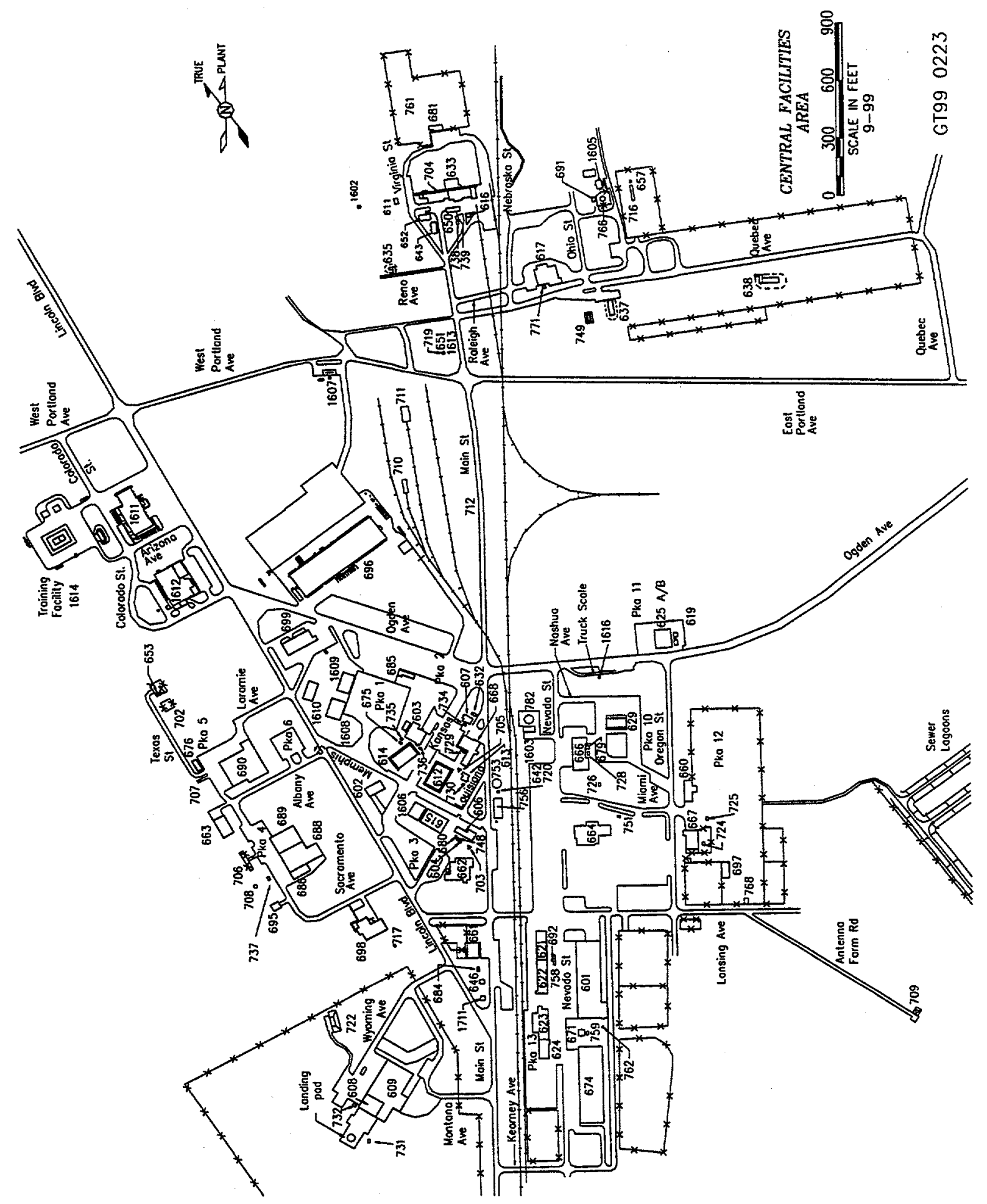

Figure 7. Area plot plan of the Central Facilities Area. 
Table 5. Significant nonradiological air emission sources at CFA.

\begin{tabular}{|c|c|c|c|c|}
\hline $\begin{array}{l}\text { Building } \\
\text { number }\end{array}$ & Building Name & $\begin{array}{l}\text { Vent/stack } \\
\text { number }\end{array}$ & $\begin{array}{l}\text { Source } \\
\text { description }\end{array}$ & Comment \\
\hline CFA-608 & Helicopter building & 001 & Boiler & $\begin{array}{l}\text { Boiler servicing helicopter } \\
\text { facility }\end{array}$ \\
\hline CFA-609 & $\begin{array}{l}\text { Safeguards and } \\
\text { Security }\end{array}$ & 005 & Boiler & $\begin{array}{l}\text { Boiler servicing Safeguards and } \\
\text { Security facility }\end{array}$ \\
\hline CFA-617 & Laundry & 024 & Boiler & $\begin{array}{l}\text { Boiler servicing laundry facility; } \\
\text { currently inactive }\end{array}$ \\
\hline CFA-623 & Craft Shop No. 3 & 007 & Wood Shop & CFA wood shop \\
\hline CFA- 650 & $\begin{array}{l}\text { Boiler house heating } \\
\text { plant }\end{array}$ & 007 & Boiler & $\begin{array}{l}\text { Boiler servicing HPIL CFA-633 } \\
\text { building }\end{array}$ \\
\hline CFA-662 & Cafeteria & 011 & Boiler & Boiler servicing cafeteria \\
\hline CFA-662 & Cafeteria & 027 & Boiler & Boiler servicing cafeteria \\
\hline CFA-668 & $\begin{array}{l}\text { Communications } \\
\text { Building }\end{array}$ & 023 & Boiler & $\begin{array}{l}\text { Boiler servicing } \\
\text { communications building }\end{array}$ \\
\hline CFA-671 & $\begin{array}{l}\text { Boiler house heating } \\
\text { Plant }\end{array}$ & 007 & Boiler & $\begin{array}{l}\text { Boiler servicing } \mathrm{CFA} \\
\text { miscellaneous buildings }\end{array}$ \\
\hline CFA-671 & $\begin{array}{l}\text { Boiler house heating } \\
\text { Plant }\end{array}$ & 008 & Boiler & $\begin{array}{l}\text { Boiler servicing CFA } \\
\text { miscellaneous buildings }\end{array}$ \\
\hline CFA-688 & $\begin{array}{l}\text { Engineering Technical } \\
\text { Center }\end{array}$ & 043 & Boiler & $\begin{array}{l}\text { Boiler servicing the Engineering } \\
\text { Technical Center }\end{array}$ \\
\hline CFA-688 & $\begin{array}{l}\text { Engineering Technical } \\
\text { Center }\end{array}$ & 044 & Boiler & $\begin{array}{l}\text { Boiler servicing the Engineering } \\
\text { Technical Center }\end{array}$ \\
\hline
\end{tabular}

a Radiological source emissions are reported in the annual NESHAP Report.

\subsubsection{Not Significant Sources}

Not significant sources may be point sources that are justified "not significant" by quantification or category. If the source is not significant by quantification, actual emission values are listed in the AEI.

1. Insignificant By Category: No AEI listing 
2. Not Significant: AEI listing of vent/stack number only unless justified by quantification whereby actual and/or emissions are reported

The not significant laboratory sources at CFA constitute the bulk of all sources at the facility which include:

- Fumehoods

- Paint booths

- Welding booths

- Emergency engines

- Heaters/furnaces

- Organic storage tanks

The Transportation Complex was relocated during late 1995 and emission points include organic storage tanks, vehicle emission trunks, propane heaters, and painting and welding booths. This is a relocated source of emissions from CFA-664 and CFA-665. Workscope related to vehicle maintenance has not increased.

The Environmental Chemistry Labs at CFA-625 are divided into two areas, each with a different function. One area is responsible for all radiologically contaminated samples, and the hoods on that half of the building vent to a single stack with a HEPA filter and is considered a significant source. The other half of the laboratory is used to perform analysis of nonradiological samples and vents to an uncontrolled stack and is considered "not significant". Non-radiological emissions from CFA-633 and CFA-690 are also considered "not significant" sources.

Table 6. Not significant sources at CFA.

\begin{tabular}{llll}
\hline $\begin{array}{l}\text { Building } \\
\text { number }\end{array}$ & Building Name & $\begin{array}{l}\text { Vent } \\
\text { number }\end{array}$ & $\begin{array}{l}\text { Source } \\
\text { description }\end{array}$ \\
\hline B08-601 & TAN guard house & 003 & 60 hp standby generator \\
B08-601 & TAN guard house & 001 & 60 gal diesel tank \\
B16-601 & Fire Station No. 2 & 008 & 1,000 gal diesel tank UST \\
B16-704 & NRF parking lot & 001 & 15,000 gal gasoline UST \\
B16-704 & NRF parking lot & 002 & 15,000 gal diesel UST \\
B21-608 & Firing range & 008 & $3-15$ gal weapon cleaning solvent tanks \\
B21-608 & Indoor range & 012 & Air filtration system \\
B23-602 & Tank & 002 & 60 gal indoor diesel tank \\
B27-601 & Main gate guard house & 001 & 60 hp standby generator \\
\hline
\end{tabular}


Table 6. Not significant sources at CFA.

\begin{tabular}{|c|c|c|c|}
\hline $\begin{array}{l}\text { Building } \\
\text { number }\end{array}$ & Building Name & $\begin{array}{l}\text { Vent } \\
\text { number }\end{array}$ & $\begin{array}{l}\text { Source } \\
\text { description }\end{array}$ \\
\hline $\mathrm{B} 27-601$ & Main gate guard house & 003 & 60 gal diesel tank \\
\hline CFA-100 & Area & 001 & Landfill complex asbestos operations \\
\hline CFA-104 & Area & 001 & $\begin{array}{l}\text { NEEL Landfill Complex } \\
\text { commercial/industrial waste operations }\end{array}$ \\
\hline CFA-105 & Area & 001 & INEEL Landfill Complex Land-farming Ops \\
\hline CFA-609 & Security Headquarters & 001 & $166 \mathrm{hp} \mathrm{standby} \mathrm{generator}$ \\
\hline CFA-609 & Security Headquarters & 002 & 50 gal indoor diesel tank \\
\hline CFA-609 & Security Headquarters & 017 & 15 gal weapon cleaning solvent tank \\
\hline CFA-612 & Industrial Hygiene Lab & 007 & Nonradiological analysis instrument exhaust \\
\hline CFA-612 & Industrial Hygiene Lab & 008 & Nonradiological analysis fume hood \\
\hline CFA-612 & Industrial Hygiene Lab & 010 & Nonradiological analysis fume hood \\
\hline CFA-612 & Industrial Hygiene Lab & 012 & Nonradiological analysis fume hood \\
\hline CFA-622 & Craft shop & $\begin{array}{l}009,015 \\
019,020 \\
021\end{array}$ & Welding shop \\
\hline CFA-623 & Craft shop & 005 & Paint Shop Solvent Distillation \\
\hline CFA-623 & Craft Shop & 017 & Paint Booth \\
\hline CFA-625 & Environmental Chemistry Lab & 009 & $\begin{array}{l}\text { Nonradioactive emissions from lab fume } \\
\text { hoods }\end{array}$ \\
\hline CFA-633 & Gantry Crane & 091 & $110 \mathrm{hp}$ generator \\
\hline CFA-660 & Bus Driver Office & $\begin{array}{l}020,021 \\
022\end{array}$ & Propane Heaters \\
\hline CFA-666 & Fire Station & $\begin{array}{l}032,033 \\
034,035 \\
036,037 \\
038,039 \\
040,041\end{array}$ & Propane Heaters \\
\hline CFA-668 & Communications Bldg & 006 & $350 \mathrm{hp}$ standby generator \\
\hline
\end{tabular}


Table 6. Not significant sources at CFA.

\begin{tabular}{|c|c|c|c|}
\hline $\begin{array}{l}\text { Building } \\
\text { number }\end{array}$ & Building Name & $\begin{array}{l}\text { Vent } \\
\text { number }\end{array}$ & $\begin{array}{l}\text { Source } \\
\text { description }\end{array}$ \\
\hline CFA-675 & Generator Bldg & 002 & $150 \mathrm{hp}$ standby generator \\
\hline CFA-679 & Firehouse Generator Bldg & 007 & $60 \mathrm{hp}$ standby generator \\
\hline CFA-688 & Engineering Technical Center & 002 & Technical welding \\
\hline CFA-688 & Engineering Technical Center & 047 & $100 \mathrm{hp}$ standby generator \\
\hline CFA-689 & Environmental Sampling Lab & 034 & Sample preparation laboratory \\
\hline CFA-690 & RESL & All & $\begin{array}{l}\text { Environmental laboratory instrument and } \\
\text { fume hood exhaust stacks }\end{array}$ \\
\hline CFA-696 & Vehicle service & 001 & $1 \mathrm{MBtu} / \mathrm{hr}$ steam cleaner \\
\hline CFA-696 & Vehicle service & 002 & $1 \mathrm{MBtu} / \mathrm{hr}$ steam cleaner \\
\hline CFA-696 & Vehicle shop & 003 & Vehicle repair paint shop \\
\hline CFA-696 & Transportation Complex & $\begin{array}{l}006,007 \\
008,009 \\
010,011 \\
012,040\end{array}$ & $\begin{array}{l}\text { Exhaust trunks from vehicle repair/ } \\
\text { maintenance }\end{array}$ \\
\hline CFA-698 & Standards \& Calibration Lab & 007,013 & Laboratory fume hoods \\
\hline CFA-696 & Transportation Complex & 021 & Engine dynamometer \\
\hline CFA-708 & Tank & 001 & 42,000 gal diesel No.2 AST tank \\
\hline CFA-738 & Tank & 001 & 2,500 gal diesel No. 2 tank \\
\hline CFA-739 & Tank & 001 & 2,500 gal diesel No. 2 tank \\
\hline CFA-749 & Tank & 001 & 10,000 gal waste oil tank \\
\hline CFA-792 & Transportation Complex & 001 & 2,500 gal oil UST \\
\hline CFA-793 & Transportation Complex & 001 & $2,500 \mathrm{gal}$ oil UST \\
\hline CFA-794 & Transportation Complex & 001 & 2,500 gal oil UST \\
\hline CFA-795 & Transportation Complex & 001 & 6,000 gal waste oil UST \\
\hline CFA-796 & Transportation Complex & 001 & 15,000 gal diesel UST \\
\hline CFA-797 & Transportation Complex & 001 & 15,000 gal diesel UST \\
\hline
\end{tabular}


Table 6. Not significant sources at CFA.

\begin{tabular}{|c|c|c|c|}
\hline $\begin{array}{l}\text { Building } \\
\text { number }\end{array}$ & Building Name & $\begin{array}{l}\text { Vent } \\
\text { number }\end{array}$ & $\begin{array}{l}\text { Source } \\
\text { description }\end{array}$ \\
\hline CFA-799 & Transportation Complex & 001 & 15,000 gal gasoline UST \\
\hline CFA-1603 & Firewater Pump Bldg & 001,002 & Two $196 \mathrm{hp}$ standby firewater pumps \\
\hline CFA-1603 & Firewater Pump Bldg & 003,004 & Two 300 gal diesel No. 2 supplying tanks \\
\hline CFA-1611 & Emergency Response Facility & 001 & Natural gas heat \\
\hline CFA-1611 & Emergency Response Facility & 002 & Natural gas heat \\
\hline CFA-1611 & Emergency Response Facility & 003 & Generator \\
\hline CFA-1611 & Emergency Response Facility & 004 & Natural gas radiant heat \\
\hline CFA-1611 & Emergency Response Facility & 005 & Natural gas radiant heat \\
\hline CFA-1611 & Emergency Response Facility & 006 & Natural gas radiant heat \\
\hline CFA-1611 & Emergency Response Facility & 007 & Natural gas radiant heat \\
\hline CFA-1611 & Emergency Response Facility & 008 & Natural gas heat \\
\hline CFA-1612 & Medical Facility & 001 & Natural gas heat \\
\hline CFA-1612 & Medical Facility & 002 & Natural gas heat \\
\hline CFA-1612 & Medical Facility & 003 & Medical decontamination room \\
\hline CFA-1701 & Tank & 001 & , 1,000 gal diesel No. 2 tank \\
\hline CFA-1702 & Tank & 001 & 12,000 gal diesel No. 2 tank UST \\
\hline CFA-1703 & Tank & 001 & 1,000 gal diesel No. 2 tank UST \\
\hline CFA-1704 & Tank & 001 & 15,000 gal JP-4 Tank \\
\hline CFA-1705 & Tank & 001 & 12,000 gal diesel No. 2 tank UST \\
\hline CFA-1706 & Tank & 001 & 25,000 gal diesel No. 2 tank UST \\
\hline CFA-1708 & Tank & 001 & 20,000 gal diesel No. 2 tank \\
\hline HPTF-601 & Howe Peak & 001 & $80 \mathrm{hp}$ standby generator \\
\hline
\end{tabular}




\subsubsection{Summary of CFA Emissions}

Totals of each of the nonradionuclide principal pollutant emissions from sources at CFA during 1998 are summarized in Table 7.

Table 7. Summary of nonradionuclide principal pollutants at CFA.

\begin{tabular}{lll}
\hline Pollutant & \multicolumn{2}{c}{ Emissions } \\
& $\begin{array}{l}\text { Hourly } \\
\mathrm{lb} / \mathrm{hr}\end{array}$ & $\begin{array}{l}\text { Annual } \\
\text { ton/yr }\end{array}$ \\
\hline Carbon monoxide & $2.2 \mathrm{E}-01$ & $4.6 \mathrm{E}-01$ \\
Nitrogen oxides & $7.2 \mathrm{E}-01$ & $3.1 \mathrm{E}+00$ \\
PM-10 & $4.1 \mathrm{E}+01$ & $4.2 \mathrm{E}+01$ \\
Sulfur oxides & $5.1 \mathrm{E}+00$ & $1.3 \mathrm{E}+01$ \\
VOC - nonmethane & $7.2 \mathrm{E}-02$ & $1.6 \mathrm{E}+00$ \\
\hline
\end{tabular}

\subsubsection{Summary of CFA Changes}

Changes to specific sources located at CFA between the 1997 and 1998 Air Emissions Inventories are summarized in Table 8 . Justification to changes are provided to clarify the status of the source based on the following:

$$
\text { Insignificant (317.a) - No AEI listing }
$$

Not Significant (317.b) - AEI listing of vent/stack number only (labs included as not significant) Storage tanks, paint shop and weld shop are calculated as a group in Chapter 4 or the AEI. 
Table 8. Summary of source changes at CFA - 1997 to 1998 inventory.

\begin{tabular}{|c|c|c|c|}
\hline $\begin{array}{l}\text { Emission } \\
\text { Source }\end{array}$ & Source Type & $\begin{array}{l}1998 \\
\text { Changes }\end{array}$ & Description \\
\hline CFA-713-001 & Not Significant & Delete & Source removed from service during 1998 \\
\hline INEEL & Well drilling & Add & Category II Director's Exemption \\
\hline INEEL & $\begin{array}{l}\text { Diesel Engine } \\
\text { Well sampling }\end{array}$ & Add & $\begin{array}{l}\text { (3) } 66 \mathrm{hp} \text { diesel engine generators, } 1,920 \\
\text { hours operation a year (APAD \# 98-101) }\end{array}$ \\
\hline INEEL & Diesel Engine & Add & $\begin{array}{l}420 \text { hp diesel rock crusher (APAD \# 98- } \\
096 \text { ) }\end{array}$ \\
\hline INEEL & $\begin{array}{l}\text { Monitoring Well } \\
\text { at WAG-7 }\end{array}$ & Add & Fugitive dust emissions (APAD \# 99-010) \\
\hline INEEL & Fugitive dust & Add & Drilling 2 core holes (APAD \# 98-064) \\
\hline CFA & $\begin{array}{l}\text { Diesel Engine } \\
\text { Tests }\end{array}$ & Add & Category II Exemption (APAD \# 98-053) \\
\hline CFA-1707-001 & Not Significant & Delete & Source removed from service during 1998 \\
\hline
\end{tabular}




\subsection{Idaho Nuclear Technology and Engineering Center}

\subsubsection{Area Description}

INTEC was originally constructed in 1953 as an engineering-scale demonstration facility to process highly enriched spent reactor fuel. The plant became the INEEL's principal facility for receiving, storing, reprocessing, and managing nuclear materials from test, defense, and research reactors in the United States and other countries. Since 1963, the INTEC has converted more than six million gallons of radioactive liquid waste to granular solid form: In 1992 reprocessing of spent nuclear fuel was stopped. Currently, INTEC has several primary functions, including fuel storage, waste management, technical support, and utilities. Figure 8 shows a plot plan of INTEC.

Fuel receipt and storage areas include the Fuel Receiving and Storage Building (CPP-603), the Fluorinel Dissolution Process and Fuel Storage (FAST) facility (CPP-666), and the Peach Bottom Fuel Storage Facility (CPP-749). CPP-666 stores fuels in water pools, and CPP-749 stores the fuel rods in underground dry containment. CPP-603 houses fuels in both dry and underwater storage.

Waste management facilities manage liquid, solid, and gaseous radioactive wastes. Waste management facilities include the tank farm, CPP-604, CPP-605/649, CPP-659, and the calcine storage bin sets. The tank farm area consists of large storage tanks that store liquid radioactive waste before it is sent to CPP-659. CPP-659, the New Waste Calcining Facility (NWCF), is a process building used to decontaminate equipment, reduce the volume of radioactive liquid wastes and convert radioactive liquid waste into a more stable solid radioactive waste called calcine. The calcine is then temporarily stored in storage bins until final treatment and disposal of the waste. CPP-604 houses the process equipment waste evaporators that concentrate dilute low-level radioactively contaminated liquid waste. The atmospheric protection system filters process offgas and process ventilation through banks of HEPA filters.

Technical facilities provide for chemical, radiochemical, and spectroscopic analysis and process development. Those facilities include the remote analytical facility (CPP-627), the Remote Analytical Laboratory (CPP-684), the process improvement facility (CPP-637), the process building (CPP-601), the laboratory and office building (CPP-602), and the safety and spectrometry building (CPP-630). 


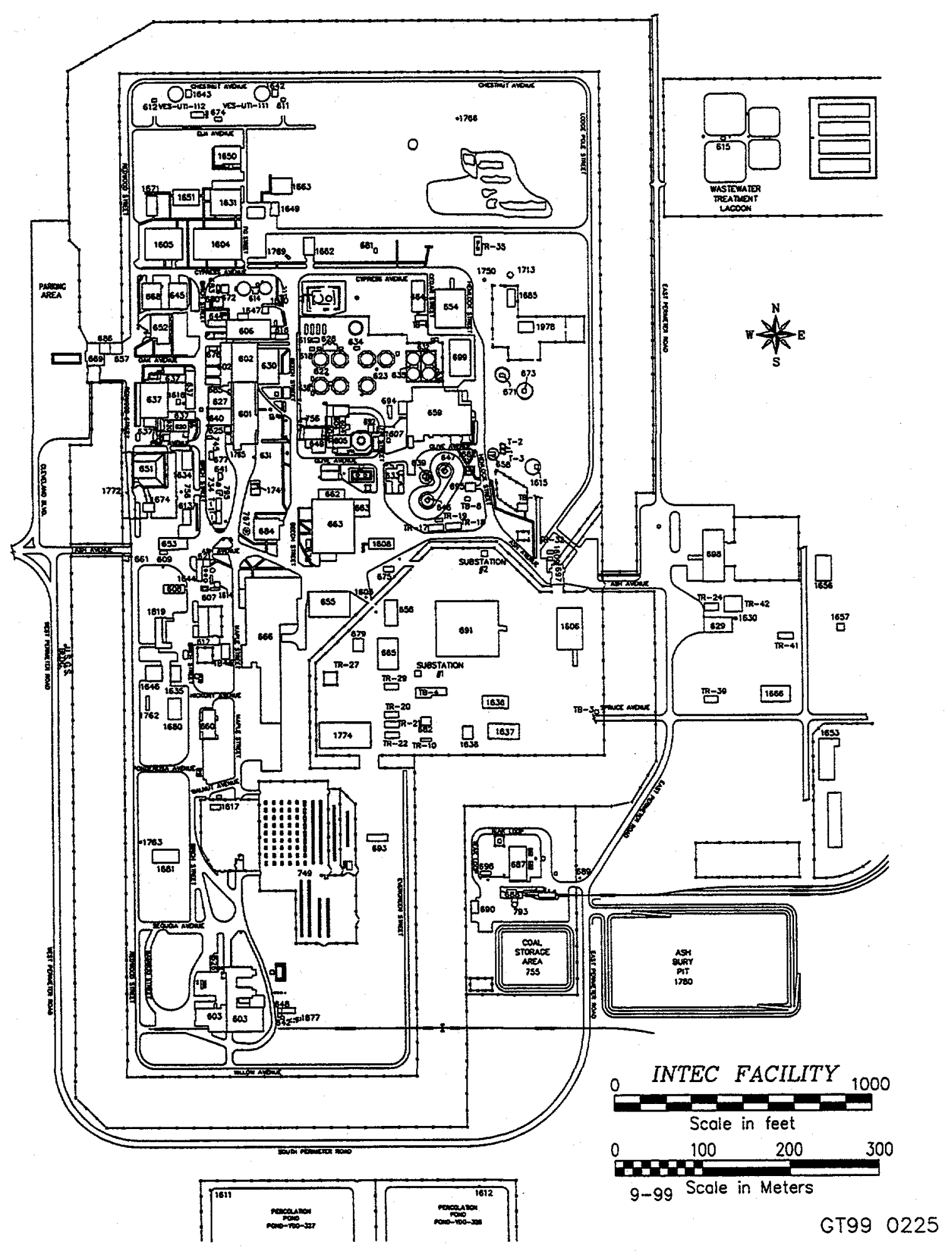

Figure 8. Area plot plan of the Idaho Nuclear Technology and Engineering Center. 


\subsubsection{Significant Source Description}

The Remote Analytical Laboratory (CPP-684) is used for chemical analysis of samples generated at various areas throughout INTEC. Some of those areas include the FAST facility (CPP-666), the process building (CPP-601), the service waste system, various pilot plants, the decontamination facility, Tank Farm Tanks and NWCF. The building consists of radioactive and nonradioactive laboratories, offices, and other support space. The facility was designed to segregate work areas. (RAL has both significant and not significant emissions so it is listed in both groups.)

The warm (slightly radioactive) laboratory area receives filtered air from the heating, ventilating, and air conditioning air supply room as four separate streams. These streams flow to the following areas (some of which may be slightly radioactive): offices, change rooms, operating gallery, and maintenance corridor; valve room and operating gallery; and the warm (radioactive) laboratory. Total flow through these areas is about $16,000 \mathrm{cfm}$, and the flow goes from the least contaminated to the most contaminated areas. These streams are combined and exhausted through a double HEPA filter to the warm laboratory exhaust stack. The warm exhaust stream is sampled and monitored for radioactive material.

The cold (nonradioactive) laboratory system is supplied by two filtered streams. One stream supplies the vestibule, offices, sample data room, and toilets. The other stream supplies the cold laboratories. The laboratory stream, with a flow of about $4680 \mathrm{cfm}$, discharges unfiltered through the cold laboratory exhaust stack. The other stream, with a volume of $530 \mathrm{cfm}$, exhausts through the office area exhaust blower. As a chemical laboratory, a large variety of chemicals are used in the facility. Most of these are liquid and are used in small quantities. Organic chemicals that are sometimes used in the area include propane used as a laboratory fuel supply, isopropanol used for cleaning equipment, and methyl isobutyl ketone used as an extractant. Inorganic materials that could be present include boron, cadmium, mercury, chromium, hydrofluoric acid, and nitric acid.

INTEC, like other industrial plants, uses steam for a variety of purposes, including heating and other process needs. CFSGF is the primary facility at INTEC for generating this steam, with other oil-fired boilers used as backup. This facility had a PSD permit before construction began.

CFSGF has two fluidized bed boilers that burn coal to provide the heat to generate steam. This burning process generates unburned organics, particulates, sulfur oxides, nitrogen oxides, and other materials that are, after appropriate cleanup, discharged to the atmosphere. The facility consists of the two boilers and associated equipment such as coal unloading and handling facilities, an ash pit, and other items necessary to operate the facility. Particulates are removed by passing the offgas through bag filters, and a limestone injection system is used to remove most of the sulfur that is generated during the burning of the coal.

CFSGF has a design heat generation rate of $165 \mathrm{MBtu}$ per hour. The design coal consumption rate is $16,500 \mathrm{lb} / \mathrm{hr}$. At this rate, $135,000 \mathrm{lb}$. of steam are generated per hour. Offgases from the coal combustion discharge through a dedicated stack that is $150 \mathrm{ft}$ high and about $5.8 \mathrm{ft}$ in diameter. The effluent discharges at a temperature of $350^{\circ} \mathrm{F}$ and at a flow rate of $75,000 \mathrm{cfm}$, resulting in a velocity of approximately $47 \mathrm{ft} / \mathrm{sec}$. 
CPP-606, the Service Building Power House, houses four oil fired boilers used as backup for the CFSGF. The boilers in CPP-606 are considered primary sources even though they are standby boilers. The four boilers consist of two Babcock \& Wilcox Company boilers, one Murray boiler, and one Cleaver Brooks boiler. These boilers have been included in the PSD permit for the INTEC $N_{\mathrm{x}}$ sources. There are only three stacks for all four boilers because the two Babcock \& Wilcox Company boilers share a common stack.

The FAST facility (CPP-666) is a primary facility at INTEC for storing nuclear fuel. Fuel received from other locations is brought to the FAST facility in large, shielded casks, where it is unloaded and stored in large water-filled basins.

The Fuel Storage Area consists of a truck receiving area, a cask receiving area, decontamination rooms, a fuel unloading area, and a water treatment area in addition to the fuel storage area. The decontamination area is used to remove any surface contamination that may be present on the cask. The flourinel dissolution process area contains the cells where the fuel dissolution occurred, as well as change rooms, offices and the control room, a chemical makeup area, and other support areas. Both areas share one overall ventilation system that discharges to a special, dedicated FAST stack located north of the building. This stack is approximately $160 \mathrm{ft}$ high. A bypass is available if the stack or the line leading to it becomes inoperable. The bypass is located on the roof of the CPP-666 near the northwest corner. Total flow through the ventilation system is about 90,700 actual cubic feet per minute.

All gaseous effluents at FAST, both radiological and nonradiological, are routed through HEPA filters before discharging to the environment. In general, the offgas from each area is filtered through roughing and HEPA filters before it leaves the area. These streams are then combined with the general ventilation air, which is again filtered before releasing to the environment. The individual treatment of an offgas stream before it leaves an area is based on the knowledge of the process and potential contents of the stream, which determines the number of filter stages needed or if other cleanup equipment is appropriate. The final cleanup system that treats the stream leaving the facility consists of four pairs of prefilters followed by HEPA filters. (The stream is split into four parts as it leaves the building.) Heat recovery coils are present to help conserve and recover heat from the exiting stream. The air stream then flows through a common duct to one of three blowers, each of which is sized to handle half of the total flow. The exhaust then flows through an underground duct to the FAST stack.

The INTEC main stack is the primary emission point at INTEC because of the volume of gas discharged and the contaminants released. The main stack is $250 \mathrm{ft}$ tall and has a diameter of about $6.5 \mathrm{ft}$. Air flow through the stack is about 100,000 to $150,000 \mathrm{cfm}$, resulting in a velocity up the stack of about $61 \mathrm{ft} / \mathrm{sec}$. Offgas release points from throughout the INTEC area are collected and lead to the main stack where the emissions are monitored, sampled, and released to the environment. The streams leading to the main stack can be classified according to their origin as well as the activities from which they come. The effluent from the main stack is constantly monitored for the primary emissions, specifically nitrogen oxides and radionuclides. Releases of nitrogen oxides and radionuclides from the main stack are regulated by the INTEC NO ${ }_{\mathrm{X}}$ Sources Permit to Construct issued by the State of Idaho.

Although a large number of activities are conducted at INTEC, the primary sources that generate emissions are classified as a) nuclear fuel storage, b) treatment of the waste generated during dissolution by converting it from a liquid to a solid in a process called calcination, $c$ ) treatment of other waste streams 
by evaporation, d) sampling of many of the liquid streams, and e) various support activities involving chemical analysis, process development, steam generation, and other activities associated with operation of the plant.

These activities are reflected in the design of the system that collects offgases for transport to and release from the main stack. This system collects offgases from the following areas: a) general ventilation air from buildings CPP-601, CPP-602, CPP-604, CPP-633, CPP-627, and CPP-640;

b) dissolver offgas lines that collected the offgases that are generated during the fuel dissolution process;

c) sample offgas lines that collect emissions generated when samples are obtained by using air or steam jets to obtain samples from various tanks or lines; d) vessel offgas lines that are connected to many vessels in all parts of the plant and generate offgases as they are filled or breathe; and e) and process offgas lines from the calcination process that are high in nitrogen oxides because of the destruction of the nitrate present in the wastes, which occurs during the calcination process.

The general ventilation air typically contains only minor quantities of pollutants which come from areas that under normal circumstances do not contain hazardous materials and that are normally occupied. Air from hoods, normally radioactive areas, and similar areas is not included in the normal ventilation air. This air, like all releases to the INTEC main stack, is processed through the Atmospheric Protection System before being released to the environment.

Releases to the main stack are highly dependent on the individual activities that are in operation at the time, and these can vary greatly over the years or throughout any given year. Operation of the calciner at NWCF results in large quantities of nitrogen oxides being released; nitrogen oxide releases are minimal when the calciner is not operating.

Certain materials considered toxic by the State of Idaho could be present in the gas exhausted from the main stack. Because of the extensive cleanup system present on the offgas stream, most or all of these substances would be present in concentrations significantly below the levels considered as toxic by the State of Idaho. Laboratory ventilation air discharges to this system, and this air could contain minute quantities of the many chemicals typically used in a laboratory, although these chemicals would normally be used only in a hood with a separate discharge point. Some of the toxic materials that could be present in the exhaust in small quantities include acetic acid, cadmium compounds, sulfuric acid, various solvents, tributyl phosphate, aluminum nitrate, ammonia, barium compounds, borates, chromium compounds, fluorides, formic acid, hydrochloric acid, nitric acid, oxalic acid, sodium hydroxide, mercury, chlorine and uranium and zirconium compounds.

\subsubsection{Not Significant Sources}

INTEC contains the most secondary sources of any area at the INEEL. Secondary sources at INTEC include organic and inorganic storage tanks, several propane burners, large engines, small engines, and chemical sources. Chemical sources encompass numerous fumehoods, chemical processes, blueprint machines, and painting operations.

There are also several miscellaneous sources such as chemical pumps and lines and potential sources of radionuclides (i.e., the INTEC percolation ponds). Most of these sources contribute very small quantities of air pollutants and have little impact on air quality. 
Table 9. Not significant emission sources at INTEC.

\begin{tabular}{|c|c|c|c|}
\hline $\begin{array}{l}\text { Building } \\
\text { number }\end{array}$ & Building name & $\begin{array}{l}\text { Vent } \\
\text { number }\end{array}$ & Source description \\
\hline CPP-012 & Service & 001 & 8,000 gal sulfuric acid outdoor tank \\
\hline \multirow[t]{3}{*}{ CPP-601 } & Fuel Process & 009 & 312 gal ammonium hydroxide indoor tank \\
\hline & & 014 & $\begin{array}{l}1,000 \text { gal nitric acid indoor tank and several } \\
\text { aluminum nitrate indoor tanks }\end{array}$ \\
\hline & & 024 & 1,700 gal hexone indoor tank \\
\hline CPP-602 & Laboratory & $\begin{array}{l}012,014 \\
031\end{array}$ & Laboratory \\
\hline CPP-603 & Fuel Storage & 008 & $150 \mathrm{hp}$ propane generator \\
\hline CPP-604 & Waste Treatment & 011 & Decon tank \\
\hline CPP-606 & Service & 038 & 3 separate storage indoor tanks for inorganics \\
\hline CPP-606 & & 013 & 5 separate storage tanks for inorganics \\
\hline CPP-614 & Pump house & $\begin{array}{l}001 \\
002\end{array}$ & $\begin{array}{l}300 \text { gal diesel indoor tank } \\
300 \mathrm{hp} \mathrm{diesel} \mathrm{fire} \mathrm{pump}\end{array}$ \\
\hline CPP-616 & Compressor Bldg & 004 & $360 \mathrm{hp} \mathrm{diesel} \mathrm{air} \mathrm{compressor}$ \\
\hline CPP-621 & Pump house & 003 & Electric pumps \\
\hline CPP-627 & Laboratory & $\begin{array}{l}007,008 \\
010,013 \\
016\end{array}$ & Laboratories \\
\hline CPP-630 & Laboratory & 011,012 & Laboratories \\
\hline CPP-637 & $\begin{array}{l}\text { Process Improvement } \\
\text { Facility }\end{array}$ & $\begin{array}{l}010 \\
021 \\
063 \\
064\end{array}$ & $\begin{array}{l}\text { Laboratory } \\
\text { Propane burner } \\
500 \text { gal kerosene outdoor tank } \\
\text { Laboratory }\end{array}$ \\
\hline CPP-644 & Emergency Power Bldg & $\begin{array}{l}002 \\
004 \\
005 \\
006 \\
013\end{array}$ & $\begin{array}{l}2,000 \mathrm{hp} \text { diesel generator } \\
5.4 \text { gal gasoline indoor tank } \\
14 \mathrm{hp} \text { gasoline air compressor } \\
\text { two } 50 \text { gal diesel indoor tanks } \\
3,000 \text { gal diesel outdoor tank }\end{array}$ \\
\hline CPP-654 & Warehouse & 007,008 & Propane unit heaters \\
\hline
\end{tabular}


Table 9. Not significant emission sources at INTEC.

\begin{tabular}{|c|c|c|c|}
\hline $\begin{array}{l}\text { Building } \\
\text { number }\end{array}$ & Building name & $\begin{array}{l}\text { Vent } \\
\text { number }\end{array}$ & Source description \\
\hline & & $\begin{array}{l}009,010 \\
011,012\end{array}$ & $<300,000 \mathrm{MBtu} / \mathrm{hr}$ \\
\hline CPP-655 & Warehouse & $\begin{array}{l}018,019 \\
026,028 \\
030,031\end{array}$ & $\begin{array}{l}\text { Propane unit heaters } \\
<300,000 \mathrm{Btu} / \mathrm{hr}\end{array}$ \\
\hline \multirow[t]{3}{*}{ CPP-659 } & NWCF Substation & 006 & $1,614 \mathrm{hp} \mathrm{diesel} \mathrm{generator}$ \\
\hline & & 007 & $8 \mathrm{hp}$ gasoline air compressor \\
\hline & & 008 & 1,614 hp diesel generator \\
\hline \multirow[t]{4}{*}{ CPP-659 } & NWCF & 010,011 & Two 5,000 gal diesel underground tanks \\
\hline & & 025 & Two 1,290 gal kerosene tanks \\
\hline & & 033 & HVAC, Hot cells, tank \\
\hline & & 036 & Decon HVAC \\
\hline CPP-662 & Maintenance Shop & 003,004 & Welding booths \\
\hline CPP-663 & & 002,045 & Welding booths \\
\hline CPP-663 & & 048,049 & Paint booth \\
\hline CPP-663 & & 054 & Paint fumehood \\
\hline CPP-679 & Craft shop & 002,003 & Propane unit heaters $<300,000 \mathrm{Btu} / \mathrm{hr}$ \\
\hline CPP-684 & Remote Analytical Lab & 001,008 & Laboratories \\
\hline \multirow[t]{3}{*}{ CPP-687 } & $\begin{array}{l}\text { Coal Fired Steam } \\
\text { Generator Facility }\end{array}$ & 026 & $2,535 \mathrm{hp} \mathrm{diesel} \mathrm{generator}$ \\
\hline & & 050 & $14 \mathrm{hp}$ diesel air compressor \\
\hline & & 044 & Three 50 gal tanks for inorganics \\
\hline CPP-694 & Tank Containment & 007 & 4,600 gal spent solvent tank \\
\hline CPP-694 & & 008,010 & Two 7,500 gal spent solvent tanks \\
\hline \multirow[t]{2}{*}{ CPP-698 } & MK Complex & 004,006 & Welding booths \\
\hline & & $\begin{array}{l}009,010 \\
016,017 \\
018\end{array}$ & $\begin{array}{l}\text { Propane unit heaters } \\
<300,000 \mathrm{Btu} / \mathrm{hr}\end{array}$ \\
\hline CPP-701A & Storage Tank & 001 & 240,000 gal diesel outdoor tank \\
\hline $\mathrm{CPP}-701 \mathrm{~B}$ & Storage Tank & 001 & 50,000 gal diesel outdoor tank \\
\hline
\end{tabular}


Table 9. Not significant emission sources at INTEC.

\begin{tabular}{llll}
\hline $\begin{array}{l}\text { Building } \\
\text { number }\end{array}$ & Building name & $\begin{array}{l}\text { Vent } \\
\text { number }\end{array}$ & Source description \\
\hline CPP-702A & Storage Tank & 001 & Two 20,000 gal kerosene outdoor tanks \\
CPP-702B & Storage Tank & 001 & \\
CPP-703 & Storage Tank & 001 & 2,500 gal diesel underground tank \\
CPP-703 & & 002 & 5,000 gal gasoline underground tank \\
CPP-719A & Acid Storage & 001 & 34,000 gal nitric acid outdoor tank \\
CPP-719B & Acid Storage & 001 & 18,400 gal nitric acid outdoor tank \\
CPP-720A & Storage & 001 & 16,000 gal aluminum nitrate outdoor tank \\
CPP-720B & Storage & 001 & Two 6,200 gal aluminum nitrate outdoor tanks \\
CPP-720C & Storage & 001 & \\
CPP-775 & Pump Shed & 005 & 1,500 gal diesel outdoor tank \\
CPP-798 & Storage & 001 & 160 gal hydrofluoric acid outdoor tank \\
CPP-1642 & Pump House & 003 & 500 gal diesel indoor tank \\
& & 007 & 370 hp diesel fire pump \\
CPP-1643 & Pump House & 003 & 500 gal diesel indoor tank \\
CPP-1760 & Kerosene Receiving & 001,002 & Kerosene Tank \\
CPP-T6 & Temporary Office & 001 & Propane unit heaters \\
& & 004 & $<300,000$ Btu/hr \\
\hline
\end{tabular}

\subsubsection{Summary of INTEC Emissions}

Totals of each of the nonradionuclide principal pollutant emissions from sources at INTEC during 1998 are summarized in Table 10. 
Table 10. Summary of nonradionuclide principal pollutants at INTEC.

\begin{tabular}{lcc} 
Pollutant & \multicolumn{2}{c}{ Emissions } \\
Hourly & $\mathrm{lb} / \mathrm{hr}$ & $\begin{array}{c}\text { Annual } \\
\text { ton/yr }\end{array}$ \\
\hline Carbon monoxide & $2.9 \mathrm{E}+02$ & $2.2 \mathrm{E}+02$ \\
Nitrogen oxides & $3.9 \mathrm{E}+02$ & $3.9 \mathrm{E}+02$ \\
PM-10 & $2.2 \mathrm{E}+00$ & $1.7 \mathrm{E}+00$ \\
Sulfur oxides & $1.4 \mathrm{E}+02$ & $7.7 \mathrm{E}+01$ \\
VOC - nonmethane & $1.0 \mathrm{E}+01$ & $1.4 \mathrm{E}+01$ \\
\hline
\end{tabular}

\subsubsection{Summary of INTEC changes}

There were some modifications or changes to a few air emissions sources at INTEC in 1998. These changes are listed in Table 11.

Table 11. Changes to air emission sources at INTEC for 1998.

Area Description

CPP-603 IFSF Fuel Canning Operation The modification will not increase air emissions (APAD \# 98-004)

CPP off gas characterization and treatment Emissions from the laboratory and pilot plant are development exempt (APAD \# 98-025)

CPP new equipment for corrosion and material studies

Air emissions of sodium chloride are not regulated by State or Federal air regulations (APAD \#98-082)

Corrosion studies

Air emissions consisting of sodium chloride will occur but are not regulated by State of Federal regulations (APAD \# 98-083)

There were no changes in 1998 to air emission sources that increased emissions and/or the emissions were exempt form State and Federal regulations. 


\subsection{Naval Reactors Facility}

\subsubsection{Area Description}

The Naval Reactors Facility (NRF), located in the west-central part of the INEEL site, is operated for the U.S. Naval Nuclear Propulsion Program by Bechtel Bettis, Incorporated, Bettis-Idaho. There are three main operational areas at NRF: the naval prototypes, the Expended Core Facility (ECF), and Site Services. An area plot plan of NRF is shown in Figure 9.

NRF previously operated three prototype plants as training platforms for U.S. Navy personnel. The S1W, A1W, and S5G prototypes were permanently shutdown in October of 1989, January of 1994, and May of 1995, respectively. The prototype operational area includes the three prototype plant buildings, chemistry laboratory facilities, multi-craft areas, office spaces, and numerous other support buildings and shops. Work in these areas consists of maintenance operations and defueling and inactivation of the AIW and the S5G prototype plants.

The ECF receives spent naval fuel and prepares it for shipment to the Idaho Nuclear Technology and Engineering Center (INTEC). In addition, ECF serves as a laboratory for examining, testing, and evaluating material specimens, fuel, and reactor components associated with the Naval Nuclear Propulsion Program. The ECF houses loading and unloading bays for shipping containers, reinforced concrete water pools for handling spent nuclear fuel, and shielded examination cells for testing individual specimens. The ECF building also includes multi-craft shops, chemical laboratory facilities, and office spaces. 


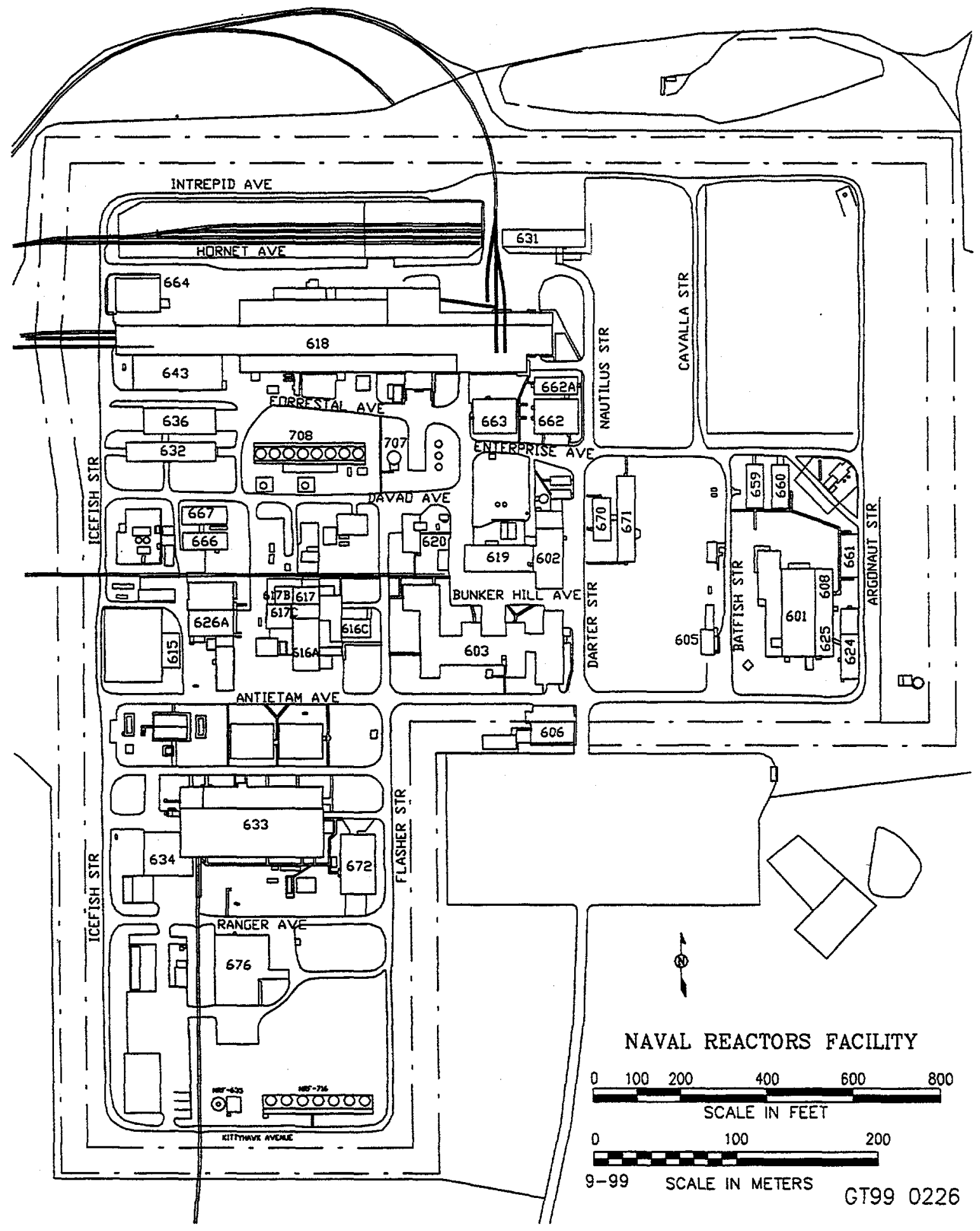

Figure 9. Area plot plan of the Naval Reactors Facility. 
Maintenance and support services for NRF operations are provided by Site Services which is centrally located on the NRF site. The multi-craft area includes facilities for machining, welding, painting, carpentry, and fabrication operations and provides most of the required nonradiological maintenance and repair services for the NRF site. All of the steam for space heating at NRF is produced in the Site Service's boiler house. Site Services is also responsible for operating emergency diesel equipment for preventive maintenance.

\subsubsection{Significant Sources}

Boiler operations account for most of the criteria pollutant emissions and represent the only nonradiological significant sources for NRF. The three NRF boilers (NRF-620-012, -013, -014) provide steam for space heating in most NRF buildings. The heating season typically runs from late September until early May, depending on seasonal variations. Normally, one boiler operates, one boiler remains in hot standby, and a third boiler is in a cold lay-up condition. Table 12 lists the significant sources at NRF.

Table 12. Significant emission sources at NRF.

\begin{tabular}{llll}
\hline Building Number & Building Name & Vent/Stack Number & Source Description \\
\hline NRF-620 & Boiler House & NRF-620-012 a,b & Boiler Exhaust Stack \\
NRF-620 & Boiler House & NRF-620-013 a & Boiler Exhaust Stack \\
NRF-620 & Boiler House & NRF-620-014 a & Boiler Exhaust Stack
\end{tabular}

a. This source has consumed PSD increment.

b. Emissions from all three boilers were placed under 620-012. This helped to prevent the system from zeroing very small emission numbers.

\subsubsection{Not Significant Sources}

NRF has a variety of not significant sources, including organic liquid storage tanks, fuel burning equipment, and chemical sources. Not significant fuel burning equipment includes stationary diesel engines used for emergency power production and emergency water pumping systems. The chemical sources include laboratory fumehoods and multi-craft shops and maintenance operations. Table 13 lists the not significant sources at NRF.

Site Services maintains the Power System Upgrade (PSU) emergency diesel power system (NRF-686), the emergency fire diesels, and the associated fuel tanks. In 1991, the PSU diesels consolidated most of NRF's emergency power generating capability into one system. Four identical, large, 1445-horsepower engines are housed in NRF-686. Site Services also maintains three small diesel engines as emergency fire pumps (NRF-602-005, 635-005 \& -007) and these are sited in various locations at NRF. Fuel tanks range from 216 gallon capacity, for supplying small engines, to 25,000 gallon capacity, for supplying the boilers and the PSU diesels. Primary pollutants from these sources include carbon monoxide, nitrogen oxides, and VOCs. Actual emissions are small because of the limited operating schedule. 
The Site Services multi-craft area contains several shops with VOC and particulate emissions. Some of the emissions associated with multi-craft operations occur in the shop areas, where prefabrication and preparatory work can be completed. However, the majority of air emissions result during the actual installation, maintenance, and repair activities which occur at various, on-location areas throughout NRF. To more accurately account for air pollutants released through these multi-craft and maintenance activities, all material usage and the associated emissions are attributed to two centrally located emission points, regardless of the physical location of the activities.

All paint usage is attributed to the designation NRF-PNT-ALL. This designation is used for reporting the VOC and particulate emissions for all paint usage: from spray booth operation (NRF-602006), from paint storage (NRF-633A-089), and from hand applications at locations throughout the NRF Site.

All other chemical emissions associated with multi-craft and maintenance operations are attributed to the designation NRF-MCM-ALL. This designation is used for reporting all hazardous air emissions from multi-craft activities, both in specific shop locations and at job locations throughout NRF. Emissions from non-exempt maintenance and process operations are also included under this designation.

In the prototype operational area, there are three sources of not significant emissions: the S5G Prototype building (NRF-633), the A1W Prototype building (NRF-616, NRF-617), and the S1W Prototype building (NRF-601). Not significant quantities of nonradioactive chemicals and fumes are emitted from these buildings from chemical laboratories and multi-craft activities associated with the defueling and inactivation operations and with maintenance and repair activities. The primary emissions for operations in the prototype area are VOCs and particulates, which are included under NRF-MCMALL for all multi-craft and maintenance operations.

The ECF building (NRF-618) contains a variety of not significant multi-craft and maintenance operations. Chemical and metallurgical laboratories, decontamination facilities, and various repair and refurbishment operations in the building utilize products containing hazardous air pollutants. The primary nonradioactive emissions are VOCs and particulates. These emissions are reported with other multicraft and maintenance operations under NRF-MCM-ALL.

Table 13. Not significant emission sources at NRF.

\begin{tabular}{|c|c|c|c|}
\hline $\begin{array}{l}\text { Building } \\
\text { number }\end{array}$ & Building name & Vent/stack number & Source description \\
\hline NRF-601 & S1W Main Building & NRF-601-019A & S1W Chemistry Laboratory \\
\hline NRF-601 & S1W Main Building & NRF-601-036 & $\begin{array}{l}\text { S1W Chemistry Laboratory Atomic } \\
\text { Absorption Vent }\end{array}$ \\
\hline NRF -602 & Site Services Building & NRF-602-005 c & $\begin{array}{l}\text { Fire Pump Emergency Diesel Genera- } \\
\text { tor (EDG) Exhaust; } 300 \mathrm{hp}\end{array}$ \\
\hline NRF-618 & Expended Core Facility & NRF-618-099 & ECF Chemistry Laboratory \\
\hline NRF-622 & Deep Well 3 Pump & NRF-622-001a & Well No. 3 Emergency Diesel Engine \\
\hline
\end{tabular}


Table 13. Not significant emission sources at NRF.

\begin{tabular}{|c|c|c|c|}
\hline $\begin{array}{l}\text { Building } \\
\text { number }\end{array}$ & Building name & Vent/stack number & Source description \\
\hline & House & & exhaust; $400 \mathrm{hp}$ \\
\hline NRF-635 & S5G Pump House & NRF-635-006 c & $\begin{array}{l}\text { Emergency Fire Pump Diesel Engine } \\
\text { Exhaust; } 220 \text { hp }\end{array}$ \\
\hline NRF-635 & S5G Pump House & NRF-635-007c & $\begin{array}{l}\text { Emergency Fire Pump Diesel Engine } \\
\text { Exhaust; } 220 \mathrm{hp}\end{array}$ \\
\hline NRF-636 & Component Warehouse & NRF-636-008 & Degreasing Bath \\
\hline NRF-636 & Component Warehouse & $\begin{array}{l}\text { None-no vents in } \\
\text { this part of } \\
\text { building }\end{array}$ & Portable Fluorescent Lamp Crusher \\
\hline NRF-686 & $\begin{array}{l}\text { Diesel Generator } \\
\text { Facility }\end{array}$ & NRF-686-001 & $\begin{array}{l}\text { No. } 1 \text { PSU Diesel Fuel Day Tank } 216 \\
\text { gal }\end{array}$ \\
\hline NRF-686 & $\begin{array}{l}\text { Diesel Generator } \\
\text { Facility }\end{array}$ & NRF-686-002 & $\begin{array}{l}\text { No. } 2 \text { PSU Diesel Fuel Day Tank } 216 \\
\text { gal }\end{array}$ \\
\hline NRF-686 & $\begin{array}{l}\text { Diesel Generator } \\
\text { Facility }\end{array}$ & NRF-686-003 & $\begin{array}{l}\text { No. } 3 \text { PSU Diesel Fuel Day Tank } 216 \\
\text { gal }\end{array}$ \\
\hline NRF-686 & $\begin{array}{l}\text { Diesel Generator } \\
\text { Facility }\end{array}$ & NRF-686-004 & $\begin{array}{l}\text { No. } 4 \text { PSU Diesel Fuel Day Tank } 216 \\
\text { gal }\end{array}$ \\
\hline NRF-686 & $\begin{array}{l}\text { Diesel Generator } \\
\text { Facility }\end{array}$ & NRF-686-016a & No. 3 PSU EDG Exhaust; 1,445 hp \\
\hline NRF-686 & $\begin{array}{l}\text { Diesel Generator } \\
\text { Facility }\end{array}$ & NRF-686-017a & No. 4 PSU EDG Exhaust; 1,445 hp \\
\hline NRF-686 & $\begin{array}{l}\text { Diesel Generator } \\
\text { Facility }\end{array}$ & NRF-686-018a & No. 1 PSU EDG Exhaust; 1,445 hp \\
\hline NRF-686 & $\begin{array}{l}\text { Diesel Generator } \\
\text { Facility }\end{array}$ & NRF-686-019a & No. 2 PSU EDG Exhaust; 1,445 hp \\
\hline NRF-711A & Fuel Oil Storage Tank & NRF-711A-001b,c & $\begin{array}{l}\text { Boiler House Fuel Storage Tank; } \\
25,000 \text { gal }\end{array}$ \\
\hline NRF-711B & Fuel Oil Storage Tank & NRF-711B-001b,c & $\begin{array}{l}\text { Boiler House } \\
\text { Fuel Storage Tank; } 25,000 \mathrm{gal}\end{array}$ \\
\hline NRF-711C & Fuel Oil Storage Tank & NRF-711C-001b,c & $\begin{array}{l}\text { Boiler House } \\
\text { Fuel Storage Tank; } 25,000 \text { gal }\end{array}$ \\
\hline NRF -718 & $\begin{array}{l}\text { Plant Services Diesel } \\
\text { Fuel Tank }\end{array}$ & NRF-718-001 c & $\begin{array}{l}\text { Fire Pump EDG Fuel Oil Tank; } 500 \\
\text { gal }\end{array}$ \\
\hline NRF-727 & Diesel Fuel Tank & NRF-727-001 & $\begin{array}{l}\text { Well No. } 3 \text { Emergency Diesel Engine } \\
\text { Fuel Oil Tank; 3,000 gal }\end{array}$ \\
\hline
\end{tabular}


Table 13. Not significant emission sources at NRF.

\begin{tabular}{|c|c|c|c|}
\hline $\begin{array}{l}\text { Building } \\
\text { number }\end{array}$ & Building name & Vent/stack number & Source description \\
\hline NRF-728 & $\begin{array}{l}\text { S5G Pump House } \\
\text { Diesel Fuel Tank }\end{array}$ & NRF-728-008 c & $\begin{array}{l}\text { Emergency Fire Pump Diesel Engine } \\
\text { Fuel Oil Tank; } 500 \text { gal }\end{array}$ \\
\hline NRF-737 & Bilge Waste Oil Tank & NRF-737-001 & Used Oil Collection Tank; 2,200 gal \\
\hline NRF-739 & $\begin{array}{l}\text { LDHR Diesel Fuel Oil } \\
\text { Storage Tank }\end{array}$ & NRF-739-001 d & $\begin{array}{l}\text { LDHR Diesel Fuel Oil Storage Tank; } \\
\text { 12,000 gal }\end{array}$ \\
\hline NRF-739 & $\begin{array}{l}\text { LDHR Diesel Fuel Oil } \\
\text { Storage Tank }\end{array}$ & NRF-739-002d & $\begin{array}{l}\text { LDHR Diesel Fuel Oil Storage Tank; } \\
\text { 12,000 gal }\end{array}$ \\
\hline NRF-745 & $\begin{array}{l}\text { Sulfuric Acid Tank } \\
\text { (south tank) }\end{array}$ & NRF-745-001C & Sulfuric Acid Storage Tank; 6,800 gal \\
\hline NRF-745 & $\begin{array}{l}\text { Sodium Hydroxide Tank } \\
\text { (north tank) }\end{array}$ & NRF-745-002c & $\begin{array}{l}\text { Sodium Hydroxide Storage Tank; } \\
6,800 \text { gal }\end{array}$ \\
\hline NRF-759A & $\begin{array}{l}\text { PSU Diesel Fuel Tank } \\
\text { East }\end{array}$ & NRF-759A-001b,e & East PSU Diesel Fuel Tank 25,000 gal \\
\hline NRF-759B & $\begin{array}{l}\text { PSU Diesel Fuel Tank } \\
\text { West }\end{array}$ & NRF-759B-001b,e & $\begin{array}{l}\text { West PSU Diesel Fuel Tank; } 25,000 \\
\text { gal }\end{array}$ \\
\hline NRF-769 & $\begin{array}{l}\text { Used Oil Storage } \\
\text { Facility }\end{array}$ & NRF-769-001 & Used Oil Storage Tank $1 ; 1,000$ gal \\
\hline NRF-769 & $\begin{array}{l}\text { Used Oil Storage } \\
\text { Facility }\end{array}$ & NRF-769-002 & Used Oil Storage Tank $2 ; 1,000$ gal \\
\hline NRF-773 & $\begin{array}{l}\text { Boiler House Fuel Oil } \\
\text { Storage Tank }\end{array}$ & NRF-773-001 & Fuel Oil Storage Tank 25,000 gal \\
\hline NRF-773 & $\begin{array}{l}\text { Boiler House Fuel Oil } \\
\text { Storage Tank }\end{array}$ & NRF-773-002 & Fuel Oil Storage Tank 25,000 gal \\
\hline NRF-774 & $\begin{array}{l}\text { Boiler House Propane } \\
\text { Tank }\end{array}$ & NRF-774-001 & Propane Tank $300 \mathrm{gal}$ \\
\hline NRF-MCM & $\begin{array}{l}\text { Multi-Craft Shops and } \\
\text { Maintenance Operations }\end{array}$ & NRF-MCM-ALL & $\begin{array}{l}\text { Multi-craft Shops and Maintenance } \\
\text { Operations }\end{array}$ \\
\hline NRF-PNT & $\begin{array}{l}\text { Paint Shops and Painting } \\
\text { Operations }\end{array}$ & NRF-PNT-ALL & $\begin{array}{l}\text { Paint Shops and other Painting } \\
\text { Operations }\end{array}$ \\
\hline NRF-PRT & Portable Heater & NRF-PRT-001 & $\begin{array}{l}\text { NNRS Ultramatic VI Portable Fuel Oil } \\
\text { Heater }\end{array}$ \\
\hline NRF-PRT & Portable Heater & NRF-PRT-002 & $\begin{array}{l}\text { NNRS Ultramatic VI Portable Fuel Oil } \\
\text { Heater }\end{array}$ \\
\hline NRF-PRT & Portable Fuel Storage & NRF-PRT-003 & White Portable Fuel Storage Tank; 500 \\
\hline
\end{tabular}


Table 13. Not significant emission sources at NRF.

\begin{tabular}{llll}
\hline $\begin{array}{l}\text { Building } \\
\text { number }\end{array}$ & Building name & Vent/stack number & Source description \\
\hline NRF-PRT & $\begin{array}{l}\text { Tank } \\
\begin{array}{l}\text { Portable Fuel Storage } \\
\text { Tank }\end{array}\end{array}$ & NRF-PRT-004 & $\begin{array}{l}\text { gal } \\
\text { Black Portable Fuel Storage Tank; 500 } \\
\text { gal }\end{array}$ \\
NRF-PRT & Portable Air Compressor & NRF-PRT-005 & $\begin{array}{l}\text { Portable Air Compressor, Diesel } \\
\text { Engine, 216 hp }\end{array}$ \\
NRF-PRT & Portable Heater & NRF-PRT-006c & \begin{tabular}{l} 
Portable Propane Heater \\
\hline
\end{tabular}
\end{tabular}

a. This source has consumed PSD increment.

b. This source consumes PSD increment but has not been included in a PSD analysis, It will be included in the next required PSD analysis.

c. This source was removed in 1998

d. These tanks were moved and renamed PSU Diesel Fuel Tanks East and West (NRF-759A-001 and NRF-759B-001).

e. These tanks were replaced with the two 12,000 gallon LDHR Diesel Fuel Oil Storage Tanks (NRF-739-001 and NRF-739-002). These tanks were moved and renamed Boiler House Fuel Oil Storage Tanks (NRF-773-001 and NRF-773-002).

\subsubsection{Summary of NRF Emissions}

Totals for each of the principal pollutant emissions from all sources at NRF during 1998 are summarized in Table 14.

Table 14. Summary of nonradionuclide pollutants from all sources at NRF.

\begin{tabular}{lcc} 
Pollutant & \multicolumn{2}{c}{ Emissions } \\
Hourly & An/hr & $\begin{array}{c}\text { Annul } \\
\text { ton/yr }\end{array}$ \\
\hline Carbon monoxide & $4.4 \mathrm{E}+01$ & $1.7 \mathrm{E}+00$ \\
Nitrogen oxides & $1.8 \mathrm{E}+02$ & $6.5 \mathrm{E}+00$ \\
PM-10 & $4.3 \mathrm{E}+00$ & $6.3 \mathrm{E}-01$ \\
Sulfur oxides & $3.6 \mathrm{E}+00$ & $5.4 \mathrm{E}+00$ \\
VOC - nonmethane & $2.3 \mathrm{E}+00$ & $8.3 \mathrm{E}-01$
\end{tabular}

\subsubsection{Summary of NRF Changes}

The two 12,000 gallon LDHR Diesel Fuel Oil Storage Tanks (NRF-739-001 and NRF-739-002) were moved and renamed PSU Diesel Fuel Tanks East and West (NRF-759A-001 and NRF-759B-001). 
The two 25,000 gallon former PSU Diesel Fuel Tanks were moved and renamed Boiler House Fuel Oil Storage Tanks (NRF-773-001 and NRF-773-002). The following sources were removed:

- NRF-602-005 Fire pump emergency generator, $300 \mathrm{hp}$

- NRF-635-006 Fire pump diesel engine, $220 \mathrm{hp}$

- NRF-635-007 Fire pump diesel engine, $220 \mathrm{hp}$

- NRF-711A-001 Boiler house fuel storage tank, 25,000 gal

- NRF-711B-001 Boiler house fuel storage tank, 25,000 gal

- NRF-711C-001 Boiler house fuel storage tank, 25,000 gal

- NRF-718-001 Fire pump fuel oil tank, $500 \mathrm{gal}$

- NRF-728-008 Fire pump fuel oil tank, $500 \mathrm{gal}$

- NRF-745-001 Sulfuric acid tank, 6,800 gal

- NRF-745-002 Sodium hydroxide tank, 6,800 gal

- NRF-PRT-006 Portable propane heater 


\subsection{Power Burst Facility}

\subsubsection{Area Description}

The PBF area is located approximately 6 miles northeast of CFA and is shown in Figure 10. Originally, the PBF was used to test reactor transient behavior and for safety studies on light-watermoderated enriched-fuel systems. These tests were called Special Power Excursion Reactor Test (SPERT) and commenced in the late 1950s. At that time, the PBF area consisted of the Control Area and the Reactor Area, the latter including SPERT I (now decontaminated, dismantled, and returned to its natural state), SPERT II, SPERT III, and SPERT IV reactors. The PBF Control Area served as the control center for all SPERT and PBF operations.

The PBF Control Area (Figure 11) now is the central administrative area for the PBF operations. The buildings at the control area house the PBF reactor controls, offices, maintenance and instrumentation areas.

The PBF Reactor Area (Figure 12) consists of the PBF reactor, which was constructed north of the SPERT I reactor site. The SPERT I reactor was decommissioned in 1964 and the area has been revegetated. The PBF reactor has been used for reactor research on fuel behavior during normal and offnormal operating conditions but has been shut down pending inactivation.

The SPERT II area (Figure 13) consists mainly of the SPERT II reactor, which was constructed to study kinetic behavior for information on reactor safety. The reactor has been decommissioned, and most of the equipment (i.e., reactor vessel and primary coolant loop) has been removed. The building now houses the Waste Engineering Development Facility (WEDF), which is used for clean lead receiving, storing, and shipping and for office space.

The SPERT III area (Figure 14) consisted of SPERT III Reactor Building (PER-609), built in the late 1950s. The reactor was designed for studies on high-power, high-temperature, heterogeneous, light water reactors. Its primary function was to determine the effect of water flow, pressure, and temperature on the transient characteristics of the reactor. The reactor was placed in standby in 1968 and was decontaminated and decommissioned in 1980. All system components were removed and the remaining areas were decontaminated. The area was converted to the Waste Experimental Reduction Facility (WERF). Facilities at WERF include a 4.8-million Btu/hr incinerator, a 200-ton compactor, and a 960-ft 2 sizing shop where metallic waste is cut up using plasma arc torches, alternate repackaging area in Room B102 for mixed waste prior to incineration, and an interim status storage facility for mixed waste. Future plans at WERF include an mixed waste sizing and a macroencapsulation unit at PER-622.. Also included are an offgas/ash solidification room, indoor mixed waste storage, and a 4,600- $\mathrm{ft}^{2}$ outdoor radioactive waste storage area. The compactor is used to process all materials that cannot be processed through the incinerator (such as PVC). The solidification process is used to stabilize the incinerator ash by solidifying the ash with cement/water. 


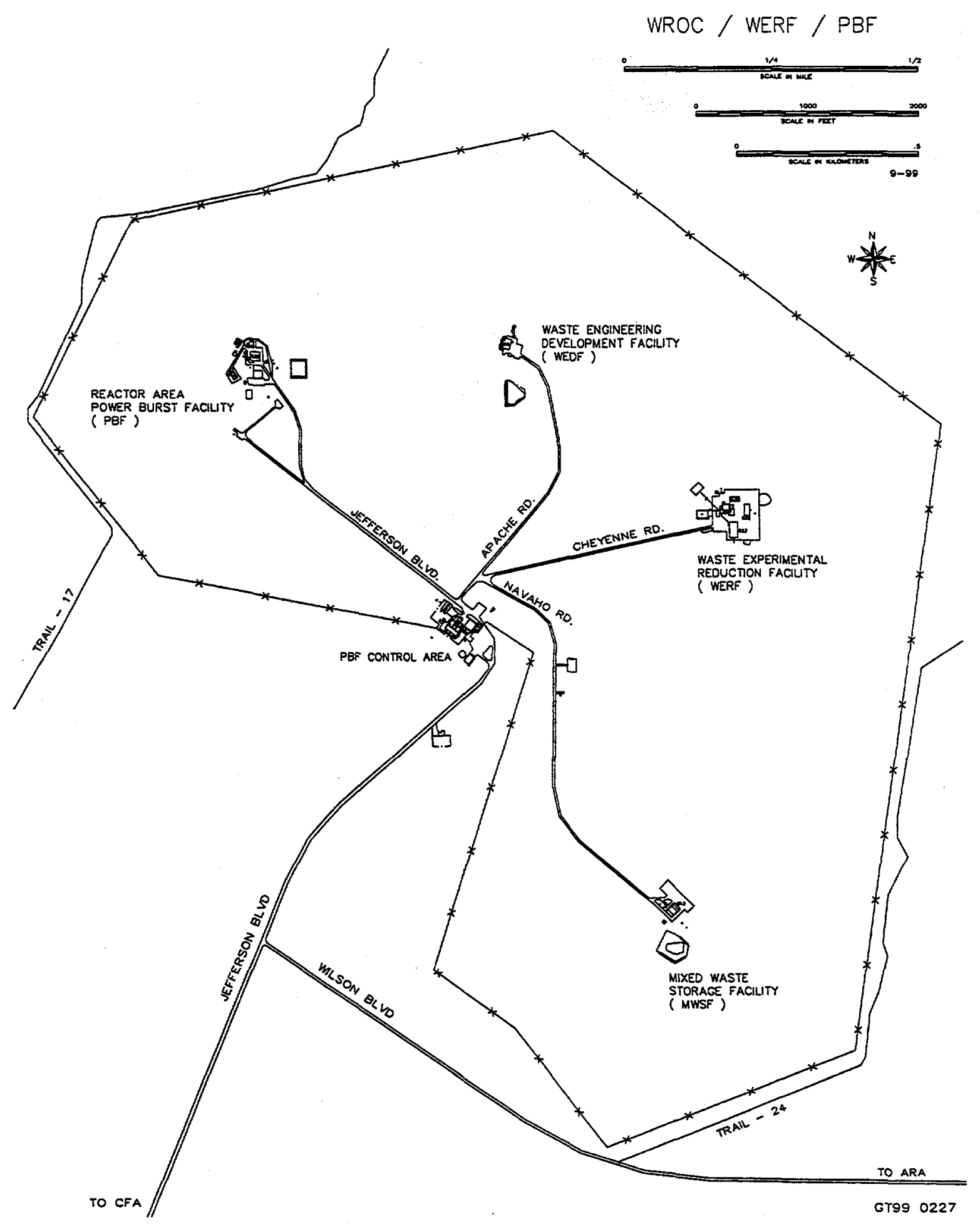

Figure 10. Area plot plan of the Power Burst Facility. 


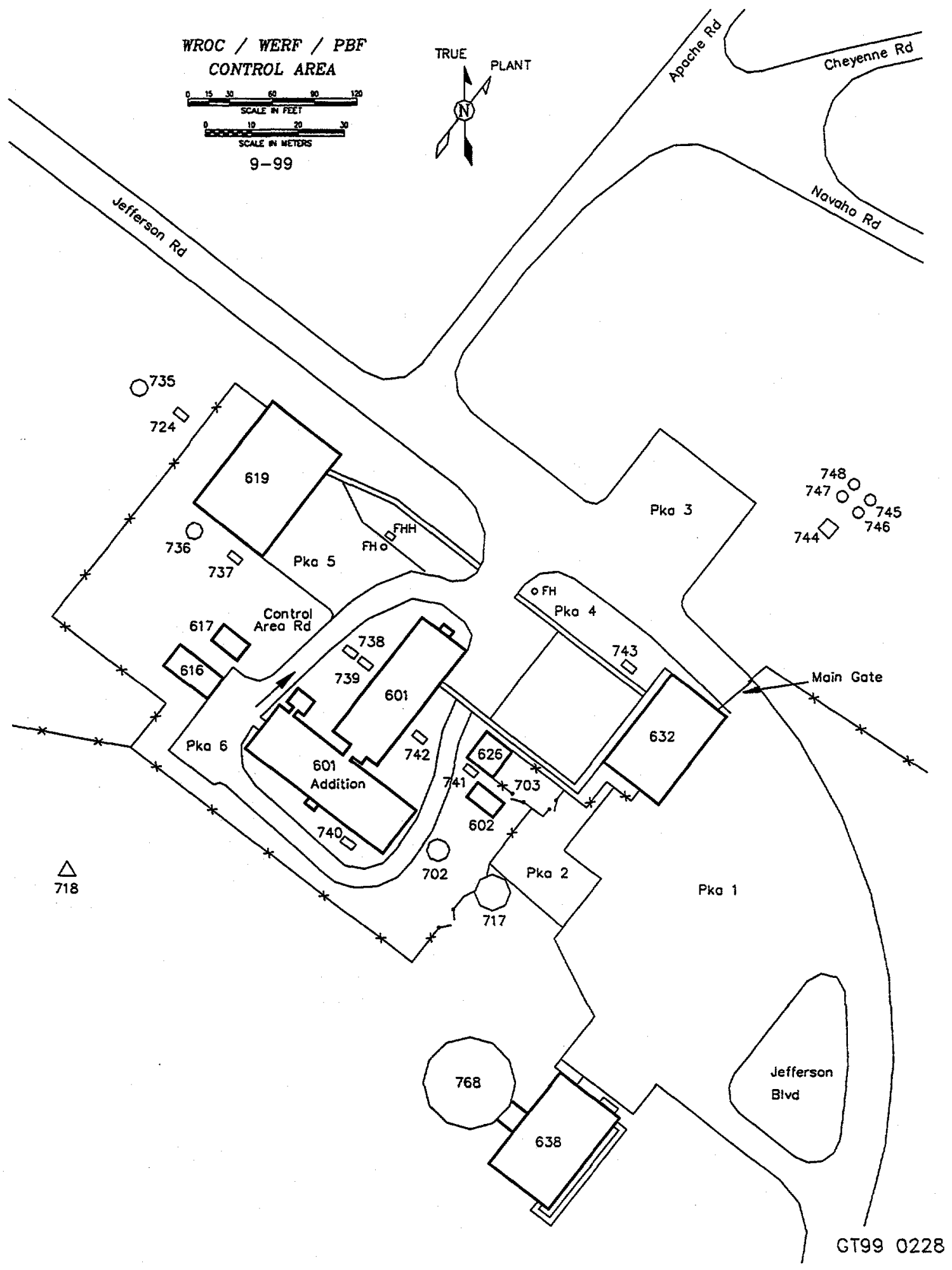

Figure 11. Area plot plan of PBF control area. 


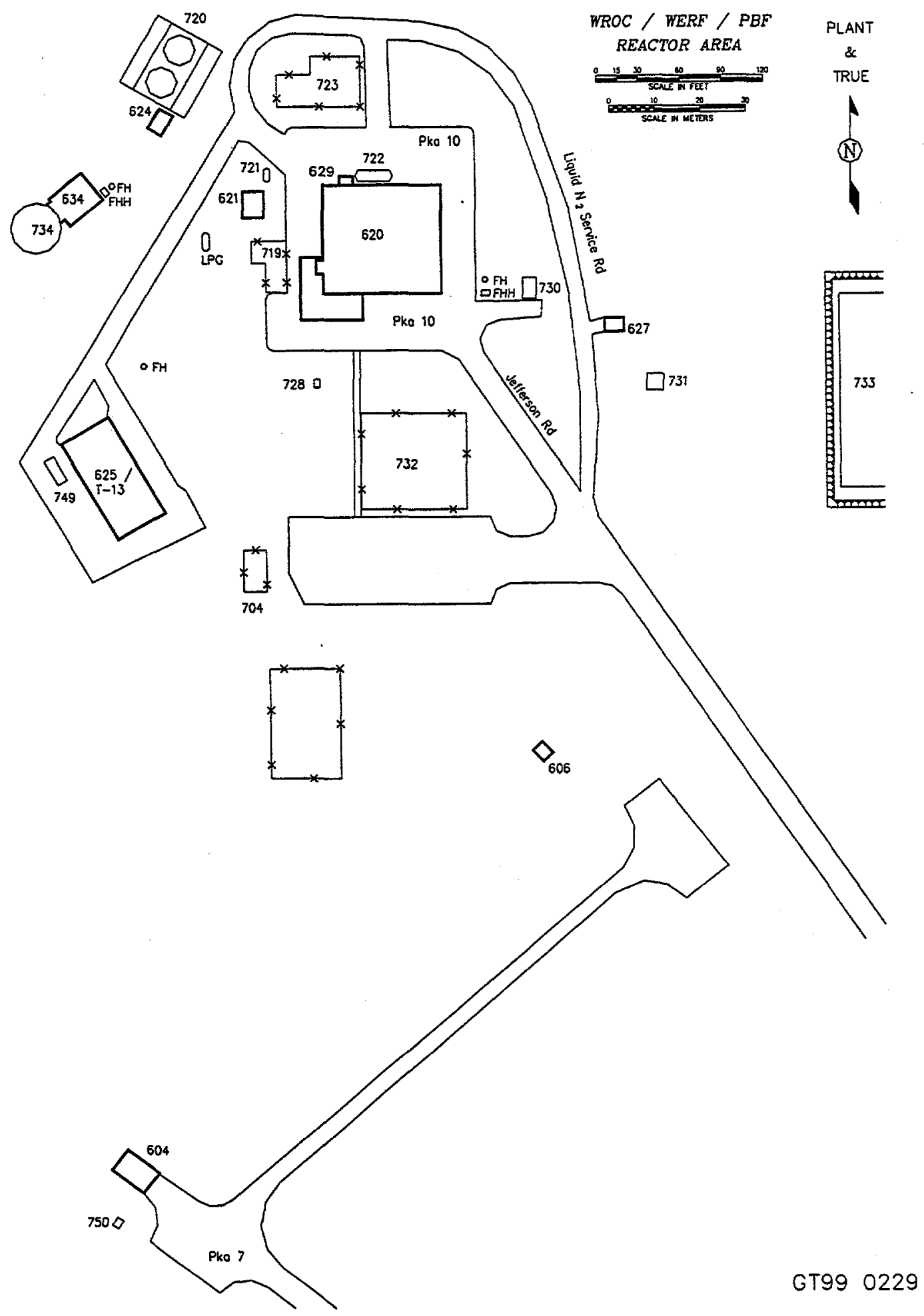

Figure 12. Area plot plan of PBF reactor area. 

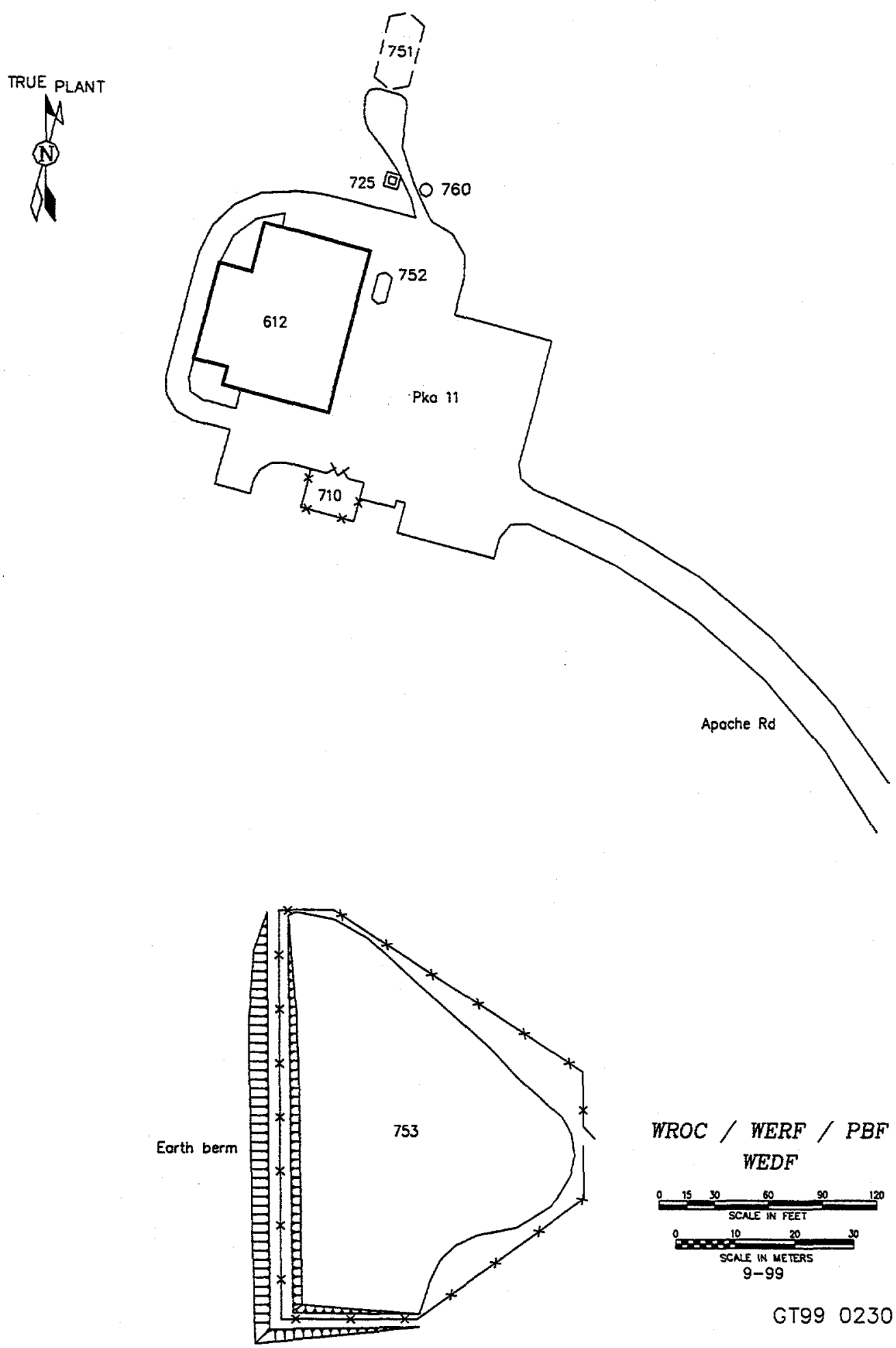

Figure 13. Area plot plan of WEDF. 


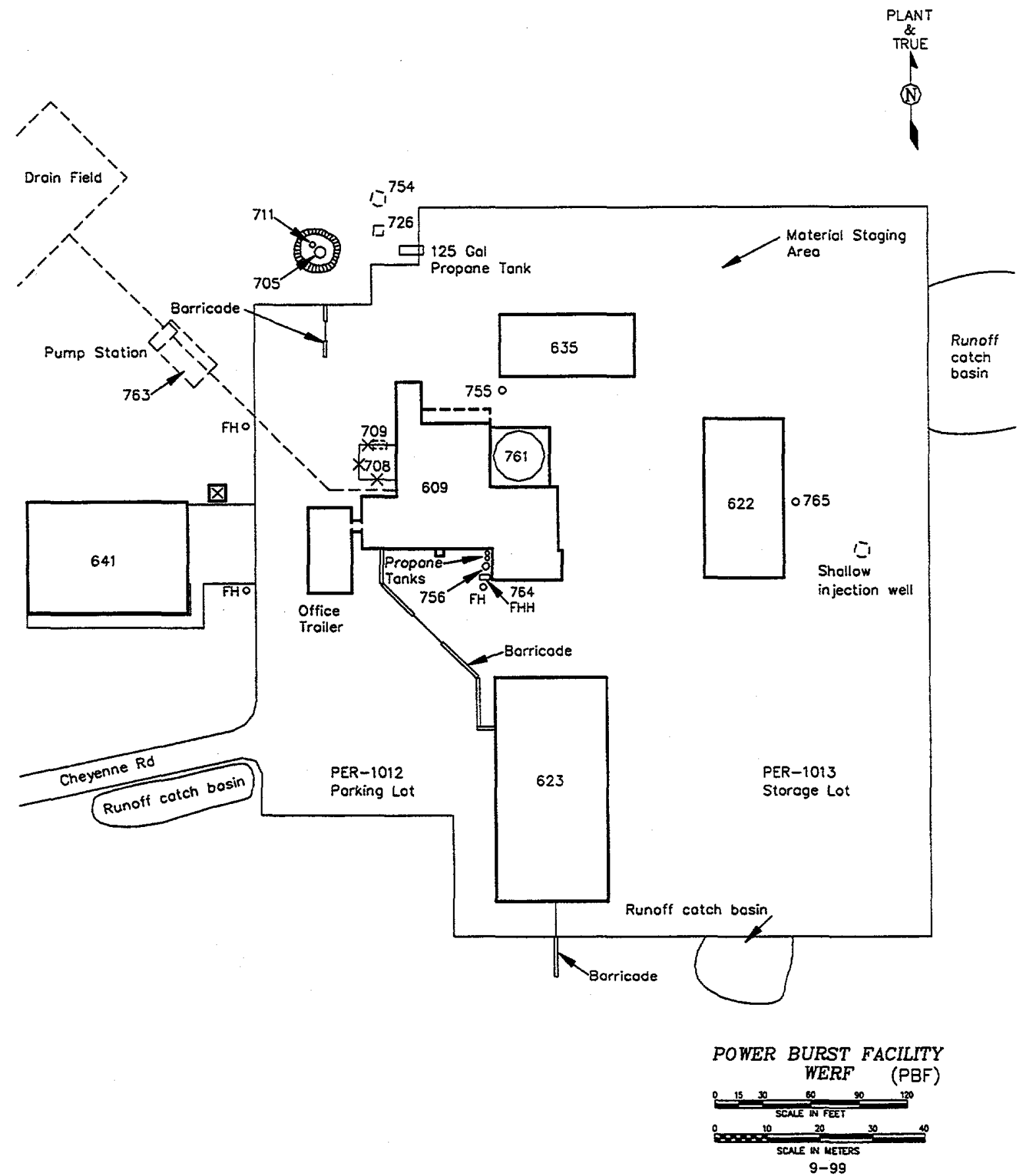

GT99 0231

Figure 14. Area plot plan of WERF. 


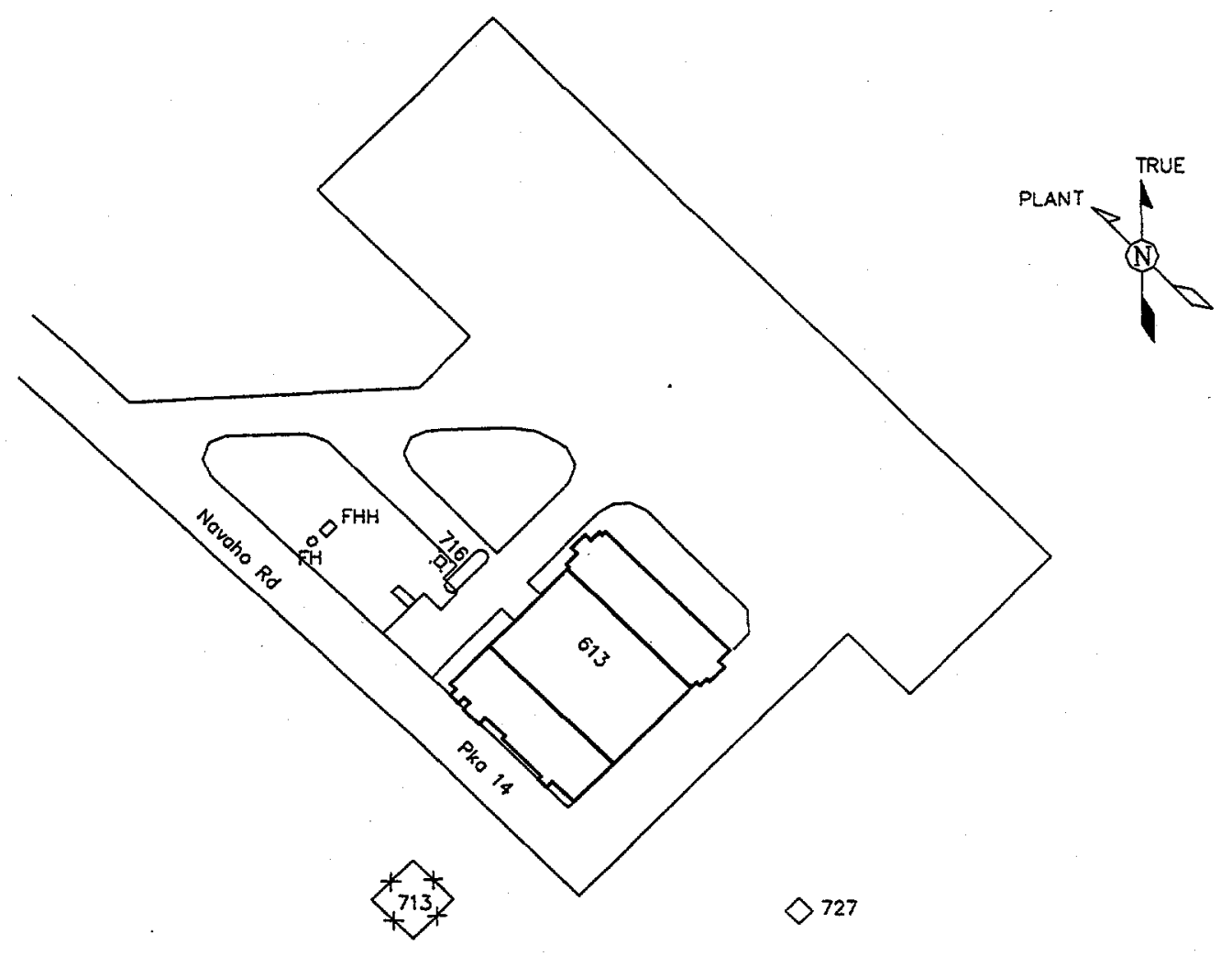

O 757

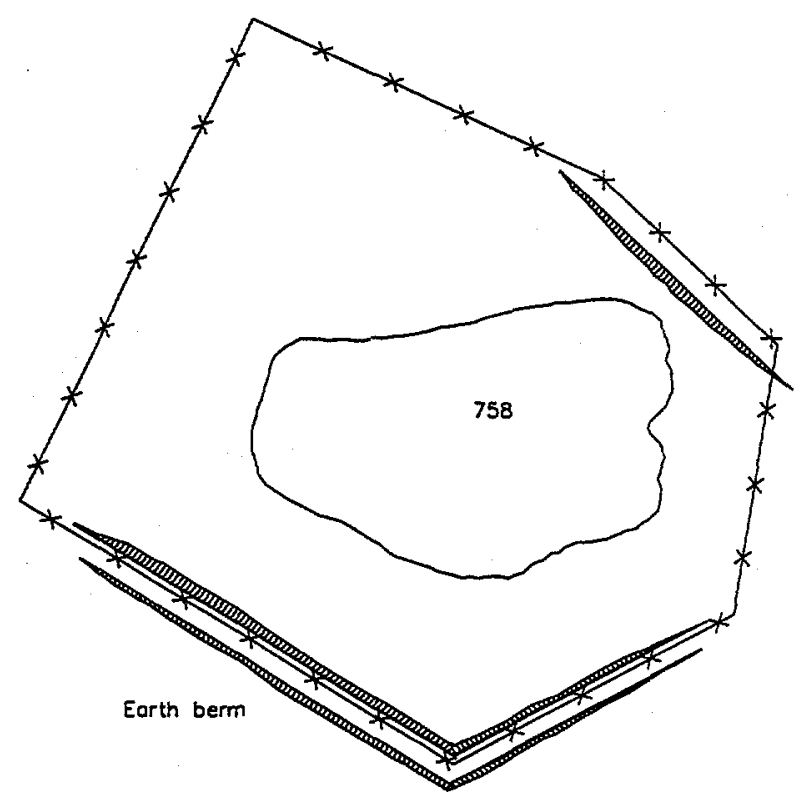

WROC / WERF / PBF MWSF

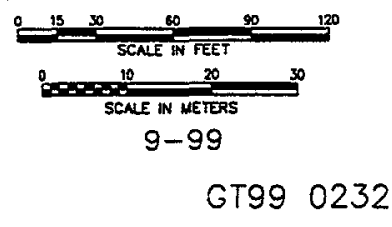

Figure 15. Area plot plan of MWSF. 
The SPERT IV reactor (Figure 15) was constructed to extend the range and type of controlled test parameters and to provide a facility for the kinetic testing of advanced-design reactor cores. The reactor has been removed, and the area is being used to store mixed waste and has been renamed as the Mixed Waste Storage Facility (MWSF). MWSF is now a Resource Conservation and Recovery Act (RCRA) Storage Facility under RCRA interim status for the storage of mixed waste, which is both hazardous [defined by Code of Federal Regulations (CFR) 40 CFR 261] and radioactive. MWSF has segregated areas to accommodate storage of polychlorinated biphenyls (PCBs), corrosives, and flammables in compliance with RCRA requirements. Special provisions for these waste forms include special isolation diking and ventilation systems. A repackaging booth inside the MWSF is used to transfer liquid waste to incinerable absorbent material (e.g. ground corn cobs) and segregate solid waste material into burn boxes to meet desired feed characteristics for the boxes for treatment in the WERF incinerator.

\subsubsection{Significant Source Descriptions}

The significant sources at the PBF are one boilers used for heating in the winter, two internal combustion engines and the WERF incinerator. The internal combustion engines include a $200 \mathrm{hp}$ diesel fire water pump and a $335 \mathrm{hp}$ generator for standby power. These two sources are included in a group source.

The boiler is located in PER-620. Two boilers have been identified in the ICPP Nitrogen Oxide Sources permit as CFA/PER-613 B-501 (Powermaster boiler) and CFA/PEF-620 M-31 (Cyclotherm boiler), but PER-613 has been removed from service and is inactive. The boilers is designed to run automatically from September to May of each year and have essentially the same allowable emission level in the permit.

WERF is dedicated to volume reduction processes for low-level radioactive and mixed waste.

WERF consists of PER-609, PER-622, PER-623, and a storage area located northwest of PER-622. Three processes take place in PER-609: a) incineration of combustible solid and liquid low-level radioactive and mixed waste, b) solidification, by grouting, of mixed waste and c) repackaging in Room B102 as an alternate location from PER-613 repackaging booth. PER-622 houses sizing, compaction, and wastesorting operations. Sizing reduces the volume of low-level radioactively contaminated metal for further processing or more efficient disposal at the RWMC. Future plans also include sizing of mixed waste and macroencapsulation of hazardous debris waste. PER-623, the WERF Waste Storage Building (WWSB), provides interim storage of hazardous and mixed waste until the waste is treated at an INEEL treatment unit or is shipped offsite for treatment and/or disposal. Compaction reduces the volume of materials that cannot be incinerated or exceed contamination limits for incineration. An open air asphalt and concrete pad is used to store low-level beta-gamma contaminated waste destined for processing. The waste can be in the form of actual structures or assemblies with the contaminated portions covered, or cargo containers containing incinerable waste. 


\subsubsection{Not significant Sources}

The majority of the PBF area not significant sources are fuel burning equipment and VOC storage tanks. There are also two inorganic storage tanks (sulfuric acid). The VOC storage tanks contain No. 2 diesel or gasoline.

Table 15. Not significant sources at the Power Burst Facility areas.

\begin{tabular}{|c|c|c|c|c|}
\hline $\begin{array}{l}\text { Building } \\
\text { number }\end{array}$ & $\begin{array}{l}\text { Building } \\
\text { name }\end{array}$ & $\begin{array}{l}\text { Vent- } \\
\text { stack number }\end{array}$ & Source description & Justification \\
\hline \multirow[t]{2}{*}{ PER-601 } & $\begin{array}{l}\text { WROC Admin } \\
\text { Building }\end{array}$ & PER-601-010 & Heater & $<1 \mathrm{MBtu} / \mathrm{hr}$ input \\
\hline & & PER-601A-010 & Heater & $<1 \mathrm{MBtu} / \mathrm{hr}$ input \\
\hline PER-705 & WERF Fuel Tank & PER-705-001 & 4,000 gal fuel tank & $<10,000 \mathrm{gal}$ \\
\hline PER-711 & Diesel Fuel Tank & PER-711-001 & 350 gal fuel tank & $<10,000 \mathrm{gal}$ \\
\hline PER-612 & $\begin{array}{l}\text { Waste } \\
\text { Engineering } \\
\text { Development } \\
\text { Facility }\end{array}$ & PER-612-006 & Heater & $<1 \mathrm{MBtu} / \mathrm{hr}$ input \\
\hline \multirow[t]{2}{*}{ PER-619 } & $\begin{array}{l}\text { PBF Reactor } \\
\text { Control Building }\end{array}$ & PER-619-015 & Heater & $<1 \mathrm{MBtu} / \mathrm{hr}$ input \\
\hline & & PER-619-016 & Heater & $<1 \mathrm{MBtu} / \mathrm{hr}$ input \\
\hline PER-779 & $\begin{array}{l}\text { PBF Reactor } \\
\text { Control Building }\end{array}$ & PER-779-001 & 2,700 gal fuel tank & $<10,000 \mathrm{gal}$ \\
\hline PER-620 & $\begin{array}{l}\text { PBF Reactor } \\
\text { Building }\end{array}$ & PER-620-001 & $\begin{array}{l}\text { Sulfuric acid storage } \\
\text { tank }\end{array}$ & Inorganics \\
\hline PER-722 & $\begin{array}{l}\text { PBF Reactor } \\
\text { Building }\end{array}$ & PER-722-001 & 10,000 gal fuel tank & $<10,000 \mathrm{gal}$ \\
\hline PER-620 & $\begin{array}{l}\text { PBF Reactor } \\
\text { Building }\end{array}$ & PER-620-016 & Reactor Main Stack & $\begin{array}{l}\text { insignificant for } \\
\text { nonrad emissions }\end{array}$ \\
\hline PER-706 & $\begin{array}{l}\text { PBF Reactor } \\
\text { Building }\end{array}$ & PER-706-001 & PBF Evaporator tank & $\begin{array}{l}\text { insignificant for } \\
\text { nonrad emissions }\end{array}$ \\
\hline \multirow[t]{2}{*}{ PER-621 } & $\begin{array}{l}\text { Standby } \\
\text { Generator } \\
\text { Building }\end{array}$ & PER-621-001 & $\begin{array}{l}\text { Propane standby } \\
\text { generator }\end{array}$ & $<100 \mathrm{hp}$ \\
\hline & & PER-621-002 & 250 gal propane tank & $<40,000 \mathrm{gal}$ \\
\hline
\end{tabular}


Table 15. Not significant sources at the Power Burst Facility areas.

\begin{tabular}{|c|c|c|c|c|}
\hline $\begin{array}{l}\text { Building } \\
\text { number }\end{array}$ & $\begin{array}{l}\text { Building } \\
\text { name }\end{array}$ & $\begin{array}{l}\text { Vent- } \\
\text { stack number }\end{array}$ & Source description & Justification \\
\hline$\overline{\text { PER-624 }}$ & $\begin{array}{l}\text { PBF Cooling } \\
\text { Tower }\end{array}$ & PER-624-005 & $\begin{array}{l}\text { Sulfuric acid storage } \\
\text { container }\end{array}$ & Inorganics \\
\hline \multirow[t]{2}{*}{ PER-625 } & $\begin{array}{l}\text { Maintenance and } \\
\text { Storage Building }\end{array}$ & PER-625-002 & $\begin{array}{l}24 \text { gal fuel tank } \\
\text { Inactive }\end{array}$ & $<10,000 \mathrm{gal}$ \\
\hline & & PER-625-004 & $\begin{array}{l}15 \text { gal fuel tank } \\
\text { Inactive }\end{array}$ & $<10,000 \mathrm{gal}$ \\
\hline \multirow[t]{2}{*}{ PER-632 } & PBF Gatehouse & PER-632-007 & Heater & $\begin{array}{l}<50 \mathrm{MBtu} / \mathrm{hr} \\
\text { input }\end{array}$ \\
\hline & & PER-632-008 & Heater & $\begin{array}{l}<50 \mathrm{MBtu} / \mathrm{hr} \\
\text { input }\end{array}$ \\
\hline PER-638 & $\begin{array}{l}\text { Fire Water Pump } \\
\text { house }\end{array}$ & PER-638-004 & $\begin{array}{l}200 \mathrm{hp} \mathrm{fire} \mathrm{water} \\
\text { pump }\end{array}$ & $<450 \mathrm{hr} /$ month \\
\hline PER-771 & $\begin{array}{l}\text { PER } 601 \text { Building } \\
\text { Heater Fuel Tank }\end{array}$ & PER-771-001 & 2,500 gal fuel tank & $<10,000 \mathrm{gal}$ \\
\hline PER-772 & $\begin{array}{l}\text { PER } 601 \text { Building } \\
\text { Heater Fuel Tank }\end{array}$ & PER-772-001 & 1,000 gal fuel tank & $<10,000 \mathrm{gal}$ \\
\hline PER-773 & $\begin{array}{l}\text { Gatehouse Heater } \\
\text { Fuel Tank }\end{array}$ & PER-773-001 & 2,500 gal fuel tank & $<10,000 \mathrm{gal}$ \\
\hline PER-774 & $\begin{array}{l}\text { PER } 612 \text { Building } \\
\text { Heater Fuel Tank }\end{array}$ & PER-774-001 & 2,500 gal fuel tank & $<10,000 \mathrm{gal}$ \\
\hline PER-778 & MWSF & PER-778-001 & $4,000 \mathrm{gal}$ fuel tank & $<10,000 \mathrm{gal}$ \\
\hline
\end{tabular}

\subsubsection{Summary of PBF Emissions}

Totals of each of the nonradionuclide principal pollutant emissions from sources at PBF during 1998 are summarized in Table 16. 
Table 16. Summary of nonradionuclide principal pollutants at PBF.

\begin{tabular}{lcc} 
Pollutant & \multicolumn{2}{c}{ Emissions } \\
Hourly & lb/hr & $\begin{array}{c}\text { Annual } \\
\text { ton/yr }\end{array}$ \\
\hline Carbon monoxide & $1.3 \mathrm{E}-01$ & $1.1 \mathrm{E}-01$ \\
Nitrogen oxides & $1.4 \mathrm{E}+00$ & $1.9 \mathrm{E}+00$ \\
PM-10 & $4.4 \mathrm{E}-02$ & $6.4 \mathrm{E}-02$ \\
Sulfur oxides & $3.3 \mathrm{E}+00$ & $2.8 \mathrm{E}+00$ \\
VOC - nonmethane & $6.0 \mathrm{E}-03$ & $2.6 \mathrm{E}-02$
\end{tabular}

\subsubsection{Summary of PBF Changes}

Changes to emission sources from the 1997 AEI include the removal from service of PER-613 boiler, designation change of sources PER-638-004 and PER-609-006 and source heaters.

\subsubsection{Hydrochloric Acid Emissions}

Hydrochloric acid emissions form the WERF stack (PER 755) were estimated at 3,900 pounds for 1998. The emissions result from the incineration of chlorinated materials (primarily PVC). The estimate was based on RCRA trial burn results using the maximum allowable ( $400 \mathrm{lb} / \mathrm{hr})$ PVC feed rate. The measured $\mathrm{HCl}$ emission rate was $1.52 \mathrm{lb} / \mathrm{hr}$. The WERF ran for 2,592 $\mathrm{hr}$ during 1998 . Total emissions were based on $1.52 \mathrm{lb} / \mathrm{hr} \times 2,592 \mathrm{hr}$. Actual emissions were probably lower than the estimate because the PVC feed rate is generally below the maximum allowable. 


\subsection{Radioactive Waste Management Complex}

\subsubsection{Area Description}

RWMC was established in 1952 and is located 7 miles southwest of CFA. RWMC, a restricted area, provides waste management for solid low-level radioactive and transuranic wastes. Waste management includes retrieval, examination, and certification of transuranic waste for ultimate disposal at the DOE Waste Isolation Pilot Plant in New Mexico. The facility also supports research and development activities for shallow land burial technology. Figure 16 presents a plot plan of RWMC.

The RWMC comprises four major areas: the Administrative Area, the Operations Area, the Subsurface Disposal Area (SDA), and the Transuranic Storage Area (TSA).

The Administrative Area is located in the northeast section of the RWMC and consists of buildings and structures supporting RWMC administrative operations. These include office space and change rooms (for RWMC workers) and the security gate.

The Operations Area is located in the northeast section of the RWMC adjacent to the Administrative Area and consists of buildings and structures supporting RWMC operations. These include office space, the fire and domestic water supply and equipment storage and maintenance areas.

The SDA is a fenced, 97 acre, shallow-land subsurface disposal site located in the western section of the RWMC. It is dedicated to the permanent disposal of solid, low-level beta-gamma waste. The SDA contains pits, trenches, soil vaults, and an asphalt pad ( $\mathrm{Pad} \mathrm{A})$. TRU waste disposal was discontinued in 1970. Pad A ceased operation in 1978. Only low-level waste which is not "hazardous" per RCRA, has continued to be disposed of in the SDA in pits and vaults. A CERCLA waste retrieval and processing demonstration project is currently being constructed in the Pit 9 area of the SDA.

The TSA is a fenced, 56 acre storage area located in the southeastern section of the RWMC. The TSA stores TRU radioactive (only), TRU mixed, low-level radioactive (only), and low-level mixed waste. The major functions of the TSA are storage, examination and certification of contact-handled $(\mathrm{CH})$ and remote-handled (RH) solid TRU waste which is destined for shipment to the Waste Isolation Pilot Plant (WIPP) or for treatment at an on- or off-site facility.

\subsubsection{Significant Source Descriptions}

There are six sources of air emissions at the RWMC currently listed as having significant air emissions. Three of these sources are radioactive emission sources and are not listed in this report. The three nonradioactive sources are; 1. a standby generator (WMF 734) 2. a propane heater (WMF 636) that are permitted in the TSA Retrieval Enclosure and Waste Storage Facility PTC 3. the Waste Storage Facility modules.

\subsubsection{Not Significant Sources}

Not significant sources of air emissions at the RWMC are shown in Table 17. 
Table 17. Not significant sources at RWMC.

\begin{tabular}{|c|c|c|c|c|}
\hline $\begin{array}{l}\text { Building } \\
\text { number }\end{array}$ & Building name & Vent/stack number & Source description & Justification \\
\hline WMF-601 & $\begin{array}{l}\text { Radiological } \\
\text { Control } \\
\text { Technician } \\
\text { Building }\end{array}$ & WMF-601-009 & $\begin{array}{l}\text { Nonradionuclide } \\
\text { emissions from } \\
\text { laboratory hood }\end{array}$ & $\begin{array}{l}\text { Analytical } \\
\text { laboratory, }<5 \% \\
\text { of significant } \\
\text { emissions and }<2 \\
\text { ton/yr of any } \\
\text { HAP. }\end{array}$ \\
\hline WMF-603 & Pump house & WMF-603-005 & $\begin{array}{l}235 \mathrm{hp} \text { propane } \\
\text { standby generator }\end{array}$ & $<1 \mathrm{MBtu} / \mathrm{hr}$ \\
\hline \multirow[t]{3}{*}{ WMF-610 } & $\begin{array}{l}\text { Solid Waste } \\
\text { Experimental } \\
\text { Pilot Plant }\end{array}$ & WMF-610-003 & $\begin{array}{l}100 \mathrm{hp} \text { propane } \\
\text { standby generator }\end{array}$ & $<1 \mathrm{MBtu} / \mathrm{hr}$ \\
\hline & & WMF-610-004 & $\begin{array}{l}\text { two } 400,000 \mathrm{Btu} / \mathrm{hr} \\
\text { propane furnaces }\end{array}$ & $\begin{array}{l}\text { Propane } \\
\text { equipment }\end{array}$ \\
\hline & & & & $<5 \mathrm{MBtu} / \mathrm{hr}$ \\
\hline WMF-612 & $\begin{array}{l}\text { SWEPP C\&S } \\
\text { Storage Building }\end{array}$ & WMF-612-001 & $\begin{array}{l}40 \mathrm{hp} \text { propane } \\
\text { standby generator }\end{array}$ & $<1 \mathrm{MBtu} / \mathrm{hr}$ \\
\hline WMF-615 & $\begin{array}{l}\text { Drum Venting } \\
\text { Facility }\end{array}$ & WMF-615-001 & $\begin{array}{l}\text { VOC emissions } \\
\text { from drum } \\
\text { headspace }\end{array}$ & $\begin{array}{l}\text { Directors } \\
\text { exemption }\end{array}$ \\
\hline WMF-635 & $\begin{array}{l}\text { Sampling and } \\
\text { Characterization } \\
\text { tent }\end{array}$ & $\begin{array}{l}\text { WMF-635-000 } \\
\text { (formerly 602-001) }\end{array}$ & $\begin{array}{l}\text { Sampling and } \\
\text { characterization tent }\end{array}$ & $\begin{array}{l}\text { Directors } \\
\text { exemption }\end{array}$ \\
\hline WMF-635 & $\begin{array}{l}\text { Type } 1 \text { Storage } \\
\text { Module }\end{array}$ & WMF-635-002 & $\begin{array}{l}\text { VOCvapors from } \\
\text { heated waste }\end{array}$ & $\begin{array}{l}\text { Categorical } \\
\text { exemption }\end{array}$ \\
\hline \multirow[t]{2}{*}{ WMF-637 } & $\begin{array}{l}\text { Operations } \\
\text { Control Building }\end{array}$ & WMF-637-001 & $\begin{array}{l}\text { Two } 1.2 \mathrm{MBtu} / \mathrm{hr} \\
\text { propane fueled } \\
\text { boilers }\end{array}$ & $\begin{array}{l}\text { Propane } \\
\text { equipment } \\
<5 \mathrm{MBtu} / \mathrm{hr}\end{array}$ \\
\hline & & WMF-637-002 & $\begin{array}{l}1.2 \mathrm{MBtu} / \mathrm{hr} \\
\text { propane water } \\
\text { heater }\end{array}$ & $\begin{array}{l}\text { Propane } \\
\text { equipment } \\
<5 \mathrm{MBtu} / \mathrm{hr}\end{array}$ \\
\hline
\end{tabular}


Table 17. Not significant sources at RWMC.

\begin{tabular}{|c|c|c|c|c|}
\hline $\begin{array}{l}\text { Building } \\
\text { number }\end{array}$ & Building name & Vent/stack number & Source description & Justification \\
\hline \multirow[t]{2}{*}{ WMF-639 } & $\begin{array}{l}\text { RWMC Pump } \\
\text { house }\end{array}$ & WMF-639-001 & $\begin{array}{l}217 \text { hp standby } \\
\text { diesel firewater } \\
\text { pump }\end{array}$ & $<1 \mathrm{MBtu} / \mathrm{hr}$ \\
\hline & & WMF-639-001 & $\begin{array}{l}250 \text { gal diesel } \\
\text { storage tank }\end{array}$ & $\begin{array}{l}<10,000 \text { gal } \\
\text { diesel tank }\end{array}$ \\
\hline WMF-656 & Wood shop & WMF-656-002 & sawdust & $\begin{array}{l}\text { Emits }<0.7 \\
\text { tons/yr particulate }\end{array}$ \\
\hline WMF-703 & $\begin{array}{l}\text { Propane Tank } \\
\text { and fill Station }\end{array}$ & WMF-703-001 & $\begin{array}{l}30,000 \text { gal propane } \\
\text { tank }\end{array}$ & $\begin{array}{l}<40,000 \mathrm{gal} \\
\text { propane tank }\end{array}$ \\
\hline WMF-711 & $\begin{array}{l}\text { Air Support } \\
\text { Weather Shield }\end{array}$ & WMF-711-001 & $\begin{array}{l}4 \mathrm{MBtu} / \mathrm{hr} \text { propane } \\
\text { furnace }\end{array}$ & $\begin{array}{l}\text { Propane } \\
\text { equipment }<5 \\
\text { MBtu/hr }\end{array}$ \\
\hline WMF-711 & $\begin{array}{l}\text { Air Support } \\
\text { Weather Shield }\end{array}$ & WMF-711-004 & $\begin{array}{l}14 \mathrm{hp} \text { propane fan } \\
\text { engine }\end{array}$ & $<1 \mathrm{MBtu} / \mathrm{hr}$ \\
\hline WMF-732 & Propane Tank & WMF-732-001 & 12,000 propane tank & $\begin{array}{l}<40,000 \text { gal } \\
\text { propane tank }\end{array}$ \\
\hline WMF-735 & Diesel Tank & WMF-735-001 & 1000 gal diesel tank & $\begin{array}{l}<10,000 \text { gal } \\
\text { diesel tank }\end{array}$ \\
\hline WMF-737 & Gasoline Tank & WMF-737-001 & $\begin{array}{l}500 \text { gal gasoline } \\
\text { tank }\end{array}$ & $\begin{array}{l}<10,000 \mathrm{gal} \\
\text { gasoline tank }\end{array}$ \\
\hline WMF-738 & Propane Tank & WMF-738-001 & $\begin{array}{l}500 \text { gal propane } \\
\text { tank }\end{array}$ & $\begin{array}{l}<40,000 \mathrm{gal} \\
\text { propane tank }\end{array}$ \\
\hline
\end{tabular}




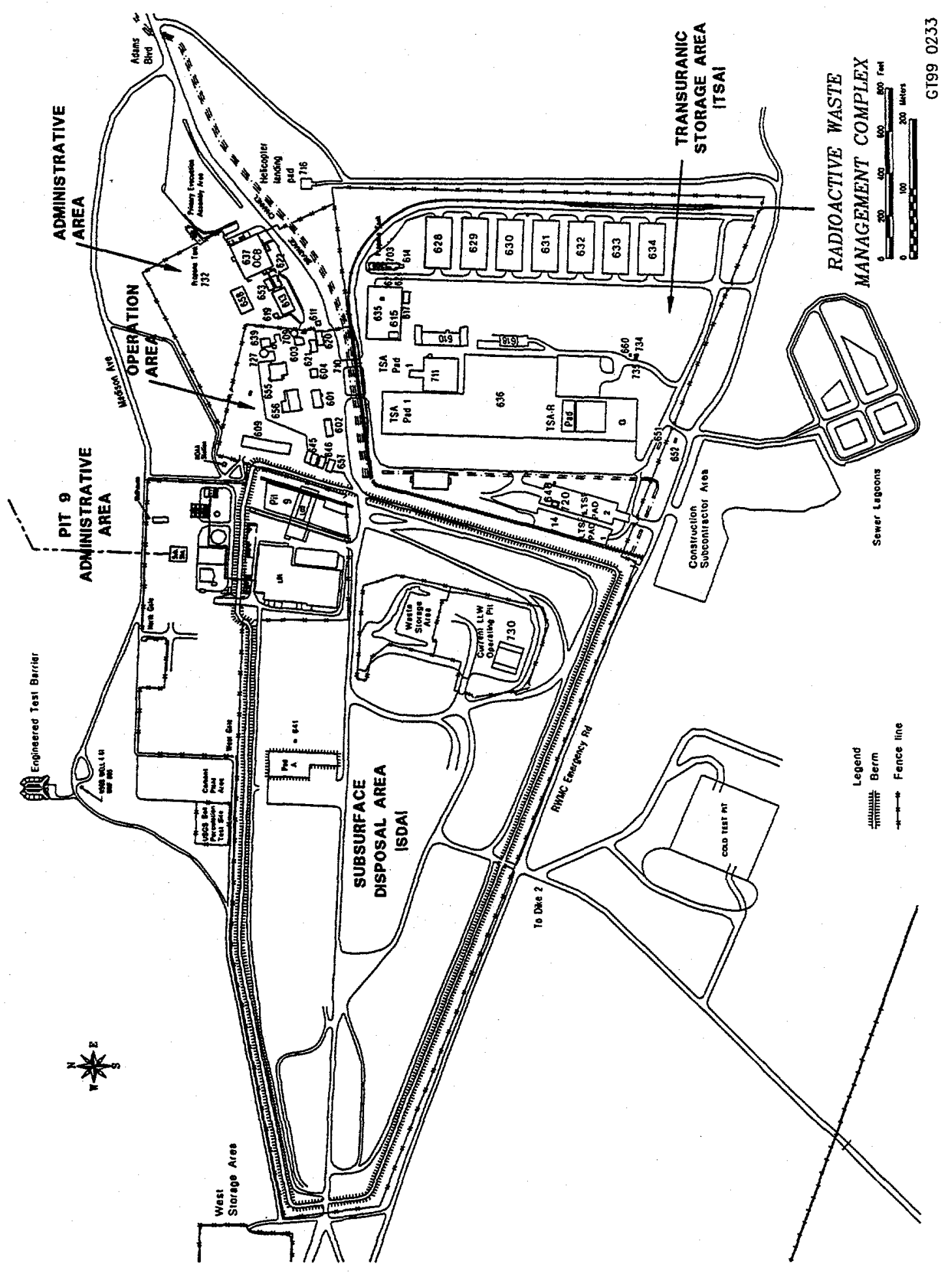

Figure 16. Area plot plan of the Radioactive Waste Management Complex. 


\subsubsection{Summary of RWMC Emissions}

Totals of each of the nonradionuclide principal pollutant emissions from sources at RWMC during 1998 are summarized in Table 18.

Table 18. Summary of nonradionuclide principal pollutants at RWMC.

\begin{tabular}{|c|c|c|}
\hline & & \\
\hline Pollutant & $\begin{array}{c}\text { Hourly } \\
\mathrm{lb} / \mathrm{hr}\end{array}$ & $\begin{array}{r}\text { Annual } \\
\text { ton/yr }\end{array}$ \\
\hline Carbon monoxide & $2.0 \mathrm{E}+00$ & $1.0 \mathrm{E}+00$ \\
\hline Nitrogen oxides & $7.7 \mathrm{E}+00$ & $1.5 \mathrm{E}+01$ \\
\hline PM-10 & $4.0 \mathrm{E}-01$ & $1.2 \mathrm{E}+00$ \\
\hline Sulfur oxides & $1.5 \mathrm{E}+00$ & $3.0 E+00$ \\
\hline VOC - nonmethane & $2.1 \mathrm{E}+02$ & $5.4 \mathrm{E}+00$ \\
\hline
\end{tabular}

\subsubsection{Summary of RWMC Changes}

Table 19 summarizes the changes that have occurred in 1998.

Table 19. Summary of source changes at RWMC - 1997 to 1998 inventory.

\begin{tabular}{|c|c|c|}
\hline Emission Source & 1997 to 1998 Changes & Justification \\
\hline WMF-635-000 & $\begin{array}{l}\text { Source number changed from } \\
\text { WMF-602-001 to WMF-635- } \\
000\end{array}$ & $\begin{array}{l}\text { Sampling and characterization } \\
\text { tent: Directors exemption, will } \\
\text { vent to WMF- } 635 \text { room air. } \\
\text { Any reportable emissions will } \\
\text { be included in WMF- } 635 \\
\text { HVAC exhaust }\end{array}$ \\
\hline WMF-612-001 & Source removed & $\begin{array}{l}\text { Removed during D\&D } \\
\text { activities }\end{array}$ \\
\hline WMF-612-004 & Source removed & $\begin{array}{l}7.5 \mathrm{MBtu} / \mathrm{hr} \text { furnace was } \\
\text { removed }\end{array}$ \\
\hline WMF-738-001 & Newly identified source & 500 gal propane tank \\
\hline
\end{tabular}




\subsubsection{Carbon Tetrachloride and Trichloroethane Emissions}

Carbon tetrachloride emissions were estimated to be 5,400 pounds for 1998. Emissions of 1,1,1trichloroethane were 3,900 pounds for 1998 . These emissions are part of the organic vapor emissions from 70,000 drum equivalents of TRU mixed waste stored in containers inside eight buildings at the RWMC (WMF 628 through 635). Many of the containers are vented to allow diffusion of organic vapors and hydrogen. The emission estimates are based on one-time Open-Path Fourier Transform Infrared Spectroscopy sampling results conducted in a single storage building in the summer of 1994 . The emission rate estimated from this sample was projected to the entire waste inventory throughout the year.

\subsection{Test Area North}

\subsubsection{Area Description}

TAN is located in the northern part of the INEEL site and presently comprises three operational areas: the Technical Support Facility (TSF); the Containment Test Facility (CTF); the Loss Of Fluid Test (LOFT) area, which includes the Specific Manufacturing Capability (SMC) Project; and the Water Reactor Research Test Facility (WRRTF).

The TSF area functions as the administrative and support hub for all areas of TAN except the SMC Project. TAN supports many important programs, including Three Mile Island Unit 2 Core Offsite Examination; the Process Experimental Pilot Plant; and the Spent Fuel Program. Maintenance and operations activities for TSF \& WRRTF is split between the Central Facilities Area (CFA) facilities personnel and TSF. Figure 17 is an area plot plan of the TSF area.

The LOFT area is approximately 1.5 miles West of the TSF area. This area includes the LOFT containment vessel and service building, the LOFT reactor control and equipment building, and numerous support facilities. LOFT facilities have essentially been non-operational since the mid 1980's. The SMC Project lies just west of the former LOFT facility and its operations are spread between a large concrete hangar and other associated buildings that were constructed to support their manufacturing processes. Currently SMC provides heating support to the old LOFT facility under their current boiler limits listed under the SMC PTC $\# 0340-0001$. Figure 18 is an area plot plan of LOFT/SMC.

The WRRTF area (see Figure 19) includes the Semiscale Project, the Blowdown Project, and the Two-Phase-Flow Loop Project, all of which are now decommissioned. Very little activity now exists at WRRTF, with the exception of some engineering-scale tests.

\subsubsection{Significant Sources}

The boilers at TAN constitute some of the largest sources of emissions from that area and are present in all three of the functional TAN areas. TAN boilers provide steam for space heating and are located in the following buildings: 
1. TAN-603 (TSF) - Two 20.9 MBtu boilers, one 42.8 MBtu boiler.

2. TAN-630 (LOFT, TAN-716) - one boiler (non-operational).

3. TAN-641 (WRRTF) - Two $6.28 \mathrm{MBtu}$ boilers.

4. TAN-679 (LOFT/SMC) - Two 25 MBtu boilers; one 2 MBtu seasonal boiler.

The TAN boilers burn No. 2 grade fuel oil. Since these boilers mostly provide steam for space heating, they typically do not run during the summer months. 


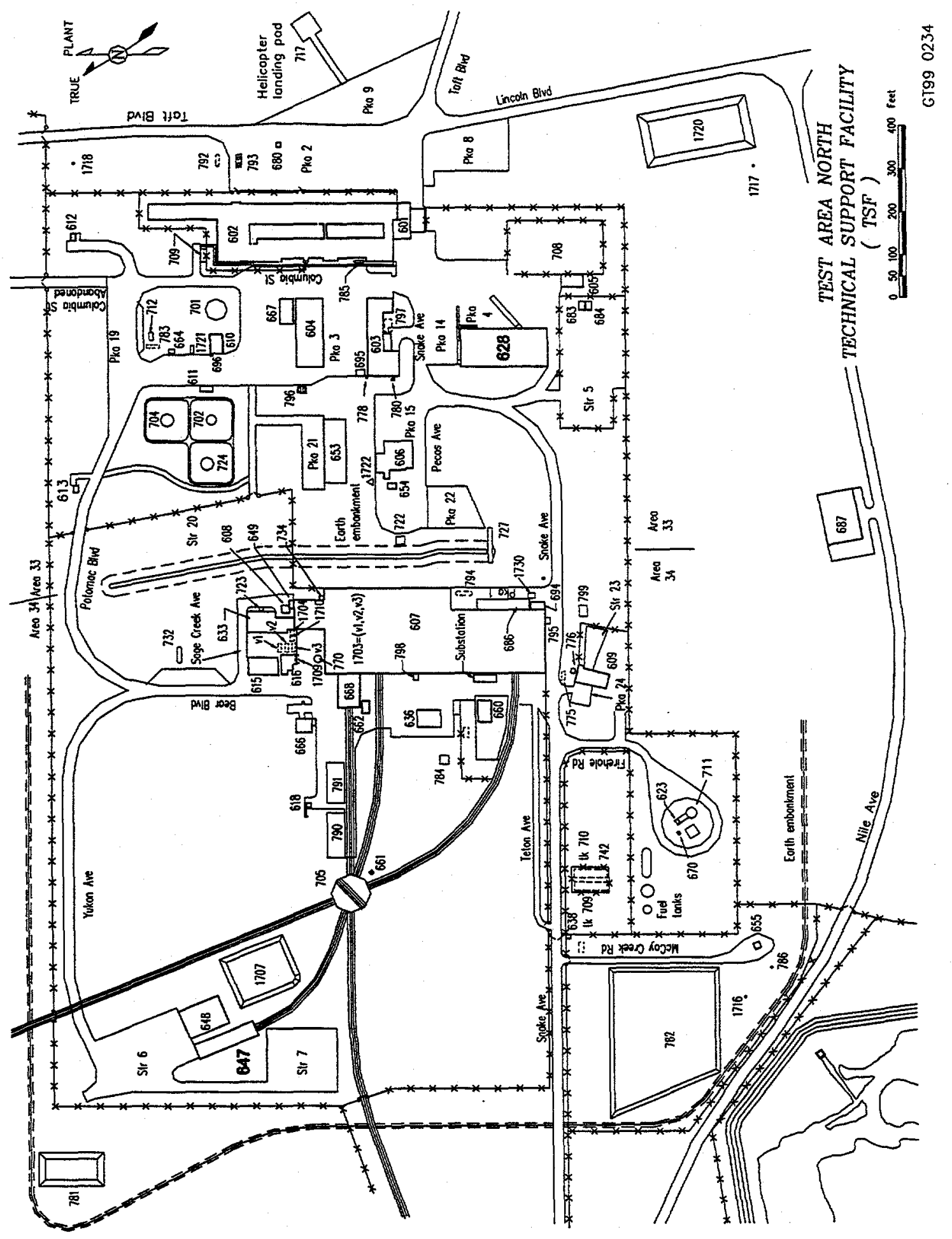

Figure 17. Area plot plan of the Technical Support Facility. 


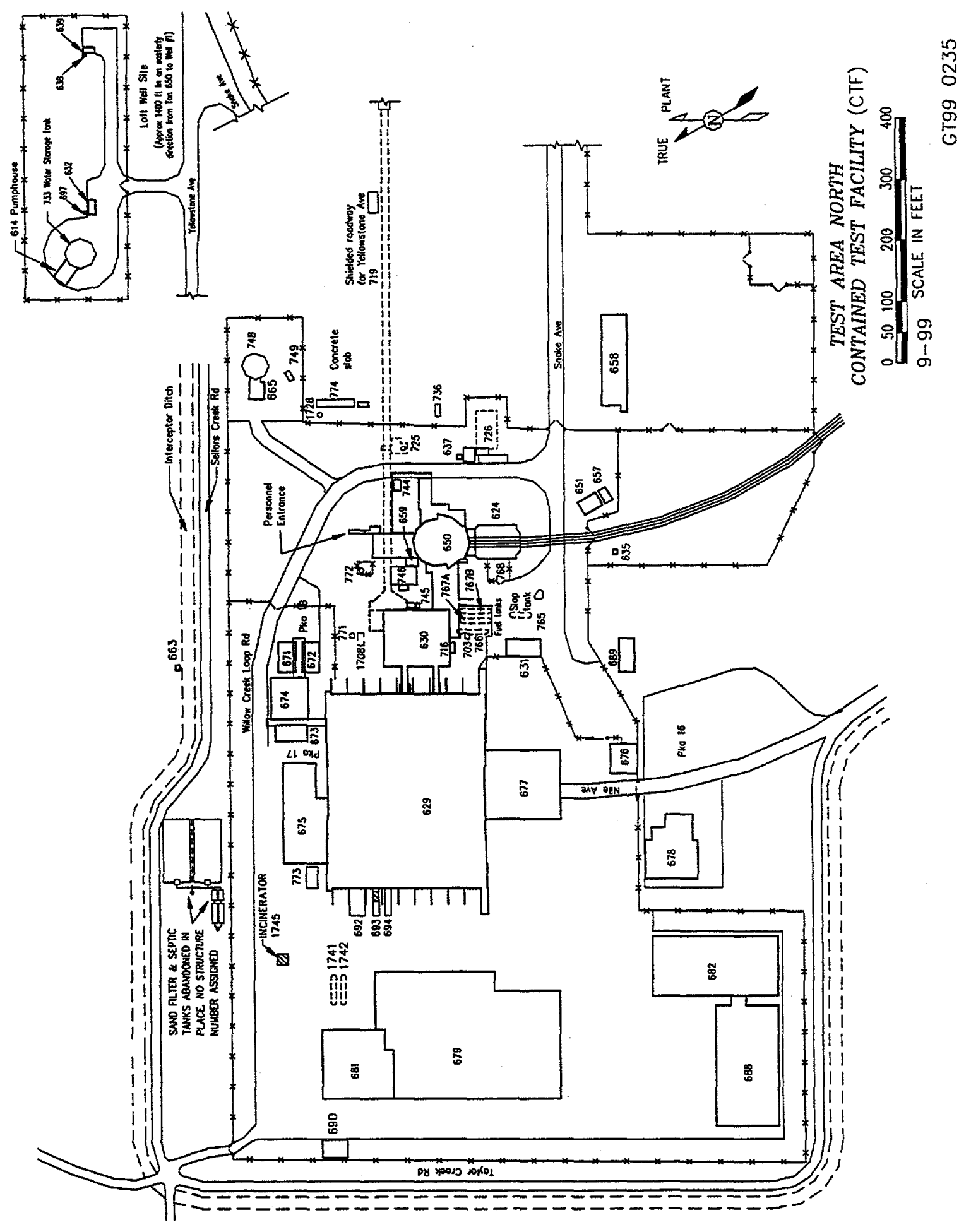

Figure 18. Area plot plan of Loss of Fluid Test and Specific Manufacturing Capability Area. 


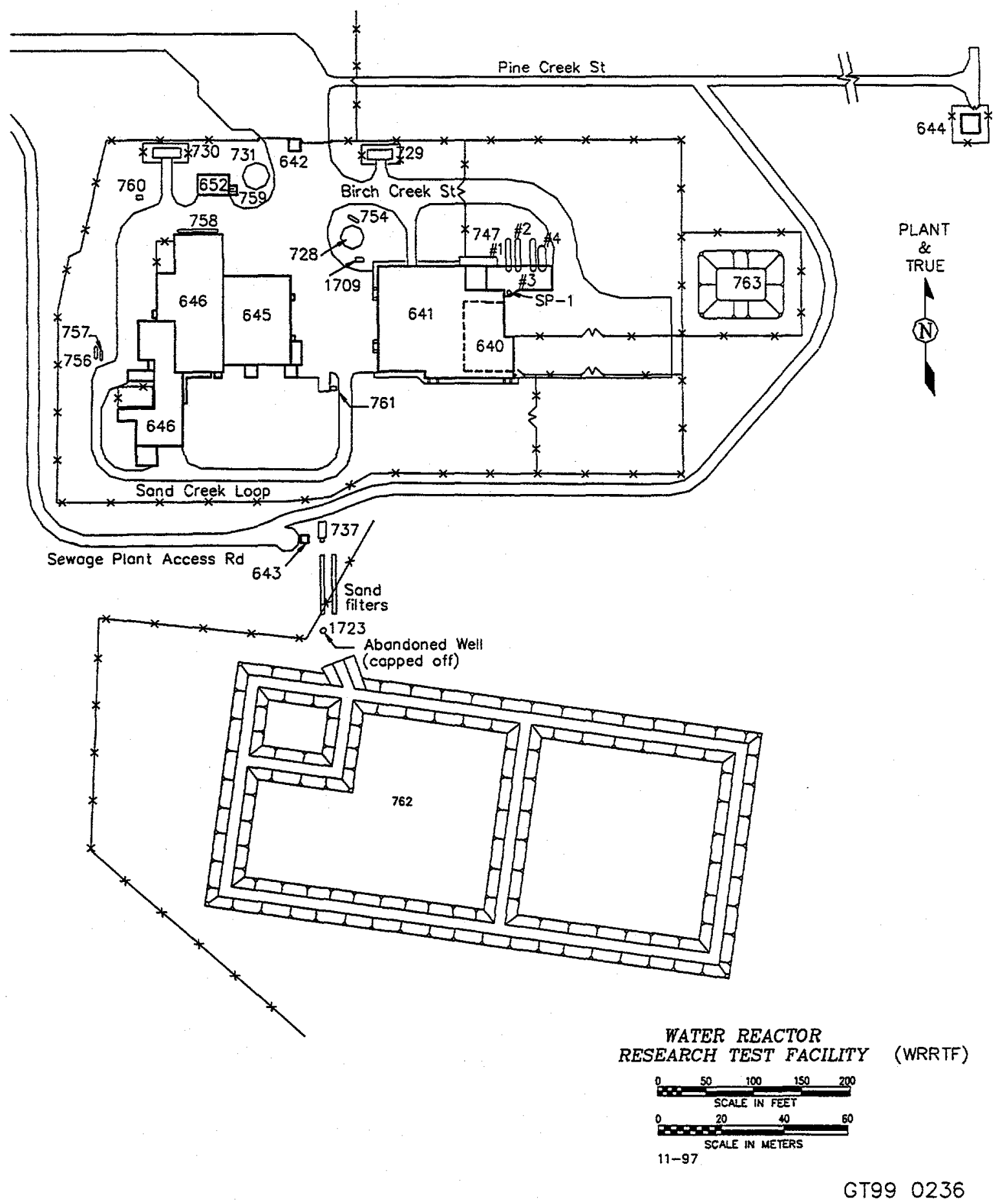

Figure 19. Area plot plan of Water Reactor Research Test Facility. 
Significant sources at LOFT, aside from the boilers, include several sources at SMC, in buildings TAN-629 (the hangar), TAN-679, and TAN-681. Emissions from these stacks include radionuclides from depleted uranium, particulates, nitrogen oxides, and some organics. Since the SMC Project is responsible for all of the activity at the LOFT Area, a thorough description of SMC is provided here.

The SMC Project assembly is a multi-phased project that includes fabrication, process reclamation, research and development, analytical lab facilities, and maintenance/utility support facilities. The SMC Project builds armor assemblies from various materials, including depleted uranium. The SMC Project produces emissions from chemical and manufacturing process, boilers, storage tanks, emergency generators, and miscellaneous building vents.

The SMC Project consists of MDF, TAN-679 Fabrication, TAN-629 Assembly, and support facilities. The life of the SMC project is approximately 20 years. Thereafter, it will be decontaminated and decommissioned in accordance with $\mathrm{DOE}$ requirements.

MDF is located in TAN-607A at the TSF area of TAN, approximately one mile southeast from the main SMC facilities. A portion of TAN-607 was designated for use as the MDF facility. MDF is primarily a research and development facility and involves fabrication and assembly operations to produce test size armor assemblies. The process utilizes standard metal working equipment such as punches, shears, brakes, and lasers. About 31,000 square feet is available and includes research and development processes, an analytical laboratory, and a maintenance and machine shop. This area will be closed in 1998. Specific equipment and operations will be moved to TAN-629 and TAN-679.

SMC Assembly facilities, located within TAN-629, contain manufacturing processes and space for offices, support functions (e.g., Health Physics, field laboratory), and service areas. Manufacturing processes are semi-automated systems that manufacture products similar to those manufactured in the MDF facility on an automated basis to produce full-scale armor assemblies at a higher throughput. Total square footage in TAN-629 for SMC use is about 80,000 square feet.

SMC TAN-679 Rolling Operation facilities consist of a manufacturing area, assembly processes, and a Process Reclamation Facility. This facility includes a rolling process that produces feedstock for TAN-629 operations. TAN-679 operations include 64,000 square feet area which includes a production facility; shipping and receiving, a Health Physics field office, maintenance area, boiler/utilities area, computer room, administrative offices, and change room facilities. In addition, space is provided for other support requirements such as a tool room, rest rooms, and a lunchroom.

The Process Reclamation Facility (PRF), adjoining the northwest wall of TAN-679, is a 12,000 square feet building and is used for collection and recycling of liquid wastes generated in TAN-679 production processes. Liquid wastes, generated in the North process area are transferred to the PRF facility for processing as required for recycling. All liquid wastes are collected in storage tanks for treatment. Nitrogen oxide gas streams from the acid bath are piped to the Process Reclamation Facility for processing through a wet scrubber and filters before release to the atmosphere. Nitric acid was generated during calendar year 1997 from calcining processes operated in the PRF facility. The calciner(s)ceased operation in 1998, hence nitric acid in no longer generated from stack Tan-681-012. 
There are no significant emission sources at the WRRTF other than the boilers.

Table 20. Significant sources at TAN.

\begin{tabular}{llll}
\hline $\begin{array}{l}\text { Building } \\
\text { number }\end{array}$ & Building name & $\begin{array}{c}\text { Vent/stack } \\
\text { number }\end{array}$ & Source description \\
\hline TAN-603 & Boiler Bldg. & -022 & 42.8 MBtu Boiler \\
TAN-603 & Boiler Bldg. & $-027^{\mathrm{a}}$ & 20.9 MBtu Boiler \\
TAN-603 & Boiler Bldg. & $-028^{\mathrm{a}}$ & 20.9 MBtu Boiler \\
TAN-606 & Maint. Bldg. & $-005^{\mathrm{a}}$ & Carpenter Shop \\
TAN-606 & Maint. Bldg. & $-026^{\mathrm{a}}$ & Paint Shop \\
TAN-606 & Maint. Bldg. & $-027^{\mathrm{a}}$ & Paint Shop \\
TAN-607A & Mat. Dev. Fac. & $-119^{\mathrm{a}}$ & Anal. Lab \\
TAN-607A & Mat. Dev. Fac. & $-039^{\mathrm{a}}$ & R\&D Lab \\
TAN-629 & Fab. and Ass'y & $-002^{\mathrm{a}}$ & Laser Ops. \\
TAN-629 & Fab. and Ass'y & $-012^{\mathrm{a}}$ & 2B Painting Operation \\
TAN-629 & Fab. and Ass'y & $-014^{\mathrm{a}}$ & 2B Painting Operation \\
TAN-641 & Boiler Bldg. & -034 & 6.28 MBtu Boiler \\
TAN-641 & Boiler Bldg. & -035 & 6.28 MBtu Boiler \\
TAN-679 & Boiler Bldg. & $-067^{\mathrm{a}}$ & 25 MBtu Boiler \\
TAN-679 & Boiler Bldg. & $-068^{\mathrm{a}}$ & 25 MBtu Boiler \\
TAN-681 & Proc. Waste Reclamation & $-012^{\mathrm{a}}$ & Nitric acid stack \\
TAN-681 & Incinerator & $-023^{\mathrm{a}}$ & Incinerator \\
\hline
\end{tabular}

a. This source consumes PSD increment.

\subsubsection{Not Significant Sources}

TAN has a wide variety of not significant sources, including chemical sources, fuel burning equipment, organic and inorganic storage tanks, and fugitive sources. Chemical sources include fumehoods, paint booths, welding booths, a blue print machine, two chemical mixing tanks, and several miscellaneous sources. Not significant fuel burning equipment includes emergency generators and a heater/furnace. 
Table 21. Not significant sources at TAN.

\begin{tabular}{|c|c|c|c|}
\hline $\begin{array}{l}\text { Building } \\
\text { number }\end{array}$ & Building name & $\begin{array}{c}\text { Vent/stack } \\
\text { number }\end{array}$ & Source description \\
\hline TAN-603 & Dispensary/Boiler Fac & -011 & $665 \mathrm{hp} \mathrm{Standby} \mathrm{generator}$ \\
\hline TAN-604 & Maintenance Shop & -022 & Welding Shop \\
\hline TAN-604 & Maintenance Shop & $-029,-031$ & Paint Shop \\
\hline TAN-607A & Material Dev. Fac. & -119 & Anal. Laboratory \\
\hline TAN-607A & Material Dev. Fac. & -039 & R\&D Laboratory \\
\hline TAN-607A & Material Dev. Fac. & $-041^{a}$ & Welding Shop \\
\hline TAN-607 & Hot Shop & -046 & $1,464 \mathrm{hp}$ Standby generator \\
\hline TAN-607 & Hot Shop & -047 & 1,000 gal AST \#2 Diesel Fuel tank \\
\hline TAN-610 & Pump house & -001 & 300 gal AST \#2 Diesel Fuel Tank \\
\hline TAN-610 & Pump house & -002 & 310 hp Standby Water Pump \\
\hline TAN-636 & Carpenter Shop & -002 & Carpenter Shop \\
\hline TAN-652 & Pump house & -002 & 185 gal Inside \#2 Diesel Fuel Tank \\
\hline TAN-652 & Pump house & -003 & $310 \mathrm{hp} \mathrm{Standby} \mathrm{Water} \mathrm{Pump}$ \\
\hline TAN-665 & Pump house & -001 & 300 gal Inside \#2 Diesel Fuel Tank \\
\hline TAN-665 & Pump house & -002 & $310 \mathrm{hp}$ Standby Water pump \\
\hline TAN-675 & Boiler House & -013 & 400 gal Inside \#2 Fuel Oil Tank \\
\hline TAN-675 & Boiler House & $-010^{a}$ & $598 \mathrm{hp} \mathrm{Standby} \mathrm{gen.}<200 \mathrm{hr} / \mathrm{month}$ \\
\hline TAN-677 & Truck Receiving & $-030^{a}$ & Welding Shop \\
\hline TAN-679 & Rolling Ops. Fac. & $-012^{a}$ & $890 \mathrm{hp} \mathrm{Standby} \mathrm{generator}$ \\
\hline TAN-681 & Tank & -004 & 48,000 gal UST \#2 Fuel Oil Tank \\
\hline TAN-681 & Tank & -004 & 48,000 gal UST \#2 Fuel Oil Tank \\
\hline TAN-679 & Tank & -069 & 400 gal Inside \#2 Fuel Oil Tank \\
\hline TAN-679 & Tank & -084 & 200 gal Inside \#2 Fuel Oil Tank \\
\hline TAN-687 & Fire Station & -008 & 500 gal Inside \#2 Fuel Oil Tank \\
\hline TAN-687 & Fire Station & $-020^{\mathrm{a}}$ & $99 \mathrm{hp} \mathrm{Standby} \mathrm{generator}$ \\
\hline TAN-701 & Water Tank & -001 & TCE sparger \\
\hline TAN-702 & Diesel Tank & $-001,-002$ & 120,000 gal AST $\# 2$ Diesel Fuel \\
\hline
\end{tabular}


Table 21. Not significant sources at TAN.

\begin{tabular}{llcl}
\hline $\begin{array}{l}\text { Building } \\
\text { number }\end{array}$ & Building name & $\begin{array}{c}\text { Vent/stack } \\
\text { number }\end{array}$ & Source description \\
\hline TAN-724 & Diesel Tank & -001 & 200,000 gal AST. \#2 Diesel Fuel \\
TAN-704 & Diesel Tank & -001 & 200,000 gal AST \#5 Diesel Fuel \\
TAN-738 & Diesel Tank & -738 & 6,000 gal UST \#2 Fuel Oil \\
TAN-753 & Fuel Oil Tank & -001 & Fuel Oil \\
TAN-759 & Diesel Tank & -001 & 185 gal AST \#1 Diesel Fuel \\
TAN-766 & Diesel Tank & -001 & 400 gal AST \#2 Diesel Fuel \\
TAN 767 & Diesel Tank & A, B-001 & 35,000 gal UST \#2 Diesel Fuel \\
TAN-783 & Gasoline Tank & -001 & 12,000 gal UST. Gasoline \\
TAN-787 & Fuel Oil Tank & -001 & 10,000 gal UST \#2 Fuel Oil \\
TAN-792 & Diesel Tank & -001 & 10,000 gal UST \#1 Diesel Fuel \\
TAN-1734 & Diesel Tank & -001 & 1,000 gal UST \#2 Diesel Fuel \\
(TAN-794) & & & \\
TAN-1734 & Diesel Tank & -001 & 1,000 gal UST \#2 Diesel Fuel \\
(TAN-797) & & &
\end{tabular}

a. This source consumes PSD increment and is individually reported.

\subsubsection{Summary of TAN Emissions}

Totals of each of the nonradionuclide principal pollutant emissions from sources at TAN during 1998 are summarized in Table 22.

Table 22. Summary of nonradionuclide principal pollutants at TAN.

\begin{tabular}{|c|c|c|}
\hline \multicolumn{3}{|c|}{ Emissions } \\
\hline Pollutant & $\begin{array}{c}\text { Hourly } \\
\mathrm{lb} / \mathrm{hr}\end{array}$ & $\begin{array}{c}\text { Annual } \\
\text { ton/yr }\end{array}$ \\
\hline Carbon monoxide & $2.0 E+00$ & $6.0 \mathrm{E}-01$ \\
\hline Nitrogen oxides & $8.2 E+00$ & $5.6 \mathrm{E}+00$ \\
\hline PM-10 & $6.3 \mathrm{E}-01$ & $7.9 \mathrm{E}-01$ \\
\hline Sulfur oxides & $5.6 \mathrm{E}+01$ & $1.7 E+01$ \\
\hline VOC - nonmethane & $4.2 E+01$ & $4.0 \mathrm{E}+00$ \\
\hline
\end{tabular}




\subsubsection{Summary of TAN Changes}

Changes to sources located at TAN are summarized in Table 23. Justification to changes are provided to clarify the status of the source.

Table 23. Summary of source changes at TAN - 1997 to 1998 inventory.

Emission source

TAN Hydrolysate Destruction Tests

TAN-607 Evaporation of radioactive water

TAN-607 Dismantling PBF Severe Fuel Damage Experiment

SMC TAN-681 Crane exhaust Vent High pressure water jet
Emissions consist of water and radioactivity. Water is not regulated and the radioactivity is reported under NESHAP regulations for radioactivity (APAD \# 98-009

Description

Water emissions are not regulated and the radioactivity falls under NESHAP radioactive emissions (APAD \# 98-011)

Emission of lead vapor are negligible during the dismantling (APAD \# 98-057)

Replaces a nitric acid cleaning system with the high pressure water jet. Eliminated nitric acid emissions.(APAD \# 98-019) 


\subsection{Test Reactor Area}

\subsubsection{Area Description}

TRA contains nuclear reactors used for testing fuel, materials, and reactor components in the highneutron environment that can be obtained in the reactors. Three primary test reactors have operated in this area: The Materials Testing Reactor (MTR), the Engineering Test Reactor (ETR), and the Advanced Test Reactor (ATR). Of these reactors, only the Advanced Test Reactor is presently operating or planned to be operated. In addition to the three test reactors, this area contains support facilities for the work routinely conducted in this area, including chemistry laboratories, hot cells for the examination of highly radioactive materials, maintenance shops, water purification facilities, and other facilities, some of which are currently being decommissioned.

Each reactor has a main stack from which air emissions from that reactor are discharged. This effluent consists of air from the reactor building ventilation systems, sampling stations, reactor access areas, fuel storage areas (underwater), and reactor coolant water degassing areas. Since both the Materials Testing Reactor and the Engineering Test Reactor are no longer operating, effluent from these sources are minimal. Most of the emissions are noble gases from the Advanced Test Reactor degassing. Some of the activity is formed when air or other gases become irradiated by the neutron flux in the Advanced Test Reactor. Figure 20 shows a plot plan of the TRA.

\subsubsection{Significant Source Descriptions}

The nonradionuclide significant sources consist of three diesel powered electric generators and the ATR cooling tower. These sources are listed in the following table.

Table 24. Significant emission sources at TRA.

\begin{tabular}{llll}
$\begin{array}{l}\text { Building } \\
\text { number }\end{array}$ & Building name & $\begin{array}{c}\text { Vent/stack } \\
\text { number }\end{array}$ & Source description \\
\hline TRA-670 & ATR Building & TRA-670-046 & Diesel exhaust \\
TRA-670 & ATR Building & TRA-670-053 & Diesel exhaust \\
TRA-674a & Diesel Generator Building & TRA-674-007 & Diesel exhaust \\
TRA-771 & ATR Cooling Tower & TRA-771-001 & Cooling tower \\
\hline
\end{tabular}

a. This source consumes a prevention of significant deterioration (PSD) increment. 


\subsubsection{Not Significant Sources}

TRA has numerous radiological sources, including radiological laboratories used for research and analysis, that also have nonradiological emissions. Those sources that are "radiological only" are not listed here. VOCs in the storage tanks include diesel fuel and unleaded gasoline. The fuel burning equipment includes two large diesel generators at the Advanced Test Reactor facility, two standby diesel generators, and two standby diesel water pumps, and one standby diesel compressor. The inorganic storage tanks contain sulfuric acid and sodium hydroxide. These materials are used in the demineralization system and for the cooling tower system. 


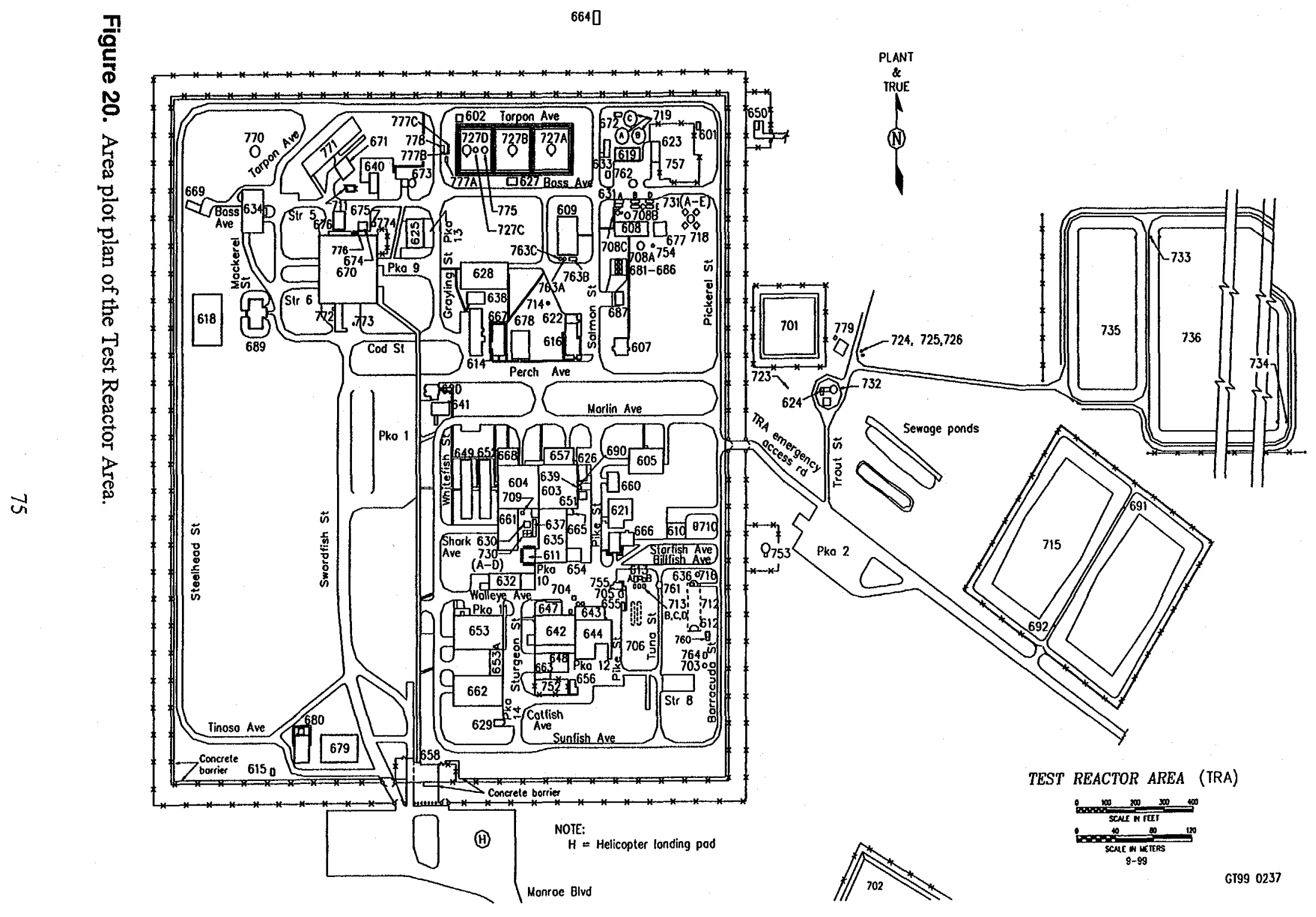


Table 25. Not significant sources at TRA.

\begin{tabular}{|c|c|c|c|}
\hline $\begin{array}{l}\text { Building } \\
\text { number }\end{array}$ & Building name & $\begin{array}{l}\text { Vent } \\
\text { number }\end{array}$ & Source description \\
\hline TRA-604 & MTR Building & 035 & Analytical/research labs \\
\hline TRA-604 & MTR Building Wing "A" & 072 & Analytical/research labs \\
\hline TRA-604 & MTR Building Wing "A" & 073 & Analytical/research labs \\
\hline TRA-604 & MTR Building Wing " $\mathrm{A}$ " & 074 & Analytical/research labs \\
\hline TRA-604 & MTR Building Wing "A" & 077 & Analytical/research labs \\
\hline TRA-607 & TRA Carpenter Shop & $010^{a}$ & Cyclone exhaust \\
\hline TRA-608 & Demineralizer Building & 005 & Tank vent \\
\hline TRA-608 & Demineralizer Building & 008 & Tank vent \\
\hline TRA-608 & Demineralizer Building & 012 & Tank vent - sodium hydroxide \\
\hline TRA-608 & Demineralizer Building & 013 & Tank vent - sulfuric acid \\
\hline TRA-609 & Steam Plant & $609-\mathrm{A}$ & Paint shop \\
\hline TRA-614 & Maintenance, Office, Bunkhouse & 032 & Parts cleaning \\
\hline TRA-619 & Raw Water Pump house & 006 & 300 gal diesel day tank \\
\hline TRA-619 & Raw Water Pump house & $008^{a}, 009$ & $558 \mathrm{hp}$ emergency firewater pump \\
\hline TRA-625 & Maintenance Support Bldg & 015 & Maintenance/fabrication shop \\
\hline TRA-633 & Fire Water Pump house & 002 & 660 gal diesel day tank \\
\hline TRA-633 & Fire Water Pump house & $003 \& 004$ & $558 \mathrm{hp}$ firewater pump \\
\hline TRA-653 & Maintenance Building & 028 & Maintenance welding \\
\hline TRA-660 & Reactivity Measurement Facility & 004 & Analytical/research labs \\
\hline TRA-661 & New Laboratory Addition & 008 & Analytical/research labs \\
\hline TRA-668 & MTR North Wing Extension & 013 & Analytical/research labs \\
\hline TRA-668 & MTR North Wing Extension & 015 & Analytical/research labs \\
\hline TRA-670 & ATR & 044 & 1,500 gal diesel tank \\
\hline TRA-670 & Storage Tank & 048 & 10-gal diesel starting tank \\
\hline TRA-670 & ATR Laboratory & 074 & Analytical/research labs \\
\hline TRA-670 & ATR Laboratory & 086 & Analytical/research labs \\
\hline TRA-670 & ATR Laboratory & 098 & Analytical/research labs \\
\hline TRA-670A & Standby Compressor & $001^{\mathrm{a}}$ & 174 hp standby diesel compressor \\
\hline TRA-670A & Storage Tank & 002 & Diesel day tank \\
\hline
\end{tabular}


Table 25. Not significant sources at TRA.

\begin{tabular}{|c|c|c|c|}
\hline $\begin{array}{l}\text { Building } \\
\text { number. }\end{array}$ & Building name & $\begin{array}{l}\text { Vent } \\
\text { number }\end{array}$ & Source description \\
\hline TRA-671 & ATR Cooling Tower Pump house & 010 & Inorganic tank vent -Sulfuric acid \\
\hline TRA-671 & ATR Cooling Tower Pump house & 011 & $\begin{array}{l}\text { Storage tank vent for Performax } 403 \text { - } \\
\text { dispersant }\end{array}$ \\
\hline TRA-671 & ATR Cooling Tower Pump house & 012 & $\begin{array}{l}\text { Storage tank vent for DREW 6066- } \\
\text { CO-Reactant Acid }\end{array}$ \\
\hline TRA-671 & ATR Cooling Tower Pump house & 013 & $\begin{array}{l}\text { Storage tank vent for DREW 3025- } \\
\text { Chlorine Dioxide Precursor }\end{array}$ \\
\hline TRA-671 & ATR Cooling Tower Pump house & 014 & $\begin{array}{l}\text { Storage tank vent for Performax } 4050 \text { - } \\
\text { commercially available corrosion } \\
\text { inhibitor. }\end{array}$ \\
\hline TRA-674 & Diesel Generator & 005 & 280 gal M-46 diesel day tank \\
\hline TRA-677 & Demineralized Water Facility & 001 & Tank vent \\
\hline TRA-677 & Demineralized Water Facility & 002 & Tank vent \\
\hline TRA-680 & Emergency Command Center & $001^{\mathrm{a}}$ & $210 \mathrm{hp} \mathrm{standby} \mathrm{diesel} \mathrm{generator}$ \\
\hline TRA-680 & Emergency Command Center & 002 & 300 gal diesel tank \\
\hline TRA-727C & Storage Tank & 003 & 30,000 gal diesel storage tank \\
\hline TRA-727D & Storage Tank & 004 & 92,000 gal diesel storage tank \\
\hline TRA-731B & Storage Tank & 002 & Sodium hydroxide tank vent \\
\hline TRA-737D & Storage Tank & 002 & Sulfuric acid tank vent \\
\hline TRA-775 & Storage Tank & 001 & 37,000 gal diesel storage tank \\
\hline TRA-776 & Storage Tank & 001 & 1,500 gal diesel day tank \\
\hline TRA-777B & Gasoline Tank & 001 & 2,500 gal gasoline tank \\
\hline TRA-777C & Diesel Tank & 001 & 10,000 gal diesel tank \\
\hline
\end{tabular}

a. This source consumes a prevention of significant deterioration increment.

\subsubsection{Summary of TRA Emissions}

Totals of each of the nonradionuclide principal pollutant emissions from sources at TRA during 1998 are summarized in Table 26. 
Table 26. Summary of nonradionuclide principal pollutants at TRA.

\begin{tabular}{lcc} 
Pollutant & \multicolumn{2}{c}{ Emissions } \\
Hourly & $\mathrm{b} / \mathrm{hr}$ & $\begin{array}{c}\text { Annual } \\
\text { ton/yr }\end{array}$ \\
\hline Carbon monoxide & $1.7 \mathrm{E}+01$ & $1.8 \mathrm{E}+01$ \\
Nitrogen oxides & $6.5 \mathrm{E}+01$ & $7.1 \mathrm{E}+01$ \\
PM-10 & $2.1 \mathrm{E}+00$ & $4.0 \mathrm{E}+00$ \\
Sulfur oxides & $1.0 \mathrm{E}+01$ & $1.1 \mathrm{E}+01$ \\
VOC - nonmethane & $1.6 \mathrm{E}+00$ & $3.0 \mathrm{E}+00$
\end{tabular}

\subsubsection{Summary of TRA Changes}

Changes to specific sources located at TRA between the 1997 and 1998 Air Emissions Inventories are summarized in Table 27 . Justification to changes are provided to clarify the status of the source.

Table 27. Summary of source changes at TRA - 1997 to 1998 inventory.

\begin{tabular}{ll}
\hline Emission Source & \multicolumn{1}{c}{ Description } \\
\hline $\begin{array}{l}\text { TRA Fire and Life Safety } \\
\text { Improvements }\end{array}$ & $\begin{array}{l}\text { A Category II Director's Exemption from requiring an Air } \\
\text { Operating Permit Certificate (APAD \# 98-028) }\end{array}$ \\
$\begin{array}{ll}\text { TRA 688 Install two 750 hp } \\
\text { diesel firewater pumps }\end{array}$ & $\begin{array}{l}\text { An IDAPA Director's Exemption to a PTC is being requested } \\
\text { (ADAP \# 98-023) }\end{array}$ \\
TRA -771 & $\begin{array}{l}\text { Changed drift fraction from 0.3\% to 0.005\% a } \\
\text { The change better represents the actual Cooling Tower operation }\end{array}$
\end{tabular}

a) Emissions $=($ drift fraction $)($ Cooling Tower flow rate $)($ solids conc. $)($ operations time $)$

Drift fraction $=0.005 \%$

Flow rate $=30,000 \mathrm{gpm}$

Solids concentration $=1.2 \mathrm{~g} / \mathrm{L}$

1998 operating time $=5,111 \mathrm{hr}$ 


\subsection{Emissions not reported in the AEI}

The AEI does not include emissions from the following sources:

- Mobile equipment (cars, buses)

- Ozone depleting substances

- Landfarming (VOC)

- Sewage and sewage treatment

- Facilities in Idaho Falls

- A comprehensive HAPs and TAPs inventory for all emission sources is not completed

- Drinking water treatment (chlorine, demineralizer and ion exchange treatments).

- Exempt insignificant activities. The AEI does not list or quantify emissions from sources associated with these categories. These categories are as follows:

1 Landscaping and ground keeping activities - INEEL landscaping activities include lawn care, plant care, small engine landscaping equipment, weed control, pest control, and general cleanup activities.

2 Janitorial activities - INEEL janitorial activities include general cleaning of INEEL structures and areas, general housekeeping, steam sterilizers, and wax application. Application of chemicals for cleaning purposes is included.

3 Cafeteria activities - INEEL cafeteria activities are preparation of meals by baking, frying, grilling, or any other means; cleanup of preparation areas; and cleaning of cafeteria utensils and equipment.

4 Personal care activities - INEEL personal care activities include lavatory activities, sewage lagoons and pumping stations, sewage treatment and disposal, laundering, and use of personal care items.

5 Office activities - INEEL office activities include general office support, printing operations, copy machines, blueprint machines, photographic laboratories, and office solid waste collection.

6 Safety activities - INEEL safety activities include safety, emergency response, and fire protection training fires, outdoors firearms practice ranges, relief valves, rupture discs, traffic flares, security training, and salting or sanding of winter road surfaces.

7 Maintenance activities - On location, INEEL maintenance activities include general structure maintenance (painting, welding, carpentry), roofing and roofing repair, machining, non-asbestos insulation, equipment cleaning and preservation, fuel burning equipment maintenance and overhaul activities, road maintenance and repair, parking lot maintenance and repair, and vehicle testing, maintenance, and repair.

8 Material storage - INEEL material storage includes any clothes containers, storage of laboratory chemicals, solid materials (dust-free handling), solid waste containers, paint storage and battery room exhausts. Material storage also includes storage tanks limited to storage of surfactants, lubricants, hydraulic fluid, butane, propane, liquefied petroleum gas, and cooking oils, and RCRA temporary accumulation areas. 
9 Plant support - INEEL plant support activities include drum handling and sampling, air compressors less than 100 horsepower, sand blasters, oil/water separators, nonprocess drying ovens, water treatment (slat bins, chlorination units, demineralizers, ion exchange, and regeneration of demineralizers and ion exchange), material testing, transformers, satellite accumulation areas, and reservoirs and pumping equipment limited to surfactants, lubricants, hydraulic fluid, cooking oils, hot cell window oil, and venting of buildings which house significant an nonsignificant sources/activities that have their own separate vents.

10 Medical care activities - INEEL medical activities include storage of medical supplies, use of chemicals to support medical activities, $x$-ray services, administering medications, and emergency medical operations.

11 Portable small (less than $100 \mathrm{hp}$ ) fuel burning equipment - INEEL small portable fuel burning equipment includes equipment available to borrow from the central equipment pool.

Although portable small fuel burning equipment is categorized as "Exempt insignificant activities" there was concern about their emissions due to the large number of such engines on INEEL. This AEI included emissions from small portable fuel burning equipment.

Emission factors for fuel burning equipment were taken from the latest AP-42 edition (10/96). This edition did not have emissions factors for trace metals in the following source categories.

a. Gasoline and diesel industrial engines (less than $600 \mathrm{hp}$ ) AP-42 Section 3.3

b. Large stationary diesel and all dual-fuel engines (greater than $600 \mathrm{hp}$ ) AP-42 Section 3.4

c. Small portable engines (no emission factors were available so AP-42 section 3.3 was used)

EPA is constantly reviewing air emission factors. For next years AEI additional sources for emission factors will be searched so that metal emissions from the above engines may be estimated.

The Clean Air Act contains a list of 188 hazardous chemicals and Idaho has a list of over 600 toxic air pollutants. This AEI reports emissions of both HAPs and some toxic air pollutants. Emissions sources releasing the greatest quantities of these chemicals were included in this years AEI. These sources include coal and fuel oil fired boilers, large stationary diesel engines, small gasoline and diesel engines and small portable fuel burning equipment. Laboratories also reported some hazardous and toxic chemical emissions.

This AEI attempted to include emissions of as many HAPs and toxic chemical releases as possible. However, this INEEL report does not include a comprehensive list of all HAPs and toxics. Areas that need to be evaluated for releasing these chemicals are the Calciner at INTEC, all on site laboratories and all fuel burning equipment including boilers, generators, engines and small portable fuel burning equipment. The AEI database must be modified to accept emission factors and release numbers below $1.0 \mathrm{E}-5$.

The AEI database currently does not contain a complete list of the HAP chemicals. Nor does it 
contain a comprehensive list for toxic air pollutants (TAPs). This was not important in past years since emission less than $1.0 \mathrm{E}-05 \mathrm{lb} / \mathrm{hr}$ or $1.0 \mathrm{E}-5 \mathrm{ton} / \mathrm{yr}$ were rounded to zero. Many of the HAPs and TAPs are below 1.0E-05. A complete list of all chemicals in the HAPs and TAPs categories will be included in the future AIE database.

Accurate release estimations can be obtained if fuels are sampled for metals, sulfur and nitrogen content. Current estimations routinely utilize upper concentration limits in fuels so that reported releases will be conservative reducing the possibility of under reporting emissions. This approach skews emission data and can result in reporting releases that are significantly higher than actual emissions. 


\section{EMISSION ESTIMATES FOR STATIONARY SOURCES}

The following sections describe the various calculations used to estimate the emissions from sources based on the data collected in the initial Phase II of the inventory and successive annual updates. Each section includes a list of assumptions made and calculational methods as applicable.

\subsection{Industrial Engine Emissions}

\subsubsection{Methodology and Assumptions}

Industrial stationary engines are commonly used throughout the INEEL for emergency electrical power generation and water pumping. These sources generally operate on a routine schedule of 0.5 hours per week. This routine operation and maintenance is required to ensure that the systems are ready when needed. The operation schedule during an emergency is dependent on the nature of the problem. Based on discussions with the maintenance personnel around the facility, the usual power outage lasts from 1 to 4 hours. Power outages occur infrequently and at any time, so a specific schedule is impossible to predict.

These calculations cover two basic categories of engines. These categories include diesel engines with power ratings up to $600 \mathrm{hp}$, and diesel engines with power ratings greater than $600 \mathrm{hp}$.

Emissions from these sources include;

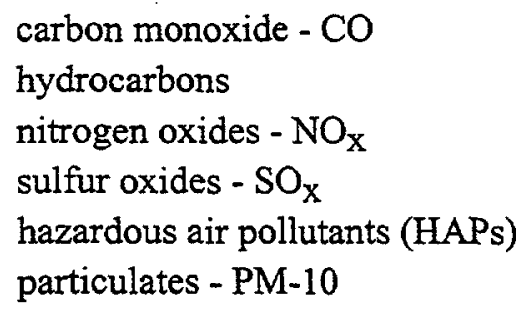

The emissions for these sources are estimated based on published emission factors found in EPA's AP-42 Volume I.

Assumptions:

a. Operation schedule was based on routine operation according to information supplied by maintenance personnel of 26 hours per year.

b. The primary method for estimating emissions was based on total horsepower and hours of operation.

c. Diesel fuel is assumed to have a maximum sulfur content of 0.5 weight percent. 
The following steps are required to estimate the emissions from industrial engines.

1. Determine engine size (horsepower).

2. Look up emission factors in AP-42 (10/96), Volume 1;

Less than $600 \mathrm{hp}$ engines:

Fuel input data Table 3.3-1

PM - $10 \quad$ Table 3.3-1

Organic compounds Table 3.3-2

Greater than $600 \mathrm{hp}$ engines:

$\mathrm{NO}_{\mathrm{X}}, \mathrm{SO}_{\mathrm{X}}, \mathrm{CO}$, Non-methane TOC - Table 3.4-1

VOCs - $\quad$ Tables 3.4-3 and 3.4-4

PM - 10

Table 3.4-5

Organic compounds Table 3.4-3

$\mathrm{PAH}$

Table 3.4-4

3. Apply emission factor to total horse-power and 26 hours or operation, and convert the units to tons per year.

\subsubsection{Calculations Performed by the Database}

The emission calculations for internal combustion engines (diesel) used the following equation:

$$
\left(\frac{\mathrm{gal}}{\mathrm{yr}}\right)\left(\frac{\mathrm{AP}-42, \mathrm{lb}}{1,000 \mathrm{gal}}\right)\left(\frac{\text { ton }}{2,000 \mathrm{lb}}\right)=\frac{\text { ton }}{\mathrm{yr}}
$$

Using the operation schedule provided on the data sheets, the hourly emissions were calculated as follows:

$$
\left(\frac{\mathrm{gal}}{\mathrm{hr}}\right)\left(\frac{\mathrm{AP}-42, \mathrm{lb}}{1,000 \mathrm{gal}}\right)=\frac{\mathrm{lb}}{\mathrm{hr}}
$$

\subsubsection{LMITCO Grouped Sources}

Sources that are not reported individually have been added to an area group source. These groups are described below. 
Area-GRP-1: All non-boiler fuel burning equipment

diesel

gasoline

fuel oil

propane

liquid natural gas

Area-GRP-2: Organic storage tanks

Area-GRP-3: Laboratories, fumehoods, paint shops, welding, craft and wood working shops

\subsubsection{Emission Estimates For Non Boiler Fuel Burning Grouped Sources}

LMITCO has significant and not significant diesel fuel burning standby generators, water pumps, and compressors. (Where equipment is used in a standby mode, emissions are grouped and not reported as individual sources.) The combined horsepower for equipment less than $600 \mathrm{hp}$ and greater than 600 $\mathrm{hp}$ were separately summed for each area. The resulting total horsepower were assumed to be operated for $26 \mathrm{hr}$ per year and using the appropriate AP-42 factor the emissions from these grouped equipment were calculated.

Emissions from all non-boiler fuel burning equipment, in each LMITCO area, are reported under the Area-GRP-001 source listing

\subsection{Boiler Emissions}

\subsubsection{Methodology and Assumptions}

Boilers are used throughout the INEEL primarily to provide space heating and process steam. Their fuels are natural gas, propane, fuel oil and coal. Boiler sizes range from residential sized heaters (less than $0.5 \mathrm{MBtu} / \mathrm{hr}$ ) to the large coal fired steam generation facility at INTEC (165 MBtu/hr). Boiler operation schedules vary depending on operations, weather, and reactor schedules. Because of the critical need for boilers in several areas, many boiler installations include up to $100 \%$ backup capacity for emergency purposes. These backup boilers are generally only operated for maintenance purposes. The best way to determine boiler use is to measure boiler fuel consumption. Fuel consumption automatically takes into account both hours of operation and boiler load. Fuel consumption figures are typically well documented and reliable.

Boiler emissions include carbon monoxide, nitrogen oxides, sulfur oxides, volatile organics, HAPs, and particulates. These emissions are estimated using published emission factors found in AP-42 (1/95). 
Assumptions:

a. Operation schedule is based on best estimates of boiler operators or maintenance staff.

b. Emission estimates are primarily based on the annual fuel consumption.

c. When several boilers have the same fuel source, the emissions for each boiler are based on the ratio of the individual capacity to the total capacity.

d. During the initial inventory process, the sulfur content for No. 2 fuel oil was considered to be 0.24 weight percent, and 0.9 weight percent for No. 5 fuel oil. However, per the present vendor contracts, the current emissions estimates use the sulfur content of No. 2 fuel oil as 0.5 weight percent and the sulfur content of No. 5 fuel oil as 1.75 weight percent.

In several instances, a boiler may burn a mixture of No. 1 fuel oil and No. 2 fuel oil; in such cases, the emissions estimates assumed all fuel burned was represented by No. 2 fuel oil.

The following steps are required to determine the emissions from boilers.

1. Determine fuel type (coal, oil, natural gas)

2. Determine boiler capacity (utility, industrial, commercial, residential)

3. Look up emission factor in AP-42 (10/96), Volume 1;

$$
\text { Fuel Oil Coal }
$$

$\begin{array}{lll}\mathrm{NO}_{\mathrm{X}}, \mathrm{SO}_{\mathrm{X}}, \mathrm{CO},- & \text { Table 1.3-1 } & \text { Table 1.1-3 } \\ \text { Non-methane VOC - } & \text { Table 1.3-2 } & \text { Table 1.1-18 } \\ \mathrm{PM}-10, & \text { Table 1.3-6 } & \text { Table 1.1-4 } \\ \text { Trace metals - } & \text { Table 1.3-9 } & \text { Table 1.1-17 }\end{array}$

Hexane and formaldehyde - EPA SPECIATE Data Base, profile 0001

4. Multiply emission factor by fuel consumed and correct units to $\mathrm{lb} / \mathrm{hr}$ or ton/year.

Boiler classification are based on the Btu rating of each boiler. The different ratings are:

$\begin{array}{lcc}\text { Utility } & >100 & \text { MBtu } \\ \text { Industrial } & 10-100 & \text { MBtu } \\ \text { Commercial } & 0.5-10 & \text { MBtu } \\ \text { Residential } & <0.5 & \text { MBtu }\end{array}$

The conversion from $\mathrm{lb} / \mathrm{MBtu}$ to $\mathrm{lb} /(\mathrm{hr}-\mathrm{hp})$ is: 


$$
\begin{aligned}
& \left(\frac{\mathrm{lb}}{\mathrm{MBtu}}\right)\left(\frac{\mathrm{MBtu}}{10^{6} \mathrm{Btu}}\right)\left(\frac{7000 \mathrm{Btu}}{\mathrm{hp} \times \mathrm{hr}}\right)=\frac{0.007 \mathrm{lb}}{\mathrm{hp} \times \mathrm{hr}} \\
& \left(\frac{\mathrm{lb}}{\mathrm{MBtu}}\right) \times 0.007=\frac{\mathrm{lb}}{\mathrm{hp} \times \mathrm{hr}}
\end{aligned}
$$

\subsubsection{Calculations Performed by the Database}

The emission calculations for boilers, heaters, and furnaces used the following equation: Using the operation schedule provided on the data sheets, the hourly emissions were calculated as follows:

yearly emissions $\rightarrow \quad\left(\frac{\mathrm{gal}}{\mathrm{yr}}\right)\left(\frac{\mathrm{AP}-42, \mathrm{lb}}{1,000 \mathrm{gal}}\right)\left(\frac{\text { ton }}{2,000 \mathrm{lb}}\right)=\frac{\text { ton }}{\mathrm{yr}}$

\subsection{Propane Burning Equipment}

LMITCO has approximately 60 propane burning equipment sources. These sources consist mainly of propane heaters. By looking at the number of propane burning equipment in each area the follow use factors were calculated:

$\begin{array}{ll}\text { CFA } & 34 \% \\ \text { INTEC } & 36 \% \\ \text { PBF } & 13 \% \\ \text { RWMC } & 17 \% .\end{array}$

By using the quantity of propane used at the site as a whole, allocating the percent used to each area, and then calculating the total emissions for each area provides a quick, fairly accurate method for determining emissions from propane. The 1998 propane use at the INEEL consisted of approximately 223,839 gallons $(133,478$ gal propane and 90,361 gal LNG). Emission calculations for this propane use is as follows:

yearly emissions $\rightarrow\left(\frac{\mathrm{gal}}{\mathrm{yr}}\right)\left(\frac{\mathrm{AP}-42, \mathrm{lb}}{1,000 \mathrm{gal}}\right)=\frac{\mathrm{lb}}{\mathrm{yr}}$

AP-42 factors Table 1.5-1, 10/96

PM $\quad 0.4 \mathrm{lb} / 1,000 \mathrm{gal}$

NOx $\quad 14.0 \mathrm{lb} /, 1000 \mathrm{gal}$

$\mathrm{CO} \quad 1.9 \mathrm{lb} / 1,000 \mathrm{gal}$

TOC $\quad 0.5 \mathrm{lb} / 1,000 \mathrm{gal}$ 
SOx $0.1 \mathrm{lb} / 1,000 \mathrm{gal}$

The AP-42 factor for sulfur oxides is, $\mathrm{SOx}=0.10 \mathrm{~S}$, where $\mathrm{S}$ is the sulfur content expressed in $\mathrm{gr} / 100$ $\mathrm{ft}^{3}$. Sulfur in propane seldom exceeds $1 \mathrm{gr} / 100 \mathrm{ft}^{3}$ (Perry, p. 9-16, $6^{\text {th }} \mathrm{Ed}$.). Assuming the sulfur content is $1 \mathrm{gr} / 100 \mathrm{ft}^{3}$ then the SOx factor would simply be $0.1 \mathrm{lb} / 1,000$ gallons $(0.10 \times 1)$.

Emissions are grouped with other fuel burning equipment emissions in sources Area-GRP-001.

\subsection{Laboratory Fumehood Calculations}

\subsubsection{Methodology and Assumptions}

There are approximately 60 not significant emission sources at the LMITCO areas associated with laboratories. These laboratories are used for chemical and physical analysis, radiological analysis, chemical storage, and research and development. The types of pollutants that may be involved in the laboratories include acids, bases, volatile organics, particulates, and a variety of other chemicals and gases that may or may not be of regulatory concern. The effort to track individual source emission was stopped in favor of using a combined estimate for the whole LMITCO areas. The combined VOC-nonmethane emissions from these laboratories is below 2 tons and is well below the 1 ton level for any individual HAP. A conservative estimate of 2 tons for VOC-nonmethane emission is used for the $1998 \mathrm{AEI}$. Emissions of HAPs are not described because of their low levels of release.

These VOC nonmethane emissions were allocated to the following areas at the given percentages based on the number of laboratories located in each area:

$\begin{array}{lrr}\text { CFA } & 18 \% & 720 \mathrm{lb} \\ \text { INTEC } & 38 \% & 1,520 \mathrm{lb} \\ \text { TAN } & 6 \% & 240 \mathrm{lb} \\ \text { TRA } & 38 \% & 1,520 \mathrm{lb}\end{array}$

Emissions are reported in the source listings of Area-GRP-003. 


\subsection{Organic Tank Emissions Calculations Methodology}

\subsubsection{Methodology and Assumptions}

INEEL storage tanks may be vertical or horizontal, above ground (AST)or underground (UST), and inside or outside buildings. The majority of the organic liquid storage tanks are vertical with a fixed roof. This type of tank consists of a cylindrical steel shell with a permanently affixed roof, which may vary in design from cone- or dome-shaped to flat. Fixed roof tanks at the INEEL are typically freely vented.

The INEEL methodology for estimating emissions for organic storage tanks is derived from EPA's AP-42, Compilation of Air Emission Factors For Stationary Sources, Section 4.3, "Storage of Organic Liquids." Emissions from tanks occur when the vapor space is either pressurized by a change in temperature or pressure, relieving the pressure by "breathing" out of the vent (breathing loss), or when the tank is filled, displacing the vapor out of the tank (working loss). Aboveground tanks are much more susceptible to daily temperature changes, and tank color and paint condition are therefore considered in calculating their emissions.

The INEEL, uses AP-42, Volume I, Section 4.3 (September 1985) to calculate the emissions from the storage of organic liquids. The INEEL Emissions Inventory System is programmed to perform these calculations. However, the EPA reissued the organic storage tank calculations in AP-42 Chapter 12. At the request of industry, the EPA redeveloped the complicated calculations to provide for easier calculations and to support the development of an EPA program to calculate storage tank emissions. Although the original calculations are more complex, the INEEL inventory system is programmed with and uses the more complex calculations for the 1998 Air Emissions Inventory.

The two types of emissions from fixed-roof, organic storage tanks are breathing loss and working loss. Breathing loss is the expulsion of vapor from a tank through vapor expansion and contraction because of changes in temperature and barometric pressure. Breathing loss does not change the liquid level in the tank. Working loss is the combined loss from filling and emptying tank contents. Filling loss comes with an increase of the liquid level in the tank, when the pressure inside the tank exceeds the relief pressure, or atmospheric pressure, and vapors are expelled from the tank. Emptying loss occurs when air drawn into the tank during liquid removal becomes saturated with organic vapor and expands, thus exceeding the capacity of the vapor space.

Above ground, horizontal organic storage tanks pose a unique problem from an AP-42 standpoint, since the empirical equation is specifically for vertical tanks. The equation considers the tank diameter as a function of the liquid surface area, but the diameter on a horizontal tank will have a much different effect on the surface area than will the diameter of a vertical tank. To correct for this, an average surface area is computed for horizontal tanks, and then an equivalent diameter factor is calculated based on that area. This diameter is then inserted into the AP-42 equation directly as though it was for a vertical tank. 
The following assumptions standardize the storage tank calculations.

1. Daily temperature change of underground tanks and inside tanks is approximately zero, and therefore the breathing loss is also approximately zero

2. Average atmospheric pressure is $12.3 \mathrm{psi}(635 \mathrm{mmHg})$

3. Working loss emissions are equal to volume of vapor displaced by fuel during tank filling. The number of times the tank is filled is assumed to be equal to the annual throughput divided by the volume of the tank

4. The vapor space height for horizontal cylindrical tanks is approximated as though the tank were of a square cross section. This greatly simplifies the calculation.

5. The maximum fill rates of the tanks were provided by the INEEL Idaho Traffic Division as follows:

a. aboveground tanks: trucks pump at $200 \mathrm{gal} / \mathrm{min}$

b. underground tanks: gravity fed at $100 \mathrm{gal} / \mathrm{min}$

c. CFA-754 and TAN-724: self pumping at $90 \mathrm{gal} / \mathrm{min}$.

\subsubsection{Emission Estimates From Grouped Sources}

The 1998 AEI has grouped all the LMITCO organic storage tank emissions by area. The 1998 fuel usage was within $8 \%$ of the 1997 quantities. Similar emission quantities are used for the tanks under 10,000 gallons as were provided in 1997. The estimated emissions are based on the results of previous years emissions that were determined by using the above mentioned methodologies. Emissions ( 0.4 ton of VOC) from the over 10,000 gallons were allocated on the following basis:

$1997 \mathrm{VOC}=800 \mathrm{lb}$

an $8 \%$ increase is $64 \mathrm{lb}$ for a total VOC of $864 \mathrm{lb}$

$\begin{array}{lrr}\text { CFA } & 23 \% & 199 \mathrm{lb} \\ \text { INTEC } & 28 \% & 242 \mathrm{lb} \\ \text { PBF } & 3 \% & 26 \mathrm{lb} \\ \text { TRA } & 13 \% & 112 \mathrm{lb} \\ \text { TAN } & 33 \% & 285 \mathrm{lb}\end{array}$

The emissions for each area are reported by the sources labeled Area-GRP-002. 


\subsection{Painting Operations Calculations}

\subsubsection{Methodology and Assumptions}

A variety of painting operations occur at the INEEL, including spray booths, brush applications inside craft shops, spraying and brushing on location, paint mixing, and brush/equipment cleaning. The paint booths are typically the only sources with a designated blower specific to that source. Any painting that occurs elsewhere in the shop is considered to be vented either from a nearby room exhaust, or through the paint booth, whichever is most appropriate.

For convenience, all painting that occurs on location around the INEEL is attributed to the paint shop that supplied the paint, and all emissions are assumed to vent with the paint booth. Shop managers and material safety data sheets provided information about the materials used in the paint booths.

Emissions estimates associated with painting operations were hand calculated and based on process knowledge of the given operation. The database does not provide calculations for these types of operations. The following assumptions were used where they were applicable.

Assumptions:

1. $100 \%$ of VOCs from paint is emitted.

2. $15 \%$ of paint solids are emitted from spraying activities.

3. $0 \%$ of solids are emitted from brush application activities.

4. $40 \%$ of lacquer thinner and other thinners are evaporated to the atmosphere $(60 \%$ is disposed of in satellite accumulation areas).

5. $10 \%$ of mineral spirits solvent is evaporated to the atmosphere $(90 \%$ is disposed of in satellite accumulation area).

6. All painting operations are associated with a vent.

7. $90 \%$ filter efficiency for particulate in a spray booth.

8. $0 \%$ filter efficiency for all volatile organic compounds, and for particulate from activities outside the spray booth. 
9. Typical operating schedule (if not provided by operator) is 4 hours/day, 5 days/week, 52 weeks/year, or 1,040 hours per year.

\subsubsection{Grouped Painting Sources}

There are less than 10 LMITCO sources associated with not significant painting activities that are not individually reported. These grouped sources have historically emitted less than 0.5 ton/yr of PM -10 and 3 ton/yr of VOC. Emissions from these sources are being reported on an area basis and have been allocated in the following percentages:

$\begin{array}{ll}\text { CFA } & 29 \% \\ \text { INTEC } & 29 \% \\ \text { TAN } & 29 \% \\ \text { TRA } & 13 \%\end{array}$

These emissions are reported as part of the group sources identified as Area-GRP-003.

\subsection{Emissions From Welding Operations}

\subsubsection{Methodology and Assumptions}

Welding operations are located at ANL-W, CFA, INTEC, NRF, and TAN. During welding, a percentage of the welding rod is deposited and the balance goes to fume. The fumes are then removed by the ventilation system and released to the atmosphere. To calculate the amount and composition of the fume released to the atmosphere, the type and amount of welding rod used per year at each welding operation, the percentage of welding rod used that goes to fume for each rod type, the composition of the fumes from each rod type, and the stack parameters of the ventilation systems information was collected.

The following assumptions were used if they were applicable.

Assumptions:

All fumes produced during welding are vented through the stack on the associated ventilation system

Fumes produced during tungsten inert gas welding are negligible (Barnes, Tak) and thus are not considered

The percent fume generated and fume constituents will be the same for welding rods of the same type but different manufacturers 
For modeling purposes, all welding fumes generated in a building will be vented to the atmosphere through one stack.

Formula:

$$
\begin{aligned}
& \text { Amount of rod used } \mathrm{x} \frac{\text { weight } \% \text { of fumes }}{100}=\text { fumes generated (lb) } \\
& \text { Fumes generated }(\mathrm{lb}) \times \frac{\text { weight } \% \text { of constituent }}{100}=\text { constituent generated }(\mathrm{lb}) \text {. }
\end{aligned}
$$

\subsubsection{Grouped Welding Sources}

There are 9 sources associated with not significant welding activities that are not individually reported. These sources have historically emitted less than 0.25 ton/yr of PM-10. These emissions are reported as part of the grouped emissions from LMITCO areas and have been allocated to the areas in the following percentages:

$\begin{array}{lrr}\text { CFA } & 38 \% & 190 \mathrm{lb} \text { PM-10 } \\ \text { INTEC } & 38 \% & 190 \mathrm{lb} \text { PM-10 } \\ \text { TAN } & 19 \% & 95 \mathrm{lb} \text { PM-10 } \\ \text { TRA } & 5 \% & 25 \mathrm{lb} \text { PM-10 }\end{array}$

These emission are being reported as part of the grouped sources labeled Area-GRP-003.

\subsection{Main Stacks}

\subsubsection{Methodology and Assumptions}

Main stacks are large emission points that consist of several effluent streams culminating in a single, typically very large stack, such as the INTEC Main Stack. Each main stack is unique: processes that it exhausts are peculiar to that stack alone. The general method used for determining the emissions from these sources is to track each individual effluent stream to its source and estimate the emissions. The main stack's emissions then are the sum of each contributing source. Main stack emission estimates were determined using :

Stack monitoring results

Process knowledge

Existing permits

Permit applications
Engineering drawings

Interviews with cognizant engineers

Calculations 


\subsection{Craft Shops}

Craft shops at the INEEL do a variety of maintenance and support activities including wood working, painting, and welding. Painting and welding have been addressed separately. There are 9 sources associated with not significant craft shops/wood working that are not individually reported. These sources have historically emitted less than 1.0 ton/yr of PM-10. This value is used for the LMITCO grouped craft shop sources and is included in the grouped sources labeled Area-GRP-003. Craft shops are located at CFA, INTEC, TAN and TRA and it was assumed that each facility emitted $500 \mathrm{lb}$ of PM-10.

\subsection{Inorganic Storage Tanks}

There are approximately 20 storage tanks associated with inorganics at the INEEL. Acids are stored in 7 of these tanks and bases are stored in the other 13. There are no emissions from the base solutions. The acid tanks contain nitric, sulfuric, or fluoric acids. Historically the emissions from the sulfuric acid tanks are less than $1 \mathrm{lb} / \mathrm{yr}$, and fluoric acid tank emissions are less than $20 \mathrm{lb} / \mathrm{yr}$. As described in the EPA SARA 313 report for the INEEL, nitric acid emissions from all sources at the INEEL are approximately 7,000 lb/yr if the INTEC calciner is not operating. In 1998 the calciner operated and the total nitric acid emissions were 43,754 lb (1998 EPCRA/SARA Form R). These nitric acid emissions are shown to be emitted from the CPP-708 Main Stack. The sulfuric and fluoric acid was included with group 3 at INTEC.

\subsection{Miscellaneous Sources}

\subsubsection{Methodology and Assumptions}

Occasionally during the inventory, a source was encountered that did not fit into any of the above categories. Each of these had to be handled on a case-by-case basis. Calculations were typically based on a set of assumptions that allowed these sources to be characterized in a fashion similar to other more familiar sources. These assumptions and calculations were documented and attached to the field data sheets. 


\subsubsection{Landfill Emissions}

LandGEM version 2.01 was used to model emissions coning from landfills at the INEEL. The model uses CAA and AP-42 factors for an arid environment and emission factors based on codisposal were used. Codisposal assumes the presence of hazardous pollutants. The LandGEM program estimate emissions of 47 chemicals some of which are hazardous air pollutants and volatile organic carbon.

\subsubsection{Emissions Reported Under Federal Regulations}

EPA has established regulations for the reporting of toxic chemicals. These reporting requirements are found under Section 313 of the Emergency Planning and Community Right-to-Know (EPCRA, or Title III of the Superfund Amendments and Reauthorization Act of 1986). The EPCRA Section 313 program is also referred to as the Toxics Release Inventory or TRI.

Emissions report by the REEL for CY-1998 are given in section 5 and 6.

Table 28. Emissions reported under EPCRA regulations for the INEEL during 1998.

\begin{tabular}{lccc}
\hline & \multicolumn{3}{c}{ Reported releases } \\
\cline { 2 - 4 } Chemical & $\begin{array}{c}\text { Fugitive } \\
\mathrm{lb}\end{array}$ & $\begin{array}{c}\text { Point } \\
\mathrm{lb}\end{array}$ & $\begin{array}{c}\text { Total } \\
1 \mathrm{~b}\end{array}$ \\
\hline Lead & 82 & 73 & 155 \\
Nitric acid & 20 & 43,734 & 43,754 \\
Nitrates & 0 & 0 & 0 \\
\hline
\end{tabular}

These emissions have been incorporated into the $1998 \mathrm{AEI}$. 


\subsection{Hazardous Air Emissions For The INEEL}

The Clean Air Act lists 188 chemicals as hazardous. This list of chemicals was used to identify emissions sources on the INEEL that had may have emitted any of these chemicals. The AEI database showed which of these chemicals were released in quantities greater than $0.002 \mathrm{lb} / \mathrm{yr}$. However, this system zeroed any emissions that were less than $0.002 \mathrm{lb} / \mathrm{yr}(1.0 \mathrm{E}-6 \mathrm{ton} / \mathrm{yr})$. This zeroing will be eliminate in next years report so that all emissions will be listed.

The 1998 report will include hand calculations for hazardous air pollutants released from the INEEL. This effort was undertaken to provide realistic estimations for any HAPs that may have been released.

\subsubsection{Methodology and Assumptions}

The hazardous air pollutants are created and emitted from a variety of processes. EPA has categorized many of the processes that release HAPs. Emission factors have been compiled which help estimate emissions from each source category. These factors are found in AP-42 (10/96). The INEEL has sources of HAPs that fall into the following applicable categories and emission factors were used from the tables below the category.

- Coal fired boilers

1.1-12 Emission factors for polynuclear aromatic hydrocarbons (PAH) from controlled coal combustion

1.1-13 Emission factors for various organic compounds from controlled coal combustion

1.1-17 Emission factors for trace metals from controlled coal combustion.

- Fuel oil boilers

1.3-8 Emission factors for speciated organic compounds from fuel oil combustion

1.3-9 Emission factors for trace elements from distillate fuel oil combustion sources

- Diesel engines and generators (less than $600 \mathrm{hp}$ )

3.3-1 Emission factors for uncontrolled gasoline and diesel industrial engines

3.3-2 Speciated organic compound emission factors for uncontrolled diesel engines

- Large diesel engines (greater than $600 \mathrm{hp}$ )

3..4-1 Gaseous emission factors for large stationary diesel and all stationary dual-fuel engines

3.4-2 Particulate and particle sizing emission factors for large uncontrolled stationary diesel engines

3.4-3 Speciated organic compound emission factors for large uncontrolled stationary diesel engines

3.4-4 PAH emission factors for large uncontrolled stationary diesel engines

- Small portable engines (less than $100 \mathrm{hp}$ ) No emission factors were available so the following were used.

3.3-1 Emission factors for uncontrolled gasoline and diesel industrial engines

3.3-2 Speciated organic compound emission factors for uncontrolled diesel engines

The NEEL uses distillate fuel oil in their fuel oil fired boilers. This fuel oil contains fewer impurities such as trace metals, sulfur, burn cleaner thereby producing fewer organic emissions. In the 
10/96 edition of the AP-42 factors there are no emission factors for speciated organic compounds. Most of these compound are HAPs. AP-42 did have emission factors for these organic pollutants for residual oil. For distillate boilers speciated organic emissions were calculated using the emission factors for this residual oil. The result is that these speciated organic emissions (HAPs) will be higher than what the INEEL actual released. It does however, provide an upper limit for these HAPs. The conclusion that may be drawn is that INEEL emissions of these organics are somewhere below the published values.

Small portable engines are exempt from emission reporting. AP-42 contains no emission factors for these small engines. Since the INEEL has a large number of these engines emissions from this source were estimated to determine what actual emissions may be.

Emissions from these small engines were calculated using the following assumptions.

Each facility was assumed to have 10 portable engines each operating 10 hours a week.
ANL 10 engines
CFA 10 engines
INTEC 10 engines
NRF 10 engines
PBF 10 engines
RWMC 10 engines
TAN 10 engines
TRA 10 engines
Total 80 engines

It was assumed that the average portable engine was $10 \mathrm{hp}$.

Since there are no emission factors for these engines the AP-42 factors for "Gasoline and diesel industrial engines" in section 3.3 were used.

The AEI for next year will review emission factors from multiple sources to obtain a better estimation for emissions associated with small engines. Additional information concerning the actual numbers of small engines, hp ratings and hours of operation would increase the accuracy of small engine emissions.

Emissions of lead and nitric acid were report by the INEEL under the EPCRA regulations. These emissions have been included in this years HAPs. Continued efforts will be taken to coordinate emission reporting under various laws and regulations to provide consistency and improve accuracy.

The EPA's list of 188 hazardous air pollutants contains a CAS number identification for each chemical. Future AEI reports will also provide chemical CAS numbers. This will reduce errors associated with chemical nomenclature, synonyms and chemical spelling differences. A list of the 188 HAP chemicals from the CAA is included in the Appendix, sorted alphabetically and by CAS number. 


\section{AIR EMISSION TABLES FOR 1998}

The primary emission gases are nitrogen oxides, sulfur oxides, PM-10, VOCNM and carbon monoxide. These gases represent the largest emission sources at the INEEL. Inaddition to these primary gases INEEL emissions also include hazardous air pollutants and metals. Many of the emissions were calculated using a spreadsheet so that all emissions could be calculated. This process allowed the reporting of emissions less than the 1.0E-5 AEI database cutoff. Therefore, the emission list has been expanded to include most chemicals regardless of how small the emissions are.

Emission summaries for the INEEL do not include hourly emission rates. Simply adding the emission rates for all sources of a particular chemical results in inaccurate and misleading hourly rates. Rates are skewed upward when a small source which operates for only a few days and has a high hourly emission rate is added to another source that has a low hourly rate but operates for the entire year. For example, an emission source has a rate for a certain chemical of $20 \mathrm{lb} / \mathrm{hr}$ and it operated for 5 days. A second emission point has an emission of $2 \mathrm{lb} / \mathrm{hr}$ but operated for the whole year. Adding the two hourly emission rates would give a rate of $22 \mathrm{lb} / \mathrm{hr}$. However, the source that operated for 5 days released 1.2 tons while the source that had a release rate of $2 \mathrm{lb} / \mathrm{hr}$ would have released 8.8 tons for the year.

For the purpose of the Air Emission Inventory, the INEEL is considered a single contiguous facility, even though the emission points are divided among distinct areas within the site. A few hourly rates have been provided for the primary pollutants nitrogen oxides, sulfur oxides, carbon monoxide, PM-10 and VOC-nonmethane. These rates help to approximate what the actual rates may be and are given for each facility (ANL-W, CFA, INTEC, NRF, TAN, TRA, PBF, RWMC). Reporting the rate of a chemicals emission on a facility bases helps to identify potential problems or errors.

\subsection{Listing of Emission Tables}

The following tables provide detailed information on air releases at the INEEL for 1998.

- Table 29. Descending rank of all air emissions from the NEEL for 1998.

- Table 30. Hazardous metal emissions from the INEEL for 1998.

- Table 31. Primary pollutant emissions from the INEEL for 1998.

- Table 32. Alphabetical list of all emissions from the INEEL for 1998.

- Table 33. Summary of principle pollutant emissions from the INEEL for 1998.

- Table 34. Summary of each principle pollutant by each area for 1998.

- Table 35. Emissions by area, building and vent number for 1998.

- Table 36. Descending rank of emissions for principle pollutants by area, building and vent.

- Table 37. Small portable fuel burning equipment emissions from the INEEL for 1998.

Some of the organic chemicals with numbers in their names have these numbers placed at the end on the chemical name. This allows alphabetical ordering based on the name and not the numbers. 
Table 29. Descending rank of all air emissions from the INEEL for 1998.

\begin{tabular}{|c|c|c|}
\hline Chemical & $\operatorname{ton} / \mathrm{yr}$ & $1 \mathrm{~b} / \mathrm{yr}$ \\
\hline Nitrogen oxides & $5.4 \mathrm{E}+02$ & $1,086,613$ \\
\hline Carbon monoxide & $2.8 \mathrm{E}+02$ & 569,708 \\
\hline Sulfur oxides & $1.8 \mathrm{E}+02$ & 362,414 \\
\hline VOCNM & $5.1 \mathrm{E}+01$ & 101,485 \\
\hline PM-10 & $3.2 E+01$ & 63,608 \\
\hline Nitric acid & $2.2 \mathrm{E}+01$ & 44,000 \\
\hline VOC-methane & $1.1 \mathrm{E}+01$ & 22,000 \\
\hline Carbon tetrachloride & $2.7 \mathrm{E}+00$ & 5,400 \\
\hline Hydrochloric acid & $2.0 \mathrm{E}+00$ & 4,000 \\
\hline 1,1,1-Trichloroethane & $2.0 \mathrm{E}+00$ & 3,930 \\
\hline Total Organic Compounds & $4.0 \mathrm{E}-01$ & 800 \\
\hline Chloroform & $1.0 \mathrm{E}-01$ & 200 \\
\hline Formaldehyde & $9.9 \mathrm{E}-02$ & 197 \\
\hline Lead & $8.0 \mathrm{E}-02$ & 160 \\
\hline Methyl alcohol & $7.0 \mathrm{E}-02$ & 140 \\
\hline Methylene chloride & $6.9 \mathrm{E}-02$ & 139 \\
\hline Propylene & $6.9 \mathrm{E}-02$ & 139 \\
\hline Trichloroethylene & $6.7 \mathrm{E}-02$ & 134 \\
\hline Toluene & $4.0 \mathrm{E}-02$ & 80 \\
\hline VOC vapors & $4.0 \mathrm{E}-02$ & 80 \\
\hline Benzene & $2.9 \mathrm{E}-02$ & 59 \\
\hline Magnesium & $2.8 \mathrm{E}-02$ & 56 \\
\hline Mercury & $2.4 \mathrm{E}-02$ & 48 \\
\hline Hexane & $2.3 \mathrm{E}-02$ & 46 \\
\hline Chromium & $1.2 \mathrm{E}-02$ & 25 \\
\hline Acetone & $1.0 \mathrm{E}-02$ & 20 \\
\hline Hydrofluoric acid & $1.0 \mathrm{E}-02$ & 20 \\
\hline Xylene & $8.0 \mathrm{E}-03$ & 16 \\
\hline Cyanide & $6.5 \mathrm{E}-03$ & 13 \\
\hline Acetaldehyde & $6.5 \mathrm{E}-03$ & 13 \\
\hline Manganese & $4.3 \mathrm{E}-03$ & 8.5 \\
\hline Nickel & 4.2E-03 & 8.4 \\
\hline Selenium & $4.0 \mathrm{E}-03$ & 7.9 \\
\hline Naphthalene & $3.1 \mathrm{E}-03$ & 6.1 \\
\hline Cadmium & $2.5 \mathrm{E}-03$ & 5.0 \\
\hline Fluorides & $2.4 \mathrm{E}-03$ & 4.8 \\
\hline Arsenic & $2.2 \mathrm{E}-03$ & 4.3 \\
\hline
\end{tabular}


Table 29. (continued).

\begin{tabular}{|c|c|c|}
\hline Chemical & ton/yr & $\mathrm{lb} / \mathrm{yr}$ \\
\hline Benzyl chloride & $1.8 \mathrm{E}-03$ & 3.5 \\
\hline Dichloromethane & $1.6 \mathrm{E}-03$ & 3.2 \\
\hline Isophorone & $1.5 \mathrm{E}-03$ & 2.9 \\
\hline Sulfur tetraoxide & $1.4 \mathrm{E}-03$ & 2.8 \\
\hline Methyl chloride & $1.3 \mathrm{E}-03$ & 2.7 \\
\hline Acrolein & $1.1 \mathrm{E}-03$ & 2.2 \\
\hline Chloride & $1.1 \mathrm{E}-03$ & 2.2 \\
\hline Ethyl benzene & $9.5 \mathrm{E}-04$ & 1.9 \\
\hline Propionaldehyde & $9.5 \mathrm{E}-04$ & 1.9 \\
\hline Perchloroethylene & $8.0 \mathrm{E}-04$ & 1.6 \\
\hline Beryllium & 7.2E-04 & 1.4 \\
\hline Bromochloromethane & $6.5 \mathrm{E}-04$ & 1.3 \\
\hline Vinyl chloride & $6.0 \mathrm{E}-04$ & 1.2 \\
\hline Carbon disulfide & $5.5 \mathrm{E}-04$ & 1.1 \\
\hline Acrylonitrile & $4.3 E-04$ & 0.86 \\
\hline Methyl hydrazine & $4.3 \mathrm{E}-04$ & 0.86 \\
\hline Methyl bromide & $4.0 \mathrm{E}-04$ & 0.81 \\
\hline 1,1-Dichloroethane & $3.8 \mathrm{E}-04$ & 0.75 \\
\hline Cobalt & $2.5 \mathrm{E}-04$ & 0.51 \\
\hline Antimony & $2.5 \mathrm{E}-04$ & 0.49 \\
\hline Methyl isobutyl ketone & $2.4 \mathrm{E}-04$ & 0.48 \\
\hline 1,1,2,2-Tetrachloroethane & $2.4 \mathrm{E}-04$ & 0.48 \\
\hline Silicon & $2.1 \mathrm{E}-04$ & 0.42 \\
\hline Barium & $2.0 \mathrm{E}-04$ & 0.40 \\
\hline Diethanolamine & $2.0 \mathrm{E}-04$ & 0.40 \\
\hline Iodine & $2.0 \mathrm{E}-04$ & 0.40 \\
\hline Iron oxide fume & $2.0 \mathrm{E}-04$ & 0.40 \\
\hline Silver metal & $2.0 \mathrm{E}-04$ & 0.40 \\
\hline Thallium & $2.0 \mathrm{E}-04$ & 0.40 \\
\hline Chromium vi & $2.0 \mathrm{E}-04$ & 0.40 \\
\hline Chloroethane & $1.9 \mathrm{E}-04$ & 0.38 \\
\hline Bis(2-ethylhexyl)phthalate(DEHP) & $1.8 \mathrm{E}-04$ & 0.37 \\
\hline Cumene hydroperoxide & $1.4 \mathrm{E}-04$ & 0.28 \\
\hline Diethyl phthalate & $1.4 \mathrm{E}-04$ & 0.28 \\
\hline Bromine & $1.3 \mathrm{E}-04$ & 0.26 \\
\hline Zinc & $1.3 \mathrm{E}-04$ & 0.26 \\
\hline Tetrachloroethylene & 1.3E-04 & 0.26 \\
\hline Phenanthrene & $1.3 \mathrm{E}-04$ & 0.25 \\
\hline
\end{tabular}


Table 29. (continued).

\begin{tabular}{|c|c|c|}
\hline Chemical & $\operatorname{ton} / \mathrm{yr}$ & $\mathrm{lb} / \mathrm{yr}$ \\
\hline Dimethyl sulfate & $1.2 \mathrm{E}-04$ & 0.24 \\
\hline Ethyl chloride & $1.1 \mathrm{E}-04$ & 0.21 \\
\hline Ethylene dichloride & 1.0E-04 & 0.20 \\
\hline Bromoform & $1.0 \mathrm{E}-05$ & 0.20 \\
\hline Chlorobenzene & $9.0 \mathrm{E}-05$ & 0.18 \\
\hline Methyl tert butyl ether & $8.0 \mathrm{E}-05$ & 0.18 \\
\hline 1,3-Butadiene & $8.5 \mathrm{E}-05$ & 0.17 \\
\hline Fluorene & $8.5 E-05$ & 0.17 \\
\hline Styrene & $6.3 \mathrm{E}-05$ & 0.13 \\
\hline Methyl methacrylate & $5.0 \mathrm{E}-05$ & 0.10 \\
\hline 1,2-Dichloroethane & $5.0 \mathrm{E}-05$ & 0.10 \\
\hline Phenol & $4.0 \mathrm{E}-05$ & 0.081 \\
\hline Dichlorobenzene & $4.0 \mathrm{E}-05$ & 0.080 \\
\hline Carbonyl sulfide & $3.8 \mathrm{E}-05$ & 0.076 \\
\hline Acetophenone & $3.8 \mathrm{E}-05$ & 0.076 \\
\hline Acenaphthene & 3.7E-05 & 0.075 \\
\hline Fluoranthene & $2.9 \mathrm{E}-05$ & 0.058 \\
\hline 1,2-Dichloropropane & $2.6 \mathrm{E}-05$ & 0.052 \\
\hline Acenaphthylene & $2.1 \mathrm{E}-05$ & 0.042 \\
\hline Pyrene & $2.1 \mathrm{E}-05$ & 0.041 \\
\hline Pentachlorophenol & $2.0 \mathrm{E}-05$ & 0.040 \\
\hline Vinyl acetate & $1.9 \mathrm{E}-05$ & 0.038 \\
\hline 2-Chloroacetophenone & $1.8 \mathrm{E}-05$ & 0.035 \\
\hline 1,1,2-Trichloroethane & $1.7 \mathrm{E}-05$ & 0.034 \\
\hline Cumene & $1.3 \mathrm{E}-05$ & 0.027 \\
\hline Benzoanthracene & $9.9 E-06$ & 0.020 \\
\hline Anthracene & $7.5 \mathrm{E}-06$ & 0.015 \\
\hline Chrysene & 5.7E-06 & 0.011 \\
\hline Benzoperylene & 4.7E-06 & 0.0094 \\
\hline Biphenyl & $4.3 \mathrm{E}-06$ & 0.0086 \\
\hline Indeno( $(1,2,3)$ pyrene & $4.3 \mathrm{E}-06$ & 0.0085 \\
\hline Benzofluoranthene & 4.1E-06 & 0.0083 \\
\hline Dibenzanthracene & $3.9 \mathrm{E}-06$ & 0.0077 \\
\hline Ethylene dibromide & $3.3 \mathrm{E}-06$ & 0.0065 \\
\hline Benzopyrene & $7.6 \mathrm{E}-07$ & 0.0015 \\
\hline 2,4-Dinitrotoluene & $7.1 \mathrm{E}-07$ & 0.0014 \\
\hline 5-Methyl chrysene & $5.6 \mathrm{E}-08$ & 0.00011 \\
\hline
\end{tabular}


Table 30. Hazardous metal emissions from the INEEL for 1998.

\begin{tabular}{lcc}
\hline Chemical & ton/yr & lb/yr \\
\hline Lead & $8.0 \mathrm{E}-02$ & 160 \\
Magnesium & $2.8 \mathrm{E}-02$ & 56 \\
Mercury & $2.4 \mathrm{E}-02$ & 48 \\
Chromium & $1.2 \mathrm{E}-02$ & 25 \\
Manganese & $4.3 \mathrm{E}-03$ & 8.5 \\
Nickel & $4.2 \mathrm{E}-03$ & 8.4 \\
Selenium & $4.0 \mathrm{E}-03$ & 7.9 \\
Cadmium & $2.5 \mathrm{E}-03$ & 5.0 \\
Arsenic & $2.2 \mathrm{E}-03$ & 4.3 \\
Beryllium & $7.0 \mathrm{E}-04$ & 1.4 \\
Cobalt & $2.6 \mathrm{E}-04$ & 0.51 \\
Antimony & $2.5 \mathrm{E}-04$ & 0.49 \\
Chromium VI & $2.0 \mathrm{E}-04$ & 0.40 \\
\hline
\end{tabular}

Table 31. Primary pollutant emissions from the INEEL for 1998.

\begin{tabular}{lrr}
\hline Chemical & ton/yr & \multicolumn{1}{c}{$1 \mathrm{~b} / \mathrm{yr}$} \\
\hline Nitrogen oxides & $5.4 \mathrm{E}+02$ & $1,086,613$ \\
Carbon monoxide & $2.8 \mathrm{E}+02$ & 569,708 \\
Sulfur oxides & $1.8 \mathrm{E}+02$ & 362,414 \\
VOC-nonmethane & $5.1 \mathrm{E}+01$ & 101,485 \\
PM-10 & $3.2 \mathrm{E}+01$ & 63,608 \\
\hline
\end{tabular}


Table 32. Alphabetical list of all emissions from the INEEL for 1998.

\begin{tabular}{|c|c|c|}
\hline Chemical & ton/yr & $\mathrm{lb} / \mathrm{yr}$ \\
\hline Acenaphthene & $3.7 \mathrm{E}-05$ & 0.075 \\
\hline Acenaphthylene & $2.1 E-05$ & 0.042 \\
\hline Acetaldehyde & $6.3 \mathrm{E}-03$ & 13 \\
\hline Acetone & $1.0 \mathrm{E}-02$ & 20 \\
\hline Acetophenone & $3.8 \mathrm{E}-05$ & 0.076 \\
\hline Acrolein & $1.1 \mathrm{E}-03$ & 2.2 \\
\hline Acrylonitrile & 4.3E-04 & 0.86 \\
\hline Anthracene & $7.5 \mathrm{E}-06$ & 0.015 \\
\hline Antimony & $2.5 \mathrm{E}-04$ & 0.49 \\
\hline Arsenic & $2.2 \mathrm{E}-03$ & 4.3 \\
\hline Barium & $2.0 \mathrm{E}-04$ & 0.40 \\
\hline Benzene & $2.9 \mathrm{E}-02$ & 59 \\
\hline Benzoanthracene & $9.9 \mathrm{E}-06$ & 0.020 \\
\hline Benzofluoranthene & 4.1E-06 & 0.0083 \\
\hline Benzoperylene & $4.7 \mathrm{E}-06$ & 0.0094 \\
\hline Benzopyrene & $7.6 \mathrm{E}-07$ & 0.0015 \\
\hline Benzyl chloride & $1.8 \mathrm{E}-03$ & 3.5 \\
\hline Beryllium & $7.0 \mathrm{E}-04$ & 1.4 \\
\hline Biphenyl & 4.3E-06 & 0.0086 \\
\hline Bis(2-ethylhexyl)phthalate (DEHP) & $1.8 \mathrm{E}-04$ & 0.37 \\
\hline Bromine & $1.3 \mathrm{E}-04$ & 0.26 \\
\hline Bromochloromethane & $6.5 \mathrm{E}-04$ & 1.3 \\
\hline Bromoform & $1.1 \mathrm{E}-05$ & 0.20 \\
\hline 1,3-Butadiene & $8.6 \mathrm{E}-05$ & 0.17 \\
\hline Cadmium & $2.5 \mathrm{E}-03$ & 5.0 \\
\hline Carbon disulfide & $5.5 \mathrm{E}-04$ & 1.1 \\
\hline Carbon monoxide & $2.8 \mathrm{E}+02$ & 569,708 \\
\hline Carbon tetrachloride & $2.7 \mathrm{E}+00$ & 5,400 \\
\hline Carbonyl sulfide & $3.8 \mathrm{E}-05$ & 0.076 \\
\hline Chloride & $1.1 \mathrm{E}-03$ & 2.2 \\
\hline 2-Chloroacetophenone & $1.8 \mathrm{E}-05$ & 0.035 \\
\hline Chlorobenzene & $9.2 \mathrm{E}-05$ & 0.18 \\
\hline Chloroethane & $1.9 \mathrm{E}-04$ & 0.38 \\
\hline Chloroform & $1.0 \mathrm{E}-01$ & 200 \\
\hline Chromium & $1.2 \mathrm{E}-02$ & 25 \\
\hline Chromium vi & $2.0 \mathrm{E}-04$ & 0.40 \\
\hline Chrysene & $5.7 \mathrm{E}-06$ & 0.011 \\
\hline Cobalt & $2.5 \mathrm{E}-04$ & 0.51 \\
\hline Cumene & $1.3 \mathrm{E}-05$ & 0.027 \\
\hline Cumene hydroperoxide & $1.4 \mathrm{E}-04$ & 0.28 \\
\hline
\end{tabular}


Table 32. (continued)

\begin{tabular}{|c|c|c|}
\hline Chemical & $\operatorname{ton} / \mathrm{yr}$ & $1 \mathrm{~b} / \mathrm{yr}$ \\
\hline Cyanide & $6.5 \mathrm{E}-03$ & 13 \\
\hline Dibenzanthracene & $3.9 \mathrm{E}-06$ & 0.0077 \\
\hline Dichlorobenzene & $4.0 \mathrm{E}-05$ & 0.080 \\
\hline 1,1-Dichloroethane & $3.8 \mathrm{E}-04$ & 0.75 \\
\hline 1,2-Dichloroethane & 5.0E-05 & 0.10 \\
\hline Dichloromethane & $1.6 \mathrm{E}-03$ & 3.2 \\
\hline 1,2-Dichloropropane & $2.6 \mathrm{E}-05$ & 0.052 \\
\hline Diethanolamine & $2.0 \mathrm{E}-04$ & 0.40 \\
\hline Diethyl phthalate & $1.4 \mathrm{E}-04$ & 0.28 \\
\hline Dimethyl sulfate & $1.2 \mathrm{E}-04$ & 0.24 \\
\hline 2,4-Dinitrotoluene & $7.1 \mathrm{E}-07$ & 0.0014 \\
\hline Ethyl benzene & $9.7 \mathrm{E}-04$ & 1.9 \\
\hline Ethyl chloride & 1.1E-04 & 0.21 \\
\hline Ethylene dibromide & $3.3 \mathrm{E}-06$ & 0.0065 \\
\hline Ethylene dichloride & $1.0 \mathrm{E}-04$ & 0.20 \\
\hline Fluoranthene & $2.9 \mathrm{E}-05$ & 0.058 \\
\hline Fluorene & $8.5 E-05$ & 0.17 \\
\hline Fluorides & $2.4 \mathrm{E}-03$ & 4.8 \\
\hline Formaldehyde & $9.9 \mathrm{E}-02$ & 197 \\
\hline Hexane & $2.3 \mathrm{E}-02$ & 46 \\
\hline Hydrochloric acid & $2.0 \mathrm{E}+00$ & 4,000 \\
\hline Hydrofluoric acid & $1.0 \mathrm{E}-02$ & 20 \\
\hline Indeno $(1,2,3)$ pyrene & 4.3E-06 & 0.0085 \\
\hline Iodine & $2.0 \mathrm{E}-04$ & 0.40 \\
\hline Iron oxide fume & $2.0 \mathrm{E}-04$ & 0.40 \\
\hline Isophorone & $1.5 \mathrm{E}-03$ & 2.9 \\
\hline Lead & $8.0 \mathrm{E}-02$ & 160 \\
\hline Magnesium & $2.8 \mathrm{E}-02$ & 56 \\
\hline Manganese & $4.3 \mathrm{E}-03$ & 8.5 \\
\hline Mercury & $2.4 \mathrm{E}-02$ & 48 \\
\hline Methyl alcohol & $7.0 \mathrm{E}-02$ & 140 \\
\hline Methyl bromide & 4.0E-04 & 0.81 \\
\hline Methyl chloride & $1.3 \mathrm{E}-03$ & 2.7 \\
\hline 5-Methyl chrysene & $5.6 \mathrm{E}-08$ & 0.00011 \\
\hline Methyl hydrazine & 4.3E-04 & 0.86 \\
\hline Methyl isobutyl ketone & $2.4 \mathrm{E}-04$ & 0.48 \\
\hline Methyl methacrylate & $5.1 \mathrm{E}-05$ & 0.10 \\
\hline Methyl tert butyl ether & $8.8 \mathrm{E}-05$ & 0.18 \\
\hline
\end{tabular}


Table 32. (continued)

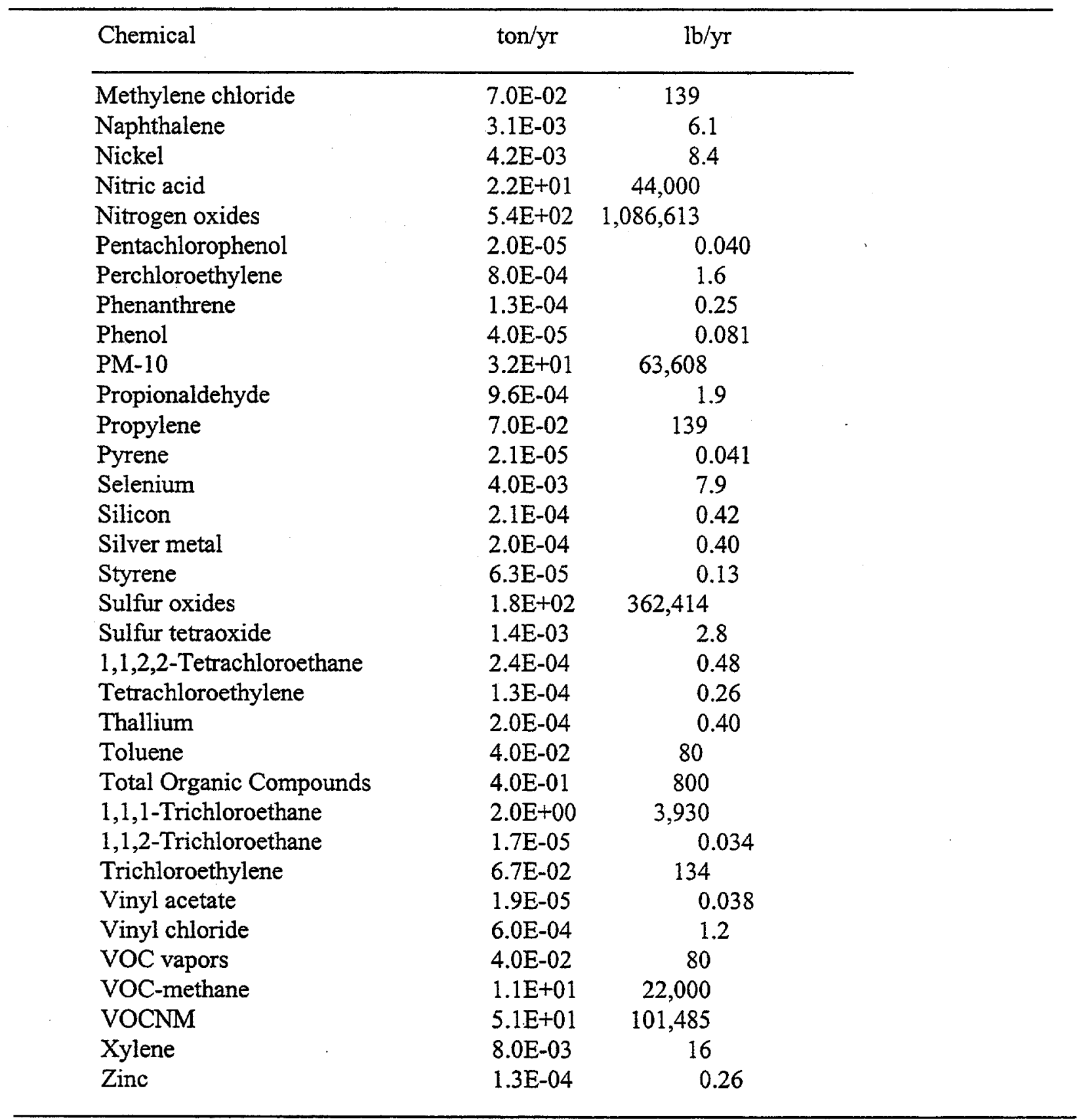


Table 33. Summary of principle pollutant emissions from the INEEL for 1998.

\begin{tabular}{|c|c|c|c|c|c|}
\hline \multirow[b]{2}{*}{ Pollutant } & \multirow[b]{2}{*}{ Area } & \multicolumn{2}{|c|}{ Emissions } & \multicolumn{2}{|c|}{ Descending rank } \\
\hline & & $\mathrm{lb} / \mathrm{hr}^{*}$ & $\operatorname{ton} / \mathrm{yr}$ & Area & $\mathrm{lb} / \mathrm{yr}$ \\
\hline \multirow[t]{8}{*}{$\mathrm{CO}$} & ANL & $1.0 \mathrm{E}+01$ & $1.8 \mathrm{E}+00$ & CPP & 440,000 \\
\hline & CFA & 2.2E-01 & $4.6 \mathrm{E}-01$ & TRA & 36,000 \\
\hline & $\mathrm{CPP}$ & $2.9 \mathrm{E}+02$ & $2.2 \mathrm{E}+02$ & ANL & 3,600 \\
\hline & NRF & $4.4 \mathrm{E}+01$ & $1.7 \mathrm{E}+00$ & NRF & 3,400 \\
\hline & PER & $1.3 \mathrm{E}-01$ & $1.1 \mathrm{E}-01$ & WMF & 2,000 \\
\hline & TAN & $2.0 \mathrm{E}+00$ & $6.0 \mathrm{E}-01$ & TAN & 1,200 \\
\hline & TRA & $1.7 \mathrm{E}+01$ & $1.8 \mathrm{E}+01$ & CFA & 920 \\
\hline & WMF & $2.0 \mathrm{E}+00$ & $1.0 \mathrm{E}+00$ & PER & 220 \\
\hline \multirow[t]{8}{*}{ NOx } & ANL & $4.4 \mathrm{E}+01$ & $7.3 \mathrm{E}+00$ & CPP & 780,000 \\
\hline & CFA & $7.2 \mathrm{E}-01$ & $3.1 \mathrm{E}+00$ & TRA & 142,000 \\
\hline & $\mathrm{CPP}$ & $3.9 \mathrm{E}+02$ & $3.9 \mathrm{E}+02$ & WMF & 30,000 \\
\hline & NRF & $1.8 \mathrm{E}+02$ & $6.5 E+00$ & ANL & 14,600 \\
\hline & PER & $1.4 \mathrm{E}+00$ & $1.9 E+00$ & NRF & 13,000 \\
\hline & TAN & $8.2 \mathrm{E}+00$ & $5.6 \mathrm{E}+00$ & TAN & 11,200 \\
\hline & TRA & $6.5 E+01$ & $7.1 \mathrm{E}+01$ & CFA & 6,200 \\
\hline & WMF & $7.7 \mathrm{E}+00$ & $1.5 \mathrm{E}+01$ & PER & 3,800 \\
\hline \multirow[t]{8}{*}{ PM-10 } & ANL & $2.5 \mathrm{E}+00$ & $3.7 \mathrm{E}-01$ & CFA & 84,000 \\
\hline & CFA & $4.1 E+01$ & $4.2 E+01$ & TRA & 8,000 \\
\hline & CPP & $2.2 \mathrm{E}+00$ & $1.7 \mathrm{E}+00$ & CPP & 3,400 \\
\hline & NRF & $4.3 E+00$ & $6.3 \mathrm{E}-01$ & WMF & 2,400 \\
\hline & PER & $4.4 \mathrm{E}-02$ & $6.4 \mathrm{E}-02$ & TAN & 1,580 \\
\hline & TAN & $6.3 \mathrm{E}-01$ & $7.9 \mathrm{E}-01$ & NRF & 1,260 \\
\hline & TRA & $2.1 E+00$ & $4.0 \mathrm{E}+00$ & ANL & 740 \\
\hline & WMF & $4.0 \mathrm{E}-01$ & $1.2 \mathrm{E}+00$ & PER & 128 \\
\hline \multirow[t]{8}{*}{ SOx } & ANL & $8.1 \mathrm{E}+01$ & $5.0 \mathrm{E}+01$ & CPP & 154,000 \\
\hline & CFA & $5.1 E+00$ & $1.3 E+01$ & ANL & 100,000 \\
\hline & $\mathrm{CPP}$ & $1.4 \mathrm{E}+02$ & $7.7 E+01$ & TAN & 34,000 \\
\hline & NRF & $3.6 \mathrm{E}+00$ & $5.4 \mathrm{E}+00$ & CFA & 26,000 \\
\hline & PER & $3.3 \mathrm{E}+00$ & $2.8 \mathrm{E}+00$ & TRA & 22,000 \\
\hline & TAN & $5.6 \mathrm{E}+01$ & $1.7 \mathrm{E}+01$ & NRF & 10,800 \\
\hline & TRA & $1.0 \mathrm{E}+01$ & $1.1 \mathrm{E}+01$ & WMF & 6,000 \\
\hline & WMF & $1.5 E+00$ & $3.0 \mathrm{E}+00$ & PER & 5,600 \\
\hline
\end{tabular}

* Hourly rates are only an approximation and assume that rates are additive. These rates may be skewed upward.. 
Table 33. (continued)

\begin{tabular}{|c|c|c|c|c|c|}
\hline \multirow[b]{2}{*}{ Pollutant } & \multirow[b]{2}{*}{ Area } & \multicolumn{2}{|c|}{ Emissions } & \multicolumn{2}{|c|}{ Descending rank } \\
\hline & & $\mathrm{lb} / \mathrm{hr}^{*}$ & ton/yr & Area & $\mathrm{lb} / \mathrm{yr}$ \\
\hline \multirow[t]{8}{*}{ VOCNM } & ANL & $2.5 \mathrm{E}+01$ & $2.0 \mathrm{E}+00$ & CPP & 28,000 \\
\hline & $\mathrm{CFA}$ & $7.2 \mathrm{E}-02$ & $1.6 \mathrm{E}+00$ & WMF & 10,800 \\
\hline & CPP & $1.0 \mathrm{E}+01$ & $1.4 \mathrm{E}+01$ & TAN & 8,000 \\
\hline & NRF & $2.3 E+00$ & $8.3 E-01$ & TRA & 6,000 \\
\hline & PER & $6.0 \mathrm{E}-03$ & $2.6 \mathrm{E}-02$ & ANL & 4,000 \\
\hline & TAN & $4.2 \mathrm{E}+01$ & $4.0 E+00$ & CFA & 3,200 \\
\hline & TRA & $1.6 \mathrm{E}+00$ & $3.0 E+00$ & NRF & 1,660 \\
\hline & WMF & $2.1 E+02$ & $5.4 \mathrm{E}+00$ & PER & 52 \\
\hline
\end{tabular}

* Hourly rates are only an approximation and assume that rates are additive. These rates may be skewed upward. 
Table 34. Summary of each principle pollutant by area for 1998 .

\begin{tabular}{|c|c|c|c|c|c|}
\hline \multirow[b]{2}{*}{ Area } & \multirow[b]{2}{*}{ Pollutant } & \multicolumn{2}{|c|}{ Emissions } & \multicolumn{2}{|c|}{ Descending rank } \\
\hline & & $\mathrm{lb} / \mathrm{hr}^{*}$ & ton/yr & Pollutant & $\mathrm{lb} / \mathrm{yr}$ \\
\hline \multirow[t]{5}{*}{ ANL } & Carbon monoxide & $1.0 \mathrm{E}+01$ & $1.8 \mathrm{E}+00$ & SOx & 100,000 \\
\hline & Nitrogen oxides & $4.4 \mathrm{E}+01$ & $7.3 E+00$ & NOx & 14,600 \\
\hline & PM-10 & $2.5 \mathrm{E}+00$ & $3.7 \mathrm{E}-01$ & VOCNM & 4,000 \\
\hline & Sulfur oxides & $8.1 E+01$ & $5.0 \mathrm{E}+01$ & $\mathrm{CO}$ & 3,600 \\
\hline & VOC-nonmethane & $2.5 E+01$ & $2.0 \mathrm{E}+00$ & PM-10 & 740 \\
\hline \multirow[t]{5}{*}{ CFA } & Carbon monoxide & $2.2 \mathrm{E}-01$ & $4.6 \mathrm{E}-01$ & PM-10 & 84,000 \\
\hline & Nitrogen oxides & $7.2 \mathrm{E}-01$ & $3.1 E+00$ & $\mathrm{SOx}$ & 26,000 \\
\hline & PM-10 & $4.1 E+01$ & $4.2 E+01$ & $\mathrm{NOx}$ & 6,200 \\
\hline & Sulfur oxides & $5.1 \mathrm{E}+00$ & $1.3 E+01$ & VOCNM & 3,200 \\
\hline & VOC-nonmethane & $7.2 \mathrm{E}-02$ & $1.6 \mathrm{E}+00$ & $\mathrm{CO}$ & 920 \\
\hline \multirow[t]{5}{*}{ CPP } & Carbon monoxide & $2.9 \mathrm{E}+02$ & $2.2 \mathrm{E}+02$ & $\mathrm{NOx}$ & 780,000 \\
\hline & Nitrogen oxides & $3.9 \mathrm{E}+02$ & $3.9 \mathrm{E}+02$ & $\mathrm{CO}$ & 440,000 \\
\hline & PM-10 & $2.2 \mathrm{E}+00$ & $1.7 \mathrm{E}+00$ & SOx & 154,000 \\
\hline & Sulfur oxides & $1.4 \mathrm{E}+02$ & $7.7 \mathrm{E}+01$ & VOCNM & 28,000 \\
\hline & VOC-nonmethane & $1.0 \mathrm{E}+01$ & $1.4 \mathrm{E}+01$ & PM-10 & 3,400 \\
\hline \multirow[t]{5}{*}{ NRF } & Carbon monoxide & $4.4 \mathrm{E}+01$ & $1.7 \mathrm{E}+00$ & NOx & 13,000 \\
\hline & Nitrogen oxides & $1.8 \mathrm{E}+02$ & $6.5 \mathrm{E}+00$ & $\mathrm{SOx}$ & 10,800 \\
\hline & PM-10 & $4.3 E+00$ & $6.3 \mathrm{E}-01$ & $\mathrm{CO}$ & 3,400 \\
\hline & Sulfur oxides & $3.6 \mathrm{E}+00$ & $5.4 \mathrm{E}+00$ & VOCNM & 1,660 \\
\hline & VOC-nonmethane & $2.3 E+00$ & $8.3 \mathrm{E}-01$ & PM-10 & 1,260 \\
\hline \multirow[t]{5}{*}{ PER } & Carbon monoxide & 1.3E-01 & $1.1 \mathrm{E}-01$ & SOx & 5,600 \\
\hline & Nitrogen oxides & $1.4 \mathrm{E}+00$ & $1.9 \mathrm{E}+00$ & $\mathrm{NOx}$ & 3,800 \\
\hline & PM-10 & $4.4 \mathrm{E}-02$ & $6.4 \mathrm{E}-02$ & $\mathrm{CO}$ & 220 \\
\hline & Sulfur oxides & $3.3 \mathrm{E}+00$ & $2.8 \mathrm{E}+00$ & PM-10 & 128 \\
\hline & VOC-nonmethane & $6.0 \mathrm{E}-03$ & $2.6 \mathrm{E}-02$ & VOCNM & 52 \\
\hline \multirow[t]{5}{*}{ TAN } & Carbon monoxide & $2.0 \mathrm{E}+00$ & $6.0 \mathrm{E}-01$ & SOx & 34,000 \\
\hline & Nitrogen oxides & $8.2 \mathrm{E}+00$ & $5.6 \mathrm{E}+00$ & $\mathrm{NOx}$ & 11,200 \\
\hline & PM-10 & $6.3 \mathrm{E}-01$ & 7.9E-01 & VOCNM & 8,000 \\
\hline & Sulfur oxides & $5.6 \mathrm{E}+01$ & $1.7 \mathrm{E}+01$ & NOx & 1,580 \\
\hline & VOC-nonmethane & $4.2 \mathrm{E}+01$ & $4.0 \mathrm{E}+00$ & $\mathrm{CO}$ & 1,200 \\
\hline
\end{tabular}

* Hourly rates are only an approximation and assume that rates are additive. These rates may be skewed upward. 
Table 34. (continued)

\begin{tabular}{lllllr}
\hline & & \multicolumn{2}{c}{ Emissions } & \multicolumn{2}{c}{ Descending rank } \\
Area & Pollutant & $\mathrm{lb} / \mathrm{hr}^{*}$ & ton/yr & Pollutant & lb/yr \\
\hline \multirow{2}{*}{ TRA } & Carbon monoxide & $1.7 \mathrm{E}+01$ & $1.8 \mathrm{E}+01$ & NOx & 142,000 \\
& Nitrogen oxides & $6.5 \mathrm{E}+01$ & $7.1 \mathrm{E}+01$ & $\mathrm{CO}$ & 36,000 \\
& PM-10 & $2.1 \mathrm{E}+00$ & $4.0 \mathrm{E}+00$ & $\mathrm{SOx}$ & 22,000 \\
& Sulfur oxides & $1.0 \mathrm{E}+01$ & $1.1 \mathrm{E}+01$ & PM-10 & 8,000 \\
& VOC-nonmethane & $1.6 \mathrm{E}+00$ & $3.0 \mathrm{E}+00$ & VOCNM & 6,000 \\
& & & & & \\
\hline \multirow{2}{*}{ WMF } & Carbon monoxide & $2.0 \mathrm{E}+00$ & $1.0 \mathrm{E}+00$ & NOx & 30,000 \\
& Nitrogen oxides & $7.7 \mathrm{E}+00$ & $1.5 \mathrm{E}+01$ & VOCNM & 10,800 \\
& PM-10 & $4.0 \mathrm{E}-01$ & $1.2 \mathrm{E}+00$ & SOx & 6,000 \\
& Sulfur oxides & $1.5 \mathrm{E}+00$ & $3.0 \mathrm{E}+00$ & PM-10 & 2,400 \\
& VOC-nonmethane & $2.1 \mathrm{E}+02$ & $5.4 \mathrm{E}+00$ & CO & 2,000 \\
& & & & \\
\hline
\end{tabular}

* Hourly rates are only an approximation and assume that rates are additive. These rates may be skewed upward. 
Table 35. Emissions by area, building and vent for 1998 .

\begin{tabular}{|c|c|c|c|c|c|c|c|}
\hline \multirow[b]{2}{*}{ Area } & \multirow[b]{2}{*}{ Bldg } & \multirow[b]{2}{*}{ Vent } & \multirow[b]{2}{*}{ Pollutant } & \multirow[b]{2}{*}{ Source type } & \multirow{2}{*}{$\begin{array}{l}\text { Calc } \\
\text { method }\end{array}$} & \multicolumn{2}{|c|}{ Emissions } \\
\hline & & & & & & $\mathrm{lb} / \mathrm{hr}$ & $\operatorname{ton} / \mathrm{yr}$ \\
\hline \multirow[t]{39}{*}{ ANL } & \multirow[t]{39}{*}{707} & \multirow[t]{13}{*}{002} & 1,3-Butadiene & Fuel burning equipment & System & 1.1E-04 & $0.0 E+00$ \\
\hline & & & Acetaldehyde & Fuel burning equipment & System & $2.0 \mathrm{E}-03$ & $2.0 \mathrm{E}-05$ \\
\hline & & & Acrolein & Fuel burning equipment & System & $2.6 E-04$ & $0.0 E+00$ \\
\hline & & & Benzene & Fuel burning equipment & System & 2.6E-03 & $3.0 \mathrm{E}-05$ \\
\hline & & & Carbon monoxide & Fuel burning equipment & System & $2.7 E+00$ & 2.9E-02 \\
\hline & & & Formaldehyde & Fuel burning equipment & System & $3.2 E-03$ & 3.0E-05 \\
\hline & & & Nitrogen oxides & Fuel burning equipment & System & $1.2 E+01$ & 1.3E-01 \\
\hline & & & PM-10 & Fuel burning equipment & System & $8.4 \mathrm{E}-01$ & $9.2 \mathrm{E}-03$ \\
\hline & & & Propylene & Fuel burning equipment & System & 7.0E-03 & $8.0 \mathrm{E}-05$ \\
\hline & & & Sulfur oxides & Fuel burning equipment & System & $8.0 E-01$ & 8.7E-03 \\
\hline & & & Toluene & Fuel burning equipment & System & 1.1E-03 & $1.0 \mathrm{E}-05$ \\
\hline & & & VOC-nonmethane & Fuel burning equipment & System & 8.8E-01 & $9.6 E-03$ \\
\hline & & & Xylene & Fuel burning equipment & System & $7.8 \mathrm{E}-04$ & $1.0 \mathrm{E}-05$ \\
\hline & & \multirow[t]{13}{*}{008} & Acetaldehyde & Fuel burning equipment & System & $3.0 E-05$ & $0.0 E+00$ \\
\hline & & & Acrolein & Fuel burning equipment & System & 1.0E-05 & $0.0 \mathrm{E}+00$ \\
\hline & & & Benzene & Fuel burning equipment & System & $9.9 E-04$ & $2.0 E-05$ \\
\hline & & & Carbon monoxide & Fuel burning equipment & System & $1.0 E+00$ & $1.8 \mathrm{E}-02$ \\
\hline & & & Formaldehyde & Fuel burning equipment & System & 1.0E-04 & $0.0 \mathrm{E}+00$ \\
\hline & & & Nitrogen oxides & Fuel burning equipment & System & $3.9 E+00$ & $6.9 E-02$ \\
\hline & & & $P M-10$ & Fuel burning equipment & System & $7.2 E-02$ & $1.3 E-03$ \\
\hline & & & Propylene & Fuel burning equipment & System & $3.4 \mathrm{E}-03$ & $6.0 \mathrm{E}-05$ \\
\hline & & & Sulfur oxides & Fuel burning equipment & System & $6.2 E-01$ & 1.1E-02 \\
\hline & & & Toluene & Fuel burning equipment & System & $3.4 E-04$ & $1.0 \mathrm{E}-05$ \\
\hline & & & VOC-methane & Fuel burning equipment & System & $9.9 E-03$ & 1.7E-04 \\
\hline & & & VOC-nonmethane & Fuel burning equipment & System & $9.9 E-02$ & $1.7 E-03$ \\
\hline & & & Xylene & Fuel burning equipment & System & 2.3E-04 & $0.0 E+00$ \\
\hline & & \multirow[t]{13}{*}{016} & Acetaldehyde & Fuel burning equipment & System & $3.0 \mathrm{E}-05$ & $0.0 E+00$ \\
\hline & & & Acrolein & Fuel burning equipment & System & $1.0 \mathrm{E}-05$ & $0.0 E+00$ \\
\hline & & & Benzene & Fuel burning equipment & System & $9.9 E-04$ & $1.0 \mathrm{E}-05$ \\
\hline & & & Carbon monoxide & Fuel burning equipment & System & $1.0 E+00$ & 1.0E-02 \\
\hline & & & Formaldehyde & Fuel burning equipment & System & 1.0E-04 & $0.0 E+00$ \\
\hline & & & Nitrogen oxides & Fuel burning equipment & System & $3.9 E+00$ & $3.9 E-02$ \\
\hline & & & PM-10 & Fuel buming equipment & System & $7.2 E-02$ & 7.0E-04 \\
\hline & & & Propylene & Fuel burning equipment & System & $3.4 E-03$ & $3.0 \mathrm{E}-05$ \\
\hline & & & Sulfur oxides & Fuel burning equipment & System & $6.2 E-01$ & $6.1 E-03$ \\
\hline & & & Toluene & Fuel burning equipment & System & $3.4 E-04$ & $0.0 \mathrm{E}+00$ \\
\hline & & & VOC-methane & Fuel burning equipment & System & $9.9 \mathrm{E}-03$ & $1.0 E-04$ \\
\hline & & & VOC-nonmethane & Fuel burning equipment & System & $9.9 E-02$ & $9.7 E-04$ \\
\hline & & & Xylene & Fuel burning equipment & System & 2.3E-04 & $0.0 E+00$ \\
\hline \multirow[t]{11}{*}{ ANL } & \multirow[t]{11}{*}{$752 \mathrm{~A}$} & \multirow[t]{11}{*}{001} & 1,3-Butadiene & Fuel burning equipment & System & 7.0E-05 & $0.0 E+00$ \\
\hline & & & Acetaldehyde & Fuel burning equipment & System & 1.3E-03 & 1.0E-05 \\
\hline & & & Acrolein & Fuel burning equipment & System & $1.7 E-04$ & $0.0 E+00$ \\
\hline & & & Benzene & Fuel burning equipment & System & 1.7E-03 & $1.0 E-05$ \\
\hline & & & Carbon monoxide & Fuel burning equipment & System & $1.7 E+00$ & $8.8 E-03$ \\
\hline & & & Formaldehyde & Fuel burning equipment & System & 2.1E-03 & $1.0 \mathrm{E}-05$ \\
\hline & & & Nitrogen oxides & Fuel burning equipment & System & $7.9 E+00$ & $4.0 E-02$ \\
\hline & & & $P M-10$ & Fuel burning equipment & System & 5.5E-01 & 2.7E-03 \\
\hline & & & Propylene & Fuel burning equipment & System & 4.6E-03 & 2.0E-05 \\
\hline & & & Sulfur oxides & Fuel burning equipment & System & 5.2E-01 & 2.6E-03 \\
\hline & & & Toluene & Fuel burning equipment & System & 7.3E-04 & $0.0 E+00$ \\
\hline
\end{tabular}

* Not significant source 
Table 35. (continued)

\begin{tabular}{|c|c|c|c|c|c|c|c|}
\hline \multirow[b]{2}{*}{ Area } & \multirow[b]{2}{*}{ Bldg } & \multirow[b]{2}{*}{ Vent } & \multirow[b]{2}{*}{ Pollutant } & \multirow[b]{2}{*}{ Source type } & \multirow{2}{*}{$\begin{array}{c}\text { Calc } \\
\text { method }\end{array}$} & \multicolumn{2}{|c|}{ Emissions } \\
\hline & & & & & & $\mathrm{lb} / \mathrm{hr}$ & ton/yr \\
\hline \multirow[t]{42}{*}{ ANL } & \multirow[t]{2}{*}{$752 A$} & \multirow[t]{2}{*}{001} & VOC-nonmethane & Fuel burning equipment & System & 5.7E-01 & $2.9 E-03$ \\
\hline & & & Xylene & Fuel burning equipment & System & 5.1E-04 & $0.0 \mathrm{E}+00$ \\
\hline & \multirow[t]{2}{*}{753} & \multirow[t]{2}{*}{029} & PM-10 & Chemical source & Manually & $1.2 \mathrm{E}-03$ & $0.0 \mathrm{E}+00$ \\
\hline & & & VOC-nonmethane & Chemical source & Manually & $5.0 \mathrm{E}-02$ & 3.0E-05 \\
\hline & $755 A$ & 001 & VOC-nonmethane & Storage tank - VOC & System & $1.1 E+01$ & $1.4 E+00$ \\
\hline & $755 B$ & 002 & VOC-nonmethane & Storage tank - VOC & System & $1.1 E+01$ & 5.0E-01 \\
\hline & \multirow[t]{36}{*}{768} & \multirow[t]{12}{*}{022} & 1,1,1-Trichloroethane & Fuel burning equipment & System & $3.0 \mathrm{E}-05$ & $1.0 \mathrm{E}-05$ \\
\hline & & & Benzene & Fuel burning equipment & System & $3.0 \mathrm{E}-05$ & $1.0 \mathrm{E}-05$ \\
\hline & & & Carbon monoxide & Fuel burning equipment & System & $6.5 E-01$ & $2.1 E-01$ \\
\hline & & & Formaldehyde & Fuel buming equipment & System & 4.3E-03 & 1.4E-03 \\
\hline & & & Naphthalene & Fuel burning equipment & System & $1.5 E-04$ & $5.0 \mathrm{E}-05$ \\
\hline & & & Nitrogen oxides & Fuel burning equipment & System & $2.6 E+00$ & $8.4 E-01$ \\
\hline & & & Xylenes & Fuel burning equipment & System & $1.0 E-05$ & $0.0 E+00$ \\
\hline & & & $P M-10$ & Fuel burning equipment & System & $1.3 E-01$ & $4.2 E-02$ \\
\hline & & & Sulfur oxides & Fuel burning equipment & System & $1.9 E+01$ & $6.1 E+00$ \\
\hline & & & Toluene & Fuel burning equipment & System & 8.1E-04 & $2.6 E-04$ \\
\hline & & & VOC-methane & Fuel burning equipment & System & $6.8 E-03$ & 2.2E-03 \\
\hline & & & VOC-nonmethane & Fuel buming equipment & System & $2.6 E-02$ & 8.4E-03 \\
\hline & & \multirow[t]{12}{*}{024} & 1,1,1-Trichloroethane & Fuel burning equipment & System & $3.0 \mathrm{E}-05$ & $3.0 \mathrm{E}-05$ \\
\hline & & & Benzene & Fuel burning equipment & System & 3.0E-05 & 3.0E-05 \\
\hline & & & Carbon monoxide & Fuel burning equipment & System & $6.5 \mathrm{E}-01$ & $6.0 \mathrm{E}-01$ \\
\hline & & & Formaldehyde & Fuel burning equipment & System & 4.3E-03 & 4.0E-03 \\
\hline & & & Naphthalene & Fuel burning equipment & System & $1.5 E-04$ & $1.4 E-04$ \\
\hline & & & Nitrogen oxides & Fuel burning equipment & System & 2.6E+00 & $2.4 E+00$ \\
\hline & & & Xylenes & Fuel buming equipment & System & $1.0 \mathrm{E}-05$ & $1.0 E-05$ \\
\hline & & & PM-10 & Fuel buming equipment & System & $1.3 E-01$ & $1.2 \mathrm{E}-01$ \\
\hline & & & Sulfur oxides & Fuel burning equipment & System & $1.9 E+01$ & 1.7E $\div 01$ \\
\hline & & & Toluene & Fuel burning equipment & System & 8.1E-04 & 7.4E-04 \\
\hline & & & VOC-methane & Fuel burning equipment & System & $6.8 E-03$ & $6.2 \mathrm{E}-03$ \\
\hline & & & VOC-nonmethane & Fuel burning equipment & System & $2.6 E-02$ & 2.4E-02 \\
\hline & & \multirow[t]{12}{*}{027} & 1,1,1-Trichloroethane & Fuel burning equipment & System & $3.0 \mathrm{E}-05$ & $0.0 E+\infty 0$ \\
\hline & & & Benzene & Fuel burning equipment & System & $3.0 \mathrm{E}-05$ & $0.0 E+00$ \\
\hline & & & Carbon monoxide & Fuel burning equipment & System & 6.7E-01 & 4.9E-03 \\
\hline & & & Formaldehyde & Fuel burning equipment & System & 4.4E-03 & $3.0 E-05$ \\
\hline & & & Naphthalene & Fuel burning equipment & System & $1.5 E-04$ & $0.0 E+00$ \\
\hline & & & Nitrogen oxides & Fuel burning equipment & System & $2.7 E+00$ & 2.0E-02 \\
\hline & & & Xylenes & Fuel burning equipment & System & 1.0E-05 & $0.0 E+00$ \\
\hline & & & $P M-10$ & Fuel buming equipment & System & $1.3 E-01$ & $9.8 \mathrm{E}-04$ \\
\hline & & & Sulfur oxides & Fuel burning equipment & System & $1.9 E+01$ & 1.4E-01 \\
\hline & & & Toluene & Fuel burning equipment & System & $8.3 E-04$ & 1.0E-05 \\
\hline & & & VOC-methane & Fuel burning equipment & System & 7.0E-03 & 5.0E-05 \\
\hline & & & VOC-nonmethane & Fuel burning equipment & System & $2.7 E-02$ & 2.0E-04 \\
\hline \multirow[t]{3}{*}{ ANL } & \multirow[t]{3}{*}{768} & \multirow[t]{3}{*}{028} & 1,3-Butadiene & Fuel burning equipment & System & 5.0E-05 & $0.0 E+00$ \\
\hline & & & Acetaldehyde & Fuel burning equipment & System & $9.0 E-04$ & 2.0E-05 \\
\hline & & & Acrolein & Fuel burning equipment & System & $1.2 E-04$ & $0.0 E+00$ \\
\hline
\end{tabular}

* Not significant sources 
Table 35. (continued)

\begin{tabular}{|c|c|c|c|c|c|c|c|}
\hline \multirow[b]{2}{*}{ Area } & \multirow[b]{2}{*}{ Bldg } & \multirow[b]{2}{*}{ Vent } & \multirow[b]{2}{*}{ Pollutant } & \multirow[b]{2}{*}{ Source type } & \multirow{2}{*}{$\begin{array}{l}\text { Calc } \\
\text { method }\end{array}$} & \multicolumn{2}{|c|}{ Emissions } \\
\hline & & & & & & $\mathrm{lb} / \mathrm{hr}$ & ton $/ \mathrm{yr}$ \\
\hline \multirow[t]{22}{*}{ ANL } & 768 & 028 & Benzene & Fuel burning equipment & System & $1.2 E-03$ & 2.0E-05 \\
\hline & & & Carbon monoxide & Fuel burning equipment & System & $1.2 E+\infty 0$ & 2.3E-02 \\
\hline & & & Formaldehyde & Fuel burning equipment & System & $1.4 E-03$ & 3.0E-05 \\
\hline & & & Nitrogen oxides & Fuel burning equipment & System & $5.4 E+00$ & $1.0 E-01$ \\
\hline & & & PM-10 & Fuel burning equipment & System & $3.8 E-01$ & 7.3E-03 \\
\hline & & & Propylene & Fuel burning equipment & System & $3.2 E-03$ & $6.0 \mathrm{E}-05$ \\
\hline & & & Sulfur oxides & Fuel burning equipment & System & $3.6 E-01$ & $6.9 \mathrm{E}-03$ \\
\hline & & & Toluene & Fuel burning equipment & System & 5.0E-04 & $1.0 \mathrm{E}-05$ \\
\hline & & & VOC-nonmethane & Fuel burning equipment & System & 4.0E-01 & $7.6 \mathrm{E}-03$ \\
\hline & & & Xylene & Fuel burning equipment & System & $3.5 E-04$ & $1.0 \mathrm{E}-05$ \\
\hline & & 034 & 1,1,1-Trichloroethane & Fuel burning equipment & System & 4.0E-05 & 4.0E-05 \\
\hline & & & Benzene & Fuel buming equipment & System & 3.0E-05 & 4.0E-05 \\
\hline & & & Carbon monoxide & Fuel burning equipment & System & 7.5E-01 & $9.1 E-01$ \\
\hline & & & Formaldehyde & Fuel burning equipment & System & 4.9E-03 & $6.0 \mathrm{E}-03$ \\
\hline & & & Naphthalene & Fuel burning equipment & System & 1.7E-04 & 2.0E-04 \\
\hline & & & Nitrogen oxides & Fuel buming equipment & System & $3.0 \mathrm{E}+00$ & $3.6 \mathrm{E}+00$ \\
\hline & & & Xylenes & Fuel burning equipment & System & $2.0 E-05$ & 2.0E-05 \\
\hline & & & $P M-10$ & Fuel burning equipment & System & $1.5 \mathrm{E}-01$ & $1.8 E-01$ \\
\hline & & & Sulfur oxides & Fuel buming equipment & System & $2.2 E+01$ & $2.6 E+01$ \\
\hline & & & Toluene & Fuel burning equipment & System & $9.3 E-04$ & $1.1 E-03$ \\
\hline & & & VOC-methane & Fuel burning equipment & System & $7.8 E-03$ & $9.4 E-03$ \\
\hline & & & VOC-nonmethane & Fuel burning equipment & System & $3.0 E-02$ & $3.6 \mathrm{E}-02$ \\
\hline \multirow[t]{15}{*}{ CFA } & 104 & 001 & Acetone & & Manuaily & 1.1E-04 & 5.0E-04 \\
\hline & & & Benzene & & Manually & $2.5 E-04$ & $1.1 \mathrm{E}-03$ \\
\hline & & & $\begin{array}{l}\text { Bromochloromethane, } \\
\text { see } \\
\text { chlorobromomethane }\end{array}$ & & Manually & $1.5 \mathrm{E}-04$ & $6.5 \mathrm{E}-04$ \\
\hline & & & Carbon monoxide & & Manually & $1.2 \mathrm{E}-03$ & 5.1E-03 \\
\hline & & & Ethyl benzene & & Manually & $1.5 E-04$ & $6.5 E-04$ \\
\hline & & & Hexane & & Manually & 1.7E-04 & $7.5 \mathrm{E}-04$ \\
\hline & & & Methyl ethyl ketone & & Manually & 1.5E-04 & $6.5 E-04$ \\
\hline & & & $\begin{array}{l}\text { Perchloroethylene, } \\
\text { Tetrachloroethylene }\end{array}$ & & Manually & $1.8 E-04$ & $8.0 E-04$ \\
\hline & & & PM-10 & & Manually & $3.8 E+01$ & $3.8 E+01$ \\
\hline & & & Toluene & & Manually & 4.4E-03 & $1.9 E-02$ \\
\hline & & & Vinyl chloride & & Manually & $1.4 E-04$ & 6.0E-04 \\
\hline & & & VOC vapors & & Manually & 8.9E-03 & 3.9E-02 \\
\hline & & & VOC-methane & & Manually & $2.3 E+00$ & $1.0 E+01$ \\
\hline & & & VOC-nonmethane & & Manually & $6.1 E-02$ & 2.7E-01 \\
\hline & & & Xylene & & Manually & 3.8E-04 & 1.7E-03 \\
\hline \multirow[t]{6}{*}{ CFA } & 608 & 001 & Carbon monoxide & Fuel buming equipment & Manually & 4.6E-02 & 1.5E-02 \\
\hline & & & Nitrogen oxides & Fuel burning equipment & Manually & $1.8 E-02$ & 6.0E-02 \\
\hline & & & PM-10 & Fuel burning equipment & Manually & $9.9 E-04$ & 3.3E-03 \\
\hline & & & Sulfur oxides & Fuel burning equipment & Manually & $6.5 E-02$ & 2.1E-01 \\
\hline & & & VOC-nonmethane & Fuel burning equipment & Manually & $3.1 E-04$ & $1.0 \mathrm{E}-03$ \\
\hline & 609 & 005 & 1,1,1-Trichloroethane & Fuel burning equipment & System & $0.0 E+00$ & $0.0 E+00$ \\
\hline
\end{tabular}

* Not significant source 
Table 35. (continued)

\begin{tabular}{|c|c|c|c|c|c|c|c|}
\hline \multirow[b]{2}{*}{ Area } & \multirow[b]{2}{*}{ Bldg } & \multirow[b]{2}{*}{ Vent } & \multirow[b]{2}{*}{ Pollutant } & \multirow[b]{2}{*}{ Source type } & \multirow{2}{*}{$\begin{array}{l}\text { Calc } \\
\text { method }\end{array}$} & \multicolumn{2}{|c|}{ Emissions } \\
\hline & & & & & & Ib/hr & $\operatorname{ton} / \mathrm{yr}$ \\
\hline \multirow[t]{36}{*}{ CFA } & \multirow[t]{11}{*}{609} & \multirow[t]{11}{*}{005} & Benzene & Fuel burning equipment & System & $0.0 E+00$ & $0.0 E+00$ \\
\hline & & & Carbon monoxide & Fuel burning equipment & System & $1.0 \mathrm{E}-02$ & $3.6 E-02$ \\
\hline & & & Formaldehyde & Fuel burning equipment & System & 7.0E-05 & 2.3E-04 \\
\hline & & & Naphthalene & Fuel burning equipment & System & $0.0 \mathrm{E}+00$ & 1.0E-05 \\
\hline & & & Nitrogen oxides & Fuel burning equipment & System & $4.0 \mathrm{E}-02$ & 1.4E-01 \\
\hline & & & Xylenes & Fuel burning equipment & System & $0.0 E+00$ & $0.0 E+00$ \\
\hline & & & $P M-10$ & Fuel burning equipment & System & 2.0E-03 & 7.1E-03 \\
\hline & & & Sulfur oxides & Fuel burning equipment & System & 2.9E-01 & $1.0 E+00$ \\
\hline & & & Toluene & Fuel burning equipment & System & $1.0 \mathrm{E}-05$ & 4.0E-05 \\
\hline & & & VOC-methane & Fuel burning equipment & System & 4.3E-04 & $1.5 \mathrm{E}-03$ \\
\hline & & & VOC-nonmethane & Fuel burning equipment & System & $6.8 E-04$ & $2.4 \mathrm{E}-03$ \\
\hline & 623 & 007 & $P M-10$ & Chemical source & Manually & $3.0 E+00$ & $3.0 E+00$ \\
\hline & \multirow[t]{12}{*}{650} & \multirow[t]{12}{*}{007} & 1,1,1-Trichloroethane & Fuel burning equipment & System & $0.0 E+00$ & $0.0 \mathrm{E}+00$ \\
\hline & & & Benzene & Fuel burning equipment & System & $0.0 \mathrm{E}+00$ & $0.0 \mathrm{E}+00$ \\
\hline & & & Carbon monoxide & Fuel burning equipment & System & 5.0E-03 & $1.3 E-02$ \\
\hline & & & Formaidehyde & Fuel burning equipment & System & $3.0 E-05$ & $9.0 E-05$ \\
\hline & & & Naphthalene & Fuel burning equipment & System & $0.0 \mathrm{E}+00$ & $0.0 E+00$ \\
\hline & & & Nitrogen oxides & Fuel burning equipment & System & 2.0E-02 & $5.3 E-02$ \\
\hline & & & Xylenes & Fuel burning equipment & System & $0.0 \mathrm{E}+00$ & $0.0 E+00$ \\
\hline & & & PM-10 & Fuel burning equipment & System & $1.0 \mathrm{E}-03$ & 2.7E-03 \\
\hline & & & Sulfur oxjdes & Fuel buming equipment & System & $1.4 E-01$ & $3.8 E-01$ \\
\hline & & & Toluene & Fuel burning equipment & System & $1.0 \mathrm{E}-05$ & 2.0E-0.5 \\
\hline & & & VOC-methane & Fuel burning equipment & System & 2.2E-04 & 5.8E-04 \\
\hline & & & VOC-nonmethane & Fuel buming equipment & System & $3.4 E-04$ & $9.1 E-04$ \\
\hline & \multirow[t]{12}{*}{662} & \multirow[t]{12}{*}{011} & $1,1,1$-Trichloroethane & Fuel burning equipment & System & $0.0 E+00$ & $0.0 E+00$ \\
\hline & & & Benzene & Fuel burning equipment & System & $0.0 E+00$ & $0.0 E+00$ \\
\hline & & & Carbon monoxide & Fuel burning equipment & System & $1.5 \mathrm{E}-02$ & $9.8 E-03$ \\
\hline & & & Formaldehyde & Fuel burning equipment & System & $1.0 \mathrm{E}-04$ & 6.0E-05 \\
\hline & & & Naphthalene & Fuel burning equipment & System & $0.0 E+00$ & $0.0 E+00$ \\
\hline & & & Nitrogen oxides & Fuel burning equipment & System & $6.0 \mathrm{E}-02$ & $3.9 E-02$ \\
\hline & & & Xylenes & Fuel burning equipment & System & $0.0 E+00$ & $0.0 E+00$ \\
\hline & & & PM-10 & Fuel burning equipment & System & $3.0 E-03$ & $2.0 \mathrm{E}-03$ \\
\hline & & & Sulfur oxides & Fuel burning equipment & System & 4.3E-01 & $2.8 E-01$ \\
\hline & & & Toluene & Fuel burning equipment & System & $2.0 \mathrm{E}-05$ & $1.0 \mathrm{E}-05$ \\
\hline & & & VOC-methane & Fuel burning equipment & System & $6.5 E-04$ & $4.2 E-04$ \\
\hline & & & VOC-nonmethane & Fuel burning equipment & System & $1.0 E-03$ & 6.7E-04 \\
\hline \multirow[t]{9}{*}{ CFA } & \multirow[t]{9}{*}{662} & \multirow[t]{9}{*}{027} & 1,1,1-Trichloroethane & Fuel burning equipment & System & $0.0 \mathrm{E}+00$ & $0.0 E+00$ \\
\hline & & & Benzene & Fuel burning equipment & System & $0.0 E+00$ & $0.0 E+00$ \\
\hline & & & Carbon monoxide & Fuel burning equipment & System & $2.5 E-02$ & $9.4 E-02$ \\
\hline & & & Formaldehyde & Fuel burning equipment & System & 1.7E-04 & $6.2 E-04$ \\
\hline & & & Naphthalene & Fuel burning equipment & System & 1.0E-05 & 2.0E-05 \\
\hline & & & Nitrogen oxides & Fuel burning equipment & System & $1.0 \mathrm{E}-01$ & 3.8E-01 \\
\hline & & & Xylenes & Fuel burning equipment & System & $0.0 E+00$ & $0.0 E+00$ \\
\hline & & & $P M-10$ & Fuel burning equipment & System & 5.0E-03 & $1.9 \mathrm{E}-02$ \\
\hline & & & Sulfur oxides & Fuel burning equipment & System & 7.2E-01 & 2.7E+00 \\
\hline
\end{tabular}

* Not significant sources 
Table 35. (continued)

\begin{tabular}{|c|c|c|c|c|c|c|c|}
\hline \multirow[b]{2}{*}{ Area } & \multirow[b]{2}{*}{ Bldg } & \multirow[b]{2}{*}{ Vent } & \multirow[b]{2}{*}{ Pollutant } & \multirow[b]{2}{*}{ Source type } & \multirow{2}{*}{$\begin{array}{c}\text { Calc } \\
\text { method }\end{array}$} & \multicolumn{2}{|c|}{ Emissions } \\
\hline & & & & & & $\mathrm{lb} / \mathrm{hr}$ & $\operatorname{ton} / \mathrm{yr}$ \\
\hline \multirow[t]{26}{*}{ CFA } & 662 & 027 & Toluene & Fuel burning equipment & System & $3.0 \mathrm{E}-05$ & $1.2 E-04$ \\
\hline & & & VOC-methane & Fuel burning equipment & System & 1.1E-03 & 4.1E-03 \\
\hline & & & VOC-nonmethane & Fuel buming equipment & System & 1.7E-03 & $6.4 \mathrm{E}-03$ \\
\hline & 671 & 007 & 1,1,1-Trichloroethane & Fuel burning equipment & System & $0.0 E+00$ & $0.0 E+00$ \\
\hline & & & Benzene & Fuel burning equipment & System & $0.0 \mathrm{E}+00$ & $0.0 E+00$ \\
\hline & & & Carbon monoxide & Fuel burning equipment & System & 4.0E-02 & $5.2 E-02$ \\
\hline & & & Formaldehyde & Fuel burning equipment & System & 2.6E-04 & $3.4 E-04$ \\
\hline & & & Naphthalene & Fuel burning equipment & System & $1.0 E-05$ & 1.0E-05 \\
\hline & & & Nitrogen oxides & Fuel burning equipment & System & $1.6 E-01$ & 2.1E-01 \\
\hline & & & PM-10 & Fuel burning equipment & System & 8.0E-03 & $1.0 \mathrm{E}-02$ \\
\hline & & & Sulfur oxides & Fuel burning equipment & System & $1.2 E+00$ & $1.5 E+00$ \\
\hline & & & Toluene & Fuel burning equipment & System & 5.0E-05 & 6.0 E-0.05 \\
\hline & & & VOC-methane & Fuel burning equipment & System & $1.7 E-03$ & $2.2 \mathrm{E}-03$ \\
\hline & & & VOC-nonmethane & Fuel burning equipment & System & $2.7 E-03$ & $3.5 E-03$ \\
\hline & & 008 & 1,1,1-Trichloroethane & Fuel burning equipment & System & $0.0 E+00$ & $0.0 E+00$ \\
\hline & & & Benzene & Fuel burning equipment & System & $0.0 E+00$ & $0.0 E+00$ \\
\hline & & & Carbon monoxide & Fuel buming equipment & System & $4.0 E-02$ & $7.0 \mathrm{E}-02$ \\
\hline & & & Formaldehyde & Fuel burning equipment & System & $2.6 E-04$ & $4.6 E-04$ \\
\hline & & & Naphthalene & Fuel burning equipment & System & $1.0 E-05$ & 2.0E-05 \\
\hline & & & Nitrogen oxides & Fuel buming equipment & System & 1.6E-01 & $2.8 E-01$ \\
\hline & & & Xylenes & Fuel burning equipment & System & $0.0 \mathrm{E}+00$ & $0.0 \mathrm{E}+00$ \\
\hline & & & $P M-10$ & Fuel burning equipment & System & $8.0 E-03$ & $1.4 E-02$ \\
\hline & & & Sulfur oxides & Fuel burning equipment & System & $1.2 E+00$ & $2.0 E+00$ \\
\hline & & & Toluene & Fuel burning equipment & System & 5.0E-05 & $9.0 E-05$ \\
\hline & & & VOC-methane & Fuel burning equipment & System & 1.7E-03 & 3.0E-03 \\
\hline & & & VOC-nonmethane & Fuel burning equipment & System & 2.7E-03 & 4.8E-03 \\
\hline \multirow[t]{5}{*}{ CFA } & 688 & 043 & 1,1,1-Trichloroethane & Fuel burning equipment & System & $0.0 E+00$ & $0.0 E+00$ \\
\hline & & & Carbon monoxide & Fuel burning equipment & System & 2.0E-02 & $6.0 \mathrm{E}-03$ \\
\hline & & & Formaldehyde & Fuel burning equipment & System & 1.3E-04 & 4.0E-05 \\
\hline & & & Naphthalene & Fuel burning equipment & System & $0.0 E+00$ & $0.0 E+00$ \\
\hline & & & Nitrogen oxides & Fuel burning equipment & System & $8.0 E-02$ & 2.4E-02 \\
\hline \multirow[t]{15}{*}{ CFA } & 688 & 043 & Xylenes & Fuel burning equipment & System & $0.0 E+00$ & $0.0 E+00$ \\
\hline & & & PM-10 & Fuel burning equipment & System & 4.0E-03 & $1.2 E-03$ \\
\hline & & & Sulfur oxides & Fuel burning equipment & System & $5.8 E-01$ & $1.7 E-01$ \\
\hline & & & Toluene & Fuel burning equipment & System & 2.0E-05 & $1.0 E-05$ \\
\hline & & & VOC-methane & Fuel burning equipment & System & $2.1 E-04$ & $6.0 E-05$ \\
\hline & & & VOC-nonmethane & Fuel burning equipment & System & 8.0E-04 & $2.4 E-04$ \\
\hline & 688 & 044 & 1,1,1-Trichloroethane & Fuel burning equipment & System & $0.0 E+00$ & $1.0 E-05$ \\
\hline & & & Benzene & Fuel burning equipment & System & $0.0 E+00$ & $1.0 \mathrm{E}-05$ \\
\hline & & & Carbon monoxide & Fuel burning equipment & System & 2.0E-02 & 1.6E-01 \\
\hline & & & Formaldehyde & Fuel burning equipment & System & $1.3 E-04$ & 1.1E-03 \\
\hline & & & Naphthalene & Fuel burning equipment & System & $0.0 \mathrm{E}+00$ & 4.0E-05 \\
\hline & & & Nitrogen oxides & Fuel burning equipment & System & $8.0 \mathrm{E}-02$ & $6.5 E-01$ \\
\hline & & & PM-10 & Fuel burning equipment & System & $4.0 \mathrm{E}-03$ & 3.3E-02 \\
\hline & & & Sulfur oxides & Fuel burning equipment & System & 5.8E-01 & $4.7 E+00$ \\
\hline & & & Toluene & Fuel burning equipment & System & $2.0 \mathrm{E}-05$ & $2.0 \mathrm{E}-04$ \\
\hline
\end{tabular}

* Not significant sources 
Table 35. (continued)

\begin{tabular}{|c|c|c|c|c|c|c|c|}
\hline \multirow[b]{2}{*}{ Area } & \multirow[b]{2}{*}{ Bldg } & \multirow[b]{2}{*}{ Vent } & \multirow[b]{2}{*}{ Pollutant } & \multirow[b]{2}{*}{ Source type } & \multirow{2}{*}{$\begin{array}{l}\text { Calc } \\
\text { method }\end{array}$} & \multicolumn{2}{|c|}{ Emissions } \\
\hline & & & & & & $\mathrm{lb} / \mathrm{hr}$ & ton/yr \\
\hline & & & VOC-methane & Fuel burning equipment & System & 2.1E-04 & $1.7 E-03$ \\
\hline & & & VOC-nonmethane & Fuel burning equipment & System & 8.0E-04 & $6.5 E-03$ \\
\hline${ }^{*} \mathrm{CFA}$ & GRP & 001 & Acetaldehyde & Fuel burning equipment & Manually & & 1.1E-04 \\
\hline * & & & Benzene & Fuel burning equipment & Manually & & 1.3E-04 \\
\hline * & & & $\mathrm{CO}$ & Fuel burning equipment & Manually & & 2.2E-01 \\
\hline$\star$ & & & Formaldehyde & Fuel burning equipment & Manually & & 1.7E-04 \\
\hline * & & & Nitrogen oxides & Fuel burning equipment & Manually & & $1.3 E+00$ \\
\hline * & & & $P M-10$ & Fuel burning equipment & Manually & & $6.2 E-02$ \\
\hline * & & & Sulfur oxides & Fuel burning equipment & Manually & & $4.5 E-02$ \\
\hline * & & & Toluene & Fuel burning equipment & Manually & & $6.0 E-05$ \\
\hline * & & & $\begin{array}{l}\text { Total Organic } \\
\text { compounds }\end{array}$ & Fuel burning equipment & Manually & & $7.2 E-02$ \\
\hline * & & & Xylene & Fuel burning equipment & Manually & & 4.0E-05 \\
\hline * & & 002 & VOC-nonmethane & Storage tank - VOC & Manualiy & & $1.0 E-01$ \\
\hline * & & 003 & PM-10 & Chemical source & Manually & & 4.9E-01 \\
\hline * & & & VOC-nonmethane & Chemical source & Manually & & $1.2 E+00$ \\
\hline CPP & 025 & 001 & $P M-10$ & Chemical source & Manually & 2.0E-01 & 4.9E-03 \\
\hline$*$ & 1619 & 005 & Cadmium & Chemical source & Manually & & $0.0 E+00$ \\
\hline * & & & Chromium compounds & Chemical source & Manually & & $0.0 E+00$ \\
\hline * & & & Lead compounds & Chemical source & Manually & & $0.0 \mathrm{E}+00$ \\
\hline * & & & Mercury compounds & Chemical source & Manually & & $0.0 \mathrm{E}+00$ \\
\hline \multirow[t]{8}{*}{ * } & & & VOC vapors & Chemical source & Manually & & $0.0 \mathrm{E}+00$ \\
\hline & 606 & 004 & 1,1,1-Trichloroethane & Fuel burning equipment & System & $5.0 \mathrm{E}-05$ & $6.0 \mathrm{E}-05$ \\
\hline & & & Benzene & Fuel burning equipment & System & 4.0E-05 & 5.0E-05 \\
\hline & & & Carbon monoxide & Fuel burning equipment & System & $1.1 E+00$ & $1.2 E+00$ \\
\hline & & & Formaldehyde & Fuel burning equipment & System & $6.9 \mathrm{E}-03$ & $7.8 \mathrm{E}-03$ \\
\hline & & & Naphthalene & Fuel buming equipment & System & 2.4E-04 & 2.7E-04 \\
\hline & & & Nitrogen oxides & Fuel burning equipment & System & $4.2 E+00$ & 4.7E+00 \\
\hline & & & Xylenes & Fuel burning equipment & System & 2.0E-05 & 3.0E-05 \\
\hline \multirow[t]{5}{*}{ CPP } & 606 & 004 & PM-10 & Fuel burning equipment & System & 2.1E-01 & 2.4E-01 \\
\hline & & & Sulfur oxides & Fuel burning equipment & System & $3.0 E+01$ & $3.4 E+01$ \\
\hline & & & Toluene & Fuel burning equipment & System & 1.3E-03 & $1.5 \mathrm{E}-03$ \\
\hline & & & VOC-methane & Fuel burning equipment & System & 1.1E-02 & $1.2 E-02$ \\
\hline & & & VOC-nonmethane & Fuel burning equipment & System & 4.2E-02 & 4.7E-02 \\
\hline \multirow[t]{11}{*}{ CPP } & 606 & 005 & 1,1,1-Trichloroethane & Fuel burning equipment & System & 3.OE-05 & 5.0E-05 \\
\hline & & & Benzene & Fuel burning equipment & System & 3.0E-05 & 5.0E-05 \\
\hline & & & Carbon monoxide & Fuel buming equipment & System & 6.3E-01 & $1.1 E+00$ \\
\hline & & & Formaldehyde & Fuel burning equipment & System & 4.1E-03 & 7.4E-03 \\
\hline & & & Naphthalene & Fuel burning equipment & System & $1.4 \mathrm{E}-04$ & 2.5E-04 \\
\hline & & & Nitrogen oxides & Fuel burning equipment & System & $2.5 E+00$ & $4.5 E+00$ \\
\hline & & & $\begin{array}{l}\text { Xylenes } \\
\text { PM-10 }\end{array}$ & $\begin{array}{l}\text { Fuel burning equipment } \\
\text { Fuel burning equipment }\end{array}$ & $\begin{array}{l}\text { System } \\
\text { System }\end{array}$ & $\begin{array}{l}1.0 E-05 \\
1.3 E-01\end{array}$ & $\begin{array}{l}2.0 E-05 \\
2.2 E-01\end{array}$ \\
\hline & & & Sulfur oxides & Fuel burning equipment & System & $1.8 E+01$ & $3.2 E+01$ \\
\hline & & & Toluene & Fuel burning equipment & System & $7.8 \mathrm{E}-04$ & 1.4E-03 \\
\hline & & & VOC-methane & Fuel burning equipment & System & $6.5 E-03$ & 1.2E-02 \\
\hline & & & VOC-nonmethane & Fuel burning equipment & System & 2.5E-02 & 4.5E-02 \\
\hline
\end{tabular}

* Not significant sources 
Table 35. (continued)

\begin{tabular}{|c|c|c|c|c|c|c|c|}
\hline \multirow[b]{2}{*}{ Area } & \multirow[b]{2}{*}{ Bldg } & \multirow[b]{2}{*}{ Vent } & \multirow[b]{2}{*}{ Pollutant } & \multirow[b]{2}{*}{ Source type } & \multirow{2}{*}{$\begin{array}{l}\text { Calc } \\
\text { method }\end{array}$} & \multicolumn{2}{|c|}{ Emissions } \\
\hline & & & & & & $\mathrm{lb} / \mathrm{hr}$ & ton/yr \\
\hline \multirow[t]{21}{*}{ CPP } & \multirow[t]{5}{*}{606} & \multirow[t]{5}{*}{019} & Carbon monoxide & Fuel burning equipment & Manually & $0.0 E+00$ & $0.0 \mathrm{E}+00$ \\
\hline & & & Nitrogen oxides & Fuel burning equipment & Manually & $0.0 E+00$ & $0.0 E+00$ \\
\hline & & & PM-10 & Fuel burning equipment & Manually & $0.0 E+00$ & $0.0 \mathrm{E}+00$ \\
\hline & & & Sulfur oxides & Fuel burning equipment & Manually & $0.0 \mathrm{E}+00$ & $0.0 E+00$ \\
\hline & & & VOC-nonmethane & Fuel burning equipment & Manually & $0.0 E+00$ & $0.0 \mathrm{E}+00$ \\
\hline & \multirow[t]{16}{*}{637} & \multirow[t]{8}{*}{032} & Chloride & Chemical source & Manualiy & $3.9 E-03$ & $3.3 E-04$ \\
\hline & & & $\mathrm{CO}$ & Chemical source & Manually. & $2.0 \mathrm{E}+00$ & $3.5 E-01$ \\
\hline & & & Fluorides & Chemical source & Manually & 8.7E-03 & 7.1E-04 \\
\hline & & & Nitrogen oxides & Chemical source & Manually & $2.3 E+00$ & 2.0E-01 \\
\hline & & & $P M-10$ & Chemical source & Manually & $0.0 E+00$ & $0.0 E \div 00$ \\
\hline & & & Sulfur oxides & Chemical source & Manually & 2.6E-03 & $6.5 E-04$ \\
\hline & & & Sulfur tetraoxide & Chemical source & Manually & 5.0E-03 & 4.2E-04 \\
\hline & & & VOC vapors & Chemical source & Manually & $3.2 E-03$ & $6.8 E-04$ \\
\hline & & \multirow[t]{8}{*}{058} & Chloride & & Manually & $1.6 \mathrm{E}-02$ & 8.0E-04 \\
\hline & & & $\mathrm{Co}$ & & Manually & 4.7E+00 & $2.4 E-01$ \\
\hline & & & Fluorides & & Manually & $3.5 E-02$ & 1.7E-03 \\
\hline & & & Nitrogen oxides & & Manually & $9.4 E+00$ & $4.8 \mathrm{E}-01$ \\
\hline & & & PM-10 & & Manually & $0.0 E+00$ & $0.0 E \div 00$ \\
\hline & & & Sulfur oxides & & Manually & 5.8E-03 & 2.9E-04 \\
\hline & & & Sulfur tetraoxide & & Manually & $2.0 E-02$ & 1.0E-03 \\
\hline & & & VOC-nonmethane & & Manually & 2.OE-03 & $1.0 \mathrm{E}-04$ \\
\hline * & 653 & 001 & PM-10 & Chemical source & Manually & $2.8 E-01$ & 1.5E-01 \\
\hline * & \multirow[t]{2}{*}{663} & 130 & VOC-nonmethane & Chemical source & Manually & $3.2 E-01$ & $2.4 E-02$ \\
\hline \multirow[t]{5}{*}{ * } & & 131 & VOC-nonmethane & Chemical source & Manually & $3.2 E-01$ & 4.4E-01 \\
\hline & \multirow[t]{4}{*}{687} & 010 & $P M-10$ & Chemical source & Manually & $1.7 \mathrm{E}-03$ & 5.0E-04 \\
\hline & & 011 & $P M-10$ & Chemical source & Manually & 1.7E-03 & $5.0 \mathrm{E}-04$ \\
\hline & & 033 & PM-10 & Chemical source & Manually & 1.9E-02 & $5.9 E-03$ \\
\hline & & 034 & PM-10 & Chemical source & Manually & $1.9 E-02$ & $5.9 E-03$ \\
\hline \multirow[t]{17}{*}{ CPP } & \multirow[t]{6}{*}{708} & \multirow[t]{6}{*}{001} & Carbon monoxide & Chemical source & Manually & $1.4 E+02$ & 1.7E+02 \\
\hline & & & Mercury compounds & Chemical source & Manually & $1.8 E-02$ & 2.3E- 02 \\
\hline & & & Nitric acid & Chemical source & Manually & $1.7 E+01$ & $2.2 E+01$ \\
\hline & & & Nitrogen oxides & Chemical source & Manually & $2.7 E+02$ & $3.4 \mathrm{E}+02$ \\
\hline & & & Sulfur oxides & Chemical source & Manually & $2.4 E+00$ & $3.0 E+00$ \\
\hline & & & VOC-nonmethane & Chemical source & Manually & $9.2 E+00$ & $1.2 E+01$ \\
\hline & \multirow[t]{6}{*}{787} & \multirow[t]{6}{*}{001} & Carbon monoxide & Fuel buming equipment & Manually & $1.5 E+02$ & $4.6 \mathrm{E}+01$ \\
\hline & & & $\mathrm{CO}$ & Fuel burning equipment & Manually & & $4.0 E+01$ \\
\hline & & & Nitrogen oxides & Fuel burning equipment & Manually & $1.0 E+02$ & $3.4 E+01$ \\
\hline & & & PM-10 & Fuel burning equipment & Manually & $0.0 E+00$ & 4.1E-01 \\
\hline & & & Sulfur oxides & Fuel burning equipment & Manually & $8.8 E+01$ & $7.0 E+00$ \\
\hline & & & VOC-nonmethane & Fuel burning equipment & Manually & 4.0E-01 & 1.3E-01 \\
\hline & \multirow[t]{3}{*}{792} & 001 & PM-10 & Chemical source & Manually & $2.5 E-02$ & 7.7E-03 \\
\hline & & 002 & $P M-10$ & Chemical source & Manually & $8.0 E-04$ & 4.0E-04 \\
\hline & & 003 & $P M-10$ & Chemical source & Manually & $8.0 E-04$ & 4.0E-04 \\
\hline & 793 & 002 & PM-10 & Chemical source & Manually & $2.0 \mathrm{E}-01$ & $5.9 E-03$ \\
\hline & 794 & 001 & PM-10 & Chemical source & Manually & $1.1 E+00$ & $2.8 \mathrm{E}-02$ \\
\hline
\end{tabular}

* Not significant sources 
Table 35. (continued)

\begin{tabular}{|c|c|c|c|c|c|c|c|}
\hline \multirow[b]{2}{*}{ Area } & \multirow[b]{2}{*}{ Bldg } & \multirow[b]{2}{*}{ Vent } & \multirow[b]{2}{*}{ Pollutant } & \multirow[b]{2}{*}{ Source type } & \multirow{2}{*}{$\begin{array}{c}\text { Calc } \\
\text { method }\end{array}$} & \multicolumn{2}{|c|}{ Emissions } \\
\hline & & & & & & $\mathrm{lb} / \mathrm{hr}$ & ton/yr \\
\hline * GRP & 001 & & Acetaldehyde & Fuel burning equipment & Manually & & $1.2 E-04$ \\
\hline$*$ & & & Benzene & Fuel burning equipment & Manually & & 7.0E-04 \\
\hline$*$ & & & $\mathrm{CO}$ & Fuel burning equipment & Manually & & 7.4E-01 \\
\hline * & & & Formaldehyde & Fuel burning equipment & Manually & & $2.2 E-04$ \\
\hline * & & & Nitrogen oxides & Fuel burning equipment & Manually & & $3.5 E+00$ \\
\hline * & & & PM-10 & Fuel buming equipment & Manually & & $1.0 E-01$ \\
\hline * & & & Sulfur oxides & Fuel buming equipment & Manually & & 4.3E-D1 \\
\hline * & & & Toluene & Fuel burning equipment & Manually & & 2.5E-04 \\
\hline * & & & $\begin{array}{l}\text { Total Organic } \\
\text { compounds }\end{array}$ & Fuel burning equipment & Manually & & 1.3E-01 \\
\hline * & & & Xylene & Fuel burning equipment & Manually & & $1.8 E-04$ \\
\hline * & & 002 & VOC-nonmethane & Storage tank - VOC & Manually & & $1.2 E-01$ \\
\hline$*$ & & 003 & Hydrofluoric Acid & Chemical source & Manually & & $1.0 \mathrm{E}-02$ \\
\hline * & & & PM-10 & Chemical source & Manually & & 4.9E-01 \\
\hline * & & & Sulfuric acid & Chemical source & Manually & & $1.0 E-03$ \\
\hline * & & & VOC-nonmethane & Chemical source & Manually & & $1.6 \mathrm{E}+00$ \\
\hline \multirow[t]{16}{*}{ NRF } & 620 & 012 & Arsenic & Fuel burning equipment & Manually & $0.0 E+00$ & $1.3 E-04$ \\
\hline & & & Cadmium & Fuel burning equipment & Manually & $0.0 E+00$ & $1.0 \mathrm{E}-04$ \\
\hline & & & Carbon monoxide & Fuel burning equipment & Manually & 1.3E-04 & $1.2 E+00$ \\
\hline & & & Chromium compounds & Fuel burning equipment & Manually & $0.0 \mathrm{E}+00$ & $1.0 E-04$ \\
\hline & & & Formaldehyde & Fuel burning equipment & Manually & $0.0 \mathrm{E}+00$ & $1.4 \mathrm{E}-02$ \\
\hline & & & Lead compounds & Fuel burning equipment & Manually & $0.0 \mathrm{E}+00$ & $2.8 E-04$ \\
\hline & & & Manganese & Fuel burning equipment & Manually & $0.0 \mathrm{E}+00$ & $1.9 E-04$ \\
\hline & & & Mercury compounds & Fuel burning equipment & Manually & $0.0 E+00$ & $1.0 E-04$ \\
\hline & & & Nickel & Fuel burning equipment & Manually & $0.0 E+00$ & 1.0E-04 \\
\hline & & & Nitrogen oxides & Fuel burning equipment & Manually & 5.3E-04 & 4.7E+00 \\
\hline & & & $P M-10$ & Fuel burning equipment & Manually & $6.0 E-05$ & $5.4 \mathrm{E}-01$ \\
\hline & & & Selenium compounds & Fuel burning equipment & Manually & $0.0 E+00$ & 4.7E-04 \\
\hline & & & Sulfur oxides & Fuel burning equipment & Manually & $6.2 E-04$ & $5.4 E+00$ \\
\hline & & & VOC-methane & Fuel burning equipment & Manually & $0.0 E+00$ & $1.2 \mathrm{E}-02$ \\
\hline & & & VOC-nonmethane & Fuel burning equipment & Manually & $1.0 \mathrm{E}-05$ & 4.7E-02 \\
\hline & & & Zinc metal & Fuel burning equipment & Manually & $0.0 E+00$ & $1.3 E-04$ \\
\hline \multirow[t]{16}{*}{ NRF } & 620 & 013 & Arsenic & Fuel burning equipment & Manually & $0.0 \mathrm{E}+00$ & $0.0 E+00$ \\
\hline & & & Cadmium & Fuel burning equipment & Manually & $0.0 \mathrm{E}+00$ & $0.0 \mathrm{E}+\infty 0$ \\
\hline & & & Carbon monoxide & Fuel burning equipment & Manually & $0.0 \mathrm{E}+00$ & $0.0 \mathrm{E}+00$ \\
\hline & & & Chromium compounds & Fuel burning equipment & Manually & $0.0 E+00$ & $0.0 E+00$ \\
\hline & & & Lead compounds & Fuel burning equipment & Manually & $0.0 \mathrm{E}+00$ & $0.0 \mathrm{E}+00$ \\
\hline & & & Manganese & Fuel buming equipment & Manually & $0.0 \mathrm{E}+00$ & $0.0 E+00$ \\
\hline & & & Mercury compounds & Fuel burning equipment & Manually & $0.0 \mathrm{E}+00$ & $0.0 \mathrm{E}+00$ \\
\hline & & & Nickel & Fuel burning equipment & Manually & $0.0 \mathrm{E}+00$ & $0.0 E+00$ \\
\hline & & & Nitrogen oxides & Fuel burning equipment & Manually & $0.0 \mathrm{E}+00$ & $0.0 \mathrm{E}+00$ \\
\hline & & & PM-10 & Fuel burning equipment & Manually & $0.0 E+00$ & $0.0 \mathrm{E}+00$ \\
\hline & & & Sulfur oxides & Fuel burning equipment & Manually & $0.0 \mathrm{E}+00$ & $0.0 E+00$ \\
\hline & & & VOC-methane & Fuel burning equipment & Manually & $0.0 E+00$ & $0.0 E+00$ \\
\hline & & & VOC-nonmethane & Fuel burning equipment & Manually & $0.0 E+00$ & $0.0 \mathrm{E}+00$ \\
\hline & & 014 & Arsenic & Fuel burning equipment & Manually & $0.0 E+00$ & $0.0 \mathrm{E}+00$ \\
\hline & & & Cadmium & Fuel burning equipment & Manually & $0.0 E+00$ & $0.0 E+00$ \\
\hline & & & Carbon monoxide & Fuel burning equipment & Manually & $0.0 E+00$ & $0.0 \mathrm{E}+00$ \\
\hline
\end{tabular}

* Not significant sources 
Table 35. (continued)

\begin{tabular}{|c|c|c|c|c|c|c|c|}
\hline \multirow[b]{2}{*}{ Area } & \multirow[b]{2}{*}{ Bldg } & \multirow[b]{2}{*}{ Vent } & \multirow[b]{2}{*}{ Pollutant } & \multirow[b]{2}{*}{ Source type } & \multirow{2}{*}{$\begin{array}{c}\text { Calc } \\
\text { method }\end{array}$} & \multicolumn{2}{|c|}{ Emissions } \\
\hline & & & & & & $\mathrm{lb} / \mathrm{hr}$ & ton/yr \\
\hline \multirow[t]{11}{*}{ NRF } & 620 & 014 & Chromium compounds & Fuel burning equipment & Manually & $0.0 E+00$ & $0.0 \mathrm{E}+00$ \\
\hline & & & Formaldehyde & Fuel buming equipment & Manually & $0.0 \mathrm{E}+00$ & $0.0 \mathrm{E}+00$ \\
\hline & & & Lead compounds & Fuel burning equipment & Manually & $0.0 E+00$ & $0.0 E+00$ \\
\hline & & & Manganese & Fuel burning equipment & Manually & $0.0 E+00$ & $0.0 E+00$ \\
\hline & & & Mercury compounds & Fuel burning equipment & Manually & $0.0 E+00$ & $0.0 E+00$ \\
\hline & & & Nickel & Fuel burning equipment & Manually & $0.0 \mathrm{E}+00$ & $0.0 E+00$ \\
\hline & & & Nitrogen oxides & Fuel burning equipment & Manually & $0.0 E+00$ & $0.0 E+00$ \\
\hline & & & PM-10 & Fuel burning equipment & Manually & $0.0 E+00$ & $0.0 E+00$ \\
\hline & & & Sulfur oxides & Fuel burning equipment & Manually & $0.0 E+00$ & $0.0 \mathrm{E}+00$ \\
\hline & & & VOC-methane & Fuel burning equipment & Manually & $0.0 E+00$ & $0.0 E+00$ \\
\hline & & & VOC-nonmethane & Fuel burning equipment & Manually & $0.0 E+00$ & $0.0 E+00$ \\
\hline * & 635 & 006 & Benzene & Fuel burning equipment & Manually & $1.6 \mathrm{E}-03$ & $1.0 \mathrm{E}-05$ \\
\hline * & & & Carbon monoxide & Fuel burning equipment & Manually & $1.6 E+00$ & 1.3E-02 \\
\hline * & & & N-Dioctyl Phthalate & Fuel burning equipment & Manually & & \\
\hline$*$ & & & Nitrogen oxides & Fuel burning equipment & Manually & 7.6E+00 & $6.0 \mathrm{E}-02$ \\
\hline * & & & $P M-10$ & Fuel burning equipment & Manually & 5.3E-01 & 4.2E-03 \\
\hline * & & & Sulfur oxides & Fuel burning equipment & Manually & 5.0E-01 & $4.0 \mathrm{E}-03$ \\
\hline * & & & VOC-nonmethane & Fuel burning equipment & Manually & 5.6E-01 & 4.5E-03 \\
\hline * & & 007 & Benzene & Fuel burning equipment & Manually & 1.6E-03 & 1.0E-05 \\
\hline * & & & Carbon monoxide & Fuel burning equipment & Manually & $1.6 \mathrm{E}+00$ & 1.3E-02 \\
\hline * & & & Nitrogen oxides & Fuel burning equipment & Manually & $7.6 \mathrm{E}+00$ & $6.0 E-02$ \\
\hline * & & & $P M-10$ & Fuel burning equipment & Manualiy & 5.3E-01 & 4.2E-03 \\
\hline * & & & Sulfur oxides & Fuel burning equipment & Manually & 5.0E-01 & 4.0E-03 \\
\hline * & & & VOC-nonmethane & Fuel burning equipment & Manually & $5.6 \mathrm{E}-01$ & 4.5E-03 \\
\hline * & 686 & 016 & Acetaldehyde & Fuel burning equipment & Manually & 3.1E-04 & $0.0 \mathrm{E}+00$ \\
\hline * & & & Benzene & Fuel burning equipment & Manually & $9.6 \mathrm{E}-03$ & $1.0 \mathrm{E}-04$ \\
\hline * & & & Carbon monoxide & Fuel burning equipment & Manually & $1.0 \mathrm{E}+01$ & 1.1E-01 \\
\hline$*$ & & & Formaldehyde & Fuel burning equipment & Manually & $9.7 E-04$ & 1.0E-05 \\
\hline * & & & Nitrogen oxides & Fuel burning equipment & Manually & $3.9 E+01$ & 4.2E-01 \\
\hline * & & & PM-10 & Fuel burning equipment & Manually & $7.1 E-01$ & 7.6E-03 \\
\hline * & & & Sulfur oxides & Fuel burning equipment & Manually & 5.6E-01 & $6.0 E-03$ \\
\hline * & & & Toluene & Fuel burning equipment & Manually & $3.5 E-03$ & 4.0E-05 \\
\hline NRF & 686 & 016 & VOC-methane & Fuel burning equipment & Manually & $1.0 \mathrm{E}+00$ & 1.1E-02 \\
\hline * & & & Xylene & Fuel burning equipment & Manually & 2.4E-03 & 3.0E-05 \\
\hline * & & 017 & Acetaldehyde & Fuel burning equipment & Manually & 3.1E-04 & $0.0 E+00$ \\
\hline * & & & Benzene & Fuel burning equipment & Manually & $9.6 \mathrm{E}-03$ & 1.0E-04 \\
\hline * & & & Carbon monoxide & Fuel burning equipment & Manuaily & $1.0 \mathrm{E}+01$ & 1.1E-01 \\
\hline * & & & Formaldehyde & Fuel burning equipment & Manually & $9.7 E-04$ & $1.0 E-05$ \\
\hline * & & & Nitrogen oxides & Fuel burning equipment & Manually & $3.9 E+01$ & 4.3E-01 \\
\hline \pm & & & $P M-10$ & Fuel burning equipment & Manually & $7.1 E-01$ & 7.7E-03 \\
\hline * & & & Sulfur oxides & Fuel burning equipment & Manually & 5.6E-01 & 6.1E-03 \\
\hline * & & & Toluene & Fuel burning equipment & Manually & 3.5E-03 & 4.0E-05 \\
\hline * & & & VOC-methane & Fuel burning equipment & Manually & $1.0 \mathrm{E}+00$ & $1.1 \mathrm{E}-02$ \\
\hline * & & & Xylene & Fuel burning equipment & Manually & 2.4E-03 & $3.0 \mathrm{E}-05$ \\
\hline${ }^{*} \mathrm{NRF}$ & 686 & 018 & Acetaldehyde & Fuel burning equipment & Manually & 3.1E-04 & $0.0 \mathrm{E}+00$ \\
\hline * & & & Benzene & Fuel burning equipment & Manually & $9.6 E-03$ & $1.0 E-04$ \\
\hline * & & & Carbon monoxide & Fuel burning equipment & Manually & $1.0 E+01$ & 1.1E-01 \\
\hline * & & & Formaldehyde & Fuel burning equipment & Manually & $9.7 E-04$ & 1.0E-05 \\
\hline * & & & Nitrogen oxides & Fuel burning equipment & Manually & $3.9 E+01$ & 4.1E-01 \\
\hline
\end{tabular}

* Not significant source 
Table 35. (continued)

\begin{tabular}{|c|c|c|c|c|c|c|c|}
\hline \multirow[b]{2}{*}{ Area } & \multirow[b]{2}{*}{ Bldg } & \multirow[b]{2}{*}{ Vent } & \multirow[b]{2}{*}{ Pollutant } & \multirow[b]{2}{*}{ Source type } & \multirow{2}{*}{$\begin{array}{l}\text { Calc } \\
\text { method }\end{array}$} & \multicolumn{2}{|c|}{ Emissions } \\
\hline & & & & & & $\mathrm{lb} / \mathrm{hr}$ & $\operatorname{ton} / \mathrm{yr}$ \\
\hline${ }^{*}$ NRF & 686 & 018 & PM-10 & Fuel burning equipment & Manually & 7.1E-01 & $7.4 E-03$ \\
\hline * & & & Sulfur oxides & Fuel burning equipment & Manually & 5.6E-01 & 5.9E-03 \\
\hline * & & & Toluene & Fuel burning equipment & Manually & $3.5 E-03$ & 4.0E-05 \\
\hline * & & & VOC-methane & Fuel burning equipment & Manually & $1.0 \mathrm{E}+00$ & 1.1E-02 \\
\hline$*$ & & 019 & Acetaldehyde & Fuel burning equipment & Manually & $3.1 E-04$ & $0.0 E+00$ \\
\hline * & & & Benzene & Fuel burning equipment & Manually & $9.6 E-03$ & 1.1E-04 \\
\hline * & & & Carbon monoxide & Fuel burning equipment & Manually & $1.0 E+01$ & $1.2 E-01$ \\
\hline$*$ & & & Formaldehyde & Fuel burning equipment & Manually & 9.7E-04 & 1.0E-05 \\
\hline * & & & Nitrogen oxides & Fuel burning equipment & Manually & $3.9 E+01$ & 4.4E-01 \\
\hline * & & & $P M-10$ & Fuel burning equipment & Manually & 7.1E-01 & 7.9E-03 \\
\hline * & & & Sulfur oxides & Fuel burning equipment & Manually & $5.6 \mathrm{E}-01$ & $6.2 E-03$ \\
\hline * & & & Toluene & Fuel burning equipment & Manually & 3.5E-03 & 4.0E-05 \\
\hline * & & & VOC-methane & Fuel burning equipment & Manually & $1.0 E+00$ & 1.1E-04 \\
\hline * & & & Xylene & Fuel burning equipment & Manually & $2.4 E-03$ & $3.0 \mathrm{E}-05$ \\
\hline * & $759 A$ & 001 & VOC-nonmethane & Storage tank - VOC & Manually & $1.4 E-03$ & $6.2 \mathrm{E}-03$ \\
\hline$*$ & 773 & 001 & VOC-nonmethane & Storage tank - VOC & Manually & $3.9 E-03$ & 1.7E-02 \\
\hline * & $\mathrm{MCM}$ & ALL & Acetone & Chemical source & Manually & $0.0 E-00$ & $0.0 \mathrm{E}-00$ \\
\hline * & & & Chromium compounds & Chemical source & Manually & $0.0 E-00$ & $0.0 \mathrm{E}-00$ \\
\hline * & & & $\begin{array}{l}\text { Cumene } \\
\text { Hydroperoxide }\end{array}$ & Chemical source & Manually & $0.0 E-00$ & $0.0 E-00$ \\
\hline * & & & Formaldehyde & Chemical source & Manually & $0.0 E-00$ & $0.0 E-00$ \\
\hline * & & & Hexane & Chemical source & Manually & $0.0 \mathrm{E}-00$ & $0.0 E-00$ \\
\hline * & & & Hydrazine & Chemical source & Manually & $0.0 \mathrm{E}-00$ & $0.0 E-00$ \\
\hline * & & & Lead compounds & Chemical source & Manually & $0.0 \mathrm{E}-00$ & $0.0 E-00$ \\
\hline * & & & Methyl chloroform & Chemical source & Manually & $0.0 \mathrm{E}-00$ & $0.0 E-00$ \\
\hline * & & & Methyl ethyl ketone & Chemical source & Manually & $0.0 \mathrm{E}-00$ & $0.0 E-00$ \\
\hline$*$ & & & Methylene chloride & Chemical source & Manually & $0.0 E-00$ & $0.0 E-00$ \\
\hline * & & & Sulfuric acid & Chemical source & Manually & $0.0 E-00$ & $0.0 E-00$ \\
\hline * & & & Toluene & Chemical source & Manually & $0.0 E-00$ & $0.0 E-00$ \\
\hline * & & & Xylene & Chemical source & Manually & $0.0 E-00$ & $0.0 E-00$ \\
\hline${ }^{*} \mathrm{NRF}$ & PNT & $A L L$ & $P M-10$ & Chemical source & Manually & $0.0 E-00$ & $0.0 \mathrm{E}-00$ \\
\hline$\star$ & & & VOC-nonmethane & Chemical source & Manually & $0.0 E=00$ & $0.0 E-00$ \\
\hline * & PRT & 005 & Benzene & Fuel burning equipment & Manually & $1.2 \mathrm{E}-03$ & $1.0 \mathrm{E}-05$ \\
\hline * & & & Carbon monoxide & Fuel burning equipment & Manually & $1.2 E+00$ & 5.9E-03 \\
\hline * & & & Nitrogen oxides & Fuel burning equipment & Manually & $5.5 E+00$ & 2.7E-02 \\
\hline * & & & PM-10 & Fuel buming equipment & Manually & $3.9 E-01$ & $1.9 E-03$ \\
\hline * & & & Sulfur oxides & Fuel burning equipment & Manually & $3.6 E-01$ & $1.8 \mathrm{E}-03$ \\
\hline$*$ & & & Toluene & Fuel burning equipment & Manually & 5.1E-04 & $0.0 \mathrm{E}+00$ \\
\hline$\star$ & & & VOC-nonmethane & Fuel burning equipment & Manually & 4.1E-01 & 2.0E-03 \\
\hline * & & & Xylene & Fuel burning equipment & Manually & 3.6E-04 & $0.0 E+00$ \\
\hline *PER & 601 & 010 & $\mathrm{co}$ & Fuel burning equipment & Manually & & $5.9 \mathrm{E}-03$ \\
\hline * & & & Nitrogen oxides & Fuel burning equipment & Manually & & $2.0 \mathrm{E}-02$ \\
\hline$\star$ & & & $P M-10$ & Fuel burning equipment & Manually & & 4.3E-04 \\
\hline$\star$ & & & Sulfur oxides & Fuel burning equipment & Manually & & 8.0E-02 \\
\hline$*$ & & & $\begin{array}{l}\text { Total Organic } \\
\text { compounds }\end{array}$ & Fuel burning equipment & Manually & & $7.8 E-04$ \\
\hline * PER & $601 \mathrm{~A}$ & 010 & $\mathrm{CO}$ & Fuel burning equipment & Manually & & 1.0E-03 \\
\hline$*$ & & & Nitrogen oxides & Fuel burning equipment & Manually & & 3.6E-03 \\
\hline
\end{tabular}

* Not significant sources 
Table 35. (continued)

\begin{tabular}{|c|c|c|c|c|c|c|c|}
\hline \multirow[b]{2}{*}{ Area } & \multirow[b]{2}{*}{ Bldg } & \multirow[b]{2}{*}{ Vent } & \multirow[b]{2}{*}{ Pollutant } & \multirow[b]{2}{*}{ Source type } & \multirow{2}{*}{$\begin{array}{l}\text { Calc } \\
\text { method }\end{array}$} & \multicolumn{2}{|c|}{ Emissions } \\
\hline & & & & & & $\mathrm{lb} / \mathrm{hr}$ & ton/yr \\
\hline \multirow{25}{*}{$\begin{array}{l}\text { *PER } \\
* \\
*\end{array}$} & \multirow[t]{3}{*}{$601 \mathrm{~A}$} & \multirow[t]{3}{*}{010} & $P M-10$ & Fuel burning equipment & Manually & & 8.0E-05 \\
\hline & & & Sulfur oxides & Fuel burning equipment & Manually & & $1.5 E-02$ \\
\hline & & & $\begin{array}{l}\text { Total Organic } \\
\text { compounds }\end{array}$ & Fuel burning equipment & Manually & & 1.4E-04 \\
\hline & \multirow[t]{5}{*}{612} & \multirow[t]{5}{*}{006} & $\mathrm{CO}$ & Fuel burning equipment & Manually & & 8.7E-03 \\
\hline & & & Nitrogen oxides & Fuel burning equipment & Manually & & 3.1E-02 \\
\hline & & & PM-10 & Fuel burning equipment & Manually & & 6.9E-04 \\
\hline & & & Sulfur oxides & Fuel burning equipment & Manually & & 3.1E-02 \\
\hline & & & $\begin{array}{l}\text { Total Organic } \\
\text { compounds }\end{array}$ & Fuel burning equipment & Manually & & $1.2 \mathrm{E}-03$ \\
\hline & \multirow[t]{12}{*}{613} & \multirow[t]{12}{*}{009} & $1,1,1$-Trichloroethane & Fuel burning equipment & System & $0.0 E+\infty$ & $0.0 E+00$ \\
\hline & & & Benzene & Fuel burning equipment & System & $0.0 E+00$ & $0.0 \mathrm{E}+00$ \\
\hline & & & Carbon monoxide & Fuel burning equipment & System & $2.0 \mathrm{E}-02$ & $0.0 \mathrm{E}+00$ \\
\hline & & & Formaldehyde & Fuel burning equipment & System & $1.3 E-04$ & $0.0 \mathrm{E}+00$ \\
\hline & & & Naphthalene & Fuel burning equipment & System & $0.0 \mathrm{E}+00$ & $0.0 E+00$ \\
\hline & & & Nitrogen oxides & Fuel burning equipment & System & $8.0 E-02$ & $0.0 E+00$ \\
\hline & & & Xylenes & Fuel burning equipment & System & $0.0 E+00$ & $0.0 \mathrm{E}+00$ \\
\hline & & & $P M-10$ & Fuel burning equipment & System & $4.0 E-03$ & $0.0 E+\infty 0$ \\
\hline & & & Sulfur oxides & Fuel burning equipment & System & $5.8 E-01$ & $0.0 E+00$ \\
\hline & & & Toluene & Fuel burning equipment & System & 2.0E-05 & $0.0 E+00$ \\
\hline & & & VOC-methane & Fuel burning equipment & System & 8.6E-04 & $0.0 E+00$ \\
\hline & & & VOC-nonmethane & Fuel burning equipment & System & $1.4 \mathrm{E}-03$ & $0.0 E+00$ \\
\hline & \multirow[t]{5}{*}{620} & \multirow[t]{5}{*}{023} & 1,1,1-Trichloroethane & Fuel burning equipment & System & $0.0 E+00$ & $0.0 E+00$ \\
\hline & & & Benzene & Fuel burning equipment & System & $0.0 E+00$ & $0.0 E+00$ \\
\hline & & & Carbon monoxide & Fuel burning equipment & System & $6.0 \mathrm{E}-02$ & 4.6E-02 \\
\hline & & & Formaldehyde & Fuel burning equipment & System & 4.0E-04 & 3.1E-04 \\
\hline & & & Naphthalene & Fuel burning equipment & System & $1.0 \mathrm{E}-05$ & 1.0E-05 \\
\hline \multirow[t]{7}{*}{ PER } & \multirow[t]{7}{*}{620} & \multirow[t]{7}{*}{023} & Nitrogen oxides & Fuel burning equipment & System & 2.4E-01 & $1.9 E-01$ \\
\hline & & & Xylenes & Fuel burning equipment & System & $0.0 \mathrm{E}+00$ & $0.0 E+00$ \\
\hline & & & PM-10 & Fuel burning equipment & System & $1.2 E-02$ & $9.3 E-03$ \\
\hline & & & Sulfur oxides & Fuel burning equipment & System & $1.7 E+00$ & $1.3 E+00$ \\
\hline & & & Toluene & Fuel burning equipment & System & $7.0 \mathrm{E}-05$ & 6.0E-05 \\
\hline & & & VOC-methane & Fuel burning equipment & System & 2.6E-03 & 2.0E-03 \\
\hline & & & VOC-nonmethane & Fuel burning equipment & System & 4.1E-03 & $3.2 \mathrm{E}-03$ \\
\hline * & \multirow[t]{5}{*}{632} & \multirow[t]{5}{*}{007} & $\mathrm{CO}$ & Fuel buming equipment & Manually & & 2.7E-03 \\
\hline * & & & Nitrogen oxides & Fuel burning equipment & Manually & & $9.8 E-03$ \\
\hline * & & & PM-10 & Fuel burning equipment & Manually & & 2.1E-04 \\
\hline * & & & Sulfur oxides & Fuel burning equipment & Manually & & 4.0E-02 \\
\hline * & & & $\begin{array}{l}\text { Total Organic } \\
\text { compounds }\end{array}$ & Fuel burning equipment & Manually & & $3.8 E-04$ \\
\hline$*$ & 722 & 001 & VOC-nonmethane & Storage tank - VOC & System & $0.0 E \div 00$ & 8.7E-03 \\
\hline \multirow[t]{6}{*}{ PER } & 755 & 001 & 1,1-Dichloroethane & Chemical source & Manually & 1.0E-05 & $0.0 E+00$ \\
\hline & & & Acetone & Chemical source & Manually & 3.3E-03 & 4.7E-03 \\
\hline & & & Antimony & Chemical source & Manually & $5.0 E-04$ & 2.0E-04 \\
\hline & & & Arsenic & Chemical source & Manually & $5.0 E-04$ & 2.0E-04 \\
\hline & & & Barium & Chemical source & Manually & 5.0E-04 & 2.0E-04 \\
\hline & & & Benzene & Chemical source & Manually & 4.6E-03 & $1.9 E-03$ \\
\hline
\end{tabular}

* Not significant sources 
Table 35. (continued)

\begin{tabular}{|c|c|c|c|c|c|c|c|}
\hline \multirow[b]{2}{*}{ Area } & \multirow[b]{2}{*}{ Bldg } & \multirow[b]{2}{*}{ Vent } & \multirow[b]{2}{*}{ Pollutant } & \multirow[b]{2}{*}{ Source type } & \multirow{2}{*}{$\begin{array}{l}\text { Calc } \\
\text { method }\end{array}$} & \multicolumn{2}{|c|}{ Emissions } \\
\hline & & & & & & $\mathrm{lb} / \mathrm{hr}$ & $\operatorname{ton} / \mathrm{yr}$ \\
\hline \multirow[t]{24}{*}{$\overline{\text { PER }}$} & \multirow[t]{24}{*}{755} & \multirow[t]{24}{*}{001} & Beryllium & Chemical source & Manually & 5.0E-04 & $2.0 E-04$ \\
\hline & & & Bromine & Chemical source & Manually & $3.2 E-04$ & 1.3E-04 \\
\hline & & & Cadmium & Chemical source & Manually & $5.0 E-04$ & 2.0E-04 \\
\hline & & & Carbon disulfide & Chemical source & Manually & 5.0E-04 & $2.0 E-04$ \\
\hline & & & Carbon monoxide & Chemical source & Manually & 5.0E-02 & $6.5 E-02$ \\
\hline & & & Chloroform & Chemical source & Manually & $0.0 E+00$ & $0.0 E+00$ \\
\hline & & & Chromium compounds & Chemical source & Manually & $5.0 E-04$ & $2.0 E-04$ \\
\hline & & & Cyanide & Chemical source & Manually & 5.0E-04 & 2.0E-04 \\
\hline & & & Diethanolamine & Chemical source & Manually & 5.0E-04 & $2.0 E-04$ \\
\hline & & & Diethyl phthalate & Chemical source & Manually & $3.5 E-04$ & $1.4 E-04$ \\
\hline & & & Hydrochloric acid & Chemical source & Manually & $1.5 E+00$ & $2.0 E+00$ \\
\hline & & & lodine & Chemical source & Manually & $5.0 E-04$ & $2.0 \mathrm{E}-04$ \\
\hline & & & Iron oxide fume & Chemical source & Manually & 5.0E-04 & 2.0E-04 \\
\hline & & & Lead compounds & Chemical source & Manually & $5.0 E-04$ & 2.0E-04 \\
\hline & & & Manganese & Chemical source & Manually & 5.0E-04 & 2.0E-04 \\
\hline & & & Mercury compounds & Chemical source & Manually & $0.0 E+00$ & $0.0 E+00$ \\
\hline & & & Methyl alcohol & Chemical source & Manually & 1.7E+01 & 7.0E-02 \\
\hline & & & Methyl ethyl ketone & Chemical source & Manually & $0.0 E+00$ & $0.0 E+00$ \\
\hline & & & Methylene chloride & Chemical source & Manually & $1.0 \mathrm{E}-05$ & 1.6E-03 \\
\hline & & & Naphthalene & Chemical source & Manually & $0.0 E+00$ & $0.0 E+00$ \\
\hline & & & Nickel & Chemical source & Manually & 5.0E-04 & 2.0E-05 \\
\hline & & & Nitrogen oxides & Chemical source & Manually & $1.1 E+00$ & $1.4 E+00$ \\
\hline & & & Pentachlorophenol & Chernical source & Manually & $5.0 E-04$ & 2.0E-05 \\
\hline & & & Phenol & Chemical source & Manually & $0.0 E+00$ & $0.0 E+00$ \\
\hline \multirow[t]{11}{*}{ PER } & \multirow[t]{11}{*}{755} & \multirow[t]{11}{*}{001} & PM-10 & Chemical source & Manually & $2.8 E-02$ & 3.6E-02 \\
\hline & & & Pyridine & Chemical source & Manually & $0.0 E+00$ & $0.0 E+00$ \\
\hline & & & Selenium compounds & Chemical source & Manually & $5.0 \mathrm{E}-04$ & $2.1 \mathrm{E}-04$ \\
\hline & & & Silicon & Chemical source & Manually & 5.0E-04 & 2.1E-04 \\
\hline & & & Silver metal & Chemical source & Manually & $5.0 \mathrm{E}-04$ & $2.0 E-04$ \\
\hline & & & Sulfur oxides & Chemical source & Manually & $1.0 \mathrm{E}+00$ & 1.3E+00 \\
\hline & & & Tetrachloroethylene & Chemical source & Manually & $4.0 E-05$ & $2.0 \mathrm{E}-05$ \\
\hline & & & Thallium & Chemical source & Manually & $5.0 E-04$ & 2.0E-04 \\
\hline & & & Toluene & Chemical source & Manually & 1.0E-05 & $0.0 E+00$ \\
\hline & & & VOC-nonmethane & Chemical source & Manually & $5.9 E-04$ & 7.6E-04 \\
\hline & & & Xylene & Chemical source & Manually & 1.3E-03 & $5.3 E-04$ \\
\hline${ }^{*}$ PER & GRP & 001 & Acetaldehyde & Chemical source & Manually & & 4.0E-05 \\
\hline * & & & Benzene & Chemical source & Manually & & $5.0 E-05$ \\
\hline$*$ & & & $\mathrm{CO}$ & Chemical source & Manually & & $5.0 E-02$ \\
\hline * & & & Formaldehyde & Chemical source & Manually & & 6.0E-05 \\
\hline * & & & Nitrogen oxides & Chemical source & Manually & & 2.4E-01 \\
\hline * & & & $P M-10$ & Chemical source & Manually & & 1.7E-02 \\
\hline * & & & Sulfur oxides & Chemical source & Manually & & $1.5 E-02$ \\
\hline * & & & Toluene & Chemical source & Manually & & 2.0E-05 \\
\hline${ }^{*} P E R$ & GRP & 001 & TOC & Chemical source & Manually & & $1.8 \mathrm{E}-02$ \\
\hline$\star$ & & & Xylene & Chemical source & Manually & & $1.0 E-05$ \\
\hline * & & 002 & VOC-nonmethane & Storage tank - VOC & Manually & & $1.3 E-02$ \\
\hline
\end{tabular}

* Not significant sources 
Table 35. (continued)

\begin{tabular}{|c|c|c|c|c|c|c|c|}
\hline \multirow[b]{2}{*}{ Area } & \multirow[b]{2}{*}{ Bldg } & \multirow[b]{2}{*}{ Vent } & \multirow[b]{2}{*}{ Pollutant } & \multirow[b]{2}{*}{ Source type } & \multirow{2}{*}{$\begin{array}{c}\text { Calc } \\
\text { method }\end{array}$} & \multicolumn{2}{|c|}{ Emissions } \\
\hline & & & & & & $\mathrm{lb} / \mathrm{hr}$ & ton/yr \\
\hline \multirow[t]{26}{*}{ TRA } & \multirow[t]{26}{*}{670} & \multirow[t]{13}{*}{046} & Acetaldehyde & Fuel burning equipment & System & 1.6E-04 & 3.3E-04 \\
\hline & & & Acrolein & Fuel burning equipment & System & $5.0 E-05$ & $1.0 \mathrm{E}-04$ \\
\hline & & & Benzene & Fuel burning equipment & System & $5.1 E-03$ & $1.0 \mathrm{E}-02$ \\
\hline & & & Carbon monoxide & Fuel buming equipment & System & $5.3 E+00$ & $1.1 E+01$ \\
\hline & & & Formaldehyde & Fuel buming equipment & System & 5.1E-04 & $1.0 \mathrm{E}-03$ \\
\hline & & & Nitrogen oxides & Fuel burning equipment & System & $2.0 E+01$ & 4.1E+01 \\
\hline & & & PM-10 & Fuel burning equipment & System & 3.7E-01 & 7.5E-01 \\
\hline & & & Propylene & Fuel burning equipment & System & $1.7 E-02$ & $3.6 \mathrm{E}-02$ \\
\hline & & & Sulfur oxides & Fuel buming equipment & System & $3.2 E+00$ & $6.5 E+00$ \\
\hline & & & Toluene & Fuel burning equipment & System & $1.7 E-03$ & 3.6E-03 \\
\hline & & & VOC-methane & Fuel burning equipment & System & 5.1E-02 & $1.0 \mathrm{E}-01$ \\
\hline & & & VOC-nonmethane & Fuel buming equipment & System & 5.1E-01 & $1.0 E+\infty 0$ \\
\hline & & & Xylene & Fuel buming equipment & System & $1.2 E-03$ & $2.4 \mathrm{E}-03$ \\
\hline & & \multirow[t]{13}{*}{053} & Acetaldehyde & Fuel burning equipment & System & $1.5 E-04$ & $2.3 E-04$ \\
\hline & & & Acrolein & Fuel burning equipment & System & 5.0E-05 & 7.0E-05 \\
\hline & & & Benzene & Fuel burning equipment & System & 4.7E-03 & 7.2E-03 \\
\hline & & & Carbon monoxide & Fuel buming equipment & System & $5.0 E+00$ & $7.5 E+00$ \\
\hline & & & Formaldehyde & Fuel burning equipment & System & 4.7E-04 & 7.2E-04 \\
\hline & & & Nitrogen oxides & Fuel burning equipment & System & $1.9 E+01$ & $2.8 E+01$ \\
\hline & & & PM-10 & Fuel burning equipment & System & $3.4 E-01$ & $5.2 E-01$ \\
\hline & & & Propylene & Fuel burning equipment & System & 1.6E-02 & 2.5E-02 \\
\hline & & & Sulfur oxides & Fuel burning equipment & System & $3.0 E+00$ & $4.5 E+00$ \\
\hline & & & Toluene & Fuel burning equipment & System & 1.6E-03 & 2.5E-03 \\
\hline & & & VOC-methane & Fuel burning equipment & System & 4.7E-02 & 7.2E-02 \\
\hline & & & VOC-nonmethane & Fuel burning equipment & System & $4.7 E-01$ & $7.2 E-01$ \\
\hline & & & Xylene & Fuel burning equipment & System & 1.1E-03 & 1.7E-03 \\
\hline \multirow[t]{14}{*}{ TRA } & \multirow[t]{13}{*}{674} & \multirow[t]{13}{*}{007} & Acetaldehyde & Fuel burning equipment & System & 2.1E-04 & $0.0 E+00$ \\
\hline & & & Acrolein & Fuel burning equipment & System & 7.0E-05 & $0.0 E+00$ \\
\hline & & & Benzene & Fuel burning equipment & System & 6.6E-03 & $2.0 E-05$ \\
\hline & & & Carbon monoxide & Fuel burning equipment & System & $7.0 \mathrm{E}+00$ & $2.0 \mathrm{E}-02$ \\
\hline & & & Formaldehyde & Fuel burning equipment & System & $6.6 \mathrm{E}-04$ & $0.0 E+00$ \\
\hline & & & Nitrogen oxides & Fuel burning equipment & System & $2.6 E+01$ & 7.7E-02 \\
\hline & & & $P M-10$ & Fuel burning equipment & System & 4.8E-01 & 1.4E-03 \\
\hline & & & Propylene & Fuel burning equipment & System & 2.3E-02 & 7.0E-05 \\
\hline & & & Sulfur oxides & Fuel burning equipment & System & 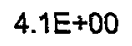 & $1.2 E-02$ \\
\hline & & & Toluene & Fuel burning equipment & System & 2.3E-03 & 1.0E-05 \\
\hline & & & VOC-methane & Fuel burning equipment & System & 6.6E-02 & $1.9 E-04$ \\
\hline & & & VOC-nonmethane & Fuel burning equipment & System & $6.6 E-01$ & $1.9 E-03$ \\
\hline & & & Xylene & Fuel buming equipment & System & $1.6 \mathrm{E}-03$ & $0.0 \mathrm{E}+00$ \\
\hline & 771 & 001 & PM-10 & Chemical source & Manually & $9.0 \mathrm{E}-01$ & $2.3 E+00$ \\
\hline${ }^{*}$ TRA & GRP & 001 & Acetaldehyde & Chemical source & Manually & & $1.8 E-04$ \\
\hline * & & & Benzene & Chemical source & Manually & & 2.2E-04 \\
\hline$*$ & & & $\mathrm{CO}$ & Chemical source & Manually & & $2.3 E-01$ \\
\hline * & & & Formaldehyde & Chemical source & Manually & & 2.8E-04 \\
\hline * & & & Nitrogen oxides & Chemical source & Manually & & $1.1 E+00$ \\
\hline$\star$ & & & PM-10 & Chemical source & Manually & & $7.5 E-02$ \\
\hline *TRA & GRP & 001 & Sulfur oxides & Chemical source & Manually & & 7.0E-02 \\
\hline * & & & Toluene & Chemical source & Manually & & 1.0E-04 \\
\hline * & & & TOC & Chemical source & Manually & & $8.4 E-02$ \\
\hline * & & & Xylene & Chemical source & Manually & & 7.0E-05 \\
\hline
\end{tabular}

* Not significant sources 
Table 35. (continued)

\begin{tabular}{|c|c|c|c|c|c|c|c|}
\hline \multirow[b]{2}{*}{ Area } & \multirow[b]{2}{*}{ Bldg } & \multirow[b]{2}{*}{ Vent } & \multirow[b]{2}{*}{ Pollutant } & \multirow[b]{2}{*}{ Source type } & \multirow{2}{*}{$\begin{array}{c}\text { Calc } \\
\text { method }\end{array}$} & \multicolumn{2}{|c|}{ Emissions } \\
\hline & & & & & & $\mathrm{lb} / \mathrm{hr}$ & ton $/ \mathrm{yr}$ \\
\hline TRA & & 002 & VOC-nonmethane & Storage tank - VOC & Manually & & $5.6 \mathrm{E}-02$ \\
\hline$*$ & & 003 & PM-10 & Chemical source & Manually & & 3.3E-01 \\
\hline * & & & VOC-nonmethane & Chemical source & Manually & & $1.2 \mathrm{E}+00$ \\
\hline \multirow[t]{11}{*}{ WMF } & \multicolumn{2}{|c|}{$628-36001$} & 1,1,1-Trichloroethane & Chemical source & Manually & 4.4E-01 & $1.9 E+00$ \\
\hline & & & Carbon tetrachloride & Chemical source & Manually & $6.2 E-01$ & 2.7E+00 \\
\hline & & & Chloroform & Chemical source & Manually & 2.3E-02 & $1.0 E-01$ \\
\hline & & & Methylene chloride & Chemical source & Manualiy & 1.7E-02 & $7.0 E-02$ \\
\hline & & & Trichloroethylene & Chemical source & Manually & $1.5 \mathrm{E}-02$ & $6.0 E-02$ \\
\hline & & & VOC-nonmethane & Chemical source & Manually & 2.1E+02 & $5.4 E+00$ \\
\hline & 635 & 002 & 1,1-Dichloroethane & Chemical source & Manually & $1.0 E-05$ & 5.0E-05 \\
\hline & & & Carbon tetrachloride & Chemical source & Manually & $6.1 E-03$ & 2.7E-02 \\
\hline & & & Methyl chloroform & Chemical source & Manually & 2.6E-04 & 1.1E-03 \\
\hline & & & Methylene chloride & Chemical source & Manually & 1.0E-05 & 7.0E-05 \\
\hline & & & Trichloroethylene & Chemical source & Manually & 1.7E-03 & 7.4E-03 \\
\hline \multirow[t]{7}{*}{ * } & 656 & 001 & $P M-10$ & & Manually & $1.6 E-01$ & 1.6E-01 \\
\hline & 734 & 001 & Carbon monoxide & Fuel burning equipment & Manually & $2.0 E+00$ & $1.0 E+00$ \\
\hline & & & Nitrogen oxides & Fuel burning equipment & Manually & $7.7 E+00$ & $1.5 E+01$ \\
\hline & & & $P M-10$ & Fuel burning equipment & Manually & 2.4E-01 & $1.0 E+00$ \\
\hline & & & Sulfur oxides & Fuel burning equipment & Manually & $1.5 \mathrm{E}+00$ & $3.0 E+00$ \\
\hline & & & VOC-methane & Fuel buming equipment & Manually & 2.0E-02 & 2.5E-04 \\
\hline & & & VOC-nonmethane & Fuel buming equipment & Manually & 2.0E-01 & 2.6E-03 \\
\hline *WMF & GRP & 001 & Acetaldehyde & Chemical source & Manually & & 2.0E-03 \\
\hline * & & & Benzene & Chemical source & Manually & & 2.0E-05 \\
\hline * & & & $\mathrm{CO}$ & Chemical source & Manually & & 5.6E-02 \\
\hline * & & & Formaldehyde & Chemical source & Manually & & 2.0E-05 \\
\hline * & & & Nitrogen oxides & Chemical source & Manually & & $3.6 E-01$ \\
\hline * & & & $P M-10$ & Chemical source & Manually & & $1.4 E-02$ \\
\hline * & & & Sulfur oxides & Chemical source & Manually & & $8.0 E-03$ \\
\hline * & & & Toluene & Chemical source & Manually & & $1.0 E-05$ \\
\hline * & & & $\begin{array}{l}\text { Total Organic } \\
\text { compounds }\end{array}$ & Chemical source & Manually & & 1.7E-02 \\
\hline * & & & VOC-nonmethane & Chemical source & Manually & & $0.0 E+00$ \\
\hline$\star$ & & & Xylene & Chemical source & Manually & & $1.0 E-05$ \\
\hline \multirow[t]{8}{*}{ TAN } & 607 & 039 & $P M-10$ & Chemical source & Manually & $3.0 E-05$ & 8.0E-05 \\
\hline & & & VOC-nonmethane & Chemical source & Manually & 3.9E-02 & 7.OE-05 \\
\hline & & 041 & $P M-10$ & Chemical source & Manually & $3.2 E-04$ & 1.9E-04 \\
\hline & & 119 & VOC-nonmethane & Chemical source & Manually & $3.4 E-03$ & $3.5 E-03$ \\
\hline & 629 & 002 & PM-10 & Chemical source & Manually & $1.0 E-01$ & $1.9 E-03$ \\
\hline & & & VOC-nonmethane & Chemical source & Manually & $3.9 E-02$ & $7.1 E-04$ \\
\hline & & 012 & $\mathrm{PM}-10$ & Chemical source & Manually & 2.8E-04 & $1.6 E-01$ \\
\hline & & & VOC-nonmethane & Chemical source & Manually & $2.0 E+00$ & 7.7E-02 \\
\hline \multirow[t]{3}{*}{ TAN } & 679 & 025 & VOC-nonmethane & Chemical source & Manualfy & $2.5 \mathrm{E}-04$ & $1.8 \mathrm{E}-04$ \\
\hline & & 026 & VOC-nonmethane & Chemical source & Manually & $2.5 E-04$ & $1.8 \mathrm{E}-04$ \\
\hline & & 027 & VOC-nonmethane & Chemical source & Manually & $2.5 E-04$ & $1.8 E-04$ \\
\hline
\end{tabular}

* Not significant sources 
Table 35. (continued)

\begin{tabular}{|c|c|c|c|c|c|c|c|}
\hline \multirow[b]{2}{*}{ Area } & \multirow[b]{2}{*}{ Bldg } & \multirow[b]{2}{*}{ Vent } & \multirow[b]{2}{*}{ Pollutant } & \multirow[b]{2}{*}{ Source type } & \multirow{2}{*}{$\begin{array}{l}\text { Calc } \\
\text { method }\end{array}$} & \multicolumn{2}{|c|}{ Emissions } \\
\hline & & & & & & $\mathrm{lb} / \mathrm{hr}$ & $\operatorname{ton} / \mathrm{yr}$ \\
\hline \multirow[t]{22}{*}{ TAN } & \multirow[t]{22}{*}{679} & \multirow[t]{12}{*}{067} & $1,1,1$-Trichloroethane & Fuel burning equipment & System & 1.0E-05 & $0.0 E+00$ \\
\hline & & & Benzene & Fuel burning equipment & System & 1.0E-05 & $0.0 E+00$ \\
\hline & & & Carbon monoxide & Fuel burning equipment & System & $3.0 E-01$ & $1.7 E-04$ \\
\hline & & & Formaldehyde & Fuel burning equipment & System & 2.0E-03 & $0.0 \mathrm{E}+00$ \\
\hline & & & Naphthalene & Fuel burning equipment & System & 7.0E-05 & $0.0 \mathrm{E}+00$ \\
\hline & & & Nitrogen oxides & Fuel burning equipment & System & $1.2 \mathrm{E}+00$ & $6.8 E-04$ \\
\hline & & & Xylenes & Fuel burning equipment & System & $1.0 \mathrm{E}-05$ & $0.0 E+00$ \\
\hline & & & PM-10 : & Fuel burning equipment & System & $6.0 E-02$ & $3.0 \mathrm{E}-05$ \\
\hline & & & Sulfur oxides & Fuel buming equipment & System & $8.6 E+00$ & 4.9E-03 \\
\hline & & & Toluene & Fuel burning equipment & System & 3.7E-04 & $0.0 E+00$ \\
\hline & & & VOC-methane & Fuel burning equipment & System & 3.1E-03 & $0.0 E+00$ \\
\hline & & & VOC-nonmethane & Fuel burning equipment & System & $1.2 E-02$ & $1.0 E-05$ \\
\hline & & \multirow[t]{10}{*}{068} & $1,1,1$-Trichloroethane & Fuel burning equipment & System & $1.0 E-05$ & $0.0 \mathrm{E}+00$ \\
\hline & & & Benzene & Fuel burning equipment & System & $1.0 E-05$ & $0.0 \mathrm{E}+00$ \\
\hline & & & Carbon monoxide & Fuel buming equipment & System & 2.2E-01 & $8.8 \mathrm{E}-02$ \\
\hline & & & Formaldehyde & Fuel burning equipment & System & $1.4 E-03$ & $5.8 E-04$ \\
\hline & & & Naphthalene & Fuel burning equipment & System & 5.0E-05 & 2.0E-05 \\
\hline & & & Nitrogen oxides & Fuel burning equipment & System & 8.6E-01 & $3.5 E-01$ \\
\hline & & & Xylenes & Fuel burning equipment & System & $0.0 \mathrm{E}+00$ & $0.0 E+00$ \\
\hline & & & PM-10 & Fuel burning equipment & System & 4.3E-02 & $1.8 \mathrm{E}-02$ \\
\hline & & & Sulfur oxides & Fuel burning equipment & System & $6.2 E+00$ & $2.5 \mathrm{E}+00$ \\
\hline & & & Toluene & Fuel burning equipment & System & 2.7E-04 & $1.1 \mathrm{E}-04$ \\
\hline \multirow[t]{2}{*}{ TAN } & \multirow[t]{2}{*}{679} & \multirow[t]{2}{*}{068} & VOC-methane & Fuel burning equipment & System & 2.2E-03 & $9.2 \mathrm{E}-04$ \\
\hline & & & VOC-nonmethane & Fuel burning equipment & System & 8.6E-03 & 3.5E-03 \\
\hline \multirow[t]{7}{*}{ * } & \multirow[t]{7}{*}{681} & 004 & Nitrogen oxides & Storage tank - VOC & Manually & $3.9 E-01$ & 5.0E-02 \\
\hline & & 012 & Nitrogen oxides & Chemical source & Manually & $0.0 E+00$ & $0.0 E+00$ \\
\hline & & \multirow[t]{5}{*}{023} & Carbon monoxide & Chemical source & Manually & $1.0 \mathrm{E}-01$ & 5.5E-03 \\
\hline & & & Nitrogen oxides & Chemical source & Manually & $3.0 \mathrm{E}-02$ & $1.6 E+00$ \\
\hline & & & $P M-10$ & Chemical source & Manually & 3.3E-02 & $1.8 E-03$ \\
\hline & & & Sulfur oxides & Chemical source & Manually & 2.5E-02 & 1.4E-03 \\
\hline & & & VOC-nonmethane & Chemical source & Manually & 3.0E-02 & $1.6 \mathrm{E}+\infty$ \\
\hline \multirow[t]{15}{*}{ TAN } & \multirow[t]{15}{*}{603} & \multirow[t]{5}{*}{022} & Carbon monoxide & Fuel buming equipment & System & 6.9E-01 & $0.0 E+00$ \\
\hline & & & Nitrogen oxides & Fuel burning equipment & System & 2.7E+00 & $0.0 E+00$ \\
\hline & & & PM-10 & Fuel burning equipment & System & 1.4E-01 & $0.0 E+00$ \\
\hline & & & Sulfur oxides & Fuel burning equipment & System & $2.0 E+01$ & $0.0 E+00$ \\
\hline & & & VOC-nonmethane & Fuel burning equipment & System & 2.7E-02 & $0.0 E+00$ \\
\hline & & \multirow[t]{5}{*}{027} & Carbon monoxide & Fuel burning equipment & System & 3.1E-01 & 4.6E-01 \\
\hline & & & Nitrogen oxides & Fuel burning equipment & System & $1.2 E+00$ & $1.8 E+00$ \\
\hline & & & PM-10 & Fuel burning equipment & System & $6.2 E-02$ & $9.2 \mathrm{E}-02$ \\
\hline & & & Sulfur oxides & Fuel burning equipment & System & $8.9 E+00$ & $1.3 E+01$ \\
\hline & & & VOC-nonmethane & Fuel burning equipment & System & $1.2 \mathrm{E}-02$ & $1.8 \mathrm{E}-02$ \\
\hline & & 028 & Carbon monoxide & Fuel burning equipment & System & 4.0E-01 & $4.2 E-04$ \\
\hline & & & Nitrogen oxides & Fuel burning equipment & System & $1.6 E+00$ & 1.7E-03 \\
\hline & & & PM-10 & Fuel burning equipment & System & 7.9E-02 & $8.0 E-05$ \\
\hline & & & Sulfur oxides & Fuel burning equipment & System & 1.1E+01 & $1.2 \mathrm{E}-02$ \\
\hline & & & VOC-nonmethane & Fuel burning equipment & System & $1.6 \mathrm{E}-02$ & $2.0 \mathrm{E}-05$ \\
\hline
\end{tabular}

* Not significant sources 
Table 35. (continued)

\begin{tabular}{|c|c|c|c|c|c|c|c|}
\hline \multirow[b]{2}{*}{ Area } & \multirow[b]{2}{*}{ Bldg } & \multirow[b]{2}{*}{ Vent } & \multirow[b]{2}{*}{ Pollutant } & \multirow[b]{2}{*}{ Source type } & \multirow{2}{*}{$\begin{array}{c}\text { Calc } \\
\text { method }\end{array}$} & \multicolumn{2}{|c|}{ Emissions } \\
\hline & & & & & & $\mathrm{lb} / \mathrm{hr}$ & ton/yr \\
\hline \multirow[t]{5}{*}{ TAN } & 606 & 005 & PM-10 & Chemical source & Manually & $5.6 E-02$ & $1.2 \mathrm{E}-03$ \\
\hline & & 026 & PM-10 & Chemical source & Manually & 2.2E-02 & 8.5E-04 \\
\hline & & & VOC-nonmethane & Chemical source & Manually & $1.8 \mathrm{E}-01$ & 7.3E-03 \\
\hline & & 027 & PM-10 & Chemical source & Manually & $2.2 E-02$ & 8.5E-04 \\
\hline & & & VOC-nonmethane & Chemical source & Manually & $1.8 E-01$ & 7.3E-03 \\
\hline \multirow[t]{11}{*}{ TAN } & 641 & 034 & Carbon monoxide & Fuel burning equipment & System & 2.0E-02 & 5.0E-02 \\
\hline & & & Nitrogen oxides & Fuel burning equipment & System & 8.0E-02 & 2.0E-01 \\
\hline & & & PM-10 & Fuel burning equipment & System & 4.0E-03 & $1.0 E-02$ \\
\hline & & & Sulfur oxides & Fuel burning equipment & System & 5.8E-01 & $1.4 \mathrm{E}+00$ \\
\hline & & & VOC-nonmethane & Fuel burning equipment & System & $1.4 \mathrm{E}-03$ & $3.4 \mathrm{E}-03$ \\
\hline & & 035 & Carbon monoxide & Fuel burning equipment & System & 2.0E-02 & $3.0 \mathrm{E}-05$ \\
\hline & & & Nitrogen oxides & Fuel burning equipment & System & 8.0E-02 & 1.2E-04 \\
\hline & & & PM-10 & Fuel burning equipment & System & 4.0E-03 & 1.0E-05 \\
\hline & & & Sulfur oxides & Fuel burning equipment & System & 5.8E-01 & $8.6 E-04$ \\
\hline & & & VOC-nonmethane & Fuel burning equipment & System & $1.4 E-03$ & $0.0 E+00$ \\
\hline & 677 & 030 & $P M-10$ & Chemical source & Manually & & \\
\hline * & 704 & 001 & VOC-nonmethane & Storage tank - VOC & System & $5.3 E+00$ & $1.0 \mathrm{E}+00$ \\
\hline * & 783 & 001 & VOC-nonmethane & Storage tank - VOC & System & $2.9 E \div 01$ & $5.1 E-02$ \\
\hline$*$ & 792 & 001 & VOC-nonmethane & Storage tank - VOC & System & $5.6 E+00$ & $1.4 \mathrm{E}-02$ \\
\hline${ }^{*}$ TAN & GRP & 001 & Nitrogen oxides & Chemical source & Manually & & $1.6 E+00$ \\
\hline * & & & PM-10 & Chemical source & Manually & & $6.2 \mathrm{E}-02$ \\
\hline * & & & Sulfur oxides & Chemical source & Manually & & 1.9E-01 \\
\hline$*$ & & 002 & VOC-nonmethane & Storage tank - VOC & Manually & & 1.4E-01 \\
\hline * & & 003 & PM-10 & Chemical source & Manually & & 4.4E-01 \\
\hline * & & & VOC-nonmethane & Chemical source & Manually & & 9.9E-01 \\
\hline
\end{tabular}

* Not significant sources 
Table 36. Descending rank of emissions for principle pollutants by area, building and vent.

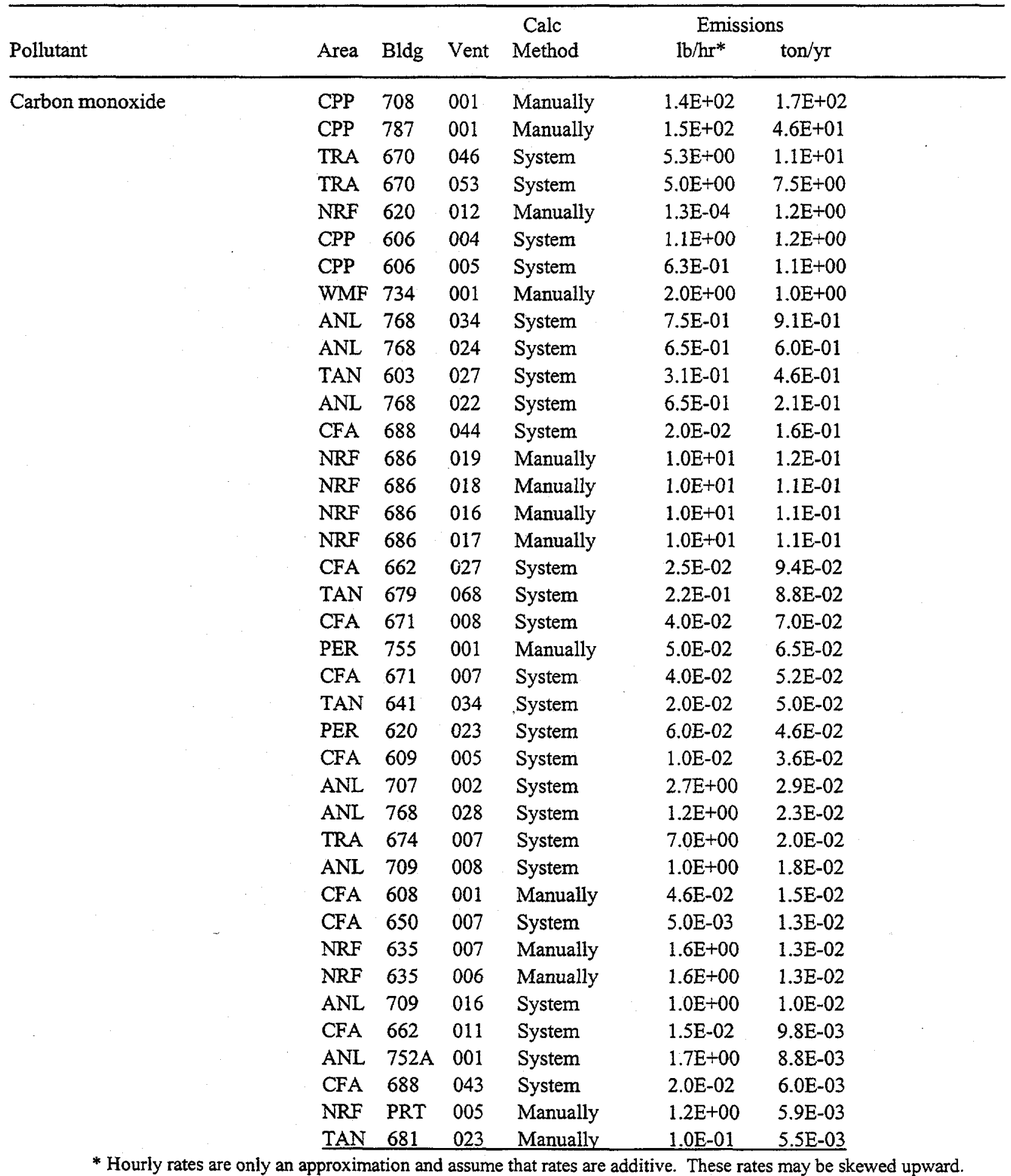


Table 36. (continued)

\begin{tabular}{|c|c|c|c|c|c|c|}
\hline \multirow[b]{2}{*}{ Pollutant } & \multirow[b]{2}{*}{ Area } & \multirow[b]{2}{*}{ Bldg } & \multirow[b]{2}{*}{ Vent } & \multirow{2}{*}{$\begin{array}{c}\text { Calc } \\
\text { Method }\end{array}$} & \multicolumn{2}{|c|}{ Emissions } \\
\hline & & & & & $\mathrm{lb} / \mathrm{hr}^{*}$ & $\operatorname{ton} / \mathrm{yr}$ \\
\hline \multirow[t]{10}{*}{ Carbon monoxide } & CFA & 104 & 001 & Manually & $1.2 \mathrm{E}-03$ & $5.1 E-03$ \\
\hline & ANL & 768 & 027 & System & $6.7 \mathrm{E}-01$ & $4.9 E-03$ \\
\hline & TAN & 603 & 028 & System & $4.0 \mathrm{E}-01$ & $4.2 \mathrm{E}-04$ \\
\hline & TAN & 679 & 067 & System & $3.0 \mathrm{E}-01$ & 1.7E-04 \\
\hline & TAN & 641 & 035 & System & $2.0 \mathrm{E}-02$ & $3.0 \mathrm{E}-05$ \\
\hline & PER & 613 & 009 & System & $2.0 \mathrm{E}-02$ & $0.0 \mathrm{E}+00$ \\
\hline & NRF & 620 & 013 & Manually & $0.0 \mathrm{E}+00$ & $0.0 \mathrm{E}+00$ \\
\hline & TAN & 603 & 022 & System & $6.9 \mathrm{E}-01$ & $0.0 \mathrm{E}+00$ \\
\hline & $\mathrm{NRF}$ & 620 & 014 & Manually & $0.0 \mathrm{E}+00$ & $0.0 \mathrm{E}+00$ \\
\hline & $\mathrm{CPP}$ & 606 & 019 & Manually & $0.0 \mathrm{E}+00$ & $0.0 \mathrm{E}+00$ \\
\hline \multirow[t]{28}{*}{ Nitrogen oxides } & $\mathrm{CPP}$ & 708 & 001 & Manually & $2.7 E+02$ & $3.4 \mathrm{E}+02$ \\
\hline & TRA & 670 & 046 & System & $2.0 \mathrm{E}+01$ & $4.1 \mathrm{E}+01$ \\
\hline & $\mathrm{CPP}$ & 787 & 001 & Manually & $1.0 \mathrm{E}+02$ & $3.4 \mathrm{E}+01$ \\
\hline & TRA & 670 & 053 & System & $1.9 \mathrm{E}+01$ & $2.8 \mathrm{E}+01$ \\
\hline & WMF & 734 & 001 & Manually & $7.7 \mathrm{E}+00$ & $1.5 \mathrm{E}+01$ \\
\hline & $\mathrm{CPP}$ & 606 & 004 & System & $4.2 \mathrm{E}+00$ & $4.7 \mathrm{E}+00$ \\
\hline & NRF & 620 & 012 & Manually & $5.3 \mathrm{E}-04$ & $4.7 \mathrm{E}+00$ \\
\hline & $\mathrm{CPP}$ & 606 & 005 & System & $2.5 \mathrm{E}+00$ & $4.5 \mathrm{E}+00$ \\
\hline & ANL & 768 & 034 & System & $3.0 \mathrm{E}+00$ & $3.6 \mathrm{E} \div 00$ \\
\hline & $\mathrm{CPP}$ & GRP & 001 & Manually & & $3.5 E \div 00$ \\
\hline & ANL & 768 & 024 & System & $2.6 \mathrm{E}+00$ & $2.4 \mathrm{E}+00$ \\
\hline & TAN & 603 & 027 & System & $1.2 \mathrm{E}+00$ & $1.8 \mathrm{E}+00$ \\
\hline & TAN & 681 & 023 & Manually & $3.0 \mathrm{E}-02$ & $1.6 \mathrm{E}+00$ \\
\hline & TAN & GRP & 001 & Manually & & $1.6 \mathrm{E}+00$ \\
\hline & PER & 755 & 001 & Manually & $1.1 E+00$ & $1.4 \mathrm{E}+00$ \\
\hline & CFA & GRP & 001 & Manually & & $1.3 E+00$ \\
\hline & TRA & GRP & 001 & Manually & & $1.1 \mathrm{E}+00$ \\
\hline & ANL & 768 & 022 & System & $2.6 \mathrm{E}+00$ & $8.4 \mathrm{E}-01$ \\
\hline & CFA & 688 & 044 & System & $8.0 \mathrm{E}-02$ & $6.5 \mathrm{E}-01$ \\
\hline & $\mathrm{CPP}$ & 637 & 058 & Manually & $9.4 \mathrm{E}+00$ & $4.8 \mathrm{E}-01$ \\
\hline & NRF & 686 & 019 & Manually & $3.9 \mathrm{E}+01$ & 4.4E-01 \\
\hline & NRF & 686 & 017 & Manually & $3.9 E+01$ & 4.3E-01 \\
\hline & NRF & 686 & 016 & Manually & $3.9 E+01$ & 4.2E-01 \\
\hline & NRF & 686 & 018 & Manually & $3.9 \mathrm{E}+01$ & 4.1E-01 \\
\hline & CFA & 662 & 027 & System & $1.0 \mathrm{E}-01$ & $3.8 \mathrm{E}-01$ \\
\hline & WMF & GRP & 001 & Manually & & $3.6 \mathrm{E}-01$ \\
\hline & TAN & 679 & 068 & System & $8.6 \mathrm{E}-01$ & $3.5 \mathrm{E}-01$ \\
\hline & CFA & 671 & 008 & System & $1.6 \mathrm{E}-01$ & $2.8 \mathrm{E}-01$ \\
\hline
\end{tabular}

* Hourly rates are only an approximation and assume that rates are additive. These rates may be skewed upward. 
Table 36. (continued)

\begin{tabular}{|c|c|c|c|c|c|c|}
\hline \multirow[b]{2}{*}{ Pollutant } & \multirow[b]{2}{*}{ Area } & \multirow[b]{2}{*}{ Bldg } & \multirow[b]{2}{*}{ Vent } & \multirow{2}{*}{$\begin{array}{c}\text { Calc } \\
\text { Method }\end{array}$} & \multicolumn{2}{|c|}{ Emissions } \\
\hline & & & & & $\mathrm{lb} / \mathrm{hr}^{*}$ & ton/yr \\
\hline \multirow[t]{34}{*}{ Nitrogen oxides } & PER & GRP & 001 & Manually & & $2.4 E-01$ \\
\hline & CFA & 671 & 007 & System & $1.6 \mathrm{E}-01$ & $2.1 \mathrm{E}-01$ \\
\hline & TAN & 641 & 034 & System & $8.0 \mathrm{E}-02$ & $2.0 \mathrm{E}-01$ \\
\hline & CPP & 637 & 032 & Manually & $2.3 E+00$ & $2.0 \mathrm{E}-01$ \\
\hline & PER & 620 & 023 & System & $2.4 \mathrm{E}-01$ & $1.9 \mathrm{E}-01$ \\
\hline & CFA & 609 & 005 & System & $4.0 \mathrm{E}-02$ & $1.4 \mathrm{E}-01$ \\
\hline & ANL & 707 & 002 & System & $1.2 \mathrm{E}+01$ & $1.3 \mathrm{E}-01$ \\
\hline & ANL & 768 & 028 & System & $5.4 \mathrm{E}+00$ & 1.0E-01 \\
\hline & TRA & 674 & 007 & System & $2.6 \mathrm{E}+01$ & $7.7 E-02$ \\
\hline & ANL & 709 & 008 & System & $3.9 E+00$ & $6.9 E-02$ \\
\hline & NRF & 635 & 006 & Manually & $7.6 \mathrm{E}+00$ & $6.0 \mathrm{E}-02$ \\
\hline & CFA & 608 & 001 & Manually & $1.8 \mathrm{E}-02$ & $6.0 \mathrm{E}-02$ \\
\hline & NRF & 635 & 007 & Manually & $7.6 \mathrm{E}+00$ & $6.0 E-02$ \\
\hline & CFA & 650 & 007 & System & $2.0 \mathrm{E}-02$ & $5.3 \mathrm{E}-02$ \\
\hline & TAN & 681 & 004 & Manually & $3.9 \mathrm{E}-01$ & $5.0 \mathrm{E}-02$ \\
\hline & ANL & $752 \mathrm{~A}$ & 001 & System & $7.9 \mathrm{E}+00$ & $4.0 \mathrm{E}-02$ \\
\hline & CFA & 662 & 011 & System & $6.0 \mathrm{E}-02$ & $3.9 \mathrm{E}-02$ \\
\hline & ANL & 709 & 016 & System & $3.9 \mathrm{E}+00$ & $3.9 \mathrm{E}-02$ \\
\hline & PER & 612 & 006 & Manually & & $3.1 \mathrm{E}-02$ \\
\hline & NRF & PRT & 005 & Manually & $5.5 E+00$ & $2.7 \mathrm{E}-02$ \\
\hline & CFA & 688 & 043 & System & $8.0 \mathrm{E}-02$ & $2.4 \mathrm{E}-02$ \\
\hline & PER & 601 & 010 & Manually & & $2.0 \mathrm{E}-02$ \\
\hline & ANL & 768 & 027 & System & $2.7 \mathrm{E}+00$ & $2.0 \mathrm{E}-02$ \\
\hline & PER & 632 & 007 & Manually & & $9.8 \mathrm{E}-03$ \\
\hline & PER & $601 \mathrm{~A}$ & 010 & Manually & & $3.6 \mathrm{E}-03$ \\
\hline & TAN & 603 & 028 & System & $1.6 \mathrm{E}+00$ & $1.7 \mathrm{E}-03$ \\
\hline & TAN & 679 & 067 & System & $1.2 \mathrm{E}+00$ & $6.8 \mathrm{E}-04$ \\
\hline & TAN & 641 & 035 & System & $8.0 \mathrm{E}-02$ & $1.2 \mathrm{E}-04$ \\
\hline & NRF & 620 & 014 & Manually & $0.0 \mathrm{E}+00$ & $0.0 \mathrm{E}+00$ \\
\hline & NRF & 620 & 013 & Manually & $0.0 \mathrm{E}+00$ & $0.0 E+00$ \\
\hline & PER & 613 & 009 & System & $8.0 \mathrm{E}-02$ & $0.0 \mathrm{E}+00$ \\
\hline & $\mathrm{CPP}$ & 606 & 019 & Manually & $0.0 \mathrm{E}+00$ & $0.0 \mathrm{E}+00$ \\
\hline & TAN & 603 & 022 & System & $2.7 \mathrm{E}+00$ & $0.0 \mathrm{E}+00$ \\
\hline & TAN & 681 & 012 & Manually & $0.0 \mathrm{E}+00$ & $0.0 \mathrm{E}+00$ \\
\hline \multirow[t]{3}{*}{$\mathrm{PM}-10$} & CFA & 104 & 001 & Manually & $3.8 \mathrm{E}+01$ & $3.8 \mathrm{E}+01$ \\
\hline & CFA & 623 & 007 & Manually & $3.0 \mathrm{E}+00$ & $3.0 \mathrm{E}+00$ \\
\hline & TRA & 771 & 001 & Manually & $9.0 \mathrm{E}-01$ & $2.3 E+00$ \\
\hline
\end{tabular}

* Hourly rates are only an approximation and assume that rates are additive. These rates may be skewed upward. 
Table 36. (continued)

\begin{tabular}{|c|c|c|c|c|c|c|}
\hline \multirow[b]{2}{*}{ Pollutant } & \multirow[b]{2}{*}{ Area } & \multirow[b]{2}{*}{ Bldg } & \multirow[b]{2}{*}{ Vent } & \multirow{2}{*}{$\begin{array}{l}\text { Calc } \\
\text { Method }\end{array}$} & \multicolumn{2}{|c|}{ Emissions } \\
\hline & & & & & $\mathrm{lb} / \mathrm{hr} *$ & $\operatorname{ton} / \mathrm{yr}$ \\
\hline \multirow[t]{37}{*}{ PM-10 } & WMF & 734 & 001 & Manually & $2.4 \mathrm{E}-01$ & $1.0 \mathrm{E}+00$ \\
\hline & TRA & 670 & 046 & System & 3.7E-01 & $7.5 \mathrm{E}-01$ \\
\hline & NRF & 620 & 012 & Manually & $6.0 \mathrm{E}-05$ & $5.4 \mathrm{E}-01$ \\
\hline & TRA & 670 & 053 & System & $3.4 \mathrm{E}-01$ & $5.2 \mathrm{E}-01$ \\
\hline & $\mathrm{CFA}$ & GRP & 003 & Manually & & $4.9 E-01$ \\
\hline & $\mathrm{CPP}$ & GRP & 003 & Manually & & $4.9 \mathrm{E}-01$ \\
\hline & TAN & GRP & 003 & Manually & & $4.4 \mathrm{E}-01$ \\
\hline & CPP & 787 & 001 & Manually & $0.0 \mathrm{E}+00$ & 4.1E-01 \\
\hline & TRA & GRP & 003 & Manually & & $3.3 \mathrm{E}-01$ \\
\hline & $\mathrm{CPP}$ & 606 & 004 & System & $2.1 \mathrm{E}-01$ & $2.4 \mathrm{E}-01$ \\
\hline & CPP & 606 & 005 & System & $1.3 \mathrm{E}-01$ & $2.2 \mathrm{E}-01$ \\
\hline & ANL & 768 & 034 & System & $1.5 \mathrm{E}-01$ & $1.8 \mathrm{E}-01$ \\
\hline & WMF & 656 & 001 & Manually & $1.6 \mathrm{E}-01$ & $1.6 \mathrm{E}-01$ \\
\hline & TAN & 629 & 012 & Manually & $2.8 \mathrm{E}-04$ & $1.6 \mathrm{E}-01$ \\
\hline & CPP & 653 & 001 & Manually & $2.8 \mathrm{E}-01$ & $1.5 \mathrm{E}-01$ \\
\hline & ANL & 768 & 024 & System & $1.3 \mathrm{E}-01$ & $1.2 \mathrm{E}-01$ \\
\hline & CPP & GRP & 001 & Manually & & $1.0 \mathrm{E}-01$ \\
\hline & TAN & 603 & 027 & System & $6.2 \mathrm{E}-02$ & $9.2 \mathrm{E}-02$ \\
\hline & TRA & GRP & 001 & Manually & & $7.5 \mathrm{E}-02$ \\
\hline & TAN & GRP & 001 & Manually & & $6.2 \mathrm{E}-02$ \\
\hline & $\mathrm{CFA}$ & GRP & 001 & Manually & & $6.2 \mathrm{E}-02$ \\
\hline & ANL & 768 & 022 & System & 1.3E-01 & $4.2 \mathrm{E}-02$ \\
\hline & PER & 755 & 001 & Manually & $2.8 \mathrm{E}-02$ & $3.6 \mathrm{E}-02$ \\
\hline & $\mathrm{CFA}$ & 688 & 044 & System & $4.0 \mathrm{E}-03$ & $3.3 \mathrm{E}-02$ \\
\hline & $\mathrm{CPP}$ & 794 & 001 & Manually & $1.1 E+00$ & $2.8 \mathrm{E}-02$ \\
\hline & CFA & 662 & 027 & System & $5.0 \mathrm{E}-03$ & $1.9 \mathrm{E}-02$ \\
\hline & TAN & 679 & 068 & System & $4.3 \mathrm{E}-02$ & $1.8 \mathrm{E}-02$ \\
\hline & PER & GRP & 001 & Manually & & $1.7 \mathrm{E}-02$ \\
\hline & WMF & GRP & 001 & Manually & & $1.4 \mathrm{E}-02$ \\
\hline & CFA & 671 & 008 & System & $8.0 \mathrm{E}-03$ & $1.4 \mathrm{E}-02$ \\
\hline & $\mathrm{CFA}$ & 671 & 007 & System & $8.0 \mathrm{E}-03$ & $1.0 \mathrm{E}-02$ \\
\hline & TAN & 641 & 034 & System & $4.0 \mathrm{E}-03$ & $1.0 \mathrm{E}-02$ \\
\hline & PER & 620 & 023 & System & $1.2 \mathrm{E}-02$ & $9.3 \mathrm{E}-03$ \\
\hline & ANL & 707 & 002 & System & $8.4 \mathrm{E}-01$ & $9.2 \mathrm{E}-03$ \\
\hline & NRF & 686 & 019 & Manually & $7.1 \mathrm{E}-01$ & $7.9 \mathrm{E}-03$ \\
\hline & CPP & 792 & 001 & Manually & $2.5 \mathrm{E}-02$ & $7.7 \mathrm{E}-03$ \\
\hline & NRF & 686 & 017 & Manually & $7.1 \mathrm{E}-01$ & $7.7 \mathrm{E}-03$ \\
\hline
\end{tabular}

* Hourly rates are only an approximation and assume that rates are additive. These rates may be skewed upward. 
Table 36. (continued)

\begin{tabular}{|c|c|c|c|c|c|c|}
\hline \multirow{2}{*}{ Pollutant } & \multirow[b]{2}{*}{ Area } & \multirow[b]{2}{*}{ Bldg } & \multirow[b]{2}{*}{ Vent } & \multirow{2}{*}{$\begin{array}{l}\text { Calc } \\
\text { Method }\end{array}$} & \multicolumn{2}{|c|}{ Emissions } \\
\hline & & & & & $\mathrm{lb} / \mathrm{hr}^{*}$ & ton/yr \\
\hline \multirow[t]{38}{*}{ PM-10 } & NRF & 686 & 016 & Manually & 7.1E-01 & $7.6 \mathrm{E}-03$ \\
\hline & NRF & 686 & 018 & Manually & $7.1 \mathrm{E}-01$ & 7.4E-03 \\
\hline & ANL & 768 & 028 & System & $3.8 \mathrm{E}-01$ & 7.3E-03 \\
\hline & CFA & 609 & 005 & System & $2.0 \mathrm{E}-03$ & $7.1 \mathrm{E}-03$ \\
\hline & CPP & 687 & 033 & Manually & $1.9 \mathrm{E}-02$ & $5.9 \mathrm{E}-03$ \\
\hline & $\mathrm{CPP}$ & 793 & 002 & Manually & $2.0 \mathrm{E}-01$ & $5.9 \mathrm{E}-03$ \\
\hline & CPP & 687 & 034 & Manually & $1.9 \mathrm{E}-02$ & $5.9 \mathrm{E}-03$ \\
\hline & CPP & 025 & 001 & Manually & $2.0 \mathrm{E}-01$ & $4.9 \mathrm{E}-03$ \\
\hline & NRF & 635 & 006 & Manually & 5.3E-01 & $4.2 \mathrm{E}-03$ \\
\hline & $\mathrm{NRF}$ & 635 & 007 & Manually & $5.3 \mathrm{E}-01$ & 4.2E-03 \\
\hline & $\mathrm{CFA}$ & 608 & 001 & Manually & $9.9 \mathrm{E}-04$ & $3.3 \mathrm{E}-03$ \\
\hline & ANL & $752 \mathrm{~A}$ & 001 & System & $5.5 \mathrm{E}-01$ & $2.7 \mathrm{E}-03$ \\
\hline & CFA & 650 & 007 & System & $1.0 \mathrm{E}-03$ & 2.7E-03 \\
\hline & CFA & 662 & 011 & System & $3.0 \mathrm{E}-03$ & $2.0 \mathrm{E}-03$ \\
\hline & TAN & 629 & 002 & Manually & $1.0 \mathrm{E}-01$ & $1.9 \mathrm{E}-03$ \\
\hline & NRF & PRT & 005 & Manually & $3.9 \mathrm{E}-01$ & $1.9 \mathrm{E}-03$ \\
\hline & TAN & 681 & 023 & Manually & 3.3E-02 & $1.8 \mathrm{E}-03$ \\
\hline & TRA & 674 & 007 & System & $4.8 \mathrm{E}-01$ & $1.4 \mathrm{E}-03$ \\
\hline & ANL & 709 & 008 & System & $7.2 \mathrm{E}-02$ & $1.3 \mathrm{E}-03$ \\
\hline & CFA & 688 & 043 & System & $4.0 \mathrm{E}-03$ & $1.2 \mathrm{E}-03$ \\
\hline & TAN & 606 & 005 & Manually & $5.6 \mathrm{E}-02$ & 1.2E-03 \\
\hline & ANL & 768 & 027 & System & $1.3 \mathrm{E}-01$ & $9.8 \mathrm{E}-04$ \\
\hline & TAN & 606 & 027 & Manually & $2.2 \mathrm{E}-02$ & $8.5 \mathrm{E}-04$ \\
\hline & TAN & 606 & 026 & Manually & $2.2 \mathrm{E}-02$ & $8.5 \mathrm{E}-04$ \\
\hline & ANL & 709 & 016 & System & 7.2E-02 & $7.0 \mathrm{E}-04$ \\
\hline & PER & 612 & 006 & Manually & & $6.9 \mathrm{E}-04$ \\
\hline & CPP & 687 & 010 & Manually & 1.7E-03 & $5.0 \mathrm{E}-04$ \\
\hline & $\mathrm{CPP}$ & 687 & 011 & Manually & $1.7 \mathrm{E}-03$ & $5.0 \mathrm{E}-04$ \\
\hline & PER & 601 & 010 & Manually & & $4.3 \mathrm{E}-04$ \\
\hline & CPP & 792 & 003 & Manually & 8.0E-04 & 4.0E-04 \\
\hline & CPP & 792 & 002 & Manually & $8.0 \mathrm{E}-04$ & $4.0 \mathrm{E}-04$ \\
\hline & PER & 632 & 007 & Manually & & 2.1E-04 \\
\hline & TAN & 607 & 041 & Manually & $3.2 \mathrm{E}-04$ & $1.9 E-04$ \\
\hline & PER & $601 A$ & 010 & Manually & & $8.0 \mathrm{E}-05$ \\
\hline & TAN & 607 & 039 & Manually & 3.0E-05 & $8.0 \mathrm{E}-05$ \\
\hline & TAN & 603 & 028 & System & $7.9 \mathrm{E}-02$ & $8.0 \mathrm{E}-05$ \\
\hline & TAN & 679 & 067 & System & $6.0 \mathrm{E}-02$ & $3.0 \mathrm{E}-05$ \\
\hline & TAN & 641 & 035 & System & $4.0 \mathrm{E}-03$ & $1.0 \mathrm{E}-05$ \\
\hline
\end{tabular}

* Hourly rates are only an approximation and assume that rates are additive. These rates may be skewed upward. 
Table 36. (continued)

\begin{tabular}{|c|c|c|c|c|c|c|}
\hline \multirow[b]{2}{*}{ Pollutant } & \multirow[b]{2}{*}{ Area } & \multirow[b]{2}{*}{ Bldg } & \multirow[b]{2}{*}{ Vent } & \multirow{2}{*}{$\begin{array}{c}\text { Calc } \\
\text { Method }\end{array}$} & \multicolumn{2}{|c|}{ Emissions } \\
\hline & & & & & $\mathrm{lb} / \mathrm{hr} *$ & $\operatorname{ton} / \mathrm{yr}$ \\
\hline \multirow[t]{8}{*}{ PM-10 } & $\mathrm{NRF}$ & 620 & 014 & Manually & $0.0 \mathrm{E}+00$ & $0.0 \mathrm{E}+00$ \\
\hline & TAN & 603 & 022 & System & $1.4 \mathrm{E}-01$ & $0.0 \mathrm{E}+00$ \\
\hline & NRF & 620 & 013 & Manually & $0.0 \mathrm{E}+00$ & $0.0 \mathrm{E}+00$ \\
\hline & ANL & 753 & 029 & Manually & $1.2 \mathrm{E}-03$ & $0.0 \mathrm{E}+00$ \\
\hline & $\mathrm{CPP}$ & 606 & 019 & Manually & $0.0 \mathrm{E}+00$ & $0.0 \mathrm{E}+00$ \\
\hline & $\mathrm{CPP}$ & 637 & 058 & Manually & $0.0 \mathrm{E}+00$ & $0.0 \mathrm{E}+00$ \\
\hline & PER & 613 & 009 & System & $4.0 \mathrm{E}-03$ & $0.0 \mathrm{E}+00$ \\
\hline & $\mathrm{CPP}$ & 637 & 032 & Manually & $0.0 \mathrm{E}+00$ & $0.0 \mathrm{E}+00$ \\
\hline \multirow[t]{28}{*}{ Sulfur oxides } & CPP & 606 & 004 & System & $3.0 \mathrm{E}+01$ & $3.4 \mathrm{E}+01$ \\
\hline & $\mathrm{CPP}$ & 606 & 005 & System & $1.8 \mathrm{E}+01$ & $3.2 \mathrm{E}+01$ \\
\hline & ANL & 768 & 034 & System & $2.2 \mathrm{E}+01$ & $2.6 \mathrm{E}+01$ \\
\hline & ANL & 768 & 024 & System & $1.9 \mathrm{E}+01$ & $1.7 E+01$ \\
\hline & TAN & 603 & 027 & System & $8.9 E+00$ & $1.3 E+01$ \\
\hline & $\mathrm{CPP}$ & 787 & 001 & Manually & $8.8 \mathrm{E}+01$ & $7.0 E+00$ \\
\hline & TRA & 670 & 046 & System & $3.2 \mathrm{E}+00$ & $6.5 \mathrm{E}+00$ \\
\hline & ANL & 768 & 022 & System & $1.9 \mathrm{E}+01$ & $6.1 \mathrm{E}+00$ \\
\hline & NRF & 620 & 012 & Manually & $6.2 \mathrm{E}-04$ & $5.4 \mathrm{E}+00$ \\
\hline & CFA & 688 & 044 & System & $5.8 \mathrm{E}-01$ & $4.7 \mathrm{E}+00$ \\
\hline & TRA & 670 & 053 & System & $3.0 \mathrm{E}+00$ & $4.5 \mathrm{E}+00$ \\
\hline & WMF & 734 & 001 & Manually & $1.5 \mathrm{E}+00$ & $3.0 \mathrm{E}+00$ \\
\hline & CPP & 708 & 001 & Manually & $2.4 \mathrm{E}+00$ & $3.0 \mathrm{E}+00$ \\
\hline & CFA & 662 & 027 & System & $7.2 \mathrm{E}-01$ & $2.7 \mathrm{E}+00$ \\
\hline & TAN & 679 & 068 & System & $6.2 \mathrm{E}+00$ & $2.5 \mathrm{E}+00$ \\
\hline & $\mathrm{CFA}$ & 671 & 008 & System & $1.2 \mathrm{E}+00$ & $2.0 \mathrm{E}+00$ \\
\hline & CFA & 671 & 007 & System & $1.2 \mathrm{E}+00$ & $1.5 E+00$ \\
\hline & TAN & 641 & 034 & System & $5.8 \mathrm{E}-01$ & $1.4 \mathrm{E}+00$ \\
\hline & PER & 620 & 023 & System & $1.7 \mathrm{E}+00$ & $1.3 \mathrm{E}+00$ \\
\hline & PER & 755 & 001 & Manually & $1.0 \mathrm{E}+00$ & $1.3 \mathrm{E}+00$ \\
\hline & CFA & 609 & 005 & System & $2.9 \mathrm{E}-01$ & $1.0 \mathrm{E}+00$ \\
\hline & $\mathrm{CPP}$ & GRP & 001 & Manually & & $4.3 \mathrm{E}-01$ \\
\hline & CFA & 650 & 007 & System & $1.4 \mathrm{E}-01$ & $3.8 \mathrm{E}-01$ \\
\hline & CFA & 662 & 011 & System & 4.3E-01 & $2.8 \mathrm{E}-01$ \\
\hline & CFA & 608 & 001 & Manually & $6.5 \mathrm{E}-02$ & 2.1E-01 \\
\hline & TAN & GRP & 001 & Manually & & $1.9 \mathrm{E}-01$ \\
\hline & CFA & 688 & 043 & System & $5.8 \mathrm{E}-01$ & 1.7E-01 \\
\hline & ANL & 768 & 027 & System & $1.9 \mathrm{E}+01$ & $1.4 \mathrm{E}-01$ \\
\hline
\end{tabular}

* Hourly rates are only an approximation and assume that rates are additive. These rates may be skewed upward. 
Table 36. (continued)

\begin{tabular}{|c|c|c|c|c|c|c|}
\hline \multirow[b]{2}{*}{ Pollutant } & \multirow[b]{2}{*}{ Area } & \multirow[b]{2}{*}{ Bldg } & \multirow[b]{2}{*}{ Vent } & \multirow{2}{*}{$\begin{array}{l}\text { Calc } \\
\text { Method }\end{array}$} & \multicolumn{2}{|c|}{ Emissions } \\
\hline & & & & & $\mathrm{lb} / \mathrm{hr} *$ & ton/yr \\
\hline \multirow[t]{32}{*}{ Sulfur oxides } & PER & 601 & 010 & Manually & & $8.0 \mathrm{E}-02$ \\
\hline & TRA & GRP & 001 & Manually & & $7.0 \mathrm{E}-02$ \\
\hline & CFA & GRP & 001 & Manually & & 4.5E-02 \\
\hline & PER & 632 & 007 & Manually & & 4.0E-02 \\
\hline & PER & 612 & 006 & Manually & & $3.1 \mathrm{E}-02$ \\
\hline & PER & GRP & 001 & Manually & & $1.5 \mathrm{E}-02$ \\
\hline & PER & $601 \mathrm{~A}$ & 010 & Manually & & $.5 \mathrm{E}-02$ \\
\hline & TAN & 603 & 028 & System & $1.1 \mathrm{E}+01$ & $1.2 \mathrm{E}-02$ \\
\hline & TRA & 674 & 007 & System & $4.1 \mathrm{E}+00$ & $1.2 \mathrm{E}-02$ \\
\hline & ANL & 709 & 008 & System & $6.2 \mathrm{E}-01$ & $1.1 \mathrm{E}-02$ \\
\hline & ANL & 707 & 002 & System & $8.0 \mathrm{E}-01$ & $8.7 \mathrm{E}-03$ \\
\hline & WMF & GRP & 001 & Manually & & $8.0 \mathrm{E}-03$ \\
\hline & ANL & 768 & 028 & System & $3.6 \mathrm{E}-01$ & $6.9 \mathrm{E}-03$ \\
\hline & NRF & 686 & 019 & Manually & $5.6 \mathrm{E}-01$ & $6.2 \mathrm{E}-03$ \\
\hline & NRF & 686 & 017 & Manually & $5.6 \mathrm{E}-01$ & $6.1 \mathrm{E}-03$ \\
\hline & ANL & 709 & 016 & System & $6.2 \mathrm{E}-01$ & $6.1 \mathrm{E}-03$ \\
\hline & NRF & 686 & 016 & Manually & $5.6 \mathrm{E}-01$ & $6.0 \mathrm{E}-03$ \\
\hline & NRF & 686 & 018 & Manually & $5.6 \mathrm{E}-01$ & $5.9 \mathrm{E}-03$ \\
\hline & TAN & 679 & 067 & System & $8.6 \mathrm{E}+00$ & $4.9 \mathrm{E}-03$ \\
\hline & NRF & 635 & 007 & Manually & $5.0 \mathrm{E}-01$ & $4.0 \mathrm{E}-03$ \\
\hline & NRF & 635 & 006 & Manually & $5.0 \mathrm{E}-01$ & $4.0 \mathrm{E}-03$ \\
\hline & ANL & $752 \mathrm{~A}$ & 001 & System & $5.2 \mathrm{E}-01$ & $2.6 \mathrm{E}-03$ \\
\hline & NRF & PRT & 005 & Manually & $3.6 \mathrm{E}-01$ & $1.8 \mathrm{E}-03$ \\
\hline & TAN & 681 & 023 & Manually & $2.5 \mathrm{E}-02$ & $1.4 \mathrm{E}-03$ \\
\hline & TAN & 641 & 035 & System & $5.8 \mathrm{E}-01$ & $8.6 \mathrm{E}-04$ \\
\hline & CPP & 637 & 032 & Manually & $2.6 \mathrm{E}-03$ & $6.5 \mathrm{E}-04$ \\
\hline & $\mathrm{CPP}$ & 637 & 058 & Manually & $5.8 \mathrm{E}-03$ & $2.9 E-04$ \\
\hline & NRF & 620 & 014 & Manually & $0.0 \mathrm{E}+00$ & $0.0 \mathrm{E}+00$ \\
\hline & NRF & 620 & 013 & Manually & $0.0 \mathrm{E}+00$ & $0.0 \mathrm{E}+00$ \\
\hline & $\mathrm{CPP}$ & 606 & 019 & Manually & $0.0 \mathrm{E}+00$ & $0.0 E+00$ \\
\hline & TAN & 603 & 022 & System & $2.0 \mathrm{E}+01$ & $0.0 \mathrm{E}+00$ \\
\hline & PER & 613 & 009 & System & $5.8 \mathrm{E}-01$ & $0.0 \mathrm{E}+00$ \\
\hline
\end{tabular}

* Hourly rates are only an approximation and assume that rates are additive. These rates may be skewed upward. 
Table 36. (continued)

\begin{tabular}{|c|c|c|c|c|c|c|}
\hline Pollutant & Area & Bldg & Vent & $\begin{array}{l}\text { Calc } \\
\text { Method }\end{array}$ & \multicolumn{2}{|c|}{ Emissions } \\
\hline \multirow[t]{38}{*}{ VOC-nonmethane } & CPP & 708 & 001 & Manually & $9.2 \mathrm{E}+00$ & $1.2 \mathrm{E}+01$ \\
\hline & WMF & $628-63$ & 001 & Manually & $2.1 \mathrm{E}+02$ & $5.4 \mathrm{E}+00$ \\
\hline & $\mathrm{CPP}$ & GRP & 003 & Manually & & $1.6 \mathrm{E}+00$ \\
\hline & TAN & 681 & 023 & Manually & $3.0 \mathrm{E}-02$ & $1.6 \mathrm{E}+00$ \\
\hline & ANL & $755 \mathrm{~A}$ & 001 & System & $1.1 E+01$ & $1.4 \mathrm{E}+00$ \\
\hline & CFA & GRP & 003 & Manually & & $1.2 \mathrm{E}+00$ \\
\hline & TRA & GRP & 003 & Manually & & $1.2 \mathrm{E}+00$ \\
\hline & TAN & 704 & 001 & System & $5.3 \mathrm{E}+00$ & $1.0 \mathrm{E}+00$ \\
\hline & TRA & 670 & 046 & System & $5.1 \mathrm{E}-01$ & $1.0 \mathrm{E}+00$ \\
\hline & TAN & GRP & 003 & Manually & & $9.9 E-01$ \\
\hline & TRA & 670 & 053 & System & 4.7E-01 & $7.2 \mathrm{E}-01$ \\
\hline & ANL & $755 \mathrm{~B}$ & 002 & System & $1.1 \mathrm{E}+01$ & $5.0 \mathrm{E}-01$ \\
\hline & $\mathrm{CPP}$ & 663 & 131 & Manually & $3.2 \mathrm{E}-01$ & $4.4 \mathrm{E}-01$ \\
\hline & CFA & 104 & 001 & Manually & $6.1 \mathrm{E}-02$ & $2.7 \mathrm{E}-01$ \\
\hline & TAN & GRP & 002 & Manually & & $1.4 \mathrm{E}-01$ \\
\hline & CPP & 787 & 001 & Manually & $4.0 \mathrm{E}-01$ & $1.3 \mathrm{E}-01$ \\
\hline & $\mathrm{CPP}$ & GRP & 002 & Manually & & $1.2 \mathrm{E}-01$ \\
\hline & CFA & GRP & 002 & Manually & & $1.0 \mathrm{E}-01$ \\
\hline & TAN & 629 & 012 & Manually & $2.0 \mathrm{E}+00$ & 7.7E-02 \\
\hline & TRA & GRP & 002 & Manually & & $5.6 \mathrm{E}-02$ \\
\hline & TAN & 783 & 001 & System & $2.9 \mathrm{E}+01$ & $5.1 \mathrm{E}-02$ \\
\hline & CPP & 606 & 004 & System & $4.2 \mathrm{E}-02$ & $4.7 \mathrm{E}-02$ \\
\hline & NRF & 620 & 012 & Manually & $1.0 \mathrm{E}-05$ & 4.7E-02 \\
\hline & $\mathrm{CPP}$ & 606 & 005 & System & $2.5 \mathrm{E}-02$ & 4.5E-02 \\
\hline & ANL & 768 & 034 & System & $3.0 \mathrm{E}-02$ & $3.6 \mathrm{E}-02$ \\
\hline & ANL & 768 & 024 & System & $2.6 \mathrm{E}-02$ & $2.4 \mathrm{E}-02$ \\
\hline & CPP & 663 & 130 & Manually & $3.2 \mathrm{E}-01$ & 2.4E-02 \\
\hline & TAN & 603 & 027 & System & $1.2 \mathrm{E}-02$ & $1.8 \mathrm{E}-02$ \\
\hline & NRF & 773 & 001 & Manually & $3.9 \mathrm{E}-03$ & $1.7 \mathrm{E}-02$ \\
\hline & TAN & 792 & 001 & System & $5.6 \mathrm{E}+00$ & $1.4 \mathrm{E}-02$ \\
\hline & PER & GRP & 002 & Manually & & $1.3 \mathrm{E}-02$ \\
\hline & ANL & 707 & 002 & System & $8.8 \mathrm{E}-01$ & $9.6 \mathrm{E}-03$ \\
\hline & PER & 722 & 001 & System & $0.0 \mathrm{E}+00$ & 8.7E-03 \\
\hline & ANL & 768 & 022 & System & $2.6 \mathrm{E}-02$ & 8.4E-03 \\
\hline & ANL & 768 & 028 & System & $4.0 \mathrm{E}-01$ & $7.6 \mathrm{E}-03$ \\
\hline & TAN & 606 & 026 & Manually & $1.8 \mathrm{E}-01$ & 7.3E-03 \\
\hline & TAN & 606 & 027 & Manually & $1.8 \mathrm{E}-01$ & 7.3E-03 \\
\hline & CFA & 688 & 044 & System & $8.0 \mathrm{E}-04$ & $6.5 \mathrm{E}-03$ \\
\hline
\end{tabular}

* Hourly rates are only an approximation and assume that rates are additive. These rates may be skewed upward. 
Table 36. (continued)

\begin{tabular}{|c|c|c|c|c|c|c|}
\hline \multirow[b]{2}{*}{ Pollutant } & \multirow[b]{2}{*}{ Area } & \multirow[b]{2}{*}{ Bldg } & \multirow[b]{2}{*}{ Vent } & \multirow{2}{*}{$\begin{array}{l}\text { Calc } \\
\text { Method }\end{array}$} & \multicolumn{2}{|c|}{ Emissions } \\
\hline & & & & & $\mathrm{lb} / \mathrm{hr} *$ & $\operatorname{ton} / \mathrm{yr}$ \\
\hline \multirow[t]{39}{*}{ VOC-nonmethane } & CFA & 662 & 027 & System & $1.7 \mathrm{E}-03$ & $6.4 \mathrm{E}-03$ \\
\hline & $\mathrm{NRF}$ & $759 \mathrm{~A}$ & 001 & Manually & $1.4 \mathrm{E}-03$ & $6.2 \mathrm{E}-03$ \\
\hline & CFA & 671 & 008 & System & $2.7 \mathrm{E}-03$ & $4.8 \mathrm{E}-03$ \\
\hline & NRF & 635 & 006 & Manually & $5.6 \mathrm{E}-01$ & $4.5 E-03$ \\
\hline & NRF & 635 & 007 & Manually & $5.6 \mathrm{E}-01$ & $4.5 \mathrm{E}-03$ \\
\hline & TAN & 679 & 068 & System & $8.6 \mathrm{E}-03$ & $3.5 E-03$ \\
\hline & CFA & 671 & 007 & System & $2.7 \mathrm{E}-03$ & $3.5 \mathrm{E}-03$ \\
\hline & TAN & 607 & 119 & Manually & $3.4 \mathrm{E}-03$ & $3.5 \mathrm{E}-03$ \\
\hline & TAN & 641 & 034 & System & $1.4 \mathrm{E}-03$ & $3.4 \mathrm{E}-03$ \\
\hline & PER & 620 & 023 & System & 4.1E-03 & $3.2 \mathrm{E}-03$ \\
\hline & ANL & $752 \mathrm{~A}$ & 001 & System & $5.7 \mathrm{E}-01$ & $2.9 \mathrm{E}-03$ \\
\hline & WMF & 734 & 001 & Manually & $2.0 \mathrm{E}-01$ & $2.6 \mathrm{E}-03$ \\
\hline & CFA & 609 & 005 & System & $6.8 \mathrm{E}-04$ & $2.4 \mathrm{E}-03$ \\
\hline & NRF & PRT & 005 & Manually & 4.1E-01 & $2.0 \mathrm{E}-03$ \\
\hline & TRA & 674 & 007 & System & $6.6 \mathrm{E}-01$ & $1.9 E-03$ \\
\hline & ANL & 709 & 008 & System & $9.9 \mathrm{E}-02$ & $1.7 \mathrm{E}-03$ \\
\hline & CFA & 608 & 001 & Manually & $3.1 \mathrm{E}-04$ & $1.0 \mathrm{E}-03$ \\
\hline & ANL & 709 & 016 & System & $9.9 E-02$ & $9.7 \mathrm{E}-04$ \\
\hline & CFA & 650 & 007 & System & $3.4 \mathrm{E}-04$ & $9.1 \mathrm{E}-04$ \\
\hline & PER & 755 & 001 & Manually & $5.9 \mathrm{E}-04$ & $7.6 \mathrm{E}-04$ \\
\hline & TAN & 629 & 002 & Manually & $3.9 \mathrm{E}-02$ & 7.1E-04 \\
\hline & CFA & 662 & 011 & System & $1.0 \mathrm{E}-03$ & $6.7 \mathrm{E}-04$ \\
\hline & CFA & 688 & 043 & System & $8.0 \mathrm{E}-04$ & $2.4 \mathrm{E}-04$ \\
\hline & ANL & 768 & 027 & System & $2.7 \mathrm{E}-02$ & $2.0 \mathrm{E}-04$ \\
\hline & TAN & 679 & 027 & Manually & $2.5 \mathrm{E}-04$ & $1.8 \mathrm{E}-04$ \\
\hline & TAN & 679 & 026 & Manually & $2.5 \mathrm{E}-04$ & $1.8 \mathrm{E}-04$ \\
\hline & TAN & 679 & 025 & Manually & $2.5 \mathrm{E}-04$ & $1.8 \mathrm{E}-04$ \\
\hline & $\mathrm{CPP}$ & 637 & 058 & Manually & $2.0 \mathrm{E}-03$ & $1.0 \mathrm{E}-04$ \\
\hline & TAN & 607 & 039 & Manually & $3.9 \mathrm{E}-02$ & $7.0 \mathrm{E}-05$ \\
\hline & ANL & 753 & 029 & Manually & $5.0 \mathrm{E}-02$ & $3.0 \mathrm{E}-05$ \\
\hline & TAN & 603 & 028 & System & $1.6 \mathrm{E}-02$ & $2.0 \mathrm{E}-05$ \\
\hline & TAN & 679 & 067 & System & $1.2 \mathrm{E}-02$ & $1.0 \mathrm{E}-05$ \\
\hline & TAN & 641 & 035 & System & $1.4 \mathrm{E}-03$ & $0.0 E+00$ \\
\hline & PER & 613 & 009 & System & $1.4 \mathrm{E}-03$ & $0.0 \mathrm{E}+00$ \\
\hline & $\mathrm{CPP}$ & 606 & 019 & Manually & $0.0 \mathrm{E}+00$ & $0.0 E+00$ \\
\hline & TAN & 603 & 022 & System & 2.7E-02 & $0.0 \mathrm{E}+00$ \\
\hline & NRF & 620 & 013 & Manually & $0.0 \mathrm{E}+00$ & $0.0 \mathrm{E}+00$ \\
\hline & NRF & 620 & 014 & Manually & $0.0 \mathrm{E}+00$ & $0.0 \mathrm{E}+00$ \\
\hline & WMF & GRP & 001 & Manually & $0.0 E+00$ & $0.0 \mathrm{E}+00$ \\
\hline
\end{tabular}

* Hourly rates are only an approximation and assume that rates are additive. These rates may be skewed upward. 
Table 37. Small portable fuel burning equipment emissions from the INEEL for 1998.

\begin{tabular}{|c|c|c|c|}
\hline \multirow[b]{2}{*}{ Chemical } & \multicolumn{3}{|c|}{ Emissions } \\
\hline & $\mathrm{lb} / \mathrm{hr} *$ & $\operatorname{ton} / \mathrm{yr}$ & $\mathrm{lb} / \mathrm{yr}$ \\
\hline \multicolumn{4}{|l|}{ Primary pollutants } \\
\hline NOx & $2.5 \mathrm{E}+01$ & $6.4 \mathrm{E}+00$ & 12,896 \\
\hline $\mathrm{CO}$ & $5.3 \mathrm{E}+00$ & $1.4 \mathrm{E}+00$ & 2,779 \\
\hline VOCNM & $1.8 \mathrm{E}+00$ & $4.8 \mathrm{E}-01$ & 953 \\
\hline PM-10 & $1.8 \mathrm{E}+00$ & $4.6 \mathrm{E}-01$ & 915 \\
\hline SOx & $1.6 \mathrm{E}+00$ & 4.3E-01 & 853 \\
\hline \multicolumn{4}{|l|}{ Hazardous air pollutants } \\
\hline Propylene & $1.5 \mathrm{E}-02$ & $3.8 \mathrm{E}-03$ & 7.5 \\
\hline Formaldehyde & $6.6 \mathrm{E}-03$ & $1.7 \mathrm{E}-03$ & 3.4 \\
\hline Benzene & $5.2 \mathrm{E}-03$ & $1.4 \mathrm{E}-03$ & 2.7 \\
\hline Acetaldehyde & $4.3 \mathrm{E}-03$ & $1.1 \mathrm{E}-03$ & 2.2 \\
\hline Toluene & $2.3 E-03$ & $6.0 \mathrm{E}-04$ & 1.2 \\
\hline Xylene & $1.6 \mathrm{E}-03$ & 4.2E-04 & 0.83 \\
\hline Acrolein & $5.2 \mathrm{E}-04$ & $1.4 \mathrm{E}-04$ & 0.27 \\
\hline Naphthalene & 4.8E-04 & $1.2 \mathrm{E}-04$ & 0.25 \\
\hline 1,3-Butadiene & 2.2E-04 & 5.7E-05 & 0.11 \\
\hline Phenanthrene & $1.7 \mathrm{E}-04$ & $4.3 E-05$ & 0.086 \\
\hline Fluorene & $1.6 \mathrm{E}-04$ & 4.3E-05 & 0.085 \\
\hline Fluoranthene & 4.3E-05 & $1.1 \mathrm{E}-05$ & 0.022 \\
\hline Acenaphthylene & $2.8 \mathrm{E}-05$ & $7.4 \mathrm{E}-06$ & 0.015 \\
\hline Pyrene & $2.7 \mathrm{E}-05$ & $7.0 \mathrm{E}-06$ & 0.014 \\
\hline Anthracene & $1.1 \mathrm{E}-05$ & 2.7E-06 & 0.0055 \\
\hline Benzo anthracene & $9.4 \mathrm{E}-06$ & $2.5 \mathrm{E}-06$ & 0.0049 \\
\hline Acenaphthene & $8.0 \mathrm{E}-06$ & 2.1E-06 & 0.0042 \\
\hline Dibenz anthracene & $3.3 \mathrm{E}-06$ & $8.5 E-07$ & 0.0017 \\
\hline Benzo(g,h,l)perylene & $2.7 \mathrm{E}-06$ & $7.1 \mathrm{E}-07$ & 0.0014 \\
\hline Indeno $(1,2,3)$ pyrene & $2.1 E-06$ & $5.5 \mathrm{E}-07$ & 0.0011 \\
\hline Chrysene & $2.0 \mathrm{E}-06$ & $5.2 \mathrm{E}-07$ & 0.0010 \\
\hline Benzo fluoranthene & $1.4 \mathrm{E}-06$ & $3.7 \mathrm{E}-07$ & 0.00074 \\
\hline Benzo pyrene & $1.1 E-06$ & 2.7E-07 & 0.00055 \\
\hline
\end{tabular}

* Assumes all portable fuel burning equipment are running at the same time. 


\section{GRAPHICS FOR INEEL EMISSION DATA}

The data presented in section 5 has been graphed in this section. The principle air pollutants are measured in tons. The remaining emissions are measured in pounds. Care need to be takes when going from graph to graph because the scale of the graphs change. This is because emissions rang from many tons for the primary chemicals down to a thousands of a pound.

\subsection{Listing of Emission Graphics}

The following graphs provide perspective on air releases at the INEEL for 1998.

- Figure 21. Emissions from the INEEL over 2 tons for 1998 (tons).

- Figure 22. Emissions from the INEEL from 100 to 6,000 pounds.

- Figure 23. Emissions from the INEEL from 6 to 100 pounds.

- Figure 24. Emissions from the INEEL from 0.80 to 6 pounds.

- Figure 25. Emissions from the INEEL from 0.1 to 0.8 pound.

- Figure 26. Emissions from the INEEL from 0 to 0.1 pound.

- Figure 27. Metal emissions from the INEEL for 1998 (pounds).

- Figure 28. Emissions from small portable engines for 1998 (pounds). 


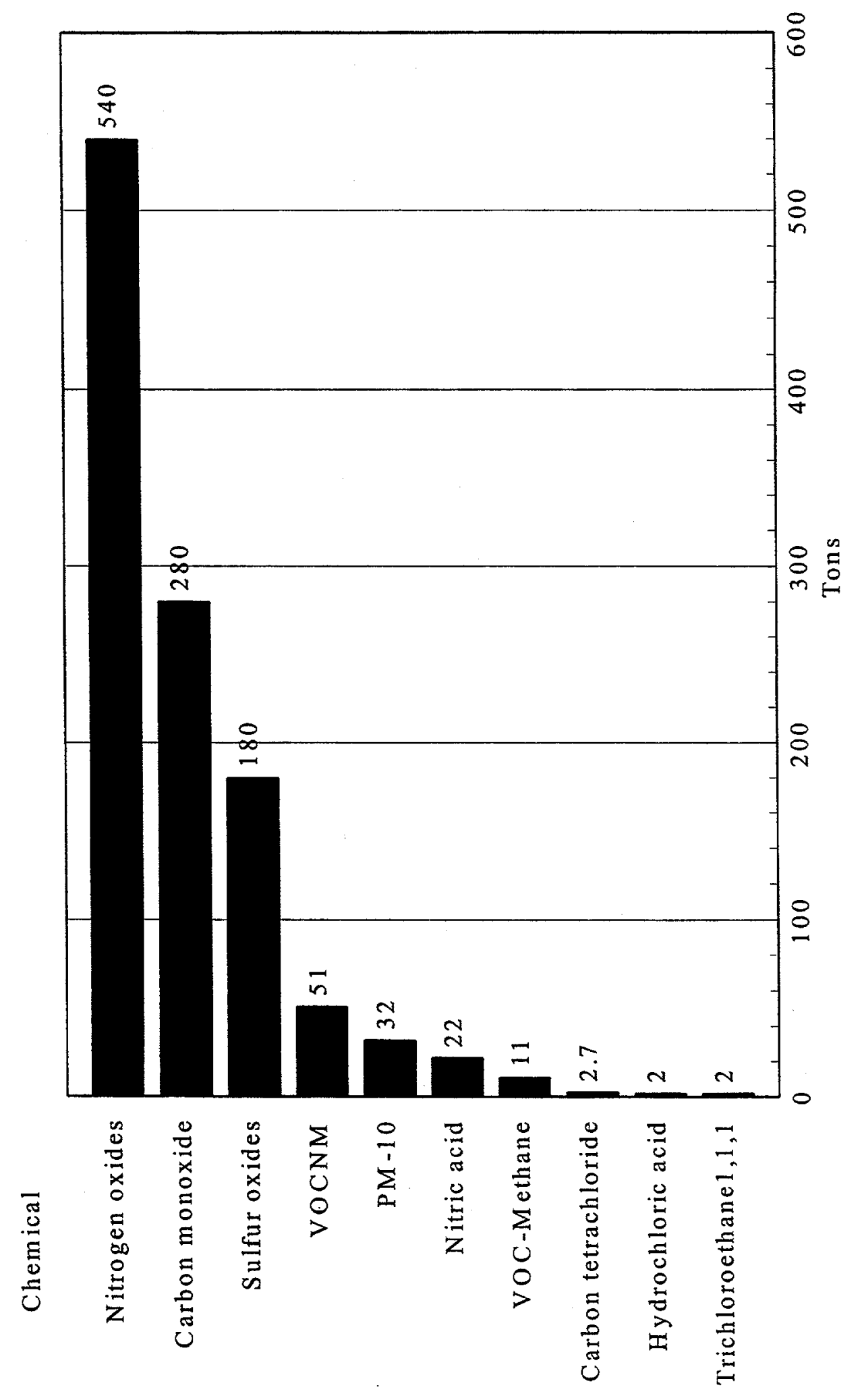

$\dddot{2}$

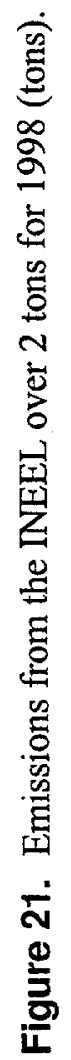




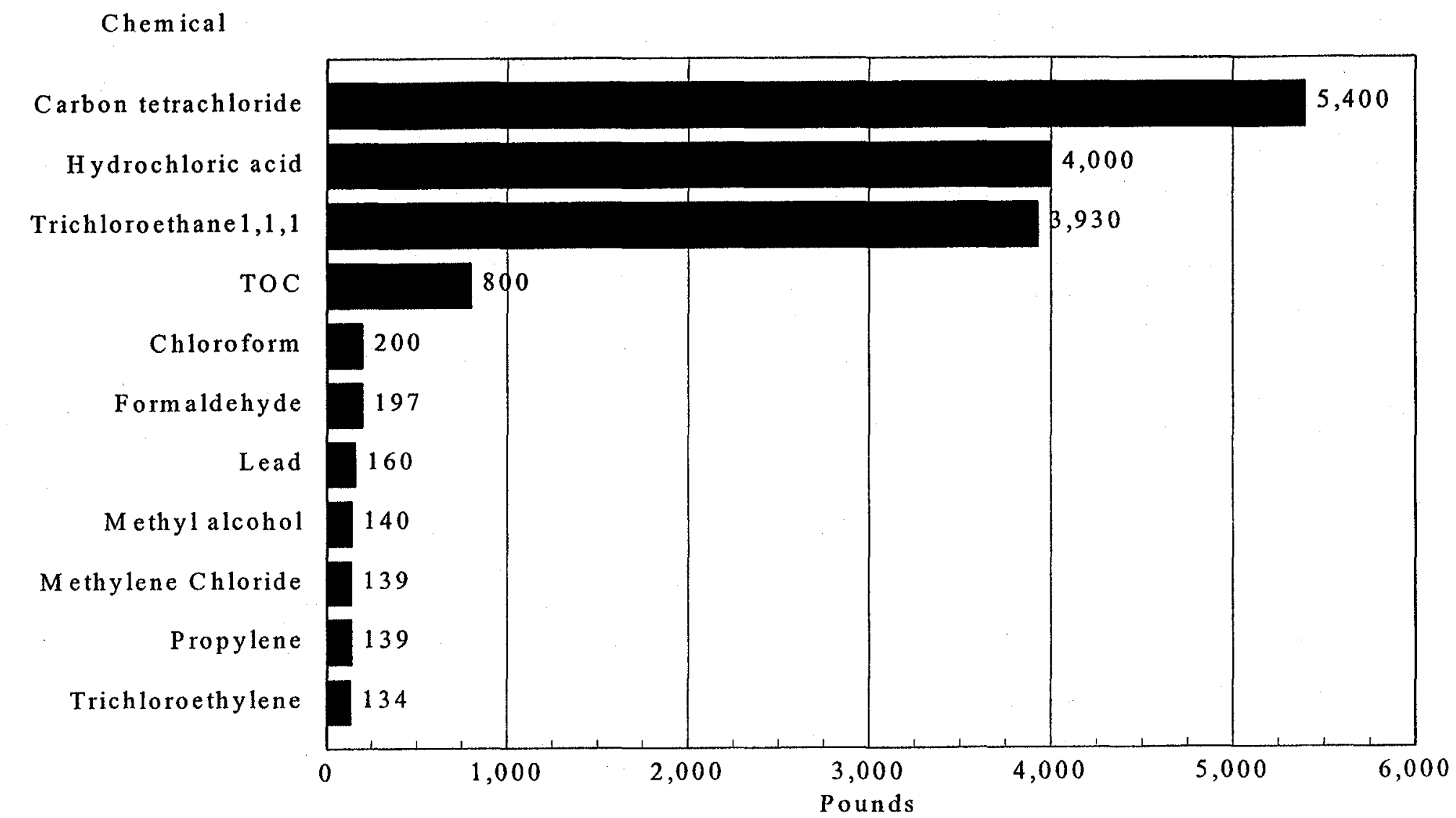

Figure 22. Emissions from the INEEL from 100 to 6,000 pounds. 


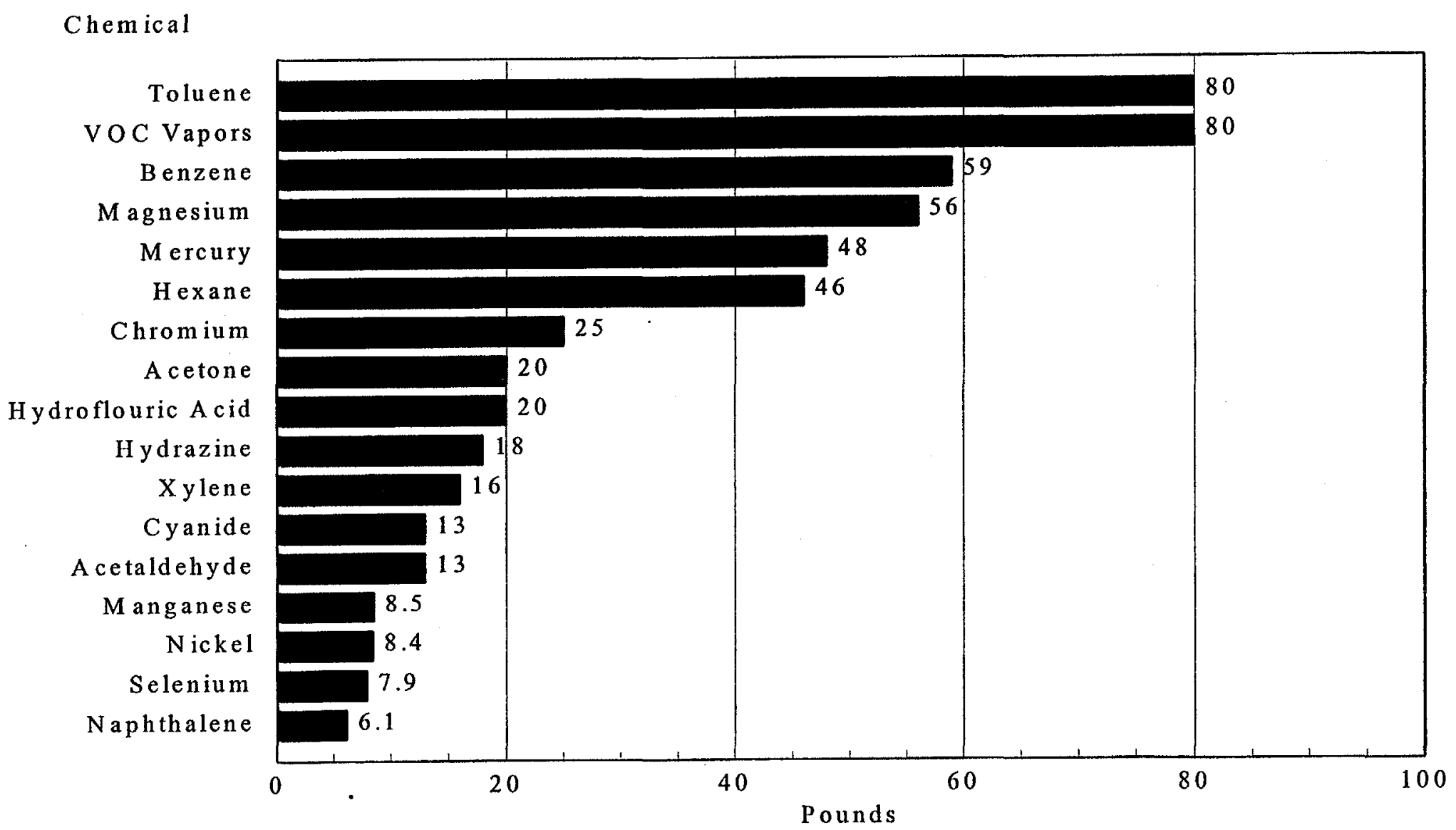

Figure 23. Emissions from the INEEL from 6 to 100 pounds. 


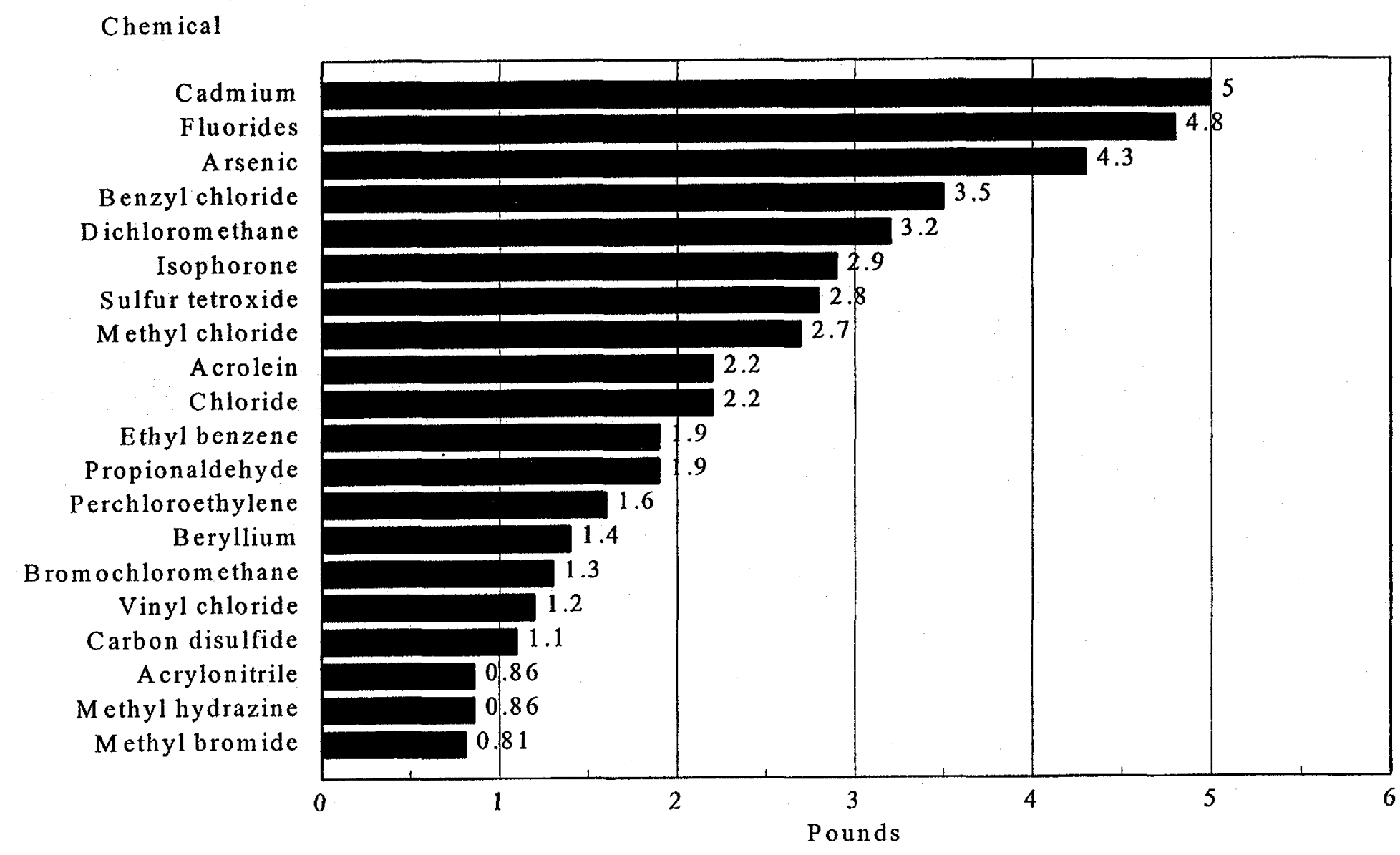

Figure 24. Emissions from the INEEL from 0.80 to 6 pounds. 

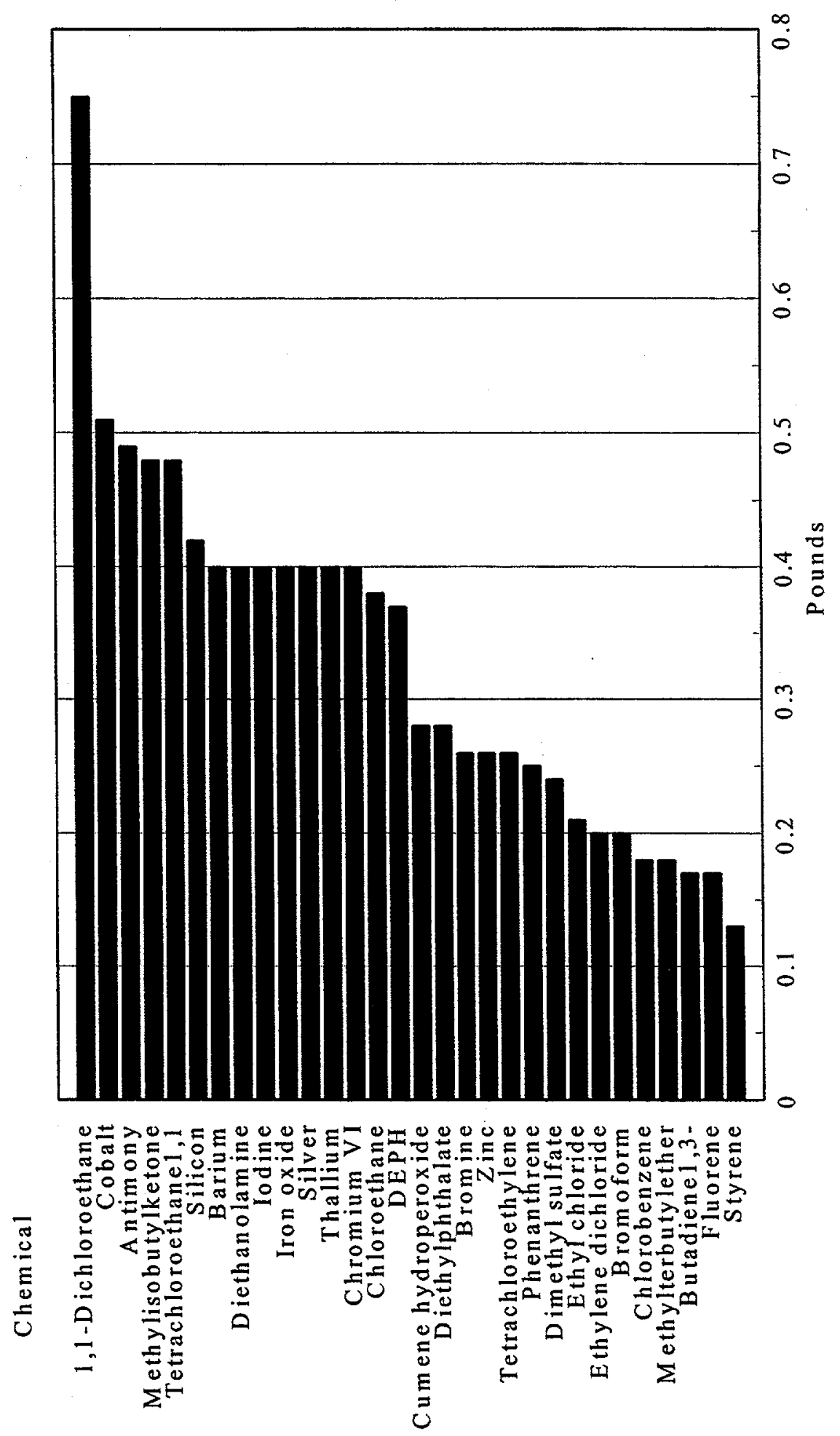
Chemical

Methyl methacrylate

Dichloroethane 1,2Phenol

Dichlorobenzene

Carbonyl sulfide

Acetophenone

Acenaphthene

Fluoranthene

Dichloropropane1,2Acenaphthylene

entachlor Pyrene

Vinyl acetate

Chloroacetophenone2-

Trichloroethane1 1

Cumene

Benzoanthracene Anthracene

Chrysene

Benzoperylene Biphenyl

Indeno $(1,2,3)$ pyrene

Benzofluoranthene

Dibenzanthracene Ethylene dibromide

Benzopyrene

Dinitrotoluene 2,4

Methyl chrysenes-

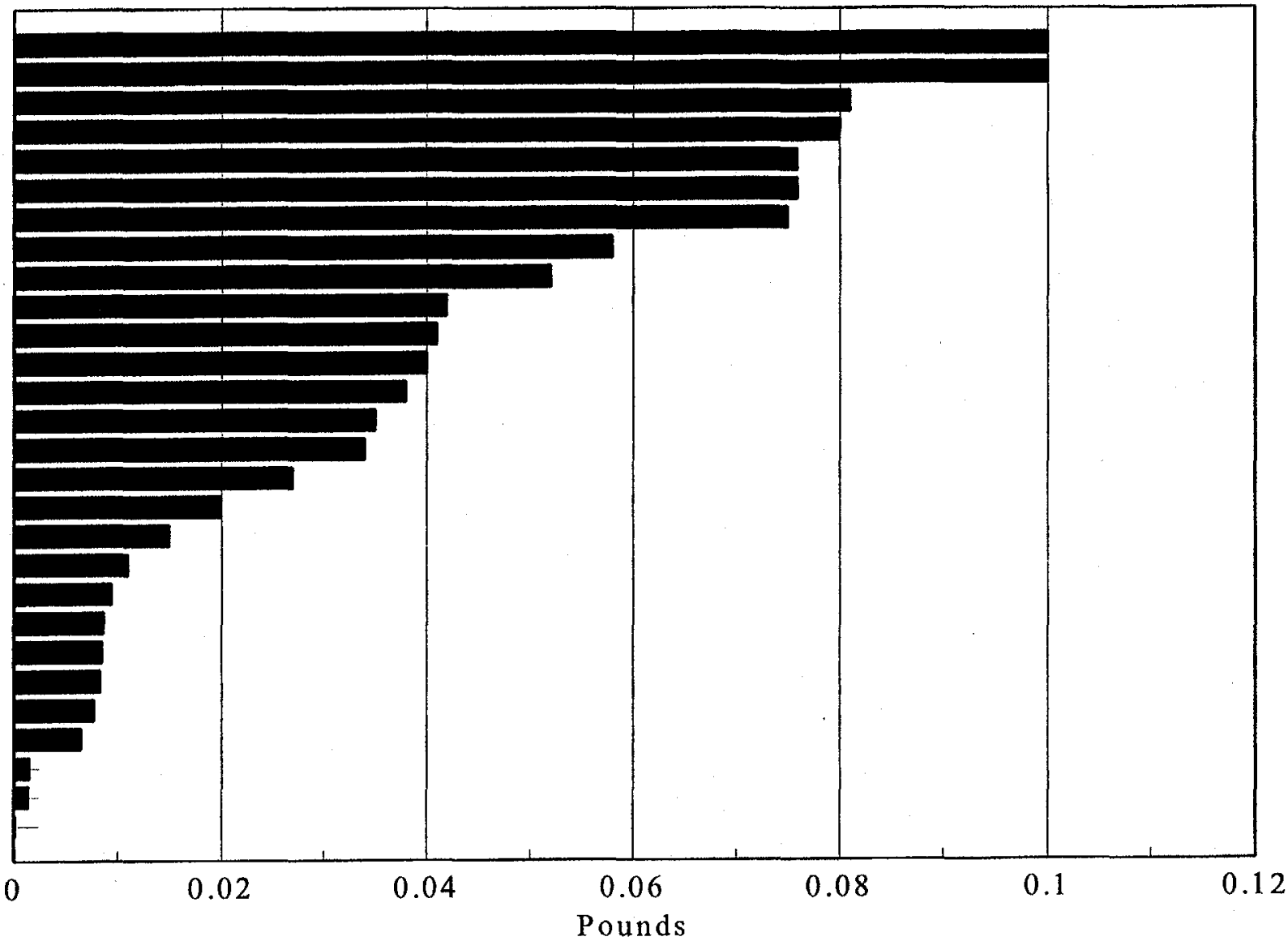

Figure 26. Emissions from the INEEL from 0 to 0.1 pound. 


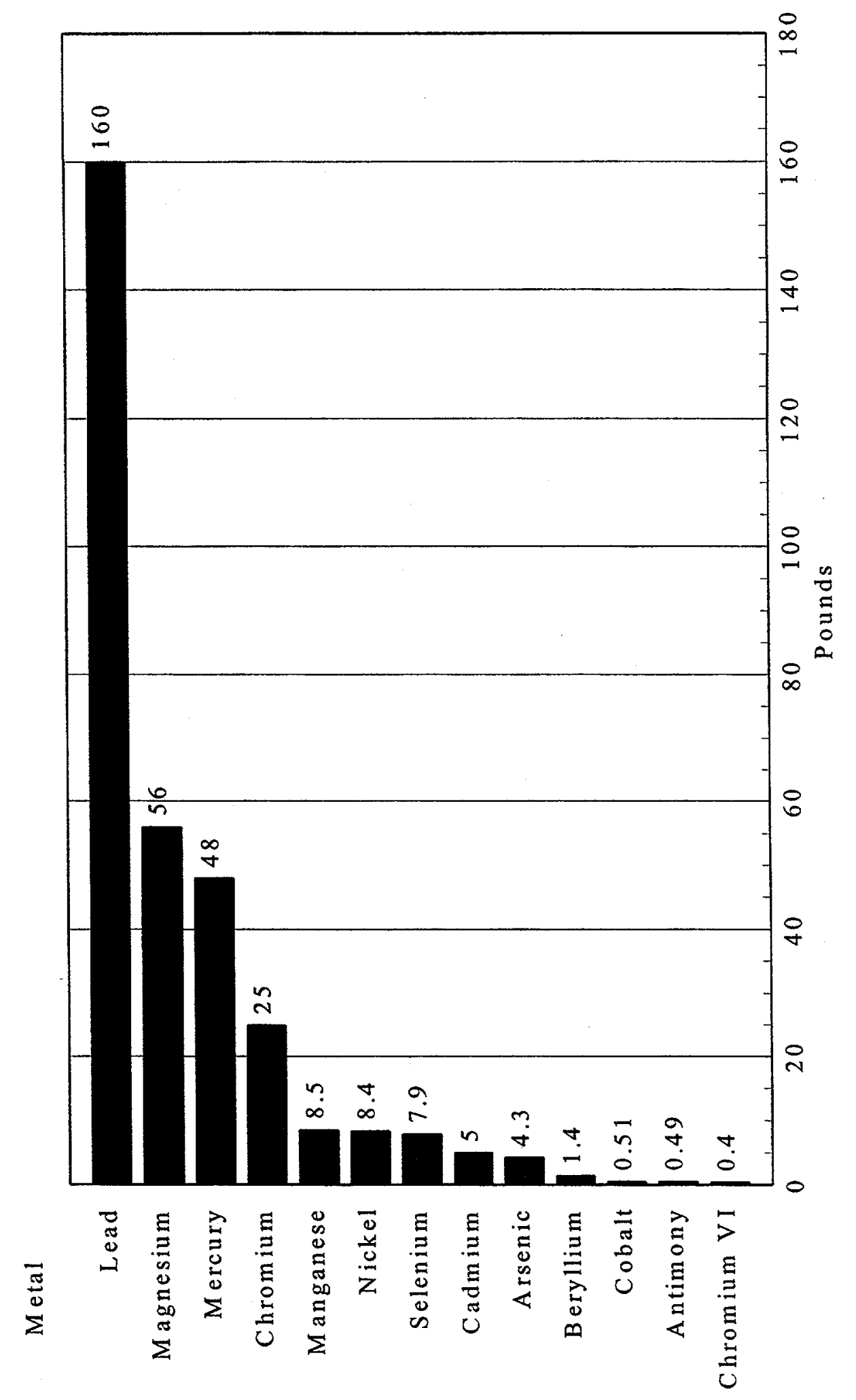




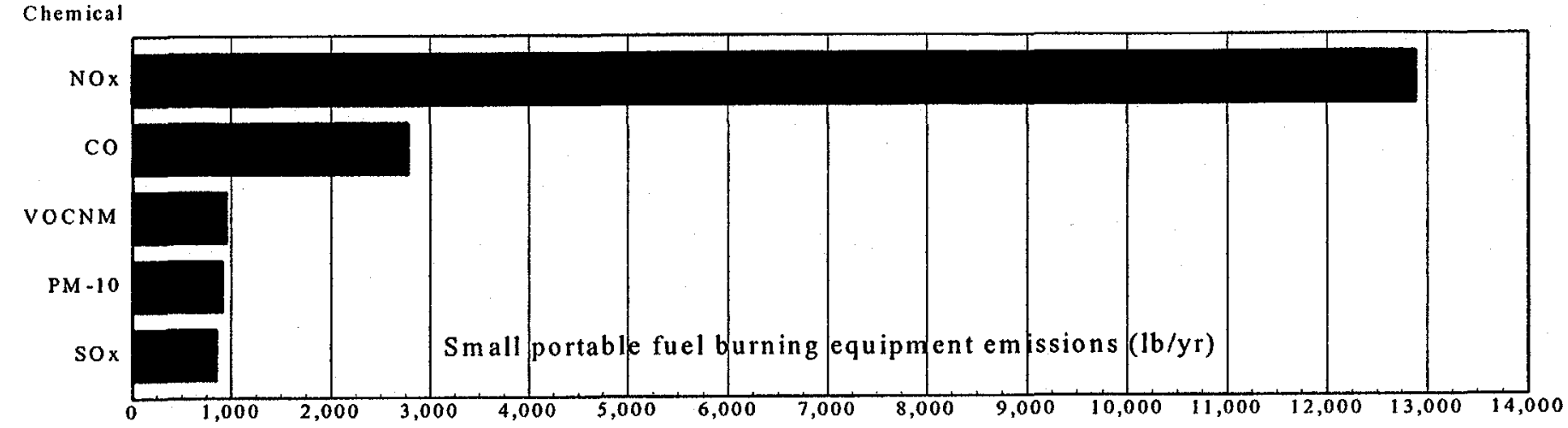

Chemical

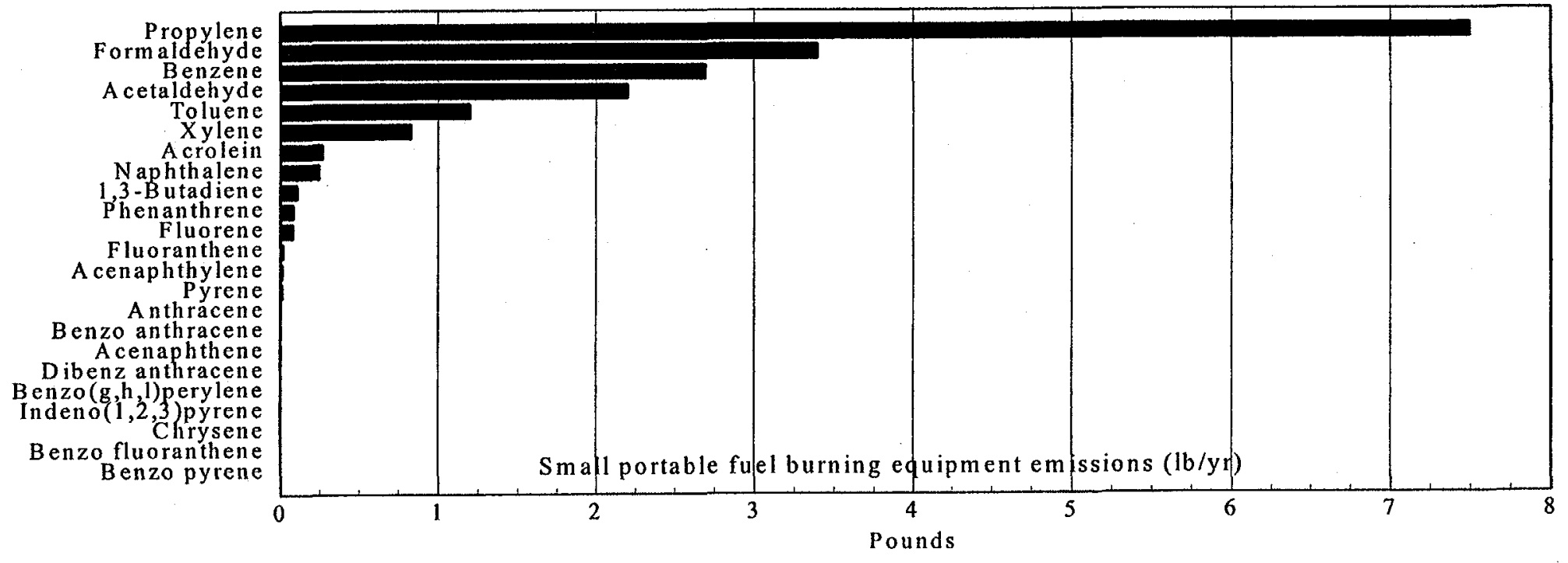

Figure 28. Emissions from small portable engines for 1998 (pounds). 


\section{REFERENCES}

DOE-ID, 1997, Air Emission Inventory for the Idaho National Engineering and Environmental Laboratory]1997 Emissions Report, U.S. Department of Energy, Field Office, Idaho, DOE/ID10646, June 1998.

DOE-ID, 1993, Idaho National Engineering Laboratory Technical Site Information, DOE/ID-10401, May 1993.

DOE-ID, 1992, Air Emission Inventory for the Idaho National Engineering LaboratoryD1990\& 1991 Emissions Report, U.S. Department of Energy, Field Office, Idaho, DOE/ID-10433(92), June 1992.

DOE-ID, 1991, Air Emission Inventory for the Idaho National Engineering Laboratory, DOE/ID-10432(91), March 1991.

DOE 1990, NESHAPs 40 CRF 61.93 Monitoring Requirements for Radiological Emission Sources at INEL, DOE/ID-10310, November 1990.

EPA, Compilation of Air Pollutant Emission Factors, U.S. Environmental Protection Agency, AP-42, $10 / 96$ edition..

EPA, Toxic Chemical Release Inventory Reporting Form, Form R, Section 313 of the Emergency Planning and Community Right-to-Know Act of 1986 (EPCRA), also known as Title III of the Superfund Amendments and Reauthorization Act (SARA); INEEL's 1998 Form R for Nitric Acid.

IDAPA 16.01.01.527, Idaho Administrative Procedures Act, Air Pollution Control

INEL 1995, Application for a Title V Operating Permit for the Idaho National Engineering Laboratory, INEL-95/0155-I through IX, July 1995.

Perry, R. H., and Green, D. W., Perry's Chemical Engineers' Handbook, Sixth Edition, McGraw-Hill, New York, NY, 1984.

Steven K Zohner letter to J. W. Gill, "1998 CFA Landfill Emissions Based On LandGEM 2.01 Computer Model - SKZ-08-98. 


\section{Appendix A}

Hazardous Air Pollutant List 


\section{Appendix A}

\section{Hazardous Air Pollutant List From the CAA With CAS \#}

This appendix contains the hazardous air pollutants listed alphabetically with CAS numbers. The list comes from the Clean Air Act. CAS numbers will be used in the future to help identify chemicals with complex names, multiple synonyms and spelling errors. This will increase the accuracy of the Air Emissions Inventory. 
Table A-1. Hazardous air pollutants from the Clean Air Act listed alphabetically.

\begin{tabular}{|c|c|c|c|c|c|}
\hline & CAS \# & Chemical & & CAS \# & Chemical \\
\hline 1 & $75-07-0$ & Acetaldehyde & 24 & $156-62-7$ & Calcium cyanamide \\
\hline 2 & $60-35-5$ & Acetamide & 25 & $105-60-2$ & Caprolactam \\
\hline 3 & $75-05-8$ & Acetonitrile & 26 & $133-06-2$ & Captan \\
\hline 4 & $98-86-2$ & Acetophenone & 27 & $63-25-2$ & Carbaryl \\
\hline 5 & $53-96-3$ & 2-Acetylaminofluorene & 28 & $75-15-0$ & Carbon disulfide \\
\hline 6 & $107-02-8$ & Acrolein & 29 & $56-23-5$ & Carbon tetrachloride \\
\hline 7 & $79-06-1$ & Acrylamide & 30 & $463-58-1$ & Carbonyl sulfide \\
\hline 8 & $79-10-7$ & Acrylic acid & 31 & $120-80-9$ & Catechol \\
\hline 9 & $107-13-1$ & Acrylonitrile & 32 & $133-90-4$ & Chloramben \\
\hline 10 & $107-05-1$ & Allyl chloride & 33 & $57-74-9$ & Chlordane \\
\hline 11 & $92-67-1$ & 4-Aminobiphenyl & 34 & $7782-50-5$ & Chlorine \\
\hline 12 & $62-53-3$ & Aniline & 35 & $79-11-8$ & Chloroacetic acid \\
\hline 13 & 90-04-0 & o-Anisidine & 36 & $532-27-4$ & 2-Chloroacetophenone \\
\hline 14 & $1332-21-4$ & Asbestos & 37 & $108-90-7$ & Chlorobenzene \\
\hline 15 & $71-43-2$ & Benzene (including benzene from gasoline) & 38 & $510-15-6$ & Chlorobenzilate \\
\hline 16 & $92-87-5$ & Benzidine & 39 & $67-66-3$ & Chloroform \\
\hline 17 & $98-07-7$ & Benzotrichloride & 40 & $107-30-2$ & Chloromethyl methyl ether \\
\hline 18 & $100-44-7$ & Benzyl chloride & 41 & $126-99-8$ & Chloroprene \\
\hline 19 & $92-52-4$ & Biphenyl : & 42 & $1319-77-3$ & Cresols/Cresylic acid (isomers and mixture) \\
\hline 20 & $117-81-7$ & Bis(2-ethylhexyl)phthalate (DEHP) & 43 & $95-48-7$ & o-Cresol \\
\hline 21 & $542-88-1$ & Bis(chloromethyl)ether & 44 & $108-39-4$ & m-Cresol \\
\hline 22 & $75-25-2$ & Bromoform & 45 & $106-44-5$ & p-Cresol \\
\hline 23 & $106-99-0$ & 1,3-Butadiene & 46 & $98-82-8$ & Cumene \\
\hline
\end{tabular}




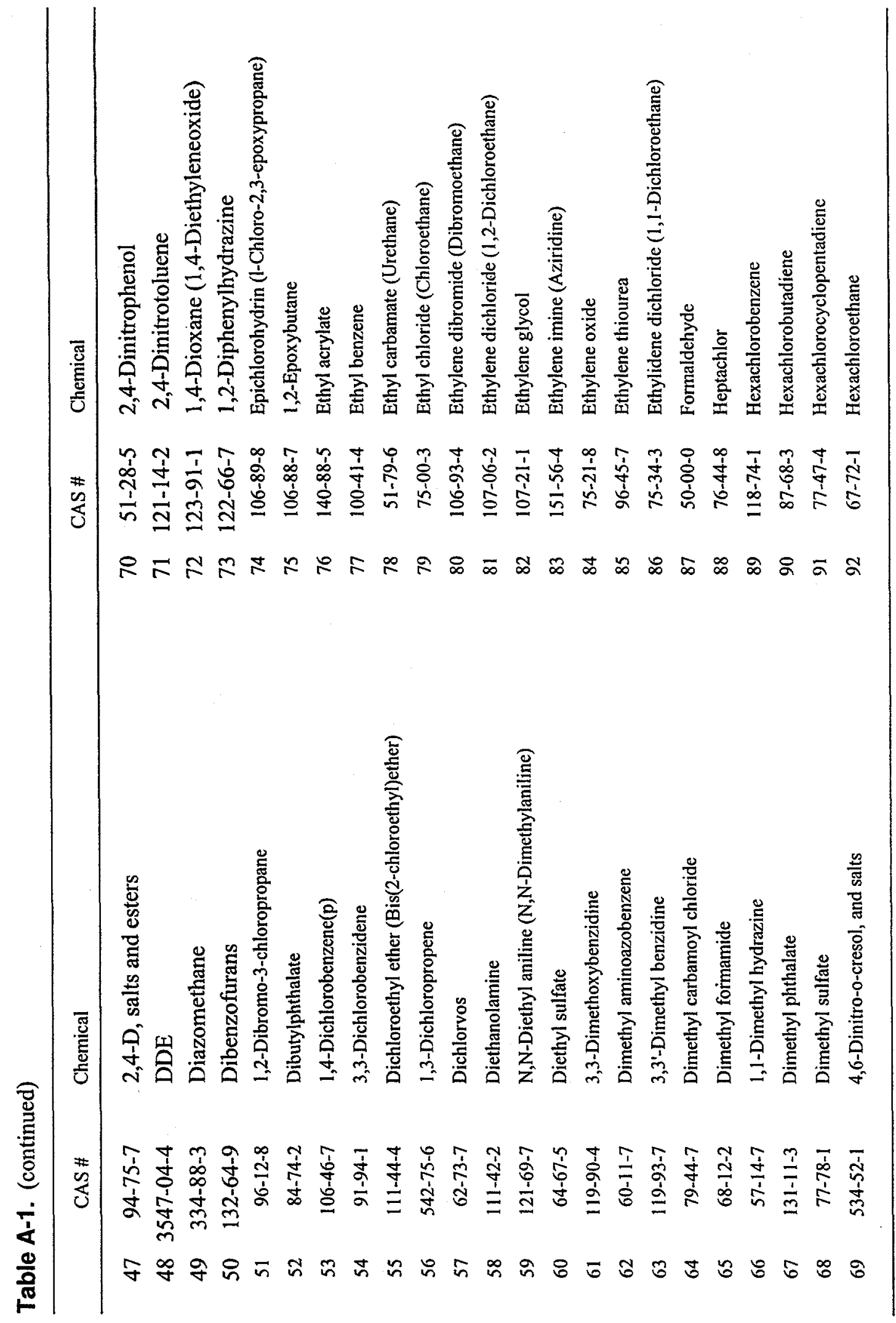


Table A-1. (continued)

\begin{tabular}{|c|c|c|c|c|c|}
\hline & CAS \# & Chemical & & CAS \# & Chemical \\
\hline 93 & $822-06-0$ & Hexamethylene-1,6-diisocyanate & 116 & $75-09-2$ & Methylene chloride (Dichloromethane) \\
\hline 94 & $680-31-9$ & Hexamethylphosphoramide & 117 & $101-68-8$ & Methylene diphenyl diisocyanate (MDI) \\
\hline 95 & $110-54-3$ & Hexane & 118 & $101-77-9$ & 4,4'-Methylenedianiline \\
\hline 96 & $302-01-2$ & Hydrazine & 119 & $91-20-3$ & Naphthalene \\
\hline 97 & $7647-01-0$ & Hydrochloric acid & 120 & $98-95-3$ & Nitrobenzene \\
\hline 98 & $7664-39-3$ & Hydrogen fluoride (Hydrofluoric acid) & 121 & $92-93-3$ & 4-Nitrobiphenyl \\
\hline 99 & $123-31-9$ & Hydroquinone & 122 & $100-02-7$ & 4-Nitrophenol \\
\hline 100 & $78-59-1$ & Isophorone & 123 & $79-46-9$ & 2-Nitropropane \\
\hline 101 & $58-89-9$ & Lindane (all isomers) & 124 & $684-93-5$ & $\mathrm{~N}$-Nitroso-N-methylurea \\
\hline 102 & $108-31-6$ & Maleic anhydride & 125 & $62-75-9$ & N-Nitrosodimethylamine \\
\hline 103 & $67-56-1$ & Methanol & 126 & $59-89-2$ & $\mathrm{~N}$-Nitrosomorpholine \\
\hline 104 & $72-43-5$ & Methoxychlor & 127 & $56-38-2$ & Parathion \\
\hline 105 & 74-83-9 & Methyl bromide (Bromomethane) & 128 & $82-68-8$ & Pentachloronitrobenzene (Quintobenzene) \\
\hline 106 & $74-87-3$ & Methyl chloride (Chloromethane) & 129 & $87-86-5$ & Pentachlorophenol \\
\hline 107 & $71-55-6$ & Methyl chloroform (1,1,1-Trichloroethane) & 130 & $108-95-2$ & Phenol \\
\hline 108 & $78-93-3$ & Methyl ethyl ketone (2-Butanone) & 131 & $106-50-3$ & p-Phenylenediamine \\
\hline 109 & $60-34-4$ & Methyl hydrazine & 132 & $75-44-5$ & Phosgene \\
\hline 110 & $74-88-4$ & Methyl iodide (Iodomethane) & 133 & $7803-51-2$ & Phosphine \\
\hline 111 & $108-10-1$ & Methyl isobutyl ketone (Hexone) & 134 & $7723-14-0$ & Phosphorus \\
\hline 112 & $624-83-9$ & Methyl isocyanate & 135 & $85-44-9$ & Phthalic anhydride \\
\hline 113 & $80-62-6$ & Methyl methacrylate & 136 & $1336-36-3$ & Polychlorinated biphenyls (Aroclors) \\
\hline 114 & $1634-04-4$ & Methyl tert butyl ether & 137 & $1120-71-4$ & 1,3-Propane sultone \\
\hline 115 & $101-14-4$ & 4,4-Methylene bis(2-chloroaniline) & 138 & $57-57-8$ & beta-Propiolactone \\
\hline
\end{tabular}


Table A-1. (continued)

\begin{tabular}{|c|c|c|c|c|c|}
\hline & CAS \# & Chemical & & CAS \# & Chemical \\
\hline 115 & $101-14-4$ & 4,4-Methylene bis(2-chloroaniline) & 138 & $57-57-8$ & beta-Propiolactone \\
\hline 139 & $123-38-6$ & Propionaldehyde & 162 & $121-44-8$ & Triethylamine \\
\hline 140 & $114-26-1$ & Propoxur (Baygon) & 163 & $1582-09-8$ & Trifluralin \\
\hline 141 & $78-87-5$ & Propylene dichloride (1,2-Dichloropropane) & 164 & $540-84-1$ & 2,2,4-Trimethylpentane \\
\hline 142 & $75-56-9$ & Propylene oxide & 165 & $108-05-4$ & Vinyl acetate \\
\hline 143 & $75-55-8$ & 1,2-Propylenimine (2-Methyl aziridine) & 166 & $593-60-2$ & Vinyl bromide \\
\hline 144 & $91-22-5$ & Quinoline & 167 & $75-01-4$ & Vinyl chloride \\
\hline 145 & $106-51-4$ & Quinone & 168 & $75-35-4$ & Vinylidene chloride (1,1-Dichloroethylene) \\
\hline 146 & $100-42-5$ & Styrene & 169 & $1330-20-7$ & Xylenes (isomers and mixture) \\
\hline 147 & $96-09-3$ & Styrene oxide & 170 & $95-47-6$ & o-Xylenes \\
\hline 148 & $1746-01-6$ & 2,3,7,8-Tetrachlorodibenzo-p-dioxin & 171 & $108-38-3$ & m-Xylenes \\
\hline 149 & $79-34-5$ & 1,1,2,2-Tetrachloroethane & 172 & $106-42-3$ & p-Xylenes \\
\hline 150 & $127-18-4$ & Tetrachloroethylene (Perchloroethylene) & & & \\
\hline 151 & $7550-45-0$ & Titanium tetrachloride & & & \\
\hline 152 & $108-88-3$ & Toluene & & & \\
\hline 153 & $95-80-7$ & 2,4-Toluene diamine & & & \\
\hline 154 & $584-84-9$ & 2,4-Toluene diisocyanate & & & \\
\hline 155 & $95-53-4$ & o-Toluidine & & & \\
\hline 156 & $8001-35-2$ & Toxaphene (chlorinated camphene) & & & \\
\hline 157 & $120-82-1$ & 1,2,4-Trichlorobenzene & & & \\
\hline 158 & $79-00-5$ & $79005 \ldots 1,1,2-$ Trichloroethane & & & \\
\hline 159 & $79-01-6$ & Trichloroethylene & & & \\
\hline 160 & $95-95-4$ & 2,4,5-Trichlorophenol & & & \\
\hline 161 & $88-06-2$ & 2,4,6-Trichlorophenol & & & \\
\hline
\end{tabular}


Table A-1. (continued)

\begin{tabular}{llllll}
\hline & CAS \# & Chemical & & CAS \# & Chemical \\
\hline 173 & 0 & Antimony Compounds & 182 & 0 & Lead Compounds \\
174 & 0 & Arsenic Compounds (inorganic including arsine) & 183 & 0 & Manganese Compounds \\
175 & 0 & Beryllium Compounds & 184 & 0 & Mercury Compounds \\
176 & 0 & Cadmium Compounds & 185 & 0 & Fine mineral fibers (3) \\
177 & 0 & Chromium Compounds & 186 & 0 & Nickel Compounds \\
178 & 0 & Cobalt Compounds & 187 & 0 & Polycylic Organic Matter (4) \\
179 & 0 & Coke Oven Emissions & 188 & 0 & Radionuclides (including radon) (5) \\
180 & 0 & Cyanide Compounds (1) & 189 & 0 & Selenium Compounds \\
181 & 0 & Glycol ethers (2) & & &
\end{tabular}

NOTE: For all listings above which contain the word "compounds" and for glycol ethers, the following applies: Unless otherwise specifies, these listings are defined as including any unique chemical substance that contains the named chemical (i.e. antimony) as part of that chemicals infrastructure.

(1) $\mathrm{X}^{\prime} \mathrm{CN}$ where $\mathrm{X}=\mathrm{H}^{\prime}$ or any other group where a formal dissociation may occur. For example $\mathrm{KCN}$

(2) Includes mono- and di- ethers of ethylene glycol, diethylene glycol, and triethylene glycol where

$\mathrm{n}=1,2$, or 3

$\mathrm{R}=$ alkyl or aryl groups

$\mathrm{R}^{\prime}=\mathrm{R}, \mathrm{H}$, or groups which, when removed, yield glycol ethers with the structure:

$\mathrm{R}-(\mathrm{OCH} 2 \mathrm{CH})<\mathrm{INF}>\mathrm{n}-\mathrm{OH}$. Polymers are excluded from the glycol category.

(3) Includes mineral fiber emissions from facilities manufacturing or processing glass, rock, or slag fibers.

(4) Includes organic compounds with more than one benzene ring, and which have a boiling point greater than or equal to $100 \mathrm{C}$.

(5) A type of atom which spontaneously undergoes radioactive decay. 